\title{
'Extracellular proteins from lignocellulose degrading Basidiomycetes: Redox enzymes from Trametes versicolor and Coprinopsis cinerea'
}

\author{
Dissertation \\ In Partial Fulfillment of the Requirements for the Degree \\ Doctor of Philosophy (PhD) \\ of the Faculty of Forest Sciences and Forest Ecology \\ Georg-August-University Göttingen
}

\author{
Submitted by \\ Ravi Chandra Dwivedi \\ Born in Chakhundi, India
}

Göttingen, January 2006 

$1^{\text {st }}$ Examiner : $\quad$ Prof. Dr. Ursula Kües

$2^{\text {nd }}$ Examiner : $\quad$ Prof. Dr. Reiner Finkeldey

$3^{\text {rd }}$ Examiner : $\quad$ Prof. Dr. Holger Militz

Date of Oral Examination: 21.02.2006 



\section{Zusammenfassung}

Das extrazelluläre Proteom bei Pilzen besteht aus drei Fraktionen: frei ins Medium ausgeschiedene Proteine, Proteine in der äußeren Schleimschicht der Hyphe und Zellwandproteine. Methoden zur Isolierung und Charakterisierung von sekretierten Enzymen von holz-abbauenden Basidiomyzeten einschließlich zellwandgebundenen Redox-Enzymen, insbesondere Laccasen, wurden etabliert bzw. optimiert. Bei Askomyzeten beschriebene Methoden zur Aufarbeitung von Zellwänden ließen sich bei Trametes versicolor nicht anwenden. Zerreiben von Myzel in einer Ballmühle mit Stahlkugel ergab reine Zellwände ohne Kontaminationen von zytoplasmischen Enzymen. Von Zellwänden isolierte Gesamtproteine lassen sich wie Proteine aus Kulturüberständen in 1D- und 2DElektrophorese analysieren und die Methode der Zellwandaufreinigung lässt sich auf andere Basidiomyzeten übertragen. Generell unterscheiden sich bei T. versicolor die drei Fraktionen von sekretierten Proteinen deutlich in Ladung und Größe. Von sieben Spots in 2D-Gelen des Kulturüberstandes wurden durch ESI-LC-MS-Analyse Peroxidasen und Laccase identifiziert, 90 andere Spots blieben unidentifiziert aufgrund fehlender Sequenzdaten.

In 1D- und 2D-Gelelektrophorese mit verschiedensten bekannten und neuen Substraten (allein, mit Co-Substraten und in Kombinationen) wurde das ins Medium ausgeschiedene Proteom von T. versicolor und Coprinopsis cinerea und auch das Zellwand-verbundene Proteom von T. versicolor auf Phenoloxidaseaktivitäten untersucht. Die Kombination TMA (N,N, $\mathrm{N}^{\prime}, \mathrm{N}^{\prime}$-Tetramethyl-1,4-phenylendiammoniumdichlorid) $+\alpha$-Naphthol war am sensitivsten im Erkennen von Phenoloxidaseaktivitäten, MBTH (3-Methyl-2benzothiazolinonhydrazonhydrochloridmonohydrat) + DHPPA (3,4-Dihydroxyhydrozimtsäure) ergab die schärfsten und stabilsten Banden und Spots in Gelen. Laccasen von T. versicolor and C. cinerea konnten durch ESI-LC-MS-Analysen in Banden identifiziert werden. Laccasen in T. versicolor Zellwänden wurden durch Behandlung mit verschiedenen lytischen Enzymen aus ihnen herausgelöst, in nativer PAGE aufgetrennt, Enzymgefärbt and Laccase III wurde identifiziert neben einer Pyranoseoxidase. Laccase III ist auch in hohen Konzentrationen in Kulturüberständen von T. versicolor nach Induktion durch 2,5-Xylidin vorhanden. Aufgereinigtes Enzym wurde in seinen Eigenschaften mit denen von Zellwand-gebundenen Laccaseaktivität verglichen. pH-Optima waren unterschiedlich und Stabilitäten in hohen Temperaturen und gegenüber Enzyminhibitoren sind bei gebundenen Enzymen besser. 



\section{Summary}

The work conducted during this thesis was aimed to study extracellular proteins from lignocellulose degrading Basidiomycetes including cell wall associated and fully secreted redox enzymes, especially laccases, from Trametes versicolor. Proteomic tools already established for yeasts and other ascomycetes could not be directly applied to study extracellular proteins from $T$. versicolor. Presence of high amounts of polysaccharids were limiting in protein precipitation and electrophoretic analysis. Therefore, available methods had to be tested, optimized and established for studies on this fungus.

Studies on cell wall enzymes require methods for preparation of pure cell wall fractions. Numerous cell breaking methods were described and applied for ascomycetes and for some basidiomycetes. However, their application on mycelia of T. versicolor was not successful. In no case, mycelium could be fully disrupted and some methods such as using a bead beater resulted in protein denaturation. A novel, very efficient method for breaking of mycelia that delivers a cell wall fraction free from cytoplasmic contaminants was developed in this work. Mycelia from T. versicolor were ground in a stainless steel container with $20 \mathrm{~mm}$ in diameter stainless steel ball at a temperature of liquid nitrogen using a ball mill. Efficiency and quality of the cell wall fraction was proved by scanning electron microscopy and their purity was demonstrated by absence of cytosolic marker enzymes (glucose-6-phosphatase dehydrogenase, isocitrate dehydrogenase) and a mitochondrial marker enzyme (malate dehydrogenase). The final purified preparation of cell walls retained enzyme activities and the mechanical disruption of the samples at the temperature of liquid nitrogen guaranteed recovery of chemically unchanged cell wall proteins. Analysis of non-covalently bound proteins obtained from these preparations by 1D- and 2D-electrophoresis confirmed the suitability of this material for proteomic studies. The developed method is very universal and can be applied to all higher basidiomycetes as shown here also for Pleurotus ostreatus.

Optimized methods of 1D- and 2D-native polyacrylamide gelectrophoresis (PAGE) were applied for separation of supernatant proteins from liquid cultures of the two basidiomycetes Coprinopsis cinerea and T. versicolor (after induction by copper and 2,5xylidine, respectively). Detection of phenoloxidases (PO's) was performed by in-gel staining of PO's. Several previously described staining methods for detection of PO's from different organisms were compared with each other for their application for $T$. versicolor and $C$. cinereus. Enzyme substrates, coreactants and combination of these 
substrates and coreactants were used to detect enzyme activities in 1D and 2Delectrophoresis after formation of coloured products upon PO's oxidations. The most sensitive staining was found to be a combination of TMA ( $N, N_{,}, N^{\prime}, N^{\prime}$-tetramethyl-1,4phenylenediammonium dichloride) and $\alpha$-naphthol, which could also detect maximum numbers of PO's bands in 1D-gels. Analysis of the stained PO's activities after tryptic digestion of proteins and LC-ESI-MS analysis of peptides allowed identification of Lcc1, Lcc10 and Lcc14 from C. cinerea and Laccase III from T. versicolor. The above staining method was very useful for detection of low enzyme activity and was also applied for ingel staining in 2D-electrophoresis. However, colored products produced by oxidation of TMA $+\alpha$-naphthol by PO's are water soluble and diffuse very fast within the gel, resulting in unsharp bands, a problem that becomes very serious in isoelectric focusing (IEF) of PO's performed in 4\% PAGE. Therefore, another staining method using MBTH (3-methyl-2-benzothiazolinon-hydrazon-hydrochlorid monohydrat) + DHPPA (3,4-dihydroxyhydrocinnamic acid) producing a colored MBTH-quinone adduct during the enzymatic reaction was found to be more valuable if sharp, thin and multiple bands have to be detected or if the detection is performed in low density gels such as by IEF. The zymographic methods were applied for detection of PO's activities in supernatants of $T$. versicolor cultures and in cell wall extracts.

Studies of laccases localization by immuno-gold labelling performed previously revealed presence of laccases in cell wall structures of a number of basidiomycetes. So far, only a few studies reported the release of laccase from the cell wall of basidiomycetes, for example from Cryptococcus neoformans. In this study, laccases were detected in the mycelia of non-induced and 2,5-xylidine-induced cultures of $T$. versicolor by colorimetric methods. Cell walls obtained from fungal mycelia were subjected to treatment with various hydrolytic enzymes and reducing agents in different combinations. The cell wall-associated laccases from $T$. versicolor was finally released on large scale by fractionated extraction with hydrolytic enzymes: Trichoderma lysate, cellulase, and chitinase. Further, the released cell wall laccases were separated by native PAGE and at least two enzymes were identified through phenoloxidase staining in the gels. The major of the two enzymes was identified by ESI-LC-MS as containing laccase III whilst in a second band with phenoloxidase activity a pyronase activity was identified.

Laccase III present in high concentration in 2,5-xylidine induced liquid cultures of $T$. versicolor was concentrated on a preparative DEAE (diethylaminoethyl-dextran)-sepharose column and finally purified to homogeneity using a Mono-Q column as proved by SDS (sodium dodecyl-sulphate)-PAGE. The protein identity was confirmed after tryptic 
digestion and analysis by ESI-LC-MS. Laccase III in free and cell wall-associated form was characterized for its substrate activity towards ABTS (2,2'-azino-bis(3ethylbenzothiazoline-6-sulfonic acid), guaiacol, syringaldazin, and DMP at different $\mathrm{pH}$. The supernatant and cell wall associated laccases had different $\mathrm{pH}$-dependent activities towards all the tested substrates except for ABTS, for which both laccases had similar an activity between $\mathrm{pH}$ 4.0-5.0. The temperature optimum for cell wall-bound and the supernatant laccase was $40^{\circ} \mathrm{C}$ and $50^{\circ} \mathrm{C}$, respectively. The cell wall-associated laccase had a higher temperature stability, retaining about $75 \%$ of its activity after six hours of incubation at $50^{\circ} \mathrm{C}$ while the supernatant laccase lost nearly $50 \%$ of its activity under these conditions. The cell wall-associated laccase was also more resistant to inhibition by $\mathrm{NaN}_{3}, \mathrm{NaF}$, and EDTA (ethylenediamine tetra-acetic acid) as compared to the supernatant laccase which was highly susceptible to inhibition by even low concentrations of inhibitors.

The extracellular proteome of $T$. versicolor comprises of three fractions: supernatant proteins, hyphal sheath associated proteins and cell wall-associated proteins (noncovalently and covalently bound). After adaptation of protocols for protein precipitation, protein loading amount, iso-electric focusing, staining sensitivity and compatibility for ESI-LC-MS analysis, in-gel digestion protocols, and mass spectrometry parameters for studies of $T$. versicolor proteome, three fractions of non-covalently bound proteins were analyzed by 1D- and 2D-electrophoresis. Each of the three protein fractions revealed a unique protein profile differing in molecular weight and pI values. 97 visible spots obtained after 2D-electrophoresis from culture supernatant proteins were analyzed by ESI-LC-MS. Identified proteins were enzymes mainly involved in lignolignolytic process: manganese peroxidase, manganese-repressed peroxidase, lignin peroxidase, and laccase. Due to lack of genomic data for T. versicolor most of the protein spots (90) could not be identified. Availability of genomic or EST-data for T. versicolor is necessary for further progress in studies on proteome of this white rot basidiomycete and a better understanding of the wood degradation processes. 



\section{Acknowledgement}

It is my privilege to express my gratitude to Prof. Dr. Ursula Kües for giving me an excellent $\mathrm{PhD}$ project to work on. Her mentorship and encouragement developed a sense of self-confidence and independent thinking in me during course of the present work.

I am greatly thankful to Dr. Andrzej Majcherczyk for his constant supervision, suggestions and critics. He helped me in getting familiar with the protein work. His encouragement, discussions and guidance have been extremely useful during my work. I am delighted to thank Mr. Mojtaba Zomorrodi who introduced me to the lab, provided initial help in performing 2D-electrophoresis and related proteomics work. He was always available to help me.

I am also thankful to Dr. Patrik Hoegger for his support during my stay in the lab. I extend special thanks to Dr. Oliver Valerius from the Institut für Mikrobiologie und Genetik, Göttingen for his help in scanning the 2D-gels and familiarizing me with PDQUEST $^{\mathrm{TM}}$ analysis.

Thanks to all my colleagues Prayook, Rajesh, Sreedhar, Sudhakar, Kalyani, Martin, Wassana, Ihtzaz, Constanza, Christa in the department and the institute for all their help and creating a professional environment at work.

I would like to thank Frau Marianne for providing clean glassware that I used for my experiments.

I express my gratitude to all those people who made a difference in my life in these years by their special ways. I can never forget Frau Lange and her family, Herr. Kopka, Monica, Tanja, Katka and Dr. Sharma for selflessly providing me everything I needed and requested for.

I wish to extend heartfelt gratitude to my friends Sanjay, Khalid, Pankaj, Anis, Ajay, Dilip, Kamal, Rebbecca, and Rajshree for creating a homely environment and timely help.

Above all, I am deeply grateful to my mother Smt. Prassanalata Dwivedi, father Dr. Umesh Chandra Dwivedi, brother Dr. Raghav Chandra Dwivedi and sister Pratima 
Dwivedi and my fiancée Namita Kanwar for their well wishes, affection, moral support and constant encouragement.

Thanks to all the people involved in our international PhD program from Georg-AugustUniversität, Göttingen along with Dr. Kürsten and concerned staff members. I would like thank to Deutsche Bundesstiftung Umwelt (DBU) for providing financial support.

And before I finish I extend my sincere thanks to Deutschland and people of this country for accepting and providing me with all the needful. 


\section{Table of contents}

Zusammenfassung ___ I

Summary__ II

Acknowledgement__ V V

Table of contents __ VII

Abbreviations _ XI

List of chemicals___ XIII

1. Introduction

1.1 The fungal cell wall

1.2 Cell wall composition ( $\beta$ 1,3- and $\beta$ 1,6-glucan, chitin, others)

1.3 Structural organization of cell wall

1.4 Properties and function of the cell wall __ 6

1.5 Proteins and enzymes in the cell wall of ascomycetes__ 8

1.5.1 GPI-dependent cell wall proteins (GPI-CWPs) __ 9

1.5.2 Pir proteins (Pir-CWPs) __ 9

1.5.3. Enzymes in the cell wall ___ 11

1.5.3.1 Enzymes associated with the cell wall ___ 11

1.5.3.2 The role of cell wall associated enzymes in filamentous fungi ___ 12

1.5.3.3 Attachment of WAEs to the cell wall ___ 12

1.6 Proteins and enzymes in the cell wall of basidiomycetes __ 13

1.7 Lignin degradation and enzymes __ 15

1.7.1 Degradation of lignocelluloses by white rot fungi __ 16

1.7.2 Lignin degrading enzymes of white rot fungi __ 16

1.7.2.1 Laccases___ 16

1.7.2.2 Peroxidases _ 18

1.7.2.3 Manganese dependent peroxidase __ 20

1.7.2.4 Manganese independent peroxidase ___ 21 
1.8 Extraction of cell wall associated proteins 22

1.9 Objective of the thesis 25

1.10 References 26

2. Disruption of cell walls and isolation of cell wall proteins from the white rot basidiomycete Trametes versicolor 41

2.1 Abstract 41

2.2 Introduction 41

2.3 Materials and methods 44

2.4 Result and Discussion 48

2.4.1 Establishing an efficient method for isolating highly purified CWF from fungal mycelium _ 48

2.4.2 The suitability of the purified CWF for proteomic analysis 52

2.4.3 Conclusion 53

2.5 References 54

3. Detection of phenol oxidising enzymes from higher basidiomycetes by native staining in 1D and 2D-gel electrophoresis with various phenols and aromatic amine substrates

3.1 Abstract 57

3.2 Introduction 57

3.3 Materials and methods 59

3.4 Result and discussion 62

3.4.1 In-gel detection of phenol oxidizing enzymes by various substrates 62

3.4.2 Identification of PO by ESI- LC-MS

3.4.3 Conclusion 76

3.5 References 76

4. Characterization and comparison of cell wall associated and secreted laccase from 2,5-xylidine induced cultures of Trametes versicolor 79 
4.1 Abstract 79

4.2 Introduction 79

4.3 Materials and methods 80

$\begin{array}{ll}\text { 4.4 Result and discussion } & 86\end{array}$

4.4.1 Stability test of supernatant activity ___ 86

4.4.2 Identification of the supernatant laccase __ 89

4.4.3 Cell wall associated laccase activity $\quad 90$

4.4.4 Characterization cell wall and supernatant laccase ___ 91

4.4.5 Conclusion__ 94

$\begin{array}{ll}\text { 4.5 References } & 95\end{array}$

5. Release of cell-wall associated laccases from T. versicolor __ 99

5.1 Abstract

5.2 Introduction

5.3 Materials and methods

5.4 Result and discussion $\quad 105$

5.4.1 Quantification of cell wall associated laccase during sample preparation ___ 105

5.4.2 Optimization of conditions for release of cell wall associated laccase by lytic enzymes __ 106

5.4.3 Effect of reducing agents on release of laccase from T. versicolor cell walls ___ 114

5.4.4 Protease contamination in lytic enzymes ___ 115

5.4.5 Effect of protease inhibitors on laccase activity ___ 116

5.4.6 Effects of higher cell wall sample amounts and different shaking parameters___ 118

5.4.7 A scaled up method for release of laccase from cell walls and identification by ESI-LC-MS 120

5.4.8 Comparision of total laccase activities in the supernatant and in cell walls of 2,5-xylidine-

induced T. versicolor cultures 123

5.4.9 Conclusion 125

5.5 References__ 125

6. Extracellular proteins from Trametes versicolor _ 129

$\begin{array}{lr}6.1 \text { Abstract } & 129\end{array}$

6.2 Introduction 129

6.3 Materials and methods 
6.4 Result and discussion 134

6.4.1 Conclusion 141

6.5 References 141

7. General discussion and conclusion 144

7.1 References 155

Publications 159

Curriculum Vitae 161 


\section{Abbreviations}

\begin{tabular}{|c|c|}
\hline $\mathrm{AAO}$ & aryl alcohol oxidase \\
\hline $\mathrm{AAD}$ & aryl alcohol dehydrogenase \\
\hline ABTS & 2,2'-azino-bis(3-ethylbenzothiazoline-6-sulfonic acid) \\
\hline APS & Ammoniumperoxodisulphate \\
\hline BSA & bovine serum albumin \\
\hline BSM & basidiomycete medium \\
\hline BME & $\beta$-mercaptoethanol \\
\hline $\mathrm{CDH}$ & cellobiose dehydrogenase \\
\hline $\mathrm{CE}$ & Cellulase \\
\hline $\mathrm{CH}$ & Chitinase \\
\hline $\mathrm{CW}$ & cell wall \\
\hline CWF & cell wall fractions \\
\hline CB-buffer & cell breaking buffer \\
\hline CHAPS & 3-[(3-cholamidopropyl)dimethylammonio]-1-propanesulfonate \\
\hline $1 \mathrm{D}$ & one dimensional \\
\hline $2 \mathrm{D}$ & two dimensional \\
\hline DTT & Dithiothreitol \\
\hline DMP & 2,6-dimethoxyphenol \\
\hline DAN & 1,8-diaminonaphthalene \\
\hline DMAB & 3-(dimethylamino)-benzoic acid \\
\hline DEAE & diethylaminoethyl-dextran \\
\hline DHPPA & 3,4-dihydroxyhydrocinnamic acid \\
\hline EDTA & ethylenediamine tetraacetic acid \\
\hline EDAX & energy-dispersive X-ray microanalysis \\
\hline $\mathrm{EtOH}$ & Ethanol \\
\hline ESI & electrospray ionization \\
\hline FPLC & fast protein liquid chromatography \\
\hline Fig. & Figure \\
\hline GOX & glyoxal oxidase \\
\hline G6PD & glucose-6-phosphatase dehydrogenase \\
\hline HEPES & $\mathrm{N}$-(2-hydroxyethyl)piperazine-N'-(2-ethanesulfonic acid) \\
\hline $\mathrm{ICD}$ & isocitrate Dehydrogenase \\
\hline IPG & immobilized $\mathrm{pH}$ gradient \\
\hline $\mathrm{kDa}$ & kilo dalton \\
\hline LA & Laminerase \\
\hline LC-MS & liquid chromatography mass spectrometry \\
\hline LiP & lignin peroxidase \\
\hline MBTH & 3-methyl-2-benzothiazolinon-hydrazon-hydrochlorid, monohydrat \\
\hline $\mathrm{MDH}$ & malate dehydrogenase \\
\hline $\mathrm{MnP}$ & manganese peroxidase \\
\hline MWCO & molecular cutoff \\
\hline $\mathrm{NaN}_{3}$ & sodium azide \\
\hline $\mathrm{NaF}$ & sodium fluoride \\
\hline NADH & nicotinamide adenine dinucleotide \\
\hline PAGE & polyacrylamide gel electrophoresis \\
\hline PMSF & Phenylmethylsulfonylflouoride \\
\hline PEB & protein extraction buffer \\
\hline PIC & protease inhibitor cocktail \\
\hline SB & Sample buffer \\
\hline SEM & scanning electron microscope \\
\hline
\end{tabular}




$\begin{array}{ll}\text { SDS } & \text { sodium dodecyl sulphate } \\ \text { Tris } & \text { tris-(dimethylamino)-methane } \\ \text { TCA } & \text { trichloroacetic acid } \\ \text { TEMED } & \text { tetramethyl-ethylenediamine } \\ \text { TMA } & \text { N,N,N'N'-tetramethyl-1,4-phenylenediammonium dichloride } \\ \text { TL } & \text { Trichoderma lysate } \\ \text { TCA } & \text { trichloroacetic acid } \\ \text { SGZ } & \text { Syringaldazine } \\ \text { SBI } & \text { soyabean inhibitor cocktail } \\ \text { UV } & \text { Ultraviolet } \\ \text { VA } & \text { veratryl alcohol } \\ \text { Vhr } & \text { volt hours } \\ \text { V } & \text { Volt } \\ \text { WAEs } & \text { wall associated enzymes } \\ \text { WAPs } & \text { wall associated proteins } \\ \varepsilon_{\lambda} & \text { absorption coefficient }\end{array}$

\section{Units}

$\begin{array}{ll}{ }^{\circ} \mathrm{C} & \text { degree celsius } \\ \mu \mathrm{g} & \text { Microgram } \\ \mu \mathrm{l} & \text { Microlitre } \\ \mu \mathrm{m} & \text { Micrometer } \\ \mu \mathrm{M} & \text { Micromolar } \\ \mathrm{aa} & \text { amino acid } \\ \mathrm{cm} & \text { Centimeter } \\ \mathrm{fmol} & \text { Femtomol } \\ \mathrm{g} & \text { gram (weight) } \\ \mathrm{h} & \text { Hour } \\ \mathrm{kDa} & \text { kilo dalton } \\ \mathrm{kV} & \text { kilo volt } \\ \mathrm{lit} & 1 \text { litre } \\ \mathrm{M} & \text { molar }(=\mathrm{mol} / \mathrm{l}) \\ \mathrm{mA} & \text { Milliampere } \\ \mathrm{mg} & \text { Milligram } \\ \mathrm{min} . & \text { Minute } \\ \mathrm{ml} & \text { Milliliter } \\ \mathrm{mm} & \text { Millimeter } \\ \mathrm{mM} & \text { Millimolar } \\ \mathrm{mol} & \text { Mole } \\ \mathrm{ng} & \text { nanogram } \\ \mathrm{nm} & \text { Nanometer } \\ \mathrm{pmol} & \text { Picomole } \\ \mathrm{rpm} & \text { rotations per minute } \\ \mathrm{v} / \mathrm{v} & \text { volume per volume } \\ \mathrm{w} / \mathrm{v} & \text { weight per volume }\end{array}$




\section{List of chemicals}

agar agar

ammoniumperoxodisulphate

[2,2'-azino-bis(3-ethylbenzothiazoline-6-sulfonic acid)]

antipanin

aprotonin

acrylamide

$\alpha$-naphthol

bromphenol blue

bovine serum albumin

cellulase

chitinase

coomassie plus protein assay reagent

$\mathrm{Ca}\left(\mathrm{NO}_{3}\right)_{2} \times 4 \mathrm{H}_{2} \mathrm{O}$

$\mathrm{CaCl}_{2}$

$\mathrm{CoCl}_{2} \times 6 \mathrm{H}_{2} \mathrm{O}$

$\mathrm{CuSO}_{4} \times 4 \mathrm{H}_{2} \mathrm{O}$

3,3-cholamidopropyldimethylammonio-1-propanesulfonate

2,6-dimethoxyphenol

1,8-diaminonaphthalene

3,4-dihydroxyhydrocinnamic acid

3-(dimethylamino)-benzoic acid

2,6-dimethoxyphenol

EDTA

$\mathrm{FeCl}_{3}$

glucose

glycerin

glycin

guaiacol

$\mathrm{H}_{2} \mathrm{O}_{2}(30 \%)$

$\mathrm{K}_{2} \mathrm{HPO}_{4}$

$\mathrm{KCl}$

$\mathrm{KH}_{2} \mathrm{PO}_{4}$

L-asparagin

L-lactate sodium salt

laminerase

$\mathrm{MgSO}_{4} \times 7 \mathrm{H}_{2} \mathrm{O}$

$\mathrm{MnSO}_{4} \times 4 \mathrm{H}_{2} \mathrm{O}$

3-methyl-2-benzothiazolinon-hydrazon-hydrochlorid $x \mathrm{H}_{2} \mathrm{O}$

$\mathrm{NaCl}$

$\mathrm{NaN}_{3}$

$\mathrm{NaF}$

$\mathrm{NH}_{4} \mathrm{NO}_{3}$

N,N,N`,N`-tetramethyl-1,4-phenylenediammonium dichloride phenylmethylsulfonylflouoride

pyrogallol

protease inhibitor cocktail

quantazyme

syringaldazine

sodium acetate

Trichoderma lysate
Serva, Germany

Fluka, Germany

Roche, Mannheim, Germany

Sigma, Germany

Sigma, Germany

Biomol, Germany

Merck, Germany

Fluka, Germany

Sigma, Germany

Merck, Germany

Sigma, Germany

Pierce, Rockford USA

Merck, Germany

Merck, Germany

Merck, Germany

Merck, Germany

Sigma, Germany

Sigma, Germany

Fluka, Germany

Aldrich, Germany

Fluka, Germany

Aldrich ,Germany

Sigma, Germany

Merck, Darmstadt

Merck, Darmstadt

Merck, Darmstadt

Promega, Germany

Fluka, Germany

Merck, Germany

Merck, Germany

Merck, Germany

Merck, Germany

Merck, Germany

Fluka, Germany

Sigma, Germany

Merck, Germany

Merck, Germany

Fluka, Germany

Riedel de Haen, Seelze

Sigma, Germany

Sigma, Germany

Merck, Germany

Merck, Germany

Sigma, Germany

Merck, Germany

Sigma, Germany

Qbiogene, Germany

Sigma, Germany

Merck, Germany

Serva, Germany 
tetramethyl ethylenediamine

tris- $\mathrm{HCl}$

tris-BASE

yeast extract

$\mathrm{ZnSO}_{4} \times 7 \mathrm{H}_{2} \mathrm{O}$
Fluka, Germany

Merck, Darmstadt

Promega, Germany

Oxoid, Germany

Merck, Germany 


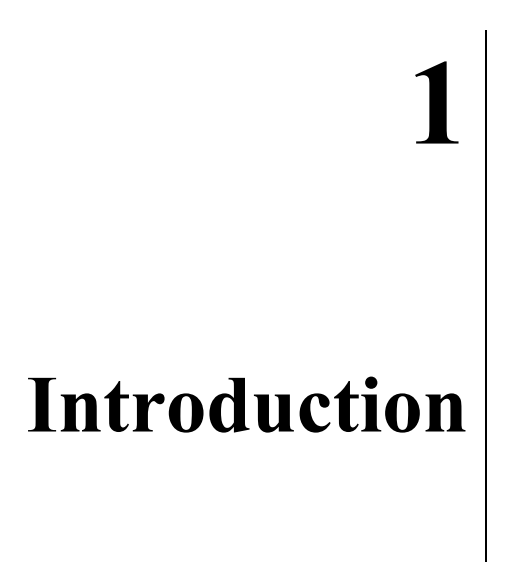





\section{Introduction}

\subsection{The fungal cell wall}

Fungi can occupy any habitat that offers adequate moisture, temperature and organic substrates. A fungal cell is constantly exposed to changing environments and is responsive to the external stimuli for its growth and survival. In order to maintain its structural integrity, be able to survive any inhospitable conditions and successfully interact with the surroundings, a fungal cell is surrounded on the outside by a highly elastic and robust structure called the fungal cell wall.

The most apparent function of the cell wall is that of protecting the cell against osmotic, physical, chemical and biological injury (Smith et al. 2000). Initially, the cell wall was considered to be an inert structure merely meant for providing rigidity and protection to the cell (Chaffin et al. 1998). Therefore, analysing the cell wall was long of not much interest to the researchers. However, in the recent year's research in fungal cell wall has gained an importance and the most important reason being successful integration of better biochemical, biophysical and molecular genetic techniques in cell wall research. Owing to the widening interest in this field, various groups have carried out detail studies on the cell wall structure. These studies have established that the cell wall is not just an inert structure but a robust, highly elastic and permeable structure essential to every aspect of fungal cell biology (Cabib et al. 1988; Gooday 1995; Sietsma and Wessels 2006; Latgé and Calderone 2006). It is now well known that the cell wall is involved in many processes such as growth and morphogenesis, interactions with the surrounding environment, cell-adhesion and cell-cell interaction (Gooday 1995; Smith et al. 2000).

Most of the studies involved in understanding the fungal cell wall were performed on Saccharomyces cerevisiae, Candida albicans and Aspergillus species. S. cerevisiae is however most widely used as the model system for structural, compositional and architectural studies of the cell wall. In fact, the knowledge on basic fungal cell wall structure is almost entirely based on the studies done on S. cerevisiae. A close 
comparison of the cell wall of S. cerevisiae with other related species such as C. albicans and Aspergillus shows that there is a striking similarity between the basic structure of the cells wall of these fungi (Chaffin et al. 1998; Klis et al. 2002). However, there are also important differences in cell walls of yeast and filamentous fungi. For example the amount of chitin present in the cell wall of $S$. cerevisiae and Aspergillus phoenics accounts for 2 and $23.7 \%$ of their dry weight respectively (Wessels and Sietsma 1979; Ruiz-Herrera 1992; Klis et al. 1997).

Studies elucidating cell walls in basidiomycetes are still in their infancy, with a few papers providing details of cell wall composition in Schizophyllum commune (Wessels et al. 1979). This calls for a need to expand on the existing understanding especially of basidiomycetes cell walls and is the purpose underlying this thesis.

\subsection{Cell wall composition ( $\beta$ 1,3- and $\beta$ 1,6-glucan, chitin, others)}

Studies performed on S. cerevisiae show that the primary constituents of a fungal cell wall are polysaccharides, namely B-glucans, and proteins complexed with polymers of mannose called mannoproteins (Table 1). In addition to this, there are small amounts of chitin and lipids present in the yeast cell wall. Carbohydrates in the form of glucans are the major most constituent of the cell wall material and often amount to a range of 80 to $90 \%$ of the cell wall dry weight (Ruiz-Herrera 1992; Latgé et al. 2006). While proteins and lipids are normally minor components of the cell wall, their amounts ranging from 3 to $20 \%$ and 1 to $10 \%$ of the cell wall dry weight, respectively, although some exceptions exist (Ruiz-Herrera 1992).

Table 1. Cell wall components of S. cerevisiae (after Klis et al. 1997)

\begin{tabular}{lcccc}
\hline Components & $\begin{array}{c}\text { Dry } \\
\text { Weight } \\
\text { \% }\end{array}$ & $\begin{array}{c}\text { Major glycosidic } \\
\text { linkages }\end{array}$ & $\begin{array}{c}\text { Degree of } \\
\text { polymerization }\end{array}$ & $\begin{array}{c}\mathbf{1 0}^{-6} \mathbf{x ~ M o l . ~} \\
\text { per cell }\end{array}$ \\
\hline Mannoproteins & 40 & $\alpha 1,6+\alpha 1,2+\alpha 1,3$ & - & 6.5 \\
ß1,6-Glucan & 5 & $\beta 1,6+$ some $\beta 1,3$ & 140 & 6.6 \\
Alkali-soluble $\beta 1,3-G l u c a n$ & 20 & $\beta 1,3+$ some $\beta 1,6$ & 1500 & 2.5 \\
Alkali-insoluble ß1,3-Glucan & 35 & $\beta 1,3+$ some $\beta 1,6$ & 1500 & 4.3 \\
Chitin & 2 & $\beta 1,4$ & 100 & 2.9 \\
\hline
\end{tabular}


In most fungi, the major polysaccharides of cell wall are represented by three basic constituents:

i. $\quad$-glucans, branched polymers of glucose containing $\beta-1,3$ and $\beta-1,6$ linkages

ii. Chitin, un-branched polymers of N-acetyl-D-glucosamine (GlcNAc) linked by $\beta$ 1,4 linkages and

iii. Polymers of mannose (mannans) covalently associated with proteins (glyco[manno]-proteins).

Microfibrillar polymers, namely $\beta$-glucans and chitin, form structural components of the cell wall, attributing to the rigid skeleton and strong physical properties. B-glucans are branched polymers and contribute the main portion to the cell wall dry weight. They are interwoven with chitin fibres forming the internal layer of the cell wall. In contrast, mannans (mannose polymers) do not exist as such in the cell wall but are covalently associated with proteins (mannoproteins) and form the outer cell wall layer (Ruiz-Herrera 1992; Kapteyn et al. 1997). The cell wall mannoproteins are most thoroughly investigated in S. cerevisiae and identical mannoproteins are found in C. albicans (Calderone et al. 1991). Mannose polymers are linked to the protein moiety through asparagine (by Nglycosidic bonds through two GlcNAc [di-N-acetylchitobiose] residues) and threonine or serine (by O-glycosidic, alkali-labile linkages) residues. The N-glycosidically linked carbohydrate is composed of backbone chains of $\beta-1,6$-linked mannopyranosyl residues to which oligosaccharide side chains are attached. The side chain mannopyranosyl residues contain $\beta-1,2, \beta-1,3, \beta-1,2, \beta-1,6$, and phosphodiester linkages as well as branches $(ß-1,6)$ that are over synthesized under acidic growth conditions (Kobayashi et al. 1992; Kobayashi et al. 1997). It is suggested that B-1,3- and ß-1,6-glucans are linked to proteins by phosphodiester linkages, a process that may involve the participation of a GPI (glycosyl phosphatidylinositol) anchor (Kapteyn et al. 1995). Interactions between glyco(manno)- proteins and chitin have been well documented in S. cerevisiae (Klis et al. 2002) and also appear to exist in the wall of C. albicans cells. This has been demonstrated by the following evidences (Elorza et al. 1987; Marcilla et al. 1991):

i. Chitinase treatment of isolated cell walls solubilizes protein moieties.

ii. The kinetics of incorporation of protein and mannoprotein constituents into the wall of regenerating protoplast is altered in the presence of nikkomycin, an antibiotic that blocks chitin synthesis. (Kollar et al. 1997; Kollar et al. 1995) 
Studies performed by Kollar et al. $(1995 ; 1997)$ detected the presence of all four major components, $\beta$-1,3-glucan, $\beta$-1,6-glucan, chitin, and mannoprotein in the cell wall of $S$. cerevisiae. Their analysis indicated that $\beta$-1,6-glucan has some $\beta$-1,3-glucan branches that may be linked to the reducing end of chitin. The $\beta$-1,6-glucan and mannoprotein are attached through a remnant of the mannoprotein GPI anchor. Reducing ends of $\beta-1,6-$ glucan may also be attached to the non-reducing end of $\beta-1,3$-glucan. The proportion of cell wall polysaccharide involved in this type of structure is not clear. The following cell wall building blocks is proposed mannoprotein - GPI remnant- $\beta$-1,6-glucan- $\beta$-1,3glucan — chitin (Kollar et al. 1995; Klis et al. 1997).

The percent composition of the cell wall building blocks in S. cerevisiae and filamentous fungi vary according to the growth form considered at a particular point of time (Calderone et al. 1991). Higher amounts of chitin present in the pseudo-hyphal cells of $C$. albicans suggest a similarity in cell wall structure to many filamentous organisms (Chattawa et al. 1968). Chitin is the first polymer to appear in regenerating protoplasts of C. albicans followed by ß-glucan (Murgui et al. 1986).

Synthesis of cell wall components like chitin and $\beta$-1,3-glucan take place at the plasma membrane. Mannoprotein is synthesized in the cytoplasm and transported through the classical secretory pathway, while $\beta$-1,6-glucan synthesis may occur partially in the endoplasmic reticulum or Golgi complex (Kollar et al. 1995). It is suggested that protein and mannoprotein species may play a key role in configuring the final cell wall structure characteristic of S. cerevisiae, C. albicans or other fungal organisms (Ruiz-Herrera 1992).

\subsection{Structural organization of cell wall}

In order to shed more light on the structure of fungal cell wall, electron microscopic analysis is widely used in combination with negative staining techniques (Scherrer et al. 1974; Lipke et al. 1998). Electron microscopic analysis revealed a two layered cell wall structure in most of the fungal walls, an outer layer, which is normally amorphous or granular, and electron dense and an inner layer normally thicker, multi-lamellated and 
electron transparent. The composition of both the layers is distinct from each other (Klis et al. 2002). Investigations in S. cerevisiae confirmed this general model of cell wall structure, where an electron-transparent internal layer of about 70-100 nm thick mass depending on growth conditions and genetic background, and an electron-dense outer layer were found (Cappellaro et al. 1994; Osumi 1998).

In addition to the above, studies performed by researchers on C. albicans have reported the presence of three to eight different layers (Poulain et al. 1978; Hazen et al. 1992). The outer cell wall layer appears as a dense network with a fibrillar appearance, whereas the inner wall layer appears continuous with the plasmalemma with extensive membrane invaginations involved in anchoring of the cell wall to the membrane (Kusamichi et al. 1990). The microfibrillar polysaccharides glucan and chitin, the components that supply rigidity to the overall wall structure, appear to be more concentrated in the inner cell wall layer, adjacent to the plasma membrane. In contrast, proteins and mannoproteins appear to be dominant in the outermost cell wall layer. Some of the proteins may be covalently associated with glucans. Evidence from several cytochemical and cytological studies indicate that the cell wall layering may be due to the distribution of mannoproteins at various levels within the wall structure. In any case, it seems clear that layering may be the result of quantitative differences in the proportions of the individual wall components (ß-glucans, chitin, mannoproteins) in each layer rather than of qualitative differences (Odds et al. 1985).

The outer cell wall layer that is composed mainly of mannoproteins appears as a dense network of radially projecting fibrils, designated fimbriae (Yu et al. 1994). These fibrils extend for 100 to $300 \mathrm{~nm}$ (Hazen et al. 1992; Kusamichi et al. 1990) and are approximately $5 \mathrm{~nm}$ in diameter. C. albicans fimbriae consist of many subunits assembled through noncovalent hydrophobic interactions ( $\mathrm{Yu}$ et al. 1994). The major structural subunit of fimbriae is a glycoprotein with an apparent molecular mass of 66 $\mathrm{kDa}$, while the unglycosylated protein has an approximate molecular mass of $8.64 \mathrm{kDa}$ (Yu et al. 1994).

The cell wall structures in fungi may change depending on the developmental stage at which they appear. The inner layer consisting of $\beta$ 1,3-glucan and chitin, contributes 
about $50-60 \%$ of the cell wall dry weight. In addition, these components are responsible for the mechanical strength of cell wall (Klis et al. 1997). Heavily glycosylated mannoproteins originating from the cell surface form the outer layer of cell wall (Baba et al. 1987; Cappellaro et al. 1994). These glycosylated mannoproteins are involved in cellcell recognition events (Lipke et al. 1992; Cappellaro et al. 1994; Teunissen et al. 1995; Reynolds et al. 2001) and forms a shield for the accessibility of the inner part of the wall and the plasma membrane to foreign enzymes such as cell wall-degrading enzymes in plant tissue (Zlotnik et al. 1984; De Nobel et al. 2000). A negative charge is created at the cell surface at physiological $\mathrm{pH}$ values because of phosphodiester bridges present in carbohydrate side chains of the cell surface proteins (Jigami et al. 1999). These side chains are responsible for the hydrophilic properties of the wall, and may be involved in water retention and drought protection. The outer mannan-protein layer makes about one third of the cell wall dry weight. The cell wall proteins are covalently linked to the $\beta 1,3-$ glucan-chitin network either indirectly through a $\beta 1,6$-glucan moiety or directly. In addition, some proteins are disulfide-bonded to other cell wall proteins (Orlean et al. 1986; Moukadiri et al. 1999).

An appropriate architecture to the cell wall is given by interaction of different cell wall components. Apart from hydrogen and hydrophobic bonds, there is also experimental evidence for the presence of covalent linkages between different components (RuizHerrera 1992). Presence of glycosidic linkages between glucan and chitin in the nascent wall of C. albicans has been reported by Surarit and co-workers (Surarit et al. 1988). Establishment of covalent association of mannoproteins with $\beta$-glucans have been reported (Kapteyn et al. 1994; Kapteyn et al. 1995).

\subsection{Properties and function of the cell wall}

The discussion so far indicates that the cell wall is a robust yet highly elastic structure which is rather critical to the survival of a fungal cell in its diverse environment. The elastic nature of the cell wall is demonstrated by the fact that when the yeast cells are kept in hypertonic solution, they rapidly shrink and, depending on the osmotic stress, they may lose more than $60 \%$ of their initial volume. However, when these cells are 
transferred back to the original medium, they immediately expand to their initial volume (Morris et al. 1986; De Maranon et al. 1996). Isolated walls are permeable only to molecules of lower molecular weight for e.g. molecules of molecular mass up to $760 \mathrm{Da}$ (Scherrer et al. 1974). In contrast, the cell walls of living cells are permeable to much larger molecules especially under hypotonic conditions and also depending on growth conditions (Gooday 1995).

One of the main functions of fungal cell walls is to provide mechanical stability and rigidity to the cells, to protect against microbial attack, and regulate water transport, in which the chitin components play a key role (Gooday 1995).

In addition to the response to osmotic stress, the fungal cell wall was also shown to mediate resistance towards osmotin, a plant defense protein, in the model fungus $S$. cerevisie (Ibeas et al. 2001). In Aspergillus niger, expression of 1,3- $\alpha$-D-glucan synthases was observed in the presence of cell wall stress-inducing compounds such as SDS (sodium dodecyl sulphate) and the antimycotic compound caspofungin (Damveld et al. 2005). Similarly in the basidiomycete Lentinula edodes, a strong stimulation of B-1-3glucan synthase was recorded in the cultures grown on olive mill wastewaters or in the presence of various phenols (Reverberi et al. 2004). These findings well demonstrate the role of cell wall or its components in stress response in fungal cultures.

Moreover, melanins present in the fungal cell wall represent virulence factors for several pathogenic fungi (Jacobson 2000). Melanization stabilizes the external cell wall against hydrolysis and it is thought to determine semi-permeability in the appressorium of certain plant pathogens. Additional to this, an independent hypothesis holds that in the basidiomycetous yeast Cryptococcus neoformans an important function of the melanizing enzyme (apart from melanization) is the oxidation of $\mathrm{Fe}$ (II) to $\mathrm{Fe}$ (III), thereby preventing the generation of the harmful hydroxyl radical from $\mathrm{H}_{2} \mathrm{O}_{2}$ (Jacobson 2000). Cell wall components like chitin or melanins have been shown to be responsible for the heavy metal binding capacity of fungal organisms. However, the chemical nature of heavy metal binding in the fungal cells is still not fully clear (Galli et al. 1994). 
While working with Pisolithus tinctorius, a basidiomycete, Martin and co-wokers demonstrated the role of cell wall proteins during symbiotic interactions in ectomycorrhizal fungi (Martin et al. 1999). Cell wall glycoproteins were also reported to be involved in different developmental processes in fungal cultures such as mating, invasive growth, and cell-cell adhesion (Guo et al. 2000). Many other cell wall proteins from fungi are involved in several important cellular functions and are discussed in the next section.

\subsection{Proteins and enzymes in the cell wall of ascomycetes}

A large number of proteins and enzymes are associated with the cell wall of ascomycetes. These proteins are classified as Cell Wall associated Proteins (CWPs). These CWPs are highly glycosylated and form the outer layer of the cell wall. Many of the cell wall glycoproteins are considered to be catalytically active (Mrsa et al. 1999). Due to the presence of disulfide bridges and long and highly branched carbohydrate side chains linked to asparagine residues in the proteins, the outer mannoprotein layer is much less permeable to macromolecules (Zlotnik et al. 1984) than the internal fibrillar layer of the cell wall (Denobel et al. 1990a; Denobel et al. 1990b; Orlean 1997). Serine and threonine residues present in mannoproteins, which might also carry short oligomannosyl chains, are often clustered, resulting in relatively rigid rod like regions of the polypeptide backbone (Jentoft 1990; Chen et al. 1995). Extensive phosphodiester bridges, present in both $\mathrm{N}$ - and O-linked mannosyl side chains, contribute to the negative charge on the surface of the cell wall in yeasts (Orlean 1997; Jigami et al. 1999).

The proteins associated with the cell wall are thought to be responsible for several vital functions of the cell such as bringing about adhesion of yeast cells during sexual agglutination and flocculation, remodelling of $\beta$-glucan in the conjugation tube etc. (Erdman et al. 1998; Rodriguez-Pena et al. 2000). The CWPs are covalently coupled to the cell wall polysaccharides and can be categorised into two main classes (a) GPIdependent cell wall proteins (GPI-CWPs) and (b) Pir proteins (Pir-CWPs) (Fig. 1). 


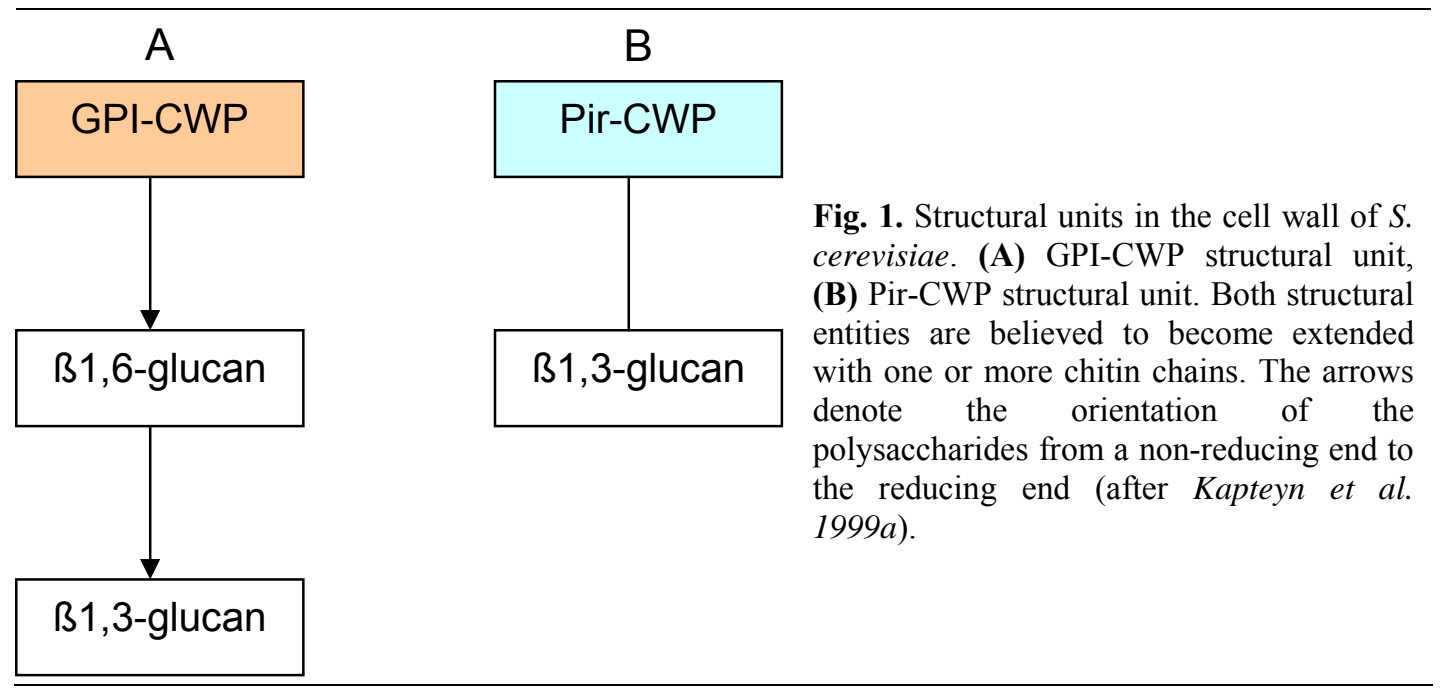

\subsubsection{GPI-dependent cell wall proteins (GPI-CWPs)}

About 60-70 GPI proteins have been identified in the genome of S. cerevisiae (Caro et al. 1997). About 40 of them are destined for the plasma membrane whereas the others become covalently linked to $\beta 1$,6-glucan (Lu et al. 1995; Kapteyn et al. 1996; Hamada et al. 1998; 1999; Fujii et al. 1999; Kollar et al. 1997).

The GPI-CWPs are generally indirectly linked to $\beta 1,3$-glucan through a connecting $\beta 1,6-$ glucan moiety. They often contain repeats and serine- and threonine-rich regions. The most extensively studied GPI-CWP is Sag1, which is involved in sexual agglutination (Schreuder et al. 1993; Cappellaro et al. 1994; Chen et al. 1995; Lu et al. 1995). Mature proteins only have a remnant of the original GPI anchor, that links them to $\beta$ 1,6-glucan (Kollar et al. 1997; Fujii et al. 1999). Interestingly, $\beta 1$,6-glucan extracted from cell walls by hot acetic acid is found to contain a minor amount of galactose (Manners et al. 1973).

\subsubsection{Pir proteins (Pir-CWPs)}

Pir proteins apparently link to $\beta 1,3$-glucan, through an alkali-sensitive linkage. In $S$. cerevisiae, a family of four such proteins has been found (Tohe et al. 1993; Kapteyn et al. 1999b; Mrsa et al. 1999). These proteins contain a highly conserved carboxy-terminal region with four cysteine residues in a conserved spacing pattern. Several Pir proteins like Pir1, Pir2/ Hsp150, Pir3, and Pir4/Cis3 have been localized to the cell wall by 
immunological methods in S. cerevisiae and C. albicans ( Yun et al. 1997; Moukadiri et al. 1999; Kapteyn et al. 2000).

Many other proteins, such as Pau1 and its homologues and Sps100, are thought to contribute to maturation of the spore wall (Law et al. 1988). Ygp1, which is induced by nutrient limitation, is predicted to have an N-terminal signal peptide, but not an additional signal for a GPI anchor (Destruelle et al. 1994). In addition, several cell wall proteins from S. cerevisiae such as Bar1, a protease (Moukadiri et al. 1999), Aga2 the active subunit of the sexual agglutinin complex in MATa cells (Watzele et al. 1988; Cappellaro et al. 1994), Pir4/Cis3 (Moukadiri et al. 1999), and some known or potential cell wall glycanases such asSun4/Scw3 (Cappellaro et al. 1998), can be released from intact cells using a reducing agent. This suggests that they might be linked by a disulfide bridge to other cell wall proteins. Reducing agents are also expected to release soluble, intermediate forms of GPI-CWPs ( $\mathrm{Lu}$ et al. 1994). Finally, SDS extraction of isolated walls releases many proteins. With a few exceptions, like the transglucosylase Bgl2 (Goldman et al. 1995) and the chitinase Cts1 (Kuranda et al. 1991; Colman-Lerner et al. 2001), they are not authentic cell wall proteins and their presence is explained due to contamination with membrane fragments (Klis 1994; Cappellaro et al. 1998; Klis et al. 2001).

Members of the Hsp (heat-shock protein) family (LopezRibot et al. 1996) and abundant glycolytic enzymes such as Tdh1, Tdh2, and Tdh3 (Delgado et al. 2001) are often found at the cell surface. They can be extracted from intact cells with a reducing agent such as mercaptoethanol under slightly alkaline conditions, suggesting that they are either trapped inside the wall or are ionically bound to cell surface proteins. It is not clear whether these proteins originate from lysed cells or whether they are exported by a nonconventional secretory mechanism (Pardo et al. 1999). Heat-shock proteins and glycolytic enzymes have also been found in the medium of regenerating spheroplasts, which raises the same question (Pardo et al. 1999). The cell wall proteins are postulated to have several vital functions in the cell. For example, various GPI-CWPs are involved in adhesion events like sexual agglutination and flocculation of yeast cells. Others such as Crh1, Crh2, and Crr1 appear to have an enzymatic function (Rodriguez-Pena et al. 
2000) and are required for the normal width of the conjugation tube (Erdman et al. 1998), suggesting that they may be involved in remodelling of $\beta$-glucan in the conjugation tube.

\subsubsection{Enzymes in the cell wall}

\subsubsection{Enzymes associated with the cell wall}

There are several enzymes associated to the cell wall, which are often described as WallAssociated Enzymes (WAEs) (Rast et al. 2003). These exoenzymes are assumed, for example, to be involved in the transformation of nutrients present in the medium. Numerous cell wall-associated proteins reveal enzymatic activities. Identified cell wall associated fungal exoenzymes fall into the following biochemical subclasses: oxidoreductases, O-glycosyltransferases, hexosyltransferases, aminoacyltransferases, phosphoric monoester hydrolases (Rast et al. 2003).

Of these, hexosyltransferases and O-glycosyltransferases were most often described in an extraprotoplastic location of the cell. The evidences presented for cell wall-association of particular enzymes generally were indirect, i.e., inferred from simple histochemical tests or immunocytochemical analyses or from genome analysis (Nicole et al. 1992; Rast et al. 2003). As most of the mannan CWPs are considered to be catalytically active (Mrsa et al. 1999), many more WAEs remain to be detected. Some WAEs reach the extraprotoplastic compartment in form of vesicles, called periplasmic bodies (Notario 1982; Weber et al. 1997). Glucanosyltransferases (Mouyna et al. 2000) are possibly directly released from their GPI-anchored state in the plasma membrane by hydrolytic/transglycosylating reactions (Kapteyn et al. 1999a; Mrsa et al. 1999; Klis et al. 2002). Most studies concerning fungal cell wall enzymes were performed on ascomycetous yeasts and filamentous ascomycetes and a few on zygomycetes. Some specific cell wall-associated enzymes detected in these fungi are:

i. B(1-3)-glucanosyltransferase in Candida albicans (Hartland et al. 1991)

ii. acid phosphatase in C. albicans, Aspergillus fumigatus and Botrytis cinerea (Molloy et al. 1995; Weber et al. 1997; Bahmed et al. 2002)

iii. phospho- and lysophospholipases in C. albicans (Chaffin et al. 1998)

iv. chitinase in Saccharomyces cerevisiae, C. albicans and Kluyveromyces sp. (Bahmed et al. 2002; Iranzo et al. 2002) 
v. B-glucosidase in C. albicans, Acremonium persicinum and Aspergillus kawachii (Ram et al. 1984; Iwashita et al. 1999; Pitson et al. 1999)

vi. trehalase in C. albicans and Neurospora crassa and in the zygomycete Mucor rouxii (Hecker et al. 1973; Ram et al. 1984; Molloy et al. 1995; Lucio et al. 2000)

vii. $\quad B(1-3)$-glucanase in C. albicans and A. persicinum (Ram et al. 1984; Pitson et al. 1999)

viii. $\quad B(1-6)$-glucanase in A. persicinum (Pitson et al. 1999)

ix. N-acetylhexosaminidase in C. albicans and M. rouxii (Rast et al. 1991; Molloy et al. 1995)

\subsubsection{The role of cell wall associated enzymes in filamentous fungi}

Some fungal WAEs (Wall-Associated Enzymes) have been identified from chemical and supramolecular structure of the wall of S. cerevisiae (van der Vaart et al. 1996; Kapteyn et al. 1999a; Klis et al. 2002) and ultrastructural dissection data from the walls of two filamentous fungi S. commune (Sietsma et al. 1977) and A. bisporus (Michalenko et al. 1976). These enzymes catalyze some of the basic reactions that are required to:

i. produce and mould major building blocks of the cell wall (Klis et al. 2002)

ii. combine these building blocks into a dynamically remodelled giant heteropolysaccharide - protein -lipid complex (Rast et al. 2003)

iii. finally transform the latter into an intrinsically non-hydrolysable material through oxidative coupling with phenolic residues (Rast et al. 2003)

\subsubsection{Attachment of WAEs to the cell wall}

The cell wall bound enzymes are more stable in a naturally immobilized form. Generally, WAEs are more stable when associated with WAPs (Ruiz-Herrera et al. 2002). Therefore studying WAEs can be instrumental in identifying WAPs (Wall associated proteins) since one would possibly find a number WAPs associated with the WAE under study (Montijn et al. 1999; Mrsa et al. 1999). The work of Iwashita et al. (1999) with Bglucosidase represents a good example for extraction and the study of a cell wall associated enzyme. The binding of WAPs to other components of the extra-cellular matrix (ECM) can be brought about by: (Iwashita et al. 1999)

i. hydrogen and (un-specific) weak ionic bonding, 
ii. $\quad$ van der Waals forces and hydro-phobic interactions

iii. strong electrostatic forces

iv. covalent linkage

Except the covalent linkage, the other forces are quite weak. Covalent binding of WAEs in the interface region between the plasma membrane/periplasmic reaction medium and the more densely packed part of the wall compartment might be a reason why such WAEs are apparently intrinsically more stable than their respective protoplastic forms (Dickerson et al. 1979; Horsch et al. 1996; Iwashita et al. 1999; Notario et al. 1979).

\subsection{Proteins and enzymes in the cell wall of basidiomycetes}

There are few well characterized structural cell wall proteins in basidiomycetes, for example, hydrophobins (Wösten 2001; Walser et al. 2003) and galectins (Walser et al. $2003 ; 2004 ; 2005)$. However, in comparison to ascomycetes much less is known about the enzymes present in cell walls of basidiomycetes. Many cell wall associated enzymes are responsible for basic reactions in cell wall synthesis (Sietsma et al. 2005; Latgé et al. 2006) while others contribute to breakdown of growth substrates. Using co-precipitation of gold particles with a phenolic laccase substrate, it has been shown that oxidative enzymes such as laccase can be confined to the outer region of the hypha in Pycnoporus cinnabarinus, a wood rotting basidiomycete. Laccase was found to be present in a higher concentration at the apical tip of the hypha as compared to the exterior subapical region where it had low concentration (Jones et al. 1999). A large number of fungal lignolytic enzymes have been studied using immuno-gold labelling both in culture and in degraded wood samples. For example, lignin peroxidase and manganese peroxidase $(\mathrm{MnP})$ were detected in degraded wood and on the surface of the fungal hypha (Ruel et al. 1991; Srebotnik et al. 1998). Daniel (1994) report that several redox- and hydrolytic enzymes are present in Lentinula edodes, Phellinus pini, Phanerochaete chrysosporium, Phlebia radiata, Rigidoporus lignosus, Trametes versicolor and Volvariella volvacea that have been localized to the cell wall by immuno-gold labelling. It has been shown that the 
secreted MnP in Ceriporiopsis subvermispora interacts directly with polyglucan of the cell wall and gets entrapped inside the hyphal polysaccharide sheath. It is therefore not released free into the surroundings and its diffusion into the wood substrate across the hyphal cell wall is limited to the space where the polysaccharides are present (Ruel et al. 2003). Further, Ruel and co workers (2003) found that in C. subvermispora, laccases were trapped inside the exopolysaccharides while in $P$. radiata they were present enmeshed in the cell walls. This was in corroboration with the report of Nicole and co workers who found similar association of laccases in the white rot fungus R. lignosus during wood degradation (Nicole et al. 1992). Additionally, immuno-gold labelling has been very successfully used for localization of a number of oxidative and hydrolytic enzymes, such as aryl alcohol oxidase, pyranose oxidase and cellulase, glucanase etc., to the cell wall and extracellular sheath and for monitoring their mobility inside the substrate (Cai et al. 1999). However, there are limitations to the usage of antisera raised using purified enzymes, i.e. it is not possible to detect any unknown enzymes and the antisera might not show reactivity towards modified forms of enzymes.

Few attempts were made to release cell wall associated laccases. For example, Zhu and co- workers reported that they could not release much of the cell wall-associated laccase in C. neoformans, even after sequential treatments with salt, urea and SDS. However, glucanase treatment could successfully release the laccase from the cell wall (Zhu et al. 2001).

Cell wall samples from A. bisporus sporocarps, showed phenoloxidase (tyrosinase) activity in several extracted fractions as well as in the leftover pellet. This could point towards the existence of several isoenzymes (Sassoon et al. 2001).

The recent release of $P$. chrysosporium genome has opened a gateway for proteomic studies on this species (Martinez et al. 2004). Several studies are being carried out, using 2D-electrophoresis and LC-MS, to identify extracellular proteins in this white-rot fungus. These studies have so far resulted in identification of 16 hydrolytic and oxidative enzymes from more than 45 gel-spots of proteins secreted into culture (Abbas et al. 2005). 


\subsection{Lignin degradation and enzymes}

Cellulose, hemicellulose and lignin are the main components to form plant biomass and are the major end product of photosynthesis. Out of this lignin is the second most abundant natural polymer on the earth, which constitutes up to $15-30 \%$ cell walls of gymnosperm (softwood) and angiosperm (hardwood) (Gold et al. 1993). Lignin is
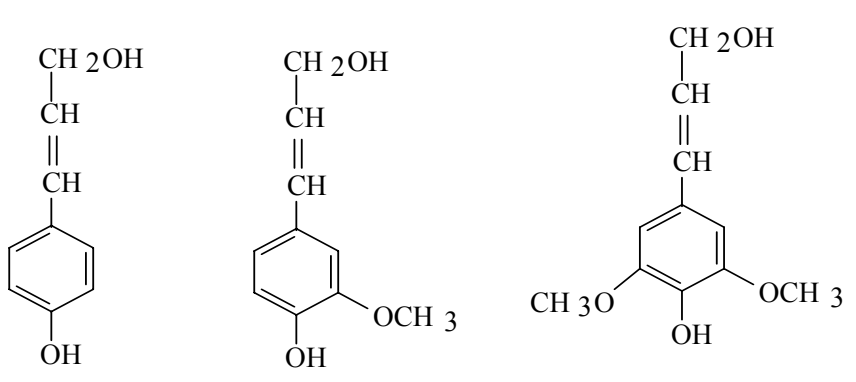

formed by oxidative coupling of phenylpropanoid precursors (Fig.

2) from left p-coumaryl alcohol, p-coniferyl alcohol and sinapyl

Fig. 2. The three precursors of lignin differing in the number of methoxyl groups on the aromatic ring from left to right: $p$-coumaryl alcohol, $p$-coniferyl alcohol and sinapyl alcohol (adopted from Erikson et al. 1990)

Lignin is a phenylpropanoid structural polymer of vascular plants, which provides them rigidity and binds the plant cell wall fibers together. The highly polymeric aromatic structure of lignin makes it difficult to be degraded and thereby makes wood resistant to be attacked by microorganisms. Lignin also decrease water permeation across the plant cell wall (Eriksson et al. 1990). White rot and brown rot basidiomyceteous fungi are the most important degraders of wood in nature (Tuor et al. 1995). The ability to degrade lignocellulose efficiently is thought to be associated with a mycelial growth habit, which allows the fungus to transport scarce nutrients (Eriksson et al. 1990). Their strategy to decompose the lignin in wood is to get access to the cellulose and hemicellulose that are embedded in the lignin matrix within the plant cell wall. Lignin is covalently associated with hemicellulose in the cell wall via numerous types of linkages such as ether bonds, ester bonds and lignin-glycosidic bonds (Tuor et al. 1995). The common products of lignin degradation are low molecular weight organic compounds such as vanillic acid, isovanillic acid, averatric acid and dehydrovanillic acid. The lignin degradation process is performed with the help of enzymes, and for some fungi mainly triggered in conditions of nitrogen starvation. The enzymes mainly involved in this process are oxidases and peroxidases: mainly lignin peroxidase (ligninases), Mn-dependent peroxidases, Mn-inde- 
pendent peroxidases and laccases (Leonowicz et al. 1999). These enzymes are extracellular in nature and can oxidize phenolic and non-phenolic groups of lignin, generating for example phenolic radicals and quinones that support actions of other enzymes, thereby carrying out a simultaneous attack on lignin as well as cellulose. Thus, the lignocellulosic compounds are converted to partially degraded polymers such as humic and fulvic acid and to low molecular weight organics as well as into $\mathrm{CO}_{2}$ (Leonowicz et al. 1999). Kirk and co-workers have termed the process "enzymatic combustion" since lignases activate lignin to overcome the threshold energy barrier and begin a thermodynamically favoured oxidative fragmentation of lignin without further control of the reaction pathway by these enzymes (Kirk et al. 1987). Biodegradation of lignin is a disorderly process, which proceeds by simultaneous removal of side chains from the outside of the lignin molecule and increased solubility of the polymer core at the same time, thereby producing fragments of varying size. Several mechanisms of delignification have been characterized in white rot fungi all of which show a fundamental similarity that is their dependence on the formation of lignin free radicals. The chemically unstable and therefore highly reactive free radicals spark off a chain reaction by undergoing subsequent spontaneous degradative reactions that lead to lignin breakdown (Eriksson et al. 1990).

\subsubsection{Degradation of lignocelluloses by white rot fungi}

A lignocellulose complex is degraded by three groups of cellulolytic enzymes, namely endo-1,4-ß-glucanases (EC 3.2.2.4), two types of exo-1,4-glucanases, and cellobiohydrolases and lignin-modifying enzymes like phenol oxidases, peroxidases and oxidases for degradation of lignin (Eriksson et al. 1990). Enzymes involved in lignocelluloses degradation are listed in Table 2.

\subsubsection{Lignin degrading enzymes of white rot fungi}

\subsubsection{Laccases}

Laccase (benzenediol: oxygen oxidoreductase; EC 1.10.3.2) has a rather wide distribution, being found in higher plants, many fungi, certain bacteria and insects. It is a member of the copper-containing oxidase family. It brings about the catalytic oxidation of a 
number of phenolic compounds and aromatic amines by reducing molecular oxygen to water. The physiological role of laccases has not been elucidated clearly, although they have been linked with the lignin substrates and implicated in lignin degradation (Bourbonnais et al. 1990; Bourbonnais et al. 1997).

Table 2. Enzymes involved in the degradation process of lignocelluloses

\begin{tabular}{|c|c|}
\hline Name of enzyme & Reaction \\
\hline Endo-1,4- $\beta$-glucanase (3.2.1.4) & Endohydrolysis of 1,4- $\beta$-D-glucosidic linkages of cellulose \\
\hline Exo-1,4- $\beta$-glucanase (3.2.1.91) & $\begin{array}{l}\text { Hydrolysis of } 1,4-\beta \text {-D-glucosidic linkages releasing } \\
\text { cellobiose from cellulose }\end{array}$ \\
\hline$\beta$-Glucosidase (3.2.1.21) & $\begin{array}{l}\text { Hydrolysis of terminal non-reducing } \beta \text {-D- glucose residues } \\
\text { with release of } \beta \text {-D-glucose }\end{array}$ \\
\hline Endo-1,4- $\beta$-xylanase (3.2.1.8) & $\begin{array}{l}\text { Endohydrolysis of } 1,4-\beta \text {-D-xylosodic linkages of } \\
\text { hemicellulose with xylans }\end{array}$ \\
\hline$\beta$-xylosidase (3.2.1.37) & $\begin{array}{l}\text { Hydrolysis of 1,4- } \beta \text {-D-xylans to remove successive D-xylose } \\
\text { residues }\end{array}$ \\
\hline Ligninase (1.11.1.14) & $\begin{array}{l}\text { Oxidation in alkyl side chains, C-C cleavage in side chain of } \\
\text { lignin, cleavage of aromatic ring, oxidation of benzyl alcohol } \\
\text { to aldhehydes }\end{array}$ \\
\hline$\alpha$-L-Arabinofuranosidase (3.2.1.55) & $\begin{array}{l}\text { Hydrolysis of } \quad \text { terminal } \\
\text { arabinofuranosidase residues in } \alpha \text {-L-arabinosidase }\end{array}$ \\
\hline Acetylesterase (3.1.1.6) & An acetic ester $+\mathrm{H}_{2} \mathrm{O}=$ an alcohol + acetate \\
\hline$\alpha$-Glucuronidase (3.2.1.139) & $\alpha$-D-glucuronosidase $+\mathrm{H}_{2} \mathrm{O}=$ an alcohol $+\mathrm{D}$-glucuronate \\
\hline$\beta$-Mannosidase (3.2.1.25) & $\begin{array}{l}\text { Hydrolysis of terminal } \beta \text {-D-mannose residues in } \beta \text {-D- } \\
\text { mannosides }\end{array}$ \\
\hline$\alpha$-Galactosidase (3.2.1.22) & $\begin{array}{l}\text { Hydrolysis of terminal } \alpha \text {-D-galactose residues in } \alpha \text {-D- } \\
\text { galactosides }\end{array}$ \\
\hline Mn-dependent peroxide (1.11.1.13) & Dependent on $\mathrm{H}_{2} \mathrm{O}_{2}$ and $\mathrm{Mn}^{2+}$ \\
\hline Laccase (1.10.3.2) & 4-Bezendiol $+\mathrm{O}_{2}=4$-benzosemiquinione $+2 \mathrm{H}_{2} \mathrm{O}$ \\
\hline Horseradish peroxide (1.11.1.7) & Donor $+\mathrm{H}_{2} \mathrm{O}_{2}=$ oxidized donor $+2 \mathrm{H}_{2} \mathrm{O}$ \\
\hline $\begin{array}{l}\text { Superoxide dismutase }(1.15 .1 .1) \\
\text { Glyoxalate oxidase }(1.2 .3 .5)\end{array}$ & $\begin{array}{l}\mathrm{O}_{2}{ }^{\cdots-}+\mathrm{O}_{2} \cdots^{\cdots-}+2 \mathrm{H}^{+}=\mathrm{O}_{2}+\mathrm{H}_{2} \mathrm{O}_{2} \\
\text { Glyoxylate }+\mathrm{H}_{2} \mathrm{O}+\mathrm{O}_{2}=\text { oxalate }+\mathrm{H}_{2} \mathrm{O}_{2}\end{array}$ \\
\hline Glucose-1-oxidase (1.1.3.4) & $\beta$-D-Glucose $+\mathrm{O}_{2}=$ D-glucono-1,5-lactone $+\mathrm{H}_{2} \mathrm{O}_{2}$ \\
\hline Aryl alcohol oxidase (1.1.3.7) & $\begin{array}{l}\text { An aromatic primary alcohol }+\mathrm{O}_{2}=\text { aromatic aldehyde }+ \\
\mathrm{H}_{2} \mathrm{O}_{2}\end{array}$ \\
\hline Pyranose-2-oxidase (1.1.3.10) & D-Glucose $+\mathrm{O}_{2}=$ 2-dehydro-D-glucose $+\mathrm{H}_{2} \mathrm{O}_{2}$ \\
\hline $\begin{array}{l}\text { Cellobiose:quinine oxidoreductase } \\
(1.1 .5 .1)\end{array}$ & Cellobiose + quinine $=$ cellobiono- 1.5 -lactone + phenol \\
\hline Cellobiose dehydrogenase (1.1.99.18) & $\begin{array}{l}\text { Cellobiose }+ \text { quinine }=\text { cellobiono-1.5-lactone }+ \text { reduced } \\
\text { acceptor }\end{array}$ \\
\hline
\end{tabular}

Table adopted and modified from Leonowicz et al. (1999). 
Laccases are extracellular glycoproteins with molecular weight of 60-80 kDa having 15$20 \%$ carbohydrate content. They are made up of 520-550 amino acid residues with an Nterminal secreting peptide. There are four copper atoms in each laccase molecule, which are held by one cysteine and ten histidine residues. These residues and a small stretch of sequence around the four regions where the copper ligands cluster are conserved (Thurston 1994). The four $\mathrm{Cu}$ ions in a resting laccase are arranged at three different sites, displaying all types of spectral properties known for $\mathrm{Cu}$ (Bonomo et al. 1998).

Laccase acts on substrates having a redox potential less than $0.5 \mathrm{~V}$ (Munoz et al. 1997). The enyzme shows high affinity towards aromatic compounds having phenolic, methoxyl and methyl groups but no affinity towards a nitro group bearing benzene ring or towards non-phenolic lignin related compounds. However, it may form aN enzyme-mediator complex when there is a redox barrier between the substrate and the enzyme. This is demonstrated by the fact that fungal metabolites such as 3-hydroxyanthranilate (Eggert et al. 1996), and syringaldehyde (Dejong et al. 1994) which act as mediators have been isolated in association with laccase. In addition, in vitro oxidizable substrate ABTS [2,2'azino-bis(3-ethylenbenzathiazoline-6-sulfonic-acid)] has been shown to be a good redox mediator (Bourbonnais et al. 1997; Munoz et al. 1997). Laccase can catalyze reactions in combination with several redox mediators to oxidize nonphenolic lignin structures (Bourbonnais et al. 1997; Call et al. 1997). Degradation of lignin by fungi lacking lignin peroxidases could possibly occur through this indirect mode of action on non-phenolic groups of lignin. Since many white rot fungi synthesize several types of laccase, it can be assumed that they may vary in their ability to react with different substrates directly and their ability to react with mediators (Eriksson et al. 1990).

\subsubsection{Peroxidases}

The role of peroxidase in lignin degradation was brought into light from experiments where enzyme catalase was found to inhibit lignin degradation (Faison et al. 1983). Following this, two types of peroxidases involved in the lignin degradation, namely lignin peroxidase (LiP) and manganese- dependent peroxidase (MnP), were described (Tien et al. 1984). 
Lignin peroxidase (LiP) also called ligninase is a hemeprotein that is produced by many white-rot fungi (Kirk et al. 1987) and that is approximately 37,000 daltons in size. It bears structural and mechanical similarity to the more familiar plant peroxidases and utilizes hydrogen peroxide and organic peroxides to oxidize a variety of substrates (Tien et al. 1986). They differ from the other oxidoreductases in that they have very low $\mathrm{pH}$ optima and much higher redox potentials.

Lignin peroxidases can act on a wide range of substrates with their reactivity being largely determined by the redox potential of the substrate. They can catalyze the oxidation of substrates with a reduction potential greater than or equal to $7.55 \mathrm{eV}$ (Hammel et al. 1986). In their work, Haemmerli et al. (1986) showed that lignin peroxidases oxidize lignin monomers, dimers and trimers as well as polycyclic aromatic compounds such as benzopyrene. It can catalyse oxidation of both phenolic and nonphenolic aromatic compound as substrates; the phenolic compounds are oxidized to yield products similar to those produced by classical peroxidases, while the oxidation of the nonphenolic methoxybenzenes is unique to the lignin peroxidases (Kersten et al. 1985).

$\mathrm{H}_{2} \mathrm{O}_{2}$ is required for the catalytic reaction carried out by LiP. These reactions are neither substrate-specific nor stereo-specific. In a LiP-catalyzed reaction, the heme-containing enzyme is first oxidized by $\mathrm{H}_{2} \mathrm{O}_{2}$ to generate the two-electron oxidized intermediate, Compound I (Koduri et al. 1995). Compound I is then reduced by one electron donated by a substrate molecule (such as veratryl alcohol or $\mathrm{H}_{2} \mathrm{O}_{2}$ ) to give a 1-electron oxidized enzyme intermediate, Compound II, and a free radical product. The so formed radical intermediate can then act on lignin or other substances. The catalytic cycle is subsequently completed by the one-electron reduction of Compound II by a second substrate molecule (Renganathan et al. 1986). In the absence of a reducing substrate, Compound II can undergo a series of reactions with $\mathrm{H}_{2} \mathrm{O}_{2}$ to form Compound III, oxyperoxidase (Renganathan et al. 1986; Cai et al. 1992). Compound III decays either spontaneously or in the presence of $\mathrm{H}_{2} \mathrm{O}_{2}$ and a reducing substrate to give ferric LiP and $\mathrm{O}_{2}$. In addition, a number of studies have proposed an important role of veratryl alcohol (VA), a fungal secondary metabolite, in stimulating LiP-mediated oxidation of a large 
number of resistant substrates, such as small aromatic compounds, lignin and proteins. Some authors propose that VA acts as a redox mediator and facilitates the turnover of the enzyme and protects it from $\mathrm{H}_{2} \mathrm{O}_{2}$ inactivation (Dejong et al. 1994).

Therefore, LiP catalyzes veratryl alcohol to veratryl aldehyde, with the enzyme bound veratryl alcohol cation radical (VA) forming an unstable intermediate (Khindaria et al. 1995). This highly unstable intermediate is stabilized by the acidic microenvironment in the active site of the enzyme, which prevents deprotonation of the radical and its subsequent reaction with the oxygen. This radical can act as a redox mediator but not as a diffusible oxidant for LiP-catalyzed lignin degradation (Khindaria et al. 1996).

\subsubsection{Manganese dependent peroxidase}

Manganese dependent peroxidase (MnP) is heme-containing enzyme and oxidizes $\mathrm{Mn}$ (II) to $\mathrm{Mn}$ (III) that chelates with organic acids that form the principal substrates of the enzyme. This Mn III-organic acid complex can freely diffuse away from the active site of the enzyme (Mester et al. 1998) and can oxidize secondary substrates such as phenolic compounds, lignin model compounds (Wariishi et al. 1988; Wariishi et al. 1989; Tuor et al. 1992), high molecular weight chlorolignin (Lackner et al. 1991), chlorophenols (Grabski et al. 1998) etc. MnP can utilize both hydrogen peroxide and various organic hydroperoxides, such as syringic acid, ferulic acid, sinapic acid etc. (Eriksson et al. 1990).

$\mathrm{MnP}$ is a glycoprotein with varying degree of carbohydrate content in different isoenzymes (Pease et al. 1989). In P. chrysosporium MnP, the mature protein has a calculated molecular weight of 37,711 dalton and contains 358 amino acids which is preceded by a leader peptide of 24 amino acid residues (Pease et al. 1989). Based on their structural studies Sundaramoorthy et al. proposed a three dimensional structure of MnP containing a single binding site for Mn (II) on the surface of the protein. This binding site is acidic in character and is comprised of three carboxylate ligands, a heme propionate oxygen and two water molecules (Sundaramoorthy et al. 1994). However, Mauk et al. (1998) proposed a two Mn (II) binding sites in MnP. Youngs et al. (2000) showed that $\mathrm{MnP}$ contains two $\mathrm{Ca}$ ions that are thought to provide thermal stability to the enzyme. 


\subsubsection{Manganese independent peroxidase}

Ligninolytic cultures of several white rot fungi have been found to produce peroxidases different from $\mathrm{MnP}$ and $\mathrm{LiP}$ which are sometime referred to as $\mathrm{MiP}$ which was identified as distinct from MnP by its independence of $\mathrm{Mn}^{2+}$ ions (Waldner et al. 1988; Nerud et al. 1991). The role of these enzymes in lignin degradation is not well elucidated. Comparative studies done on the different kinds of peroxidases showed that the ligninolytic activity of MiP responded differently towards inhibitors than of LiP and $\mathrm{MnP}$ except of cysteine, to which the three activities were equally sensitive but differed in the mode of inhibition. MiP activity was detected in T. versicolor, P. chrysosporium and Coriolopsis polyzona (Waldner et al. 1988; Nerud et al. 1991).

\subsubsection{Generation of hydrogen peroxide}

It is thought that for the generation of oxygen radicals, laccase requires presence of $\mathrm{H}_{2} \mathrm{O}_{2}$ extracellularly. Different white-rot fungi have different mechanisms for generation of hydrogen peroxide. Aryl-alcohol oxidase (AAO) and glyoxal oxidase (GOX) are implicated to be the main enzymes involved in production of $\mathrm{H}_{2} \mathrm{O}_{2}$ extracellularly. Generation of $\mathrm{H}_{2} \mathrm{O}_{2}$ by AAO may involve a catalytic system. Benzyl alcohols are oxidized to benzaldehydes and to lesser extent benzaldehydes to benzoic acid by AAO under production of $\mathrm{H}_{2} \mathrm{O}_{2}$ during the reaction. Aryl-alcohol dehydrogenase (AAD) then reduces benzaldehyde and benzoic acid to regenerate the benzylalcohols (Guillen et al. 1992; Guillen et al. 1994). Initially, there is a two-electron reduction of the aldehyde by $\mathrm{AAD}$ and the subsequent electron transfer from veratryl alcohol to oxygen catalyzed by AAO. AAD requires high cellular NADPH as its reducing power (Muheim et al. 1991). Thus, the continuous production of $\mathrm{H}_{2} \mathrm{O}_{2}$ requires a large drain of the reducing equivalents. However, this is not a problem for the white-rot fungi since there is excessive carbon in nature which can readily be used as a source of reducing equivalents for lignin degradation.

The other enzyme capable of generating $\mathrm{H}_{2} \mathrm{O}_{2}$ is glyoxal oxidase, a copper metalloenzyme, produced by wood-rot fungi and forms an essential component of the extracellular lignin degradation pathways (Whittaker et al. 1999). It contains a free 
radical-coupled copper active site (Whittaker et al. 1996). It uses simple aldehyde, $\alpha-$ hydroxycarbonyl, or $\alpha$-dicarbonyl compounds as substrates to produce $\mathrm{H}_{2} \mathrm{O}_{2}$. The activity of glyoxal oxidase is expressed during secondary metabolism, when the ligninases are also expressed. Work of Hammel et al. (1994) demonstrated release of 0.80.9 equivalent of glycolaldehyde (a glyoxal oxidase substrate) in P. chrysosporium, after each $\mathrm{C} \alpha-\mathrm{C} \beta$ cleavage of the arylglycerol $\beta$-aryl ether lignin model 1-(3,4-dimethoxyphenyl)-2-phenoxypropane-1,3-diol (Hammel et al. 1994). Further, in the same work oxidation of glycolaldehyde by GOX (glyoxal oxidase) then yielded 0.9 and 2.8 molecules of oxalate and $\mathrm{H}_{2} \mathrm{O}_{2}$, respectively per reaction. The cleavage of arylglycerol $\alpha$ aryl ether structures by ligninolytic enzymes eventually recycles $\mathrm{H}_{2} \mathrm{O}_{2}$, useful for subsequent cleavage reactions (Hammel et al. 1994).

Methoxyl groups in lignin are attacked by alcohol oxidases to form methanol which is further oxidized to aldehydes thereby producing $\mathrm{H}_{2} \mathrm{O}_{2}$ (Eriksson et al. 1990). Other oxidases that have been postulated as likely possible donors of $\mathrm{H}_{2} \mathrm{O}_{2}$ are glucose 1oxidase (Kelley \& Reedy 1986 a,b) and fatty acyl-coenzyme A oxidase (Greene and Gould, 1984).

Cellobiose dehydrogenase $(\mathrm{CDH})$ is involved in lignin degradation and carries out one electron reductions of a range of substrates such as quinones, semiquinones, organic free radicals etc., by simultaneously oxidizing cellobiose to cellobionolactone (Archibald et al. 1997). CDH is known to be present in different fungi including the white rot $T$. versicolor, $P$. chrysosporium etc. and has been given various names like cellobiose oxidoreductase (CBO) and cellobiose:quinone oxidoreductase (CBQ). Although the biological function of $\mathrm{CDH}$ has not been fully understood, a mechanism that involves hydroxyl radical generation has been suggested. It is implicated that the radical can degrade and modify cellulose, hemicellulose and lignin (Archibald et al. 1997).

\subsection{Extraction of cell wall associated proteins}

Proteins that are found in the in-vitro growth medium are often called secreted or extracellular proteins. To reach the outer surface of the organisms, these proteins have to travel through the cell wall. Next to the growth medium, the cell wall is also regarded as 
an extra-cellular entity. Various enzymes like laccases, Mn peroxidases etc. have been already identified to be associated with the cell wall and with the growth medium (supernatant) of growing cultures (Ruel et al. 1991; Nicole et al. 1992; Srebotnik et al. 1998; Zhu et al. 2001).

Different techniques have been used to extract cell wall components of $S$. cerevisiae, $C$. albicans, Aspergillus and other ascomycetes. These include physical, chemical, and enzymatic methods or a combination of these. The choice of extracting reagents and techniques, the sequence of extraction methods, and the use of either intact cells or purified cell walls as the starting material may affect both qualitative and quantitative solubilization of cell wall components. In general, and especially due to the insolubility of both chitin and glucans, sequential alkali and acid treatments are required to effect their extraction (Klis et al. 1997). By a variety of techniques, proteinaceous components have been extracted or solubilized from the cell wall of S. cerevisiae, C. albicans, Aspergillus and other related fungi from both isolated cell walls and intact cells (Smail et al. 1984; Ponton et al. 1986; Sundstrom et al.1987; Marcilla et al. 1991; Sundstrom et al. 1985). These methods involve either the use of detergents (such as SDS or noctylglucoside), reducing agents [such as dithiothreitol (DTT) and ß-mercaptoethanol $(B \mathrm{ME})]$, or hydrolases (such as proteases, zymolyase or other ß-glucanases, and chitinases) alone or in combinations with each other. Although sulfhydryl compounds such as $B M E$ appear to be less efficient than hydrolases such as zymolyase in releasing cell wall-bound proteins and glycoproteins (Lopez-Ribot et al. 1991), these chemical agents were able to solubilize a complex array of proteinaceous components from the walls of intact C. albicans cells (Casanova et al. 1991). On the other hand, some Bglucanases used to solubilize cell wall moieties actually are enzymatic complexes that may contain other unidentified or uncontrolled hydrolytic activities, which may alter the native characteristics of the released molecules.

Other less frequently reported extraction procedures include chemical, enzymatic, and physical methods alone or in combination. B-elimination with $\mathrm{NaOH}$ has been used to release putative structural proteins (Fig. 3) (Mormeneo et al. 1994). Ethylenediamine has also been used in structural studies to extract proteins from the cell wall of C. albicans 
(Ruiz-Herrera et al. 1994). Salt $(\mathrm{NaCl})$ was used to extract the surface proteins in $C$. albicans (Brawner et al. 1984).

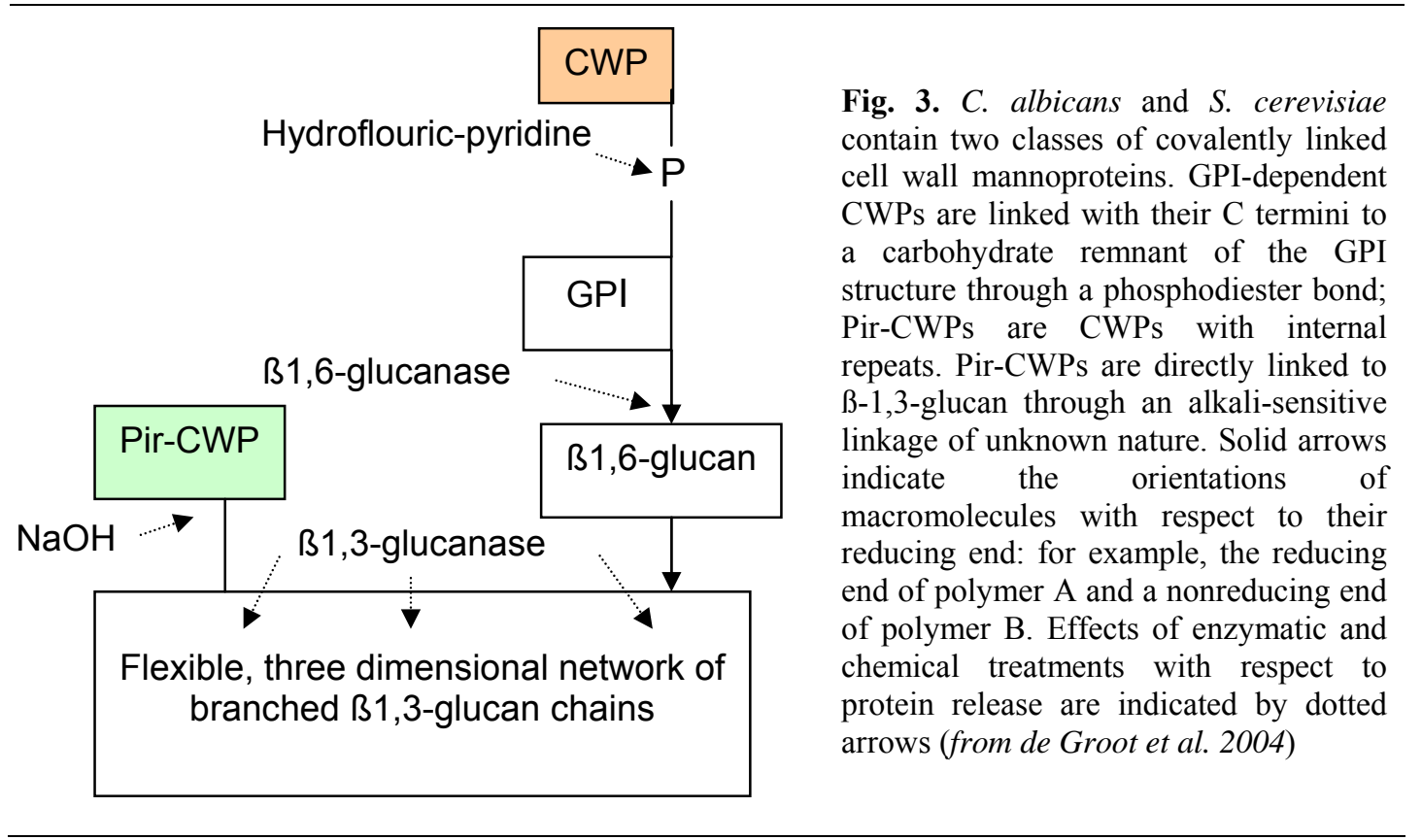

Homogenization has been used to shear fimbriae ( $\mathrm{Yu}$ et al. 1994), and $\alpha$-mannosidase treatment followed by sonication has been used to release wall antigens for C. albicans (Hernando et al. 1993). BME and other reducing reagents are believed to solubilize mainly components associated with the outermost layers of the cell wall (Calderone et al. 1991; LopezRibot et al. 1991). The reagents also increase cell wall porosity and facilitate subsequent action of cell wall degrading enzymes (Zlotnik et al. 1984). The hydrolysis of glucan by zymolyase or glucanases may release proteins enmeshed or covalently attached to the glucan, which are postulated to represent species contributing to cell wall structure (Casanova et al. 1989). Covalent attachment of mannoprotein to glucan, perhaps through phosphodiester linkages has been suggested (Kapteyn et al. 1994; 1995; Sanjuan et al. 1995; 1996).

However, it is a matter of concern if the cell wall proteins obtained from the abovementioned procedures are pure. It has been suggested that treatment of intact C. albicans 
cells with reducing agents (DTT or BME) may release also some intracellular macromolecular components (Calderone et al. 1991).

\subsection{Objective of the thesis}

During last decades numerous studies have been performed to elucidate the structure and the function of the cell wall of ascomycetes. The cell wall associated proteins are responsible for several essential functions e.g. cell wall synthesis, cell adhesion, pigment formation, pathogenicity etc. In contrast to the ascomycetes, very little is known about the cell wall structure and proteins of basidiomycetes. Participation of cell wall bound enzymes in wood degradation processes have been suggested in different studies. Previous studies showed that in wood rotting fungi, the fungal cell wall and the supernatant harbour oxidative and hydrolytic enzymes necessary for the degradation of lignocellulosic substrates. Additionally, there can be other unknown cell wall-associated and supernatant enzymes that contribute to the process of wood degradation. The aim of this thesis was to identify, characterize and compare enzymes, especially laccase, from the cell walls and culture supernatants of Trametes versicolor by using proteomic approaches with an emphasis on following objectives:

\section{Developing a method for isolation of high quality cell wall samples}

Different previously described mechanical methods were tested for disruption of hyphae of the basidiomycetous fungi T. versicolor.. The degree of cell wall breaking and purity of cell wall preparation were controlled by using scanning electron microscopy and cytosolic/mitochondrial enzyme markers and the best method was defined (Chapter 2).

\section{Comparison and development of methods for detection and identification of oxidative enzymes}

Fungal enzymes from T. versicolor and Coprinopsis cinerea were separated by 1D- and 2D-electrophoresis and the detection of oxidative enzymes were performed in gel by 
using substrates, coreactants and combination of substrate and coreactants. Identification of oxidative enzymes were done by using mass spectrometry (Chapter 3).

\section{Detection of cell wall laccase and comparison}

Cell wall associated laccase(s) from $T$. versicolor were detected in non-induced and induced culture conditions. Release of these laccase(s) were tried by chemical and enzymatic digestions of cell wall structures.

Cell wall associated laccase(s) were characterized and compared in enzymatic properties with purified supernatant laccase(s). Identification of cell wall and the supernatant laccase(s) was done by mass spectrometry (Chapter 4,5$)$.

\section{Identification of extra-cellular proteins from $T$. versicolor and establishment of proteomics tools to study extra-cellular proteins from higher basidiomycetes}

Proteomic tools such as sample preparation, iso-electric focusing of protein samples, 2Delectrophoresis conditions, in-gel digestion protocols, mass spectrometry parameters etc. to study extra-cellular proteome of basidiomycetes were established. Extra-cellular proteins (supernatant, hyphal sheath, non-covalently and covalently bound proteins) from T. versicolor were analyzed by $2 \mathrm{D}$-electrophoresis and identified by mass spectrometry (Chapter 6).

\subsection{References}

Abbas A., Koc H., Liu F., and Tien M. (2005). Fungal degradation of wood: initial proteomic analysis of extracellular proteins of Phanerochaete chrysosporium grown on oak substrate. Current Genetics 47:49-56.

Archibald F.S., Bourbonnais R., Jurasek L., Paice M.G., and Reid I.D. (1997). Kraft pulp bleaching and delignification by Trametes versicolor. Journal of Biotechnology 53:215-236.

Baba M., and Osumi M. (1987). Transmission and scanning electron microscopic examination of intracellular organelles in freeze substituted Kloeckera and Saccharomyces cerevisiae yeastcells. Journal of Electron Microscopy Technique 5:249-261.

Bahmed K., Bonaly R., Wathier M., Pucci B., and Coulon J. (2002). Change of cell wall chitin content in amphotericin B resistant Kluyveromyces strains. FEMS Microbiology Letters 216:99-103. 
Bonomo R.P., Boudet A.M., Cozzolino R., Rizzarelli E., Santoro A.M., Sterjiades R., and Zappala R. (1998). A comparative study of two isoforms of laccase secreted by the white rot fungus Rigidoporus lignosus, exhibiting significant structural and functional differences. Journal of Inorganic Biochemistry 71:205-211.

Bourbonnais R., and Paice M.G. (1990). Oxidation of nonphenolic substrates an expanded role for laccase in lignin biodegradation. FEBS Letters 267:99-102.

Bourbonnais R., Paice M.G., Freiermuth B., Bodie E., and Borneman S. (1997). Reactivities of various mediators and laccases with kraft pulp and lignin model compounds. Applied and Environmental Microbiology 63:4627-4632.

Brawner D.L., and Cutler J.E. (1984). Variability in expression of a cell surface determinant on Candida albicans as evidenced by an agglutinating monoclonal antibody. Infection and Immunity 43:966-972.

Cabib E., Bowers B., Sburlati A., and Silverman S.J. (1988). Fungal cell wall synthesis - the construction of a biological structure. Microbiological Sciences 5:370-375.

Cai D.Y., and Tien M. (1992). Kinetic studies on the formation and decomposition of compoundII and compound-III reactions of lignin peroxidase with $\mathrm{H}_{2} \mathrm{O}_{2}$. Journal of Biological Chemistry 267:11149-11155.

Cai Y.J., Chapman S.J., Buswell J.A., and Chang S.T. (1999). Production and distribution of endoglucanase, cellobiohydrolase, and $\beta$-glucosidase components of the cellulolytic system of Volvariella volvacea, the edible straw mushroom. Applied and Environmental Microbiology 65:553-559.

Calderone R.A., and Braun P.C. (1991). Adherence and receptor relationships of Candida albicans. Microbiological Reviews 55:1-20.

Call H.P., and Mucke I. (1997). History, overview and applications of mediated lignolytic systems, especially laccase-mediator-systems (Lignozym(R)-process). Journal of Biotechnology 53:163-202.

Cappellaro C., Baldermann C., Rachel R., and Tanner W. (1994). Mating type specific cell-cell recognition of Saccharomyces cerevisiae cell wall attachment and active sites of a-agglutinin and $\alpha$-agglutinin. EMBO Journal 13:4737-4744.

Cappellaro C., Mrsa V., and Tanner W. (1998). New potential cell wall glucanases of Saccharomyces cerevisiae and their involvement in mating. Journal of Bacteriology 180:5030-5037.

Caro L.H.P., Tettelin H., Vossen J.H., Ram A.F.J., Vandenende H., and Klis F.M. (1997). In silicio identification of glycosylphosphatidylinositol anchored plasma membrane and cell wall proteins of Saccharomyces cerevisiae. Yeast 13:1477-1489. 
Casanova M., Gil M.L., Cardenoso L., Martinez J.P., and Sentandreu R. (1989). Identification of wall specific antigens synthesized during germ tube formation by Candida albicans. Infection and Immunity 57:262-271.

Casanova M., and Chaffin W.L. (1991). Cell wall glycoproteins of Candida albicans as released by different methods. Journal of General Microbiology 137:1045-1051.

Chaffin W.L., Lopez-Ribot J.L., Casanova M., Gozalbo D., and Martinez J.P. (1998). Cell wall and secreted proteins of Candida albicans: Identification, function, and expression. Microbiology and Molecular Biology Reviews 62:130-180.

Chattawa F.W., Holmes M.R., and Barlow A.J.E. (1968). Cell wall composition of mycelial and blastospore forms of Candida albicans. Journal of General Microbiology 51:367-379.

Chen M.H., Shen Z.M., Bobin S., Kahn P.C., and Lipke P.N. (1995). Structure of Saccharomyces cerevisiae $\alpha$-agglutinin - Evidence for a yeast cell wall protein with multiple immunoglobulin like domains with atypical disulfides. Journal of Biological Chemistry 270:26168-26177.

Colman-Lerner A., Chin T.E., and Brent R. (2001). Yeast Cbk1 and Mob2 activate daughterspecific genetic programs to induce asymmetric cell fates. Cell 107:739-750.

Damveld R.A., vanKuyk P.A., Arentshorst M., Klis F.M., van den Hondel C.A.M.J., and Ram A.F.J. (2005). Expression of agsA, one of five 1,3- $\alpha$-D-glucan synthase encoding genes in Aspergillus niger, is induced in response to cell wall stress. Fungal Genetics and Biology 42:165-177.

Daniel G. (1994). Use of electron microscopy for aiding our understanding of wood biodegradation. FEMS Microbiology Reviews 13:199-233.

De Nobel H., Ruiz C., Martin H., Morris W., Brul S., Molina M., and Klis F.M. (2000). Cell wall perturbation in yeast results in dual phosphorylation of the Slt2/Mpk1 MAP kinase and in an Slt2-mediated increase in FKS2-lacZ expression, glucanase resistance and thermotolerance. Microbiology-Uk 146:2121-2132.

Dejong E., Field J.A., and Debont J.A.M. (1994). Aryl alcohols in the physiology of ligninolytic fungi. FEMS Microbiology Reviews 13:153-188.

Delgado M.L., O'Connor J.E., Azorin I., Renau-Piqueras J., Gil M.L., and Gozalbo D. (2001). The glyceraldehyde-3-phosphate dehydrogenase polypeptides encoded by the Saccharomyces cerevisiae TDH1, TDH2 and TDH3 genes are also cell wall proteins. Microbiology 147:411417.

De Maranon I.M., Marechal P.A., and Gervais P. (1996). Passive response of Saccharomyces cerevisiae to osmotic shifts: Cell volume variations depending on the physiological state. Biochemical and Biophysical Research Communications 227:519-523.

Denobel J.G., Klis F.M., Munnik T., Priem J., and Vandenende H. (1990a). An assay of relative cell wall porosity in Saccharomyces cerevisiae, Kluyveromyces lactis and Schizosaccharomyces pombe. Yeast 6:483-490. 
Denobel J.G., Klis F.M., Priem J., Munnik T., and Vandenende H. (1990b). The glucanase soluble mannoproteins limit cell wall porosity in Saccharomyces cerevisiae. Yeast 6:491-499.

Destruelle M., Holzer H., and Klionsky D.J. (1994). Identification and characterization of a novel yeast gene - The Ygp1 gene product is a highly glycosylated secreted protein that is synthesized in response to nutrient limitation. Molecular and Cellular Biology 14:2740-2754.

Dickerson A.G., and Baker R.C.F. (1979). Binding of enzymes to fungal $\beta$-glucans. Journal of General Microbiology 112:67-75.

Eggert C., Temp U., Dean J.F.D., and Eriksson K.E.L. (1996). A fungal metabolite mediates degradation of non-phenolic lignin structures and synthetic lignin by laccase. FEBS Letters 391:144-148.

Elorza M.V., Murgui A., Rico H., Miragall F., and Sentandreu R. (1987). Formation of a new cell wall by protoplasts of Candida albicans: Effect of papulacandin B, tunicamycin and nikkomycin. Journal of General Microbiology 133:2315-2325.

Erdman S., Lin L., Malczynski M., and Snyder M. (1998). Pheromone regulated genes required for yeast mating differentiation. Journal of Cell Biology 140:461-483.

Eriksson K.E.L., Blanchette R.A., and Ander P. (1990). Biodegradation of Lignin, In: Microbial and Enzymatic Degradation of Wood and Wood Components (Timell T.E. ed.), SpringerVerlag, New York, pp. 225-399

Faison B.D., and Kirk T.K. (1983). Relationship between lignin degradation and production of reduced oxygen species by Phanerochaete chrysosporium. Applied and Environmental Microbiology 46:1140-1145.

Fujii T., Shimoi H., and Iimura Y. (1999). Structure of the glucan-binding sugar chain of Tip1p, a cell wall protein of Saccharomyces cerevisiae. Biochimica et Biophysica Acta-General Subjects 1427:133-144.

Galli U., Schuepp H., and Brunold C. (1994). Heavy-metal binding by mycorrhizal fungi. Physiologia Plantarum 92:364-368.

Gold M.H., and Alic M. (1993). Molecular biology of the lignin degrading basidiomycete Phanerochaete chrysosporium. Microbiological Reviews 57:605-622.

Goldman R.C., Sullivan P.A., Zakula D., and Capobianco J.O. (1995). Kinetics of $\beta$-1,3-glucan interaction at the donor and acceptor sites of the fungal glucosyltransferase bncoded by the Bgl2 gene. European Journal of Biochemistry 227:372-378.

Gooday G.W. (1995). The growing fungus, In: Cell Wall $\mathbf{1}^{\text {st }}$ Edition (Gow N.A.R., Gadd G.M. eds.), Chapmann and Hall, London, pp. 43-62

Grabski A.C., Grimek H.J., and Burgess R.R. (1998). Immobilization of manganese peroxidase from Lentinula edodes and its biocalalytic generation of Mn-III-chelate as a chemical oxidant of chlorophenols. Biotechnology and Bioengineering 60:204-215. 
Greene R. V., and Gould J. M., (1984). Fatty acyl-coenzyme A oxidase activity and $\mathrm{H}_{2} \mathrm{O}_{2}$ production in Phanerochaete chrysosporium mycelium. Biochemical and Biophysical Research Communications 157:992-999.

Guillen F., Martinez A.T., and Martinez M.J. (1992). Substrate specificity and properties of the aryl alcohol oxidase from the ligninolytic fungus Pleurotus eryngii. European Journal of Biochemistry 209:603-611.

Guillen F., Martinez A.T., Martinez M.J., and Evans C.S. (1994). Hydrogen peroxide producing system of Pleurotus eryngii involving the extracellular enzyme aryl alcohol oxidase. Applied Microbiology and Biotechnology 41:465-470.

Guo B., Styles C.A., Feng Q.H., and Fink G.R. (2000). A Saccharomyces gene family involved in invasive growth, cell-cell adhesion, and mating. Proceedings of the National Academy of Sciences of the United States of America 97:12158-12163.

Haemmerli S.D., Leisola M.S.A., Sanglard D., and Fiechter A. (1986). Oxidation of benzo(A)pyrene by extracellular ligninases of Phanerochaete chrysosporium veratryl alcohol and stability of ligninase. Journal of Biological Chemistry 261:6900-6903.

Hamada K., Terashima H., Arisawa N., and Kitada K. (1998). Amino acid sequence requirement for efficient incorporation of glycosylphosphatidylinositol associated proteins into the cell wall of Saccharomyces cerevisiae. Journal of Biological Chemistry 273:26946-26953.

Hamada K., Terashima H., Arisawa M., Yabuki N., and Kitada K. (1999). Amino acid residues in the $\omega$-minus region participate in cellular localization of yeast glycosylphosphatidylinositolattached proteins. Journal of Bacteriology 181:3886-3889.

Hammel K.E., Kalyanaraman B., and Kirk T.K. (1986). Oxidation of polycyclic aromatic hydrocarbons and dibenzo[P]-dioxins by Phanerochaete-Chrysosporium ligninase. Journal of Biological Chemistry 261:6948-6952.

Hammel K.E., Mozuch M.D., Jensen K.A., and Kersten P.J. (1994). $\mathrm{H}_{2} \mathrm{O}_{2}$ recycling during oxidation of the arylglycerol beta aryl ether lignin structure by lignin peroxidase and glyoxal oxidase. Biochemistry 33:13349-13354.

Hartland R.P., Emerson G.W., and Sullivan P.A. (1991). A secreted $\beta$-glucan branching enzyme from Candida albicans. Proceedings of the Royal Society of London Series B-Biological Sciences 246:155-160.

Hazen K.C., and Hazen B.W. (1992). Hydrophobic surface protein masking by the opportunistic fungal pathogen Candida albicans. Infection and Immunity 60:1499-1508.

Hecker L.I., and Sussman A.S. (1973). Activity and heat stability of trehalase from tycelium and ascospores of Neurospora. Journal of Bacteriology 115:582-591.

Hernando F.L., Estevez J.J., Cebrian M., Poulain D., and Ponton J. (1993). Identification of Candida albicans cell wall antigens lost during subculture in synthetic media. Journal of Medical and Veterinary Mycology 31:227-237. 
Horsch M., Mayer C., and Rast D.M. (1996). Stereochemical requirements of chitin synthase for ligand binding at the allosteric site for $\mathrm{N}$-acetylglucosamine. European Journal of Biochemistry 237:476-482.

Ibeas J.I., Yun D.J., Damsz B., Narasimhan M.L., Uesono Y., Ribas J.C., Lee H., Hasegawa P.M., Bressan R.A., and Pardo J.M. (2001). Resistance to the plant PR-5 protein osmotin in the model fungus Saccharomyces cerevisiae is mediated by the regulatory effects of SSD1 on cell wall composition. Plant Journal 25:271-280.

Iranzo M., Aguado C., Pallotti C., Canizares J.V., and Mormeneo S. (2002). The use of trypsin to solubilize wall proteins from Candida albicans led to the identification of chitinase 2 as an enzyme covalently linked to the yeast wall structure. Research in Microbiology 153:227-232.

Iwashita K., Nagahara T., Kimura H., Takano M., Shimoi H., and Ito K. (1999). The bglA gene of Aspergillus kawachii encodes both extracellular and cell wall-bound $\beta$-glucosidases. Applied and Environmental Microbiology 65:5546-5553.

Jacobson E.S. (2000). Pathogenic roles for fungal melanins. Clinical Microbiology Reviews 13:708-822.

Jentoft N. (1990). Why are proteins O-glycosylated. Trends in Biochemical Sciences 15:291-294.

Jigami Y., and Odani T. (1999). Mannosylphosphate transfer to yeast mannan. Biochimica et Biophysica Acta-General Subjects 1426:335-345.

Jones C.L., and Lonergan G.T. (1999). Histochemical detection of laccase in Pycnoporus cinnabarinus using microwave-enhanced colloidal gold microcrystallization. Biotechnology Techniques 13:871-875.

Kapteyn J.C., Montijn R.C., Dijkgraaf G.J.P., and Klis F.M. (1994). Identification of $\beta-1,6-$ glucosylated cell wall proteins in yeast and hyphal forms of Candida albicans. European Journal of Cell Biology 65:402-407.

Kapteyn J.C., Montijn R.C., Dijkgraaf G.J.P., Vandenende H., and Klis F.M. (1995). Covalent association of $\beta$-1,3-glucan with $\beta$-1,6-glucosylated mannoproteins in cell walls of Candida albicans. Journal of Bacteriology 177:3788-3792.

Kapteyn J.C., Montijn R.C., Vink E., delaCruz J., Llobell A., Douwes J.E., Shimoi H., Lipke P.N., and Klis F.M. (1996). Retention of Saccharomyces cerevisiae cell wall proteins through a phosphodiester-linked $\beta$-1,3- $\beta$-1,6-glucan heteropolymer. Glycobiology 6:337-345.

Kapteyn J.C., Ram A.F.J., Groos E.M., Kollar R., Montijn R.C., Vandenende H., Llobell A., Cabib E., and Klis F.M. (1997). Altered extent of cross-linking of $\beta$-1,6-glucosylated mannoproteins to chitin in Saccharomyces cerevisiae mutants with reduced cell wall $\beta-1,3-$ glucan content. Journal of Bacteriology 179:6279-6284.

Kapteyn J.C., Van Den Ende H., and Klis F.M. (1999a). The contribution of cell wall proteins to the organization of the yeast cell wall. Biochimica et Biophysica Acta-General Subjects 1426:373-383. 
Kapteyn J.C., Van Egmond P., Sievi E., Van Den Ende H., Makarow M., and Klis F.M. (1999b). The contribution of the O-glycosylated protein Pir2p/Hsp150 to the construction of the yeast cell wall in wild-type cells and $\beta$-1,6-glucan-deficient mutants. Molecular Microbiology 31:1835-1844.

Kapteyn J.C., Hoyer L.L., Hecht J.E., Muller W.H., Andel A., Verkleij A.J., Makarow M., Van Den Ende H., and Klis F.M. (2000). The cell wall architecture of Candida albicans wild-type cells and cell wall-defective mutants. Molecular Microbiology 35:601-611.

Kelley R. L., and Reddy C. A., (1986a). Identification of glucose oxidase activity as the primary source of hydrogen peroxide production in ligninolytic cultures of Phanerochaete chrysosporium. Archives in Microbiology 144:248-253.

Kelley R. L., and Reddy C. A., (1986b). Purification and characterization of glucose oxidase from ligninolytic cultures of Phanerochaete chrysosporium. Journal of Bacteriology. 166, 269-274

Kersten P.J., Tien M., Kalyanaraman B., and Kirk T.K. (1985). The ligninase of Phanerochaete chrysosporium generates cation radicals from methoxybenzenes. Journal of Biological Chemistry 260:2609-2612.

Khindaria A., Yamazaki I., and Aust S.D. (1995). Veratryl alcohol oxidation by lignin peroxidase. Biochemistry 34:16860-16869.

Khindaria A., Yamazaki I., and Aust S.D. (1996). Stabilization of the veratryl alcohol cation radical by lignin peroxidase. Biochemistry 35:6418-6424.

Kirk T.K., and Farrell R.L. (1987). Enzymatic combustion the microbial degradation of lignin. Annual Review of Microbiology 41:465-505.

Klis F.M. (1994). Cell wall assembly in yeast. Yeast 10:851-869.

Klis F.M., Caro L.H.P., Vossen J.H., Kapteyn J.C., Ram A.F.J., Montijn R.C., VanBerkel M.A.A., and Vandenende H. (1997). Identification and characterization of a major building block in the cell wall of Saccharomyces cerevisiae. Biochemical Society Transactions 25:856860 .

Klis F.M., De Groot P., and Hellingwerf K. (2001). Molecular organization of the cell wall of Candida albicans. Medical Mycology 39:1-8.

Klis F.M., Mol P., Hellingwerf K., and Brul S. (2002). Dynamics of cell wall structure in Saccharomyces cerevisiae. FEMS Microbiology Reviews 26:239-256.

Kobayashi H., Shibata N., and Suzuki S. (1992). Evidence for oligomannosyl residues containing both $\beta-1,2$ and $\alpha-1,2$ linkages as a serotype a specific epitope(s) in mannans of Candida albicans. Infection and Immunity 60:2106-2109. 
Kobayashi H., Tanaka S., Suzuki J., Kiuchi Y., Shibata N., Suzuki S., and Okawa Y. (1997). Amended structure of side chains in a cell wall mannan from Candida albicans serotype A strain grown in yeast extract sabouraud liquid medium under acidic conditions: detection of the branched side chains corresponding to antigenic factor 4. FEMS Microbiology Letters 152:235-242.

Koduri R.S., and Tien M. (1995). Oxidation of guaiacol by lignin peroxidase - role of veratryl alcohol. Journal of Biological Chemistry 270:22254-22258.

Kollar R., Petrakova E., Ashwell G., Robbins P.W., and Cabib E. (1995). Architecture of the yeast cell wall: The linkage between chitin and $\beta$-(1-3)-glucan. Journal of Biological Chemistry 270:1170-1178.

Kollar R., Reinhold B.B., Petrakova E., Yeh H.J.C., Ashwell G., Drgonova J., Kapteyn J.C., Klis F.M., and Cabib E. (1997). Architecture of the yeast cell wall $\beta-(1->6)$-glucan interconnects mannoprotein, $\beta-(1-3)$-glucan, and chitin. Journal of Biological Chemistry 272:17762-17775.

Kuranda M.J., and Robbins P.W. (1991). Chitinase is required for cell separation during growth of Saccharomyces cerevisiae. Journal of Biological Chemistry 266:19758-19767.

Kusamichi M., Monodane T., Tokunaga M., and Koike H. (1990). Influence of surrounding media on preservation of cell wall ultrastructure of Candida albicans revealed by lowtemperature scanning electron-microscopy. Journal of Electron Microscopy 39:477-486.

Lackner R., Srebotnik E., and Messner K. (1991). Oxidative degradation of high molecular weight chlorolignin by manganese peroxidase of Phanerochaete chrysosporium. Biochemical and Biophysical Research Communications 178:1092-1098.

Latgé J.P., and Calderone R. (2006). The fungal cell wall. In: The Mycota, Growth, Differentiation and Sexuality Vol. I, $\mathbf{2}^{\text {nd }}$ edition (Kües and Fischer eds.), Springer-Verlag, Heidelberg, in press.

Law D.T.S., and Segall J. (1988). The Sps100 gene of Saccharomyces cerevisiae is activated late in the sporulation process and contributes to spore wall maturation. Molecular and Cellular Biology 8:912-922.

Leonowicz A., Matuszewska A., Luterek J., Ziegenhagen D., Wojtas-Wasilewska M., Cho N.S., Hofrichter M., and Rogalski J. (1999). Biodegradation of lignin by white rot fungi. Fungal Genetics and Biology 27:175-185.

Lipke P.N., and Kurjan J. (1992). Sexual agglutination in budding yeasts - structure, function, and regulation of adhesion glycoproteins. Microbiological Reviews 56:180-194.

Lipke P.N., and Ovalle R. (1998). Cell wall architecture in yeast: New structure and new challenges. Journal of Bacteriology 180:3735-3740.

LopezRibot J.L., Casanova M., Martinez J.P., and Sentandreu R. (1991). Characterization of cell wall proteins of yeast and hydrophobic mycelial cells of Candida albicans. Infection and Immunity 59:2324-2332. 
LopezRibot J.L., and Chaffin W.L. (1996). Members of the Hsp70 family of proteins in the cell wall of Saccharomyces cerevisiae. Journal of Bacteriology 178:4724-4726.

Lu C.F., Kurjan J., and Lipke P.N. (1994). A pathway for cell wall anchorage of Saccharomyces cerevisiae $\alpha$ agglutinin. Molecular and Cellular Biology 14:4825-4833.

Lu C.F., Montijn R.C., Brown J.L., Klis F., Kurjan J., Bussey H., and Lipke P.N. (1995). Glycosyl phosphatidylinositol-dependent cross-linking of $\alpha$-agglutinin and $\beta$-1,6-glucan in the Saccharomyces cerevisiae cell wall. Journal of Cell Biology 128:333-340.

Lucio A.K.B., Polizeli M.D.T.M., Jorge J.A., and Terenzi H.F. (2000). Stimulation of hyphal growth in anaerobic cultures of Mucor rouxii by extracellular trehalose. Relevance of cell wall bound activity of acid trehalase for trehalose utilization. FEMS Microbiology Letters 182:913.

Manners D.J., Masson A.J., Patterso J.C., Bjorndal H., and Lindberg B. (1973). Structure of a $\beta$ (1-6)-D-glucan from yeast cell walls. Biochemical Journal 135:31-36.

Marcilla A., Elorza M.V., Mormeneo S., Rico H., and Sentandreu R. (1991). Candida albicans mycelial wall structure - supramolecular complexes released by zymolyase, chitinase and $\beta$ mercaptoethanol. Archives of Microbiology 155:312-319.

Martin F., Laurent P., de Carvalho D., Voiblet C., Balestrini R., Bonfante P., and Tagu D. (1999). Cell wall proteins of the ectomycorrhizal basidiomycete Pisolithus tinctorius: Identification, function, and expression in symbiosis. Fungal Genetics and Biology 27:161-174.

Martinez D., Larrondo L.F., Putnam N., Gelpke M.D.S., Huang K., Chapman J., Helfenbein K.G., Ramaiya P., Detter J.C., Larimer F., Coutinho P.M., Henrissat B., Berka R., Cullen D., and Rokhsar D. (2004). Genome sequence of the lignocellulose degrading fungus Phanerochaete chrysosporium strain RP78. Nature Biotechnology 22:695-700.

Mester T., and Field J.A. (1998). Characterization of a novel manganese peroxidase-lignin peroxidase hybrid isozyme produced by Bjerkandera species strain BOS55 in the absence of manganese. Journal of Biological Chemistry 273:15412-15417.

Michalenko G.O., Hohl H.R., and Rast D. (1976). Chemistry and architecture of mycelial wall of Agaricus bisporus. Journal of General Microbiology 92:251-262.

Molloy C., Shepherd M.G., and Sullivan P.A. (1995). Differential extraction of Nacetylglucosaminidase and trehalase from the cell envelope of Candida albicans. Experimental Mycology 19:178-185.

Montijn R.C., Vink E., Muller W.H., Verkleij A.J., Van Den Ende H., Henrissat B., and Klis F.M. (1999). Localization of synthesis of $\beta-1,6$-glucan in Saccharomyces cerevisiae. Journal of Bacteriology 181:7414-7420.

Morris G.J., Winters L., Coulson G.E., and Clarke K.J. (1986). Effect of osmotic stress on the ultrastructure and viability of the yeast Saccharomyces cerevisiae. Journal of General Microbiology 132:2023-2034. 
Moukadiri I., Jaafar L., and Zueco J. (1999). Identification of two mannoproteins released from cell walls of a Saccharomyces cerevisiae mnn1, mnn9 double mutant by reducing agents. Journal of Bacteriology 181:4741-4745.

Mouyna I., Fontaine T., Vai M., Monod M., Fonzi W.A., Diaquin M., Popolo L., Hartland R.P., and Latge J.P. (2000). Glycosylphosphatidylinositol anchored glucanosyl transferases play an active role in the biosynthesis of the fungal cell wall. Journal of Biological Chemistry 275:14882-14889.

Mrsa V., and Tanner W. (1999). Role of NaOH-extractable cell wall proteins Ccw5p, Ccw6p, Ccw7p and Ccw8p (members of the Pir protein family) in stability of the Saccharomyces cerevisiae cell wall. Yeast 15:813-820.

Mulheim A., Waldner R., Sanglard D., Reiser J., Schoemaker H.E., and Leisola M.S.A. (1991). Purification and properties of an aryl alcohol dehydrogenase from the white rot fungus Phanerochaete chrysosporium. European Journal of Biochemistry 195:369-375.

Munoz C., Guillen F., Martinez A.T., and Martinez M.J. (1997). Induction and characterization of laccase in the ligninolytic fungus Pleurotus eryngii. Current Microbiology 34:1-5.

Murgui A., Elorza M.V., and Sentandreu R. (1986). Tunicamycin and papulacandin-B inhibit incorporation of specific mannoproteins into the wall of Candida albicans regenerating protoplasts. Biochimica et Biophysica Acta 884:550-558.

Nerud F., Zouchova Z., and Misurcova Z. (1991). Ligninolytic properties of different white rot fungi. Biotechnology Letters 13:657-660.

Nicole M., Chamberland H., Geiger J.P., Lecours N., Valero J., Rio B., and Ouellette G.B. (1992). Immunocytochemical localization of laccase L1 in wood decayed by Rigidoporus lignosus. Applied and Environmental Microbiology 58:1727-1739.

Notario V., Villa T.G., and Villanueva J.R. (1979). Cell wall associated 1,4- $\beta$-D-xylanase in Cryptococcus albidus characterization of the activity. Journal of General Microbiology 114:415-422.

Notario V. (1982). $\beta$-Glucanases from Candida albicans - Purification, characterization and the nature of their attachment to cell wall components. Journal of General Microbiology 128:747759.

Odds F.C. (1985). Morphogenesis in Candida albicans. CRC Critical Reviews in Microbiology 12:45-93.

Orlean P., Ammer H., Watzele M., and Tanner W. (1986). Synthesis of an O-glycosylated cell surface protein induced in yeast by $\alpha$ factor. Proceedings of the National Academy of Sciences of the United States of America 83:6263-6266. 
Orlean P. (1997). Biogenesis of yeast wall and surface components. In: The molecular and cellular biology of the yeast Saccharomyces. Cell cycle and biology (Pringle J.R., Broach J.R., Jones E.W. eds.) Chapmann and Hall, London, pp. 229-262.

Osumi M. (1998). The ultrastructure of yeast: Cell wall structure and formation. Micron 29:207233.

Pardo M., Monteoliva L., Pla J., Sanchez M., Gil C., and Nombela C. (1999). Two-dimensional analysis of proteins secreted by Saccharomyces cerevisiae regenerating protoplasts: A novel approach to study the cell wall. Yeast 15:459-472.

Pease E.A., Andrawis A., and Tien M. (1989). Manganese dependent peroxidase from Phanerochaete chrysosporium primary structure deduced from cDNA Sequence. Journal of Biological Chemistry 264:13531-13535.

Pitson S.M., Seviour R.J., and McDougall B.M. (1999). Intracellular and cell wall associated $\beta$ glucanases and $\beta$-glucosidases of Acremonium persicinum. Mycological Research 103:12171224.

Ponton J., and Jones J.M. (1986). Analysis of cell wall extracts of Candida albicans by sodium dodecyl sulfate polyacrylamide gel electrophoresis and western blot techniques. Infection and Immunity 53:565-572.

Poulain D., Tronchin G., Dubremetz J.F., and Biguet J. (1978). Ultrastructure of cell wall of Candida albicans blastospores - study of its constitutive layers by use of a cytochemical technique revealing polysaccharides. Annales de Microbiologie A129:141-152.

Ram S.P., Romana L.K., Shepherd M.G., and Sullivan P.A. (1984). Exo-(1-3)- $\beta$-glucanase, autolysin and trehalase activities during yeast growth and germ tube formation in Candida albicans. Journal of General Microbiology 130:1227-1236.

Rast D.M., Horsch M., Furter R., and Gooday G.W. (1991). A complex chitinolytic system in exponentially growing mycelium of Mucor rouxii - properties and function. Journal of General Microbiology 137:2797-2810.

Rast D.M., Baumgartner D., Mayer C., and Hollenstein G.O. (2003). Cell wall associated enzymes in fungi. Phytochemistry 64:339-366.

Renganathan V., and Gold M.H. (1986). Spectral characterization of the oxidized states of lignin peroxidase an extracellular heme enzyme from the white rot basidiomycete Phanerochaete chrysosporium. Biochemistry 25:1626-1631.

Reverberi M., Di Mario F., and Tomati U. (2004). $\beta$-Glucan synthase induction in mushrooms grown on olive mill wastewaters. Applied Microbiology and Biotechnology 66:217-225.

Reynolds T.B., and Fink G.R. (2001). Bakers' yeast, a model for fungal biofilm formation. Science 291:878-881. 
Rodriguez-Pena J.M., Cid V.J., Arroyo J., and Nombela C. (2000). A novel family of cell wall related proteins regulated differently during the yeast life cycle. Molecular and Cellular Biology 20:3245-3255.

Ruel K., and Joseleau J.P. (1991). Involvement of an extracellular glucan sheath during degradation of populus wood by Phanerochaete chrysosporium. Applied and Environmental Microbiology 57:374-384.

Ruel K., Joseleau J.P., Cochaux A., Doignie J.C., and Poustis J. (2003). Enzymatic treatments to restore recycled fibres properties. Appita Journal 56:242-242.

Ruiz-Herrera J. (1992). Chemical composition of the fungal cell wall. In: Fungal Cell Wall: Structure, Synthesis, and Assembly. (Ruiz-Herrera J. ed.), CRC Press, Boca Raton, pp. 5-22.

Ruiz-Herrera J., Mormeneo S., Vanaclocha P., Fontdemora J., Iranzo M., Puertes I., and Sentandreu R. (1994). Structural organization of the components of the cell wall from Candida albicans. Microbiology-Uk 140:1513-1523.

Ruiz-Herrera J., Martinez A.I., and Sentandreu R. (2002). Determination of the stability of protein pools from the cell wall of fungi. Research in Microbiology 153:373-378.

Sanjuan R., Zueco J., Stock R., Demora J.F., and Sentandreu R. (1995). Identification of glucan mannoprotein complexes in the cell wall of Candida albicans using a monoclonal antibody that reacts with a (1,6)- $\beta$-glucan epitope. Microbiology-Uk 141:1545-1551.

Sanjuan R., Zueco J., Perez J., Penarroja C., and Sentandreu R. (1996). A comparative study of the incorporation of a 1,6- $\beta$-glucan and an O-glycosylated protein epitope into the cell wall of Candida albicans. Microbiology-Uk 142:2255-2262.

Sassoon J., and Mooibroek H. (2001). A system of categorizing enzyme-cell wall associations in Agaricus bisporus, using operational criteria. Applied Microbiology and Biotechnology 56:613-622.

Scherrer R., Louden L., and Gerhardt P. (1974). Porosity of yeast cell wall and membrane. Journal of Bacteriology 118:534-540.

Schreuder M.P., Brekelmans S., Vandenende H., and Klis F.M. (1993). Targeting of a heterologous protein to the cell wall of Saccharomyces cerevisiae. Yeast 9:399-409.

Sietsma J.H., Rast D., and Wessels J.G.H. (1977). Effect of carbon dioxide on fruiting and on degradation of a cell wall glucan in Schizophyllum commune. Journal of General Microbiology 102:385-389.

Sietsma J.H., and Wessels J.G.H. (2006). Apical wall biogenesis. In: The Mycota, Growth, Differentiation and Sexuality $\mathbf{2}^{\text {nd }}$ Edition (Kües U., Fischer R. eds.), Springer-Verlag, Berlin Heidelberg, pp. 261-290.

Smail E.H., and Jones J.M. (1984). Demonstration and solubilization of antigens expressed primarily on the surfaces of Candida albicans germ tubes. Infection and Immunity 45:74-81. 
Smith A.E., Zhang Z.B., Thomas C.R., Moxham K.E., and Middelberg A.P.J. (2000). The mechanical properties of Saccharomyces cerevisiae. Proceedings of the National Academy of Sciences of the United States of America 97:9871-9874.

Srebotnik E., and Messner K. (1998). Determination of the accessibility of lignocellulosic substrates to enzymatic degradation by immunoelectron microscopy. In: Institute of Physics Conference Series No. 93/3 Dickinson H.G., Goodhew P.J. (eds) EUREM 88. Bristol, Philadelphia:, pp 107108

Sundaramoorthy M., Kishi K., Gold M.H., and Poulos T.L. (1994). The crystal structure of manganese peroxidase from Phanerochaete chrysosporium at 2.06-angstrom resolution. Journal of Biological Chemistry 269:32759-32767.

Sundstrom P.M., and Kenny G.E. (1985). Enzymatic release of germ tube specific antigens from cell walls of Candida albicans. Infection and Immunity 49:609-614.

Sundstrom P.M., Nichols E.J., and Kenny G.E. (1987). Antigenic differences between mannoproteins of germ tubes and blastospores of Candida albicans. Infection and Immunity 55:616-620.

Surarit R., Gopal P.K., and Shepherd M.G. (1988). Evidence for a glycosidic linkage between chitin and glucan in the cell wall of Candida albicans. Journal of General Microbiology 134:1723-1730.

Teunissen A.W.R.H., and Steensma H.Y. (1995). Review - the dominant flocculation genes of Saccharomyces cerevisiae constitute a new subtelomeric gene family. Yeast 11:1001-1013.

Thurston C.F. (1994). The structure and function of fungal laccases. Microbiology-Uk 140:19-26.

Tien M., and Kirk T.K. (1984). Lignin degrading enzyme from Phanerochaete chrysosporium purification, characterization, and catalytic properties of a unique $\mathrm{H}_{2} \mathrm{O}_{2}$ requiring oxygenase. Proceedings of the National Academy of Sciences of the United States of America-Biological Sciences 81:2280-2284.

Tien M., Kirk T.K., Bull C., and Fee J.A. (1986). Steady state and transient state kinetic studies on the oxidation of 3,4-dimethoxybenzyl alcohol catalyzed by the ligninase of Phanerochaete chrysosporium burds. Journal of Biological Chemistry 261:1687-1693.

Tohe A., Yasunaga S., Nisogi H., Tanaka K., Oguchi T., and Matsui Y. (1993). 3 Yeast Genes, Pir1, Pir2 and Pir3, containing internal tandem repeats, are related to each other, and Pir1 and Pir2 are required for tolerance to heat-shock. Yeast 9:481-494.

Tuor U., Wariishi H., Schoemaker H.E., and Gold M.H. (1992). Oxidation of phenolic arylglycerol $\beta$ aryl ether lignin model compounds by manganese peroxidase from Phanerochaete chrysosporium oxidative cleavage of an alpha carbonyl model compound. Biochemistry 31:4986-4995.

Tuor U., Winterhalter K., and Fiechter A. (1995). Enzymes of white rot fungi involved in lignin degradation and ecological determinants for wood decay. Journal of Biotechnology 41:1-17. 
van der Vaart J.M., vanSchagen F.S., Mooren A.T.A., Chapman J.W., Klis F.M., and Verrips C.T. (1996). The retention mechanism of cell wall proteins in Saccharomyces cerevisiae. Wall bound Cwp2p is $\beta-1,6$-glucosylated. Biochimica et Biophysica Acta-General Subjects 1291:206-214.

Waldner R., Leisola M.S.A., and Fiechter A. (1988). Comparison of ligninolytic activities of selected white rot Fungi. Applied Microbiology and Biotechnology 29:400-407.

Walser P.J., Velagapudi R., Aebi M., and Kües U. (2003). Extracellular matrix proteins in mushroom development. Rec. Res. Devel. Microbiol 7: 381-415.

Walser P.J., Haebel P.W., Kunzler M., Sargent D., Kües U., Aebi M., and Ban N. (2004). Structure and functional analysis of the fungal galectin CGL2. Structure 12:689-702.

Walser P.J., Kües U., Aebi M., and Kunzler M. (2005). Ligand interactions of the Coprinopsis cinerea galectins. Fungal Genetics and Biology 42:293-305.

Wariishi H., Akileswaran L., and Gold M.H. (1988). Manganese peroxidase from the basidiomycete Phanerochaete chrysosporium spectral characterization of the oxidized states and the catalytic cycle. Biochemistry 27:5365-5370.

Wariishi H., Valli K., and Gold M.H. (1989). Oxidative cleavage of a phenolic diarylpropane lignin model dimer by manganese peroxidase from Phanerochaete chrysosporium. Biochemistry 28:6017-6023.

Watzele M., Klis F., and Tanner W. (1988). Purification and characterization of the inducible A agglutinin of Saccharomyces cerevisiae. EMBO Journal 7:1483-1488.

Weber R.W.S., and Pitt D. (1997). Purification characterization and exit routes of two acid phosphatases secreted by Botrytis cinerea. Mycological Research 101:1431-1439.

Wessels J.G.H., and Sietsma J.H. (1979). Wall structure and growth in Schizophyllum commune. In: Fungal wall and hyphal growth. (Bentik J.N., Trinci A.P.J. eds), Cambridge University Press, pp. 27-48.

Whittaker M.M., Kersten P.J., Nakamura N., SandersLoehr J., Schweizer E.S., and Whittaker J.W. (1996). Glyoxal oxidase from Phanerochaete chrysosporium is a new radical-copper oxidase. Journal of Biological Chemistry 271:681-687.

Whittaker M.M., Kersten P.J., Cullen D., and Whittaker J.W. (1999). Identification of catalytic residues in glyoxal oxidase by targeted mutagenesis. Journal of Biological Chemistry 274:36226-36232.

Wösten H.A.B. (2001). Hydrophobins: Multipurpose proteins. Annual Review of Microbiology 55:625-646.

Youngs H.L., Moenne-Loccoz P., Loehr T.M., and Gold M.H. (2000). Formation of a bis(histidyl) heme iron complex in manganese peroxidase at high $\mathrm{pH}$ and restoration of the native enzyme structure by calcium. Biochemistry 39:9994-10000. 
Yu L., Lee K.K., Ens K., Doig P.C., Carpenter M.R., Staddon W., Hodges R.S., Paranchych W., and Irvin R.T. (1994). Partial characterization of a Candida albicans fimbrial adhesin. Infection and Immunity 62:2834-2842.

Yun D.J., Zhao Y., Pardo J.M., Narasimhan M.L., Damsz B., Lee H., Abad L.R., Durzo M.P., Hasegawa P.M., and Bressan R.A. (1997). Stress proteins on the yeast cell surface determine resistance to osmotin, a plant antifungal protein. Proceedings of the National Academy of Sciences of the United States of America 94:7082-7087.

Zhu X.D., Gibbons J., Garcia-Rivera J., Casadevall A., and Williamson P.R. (2001). Laccase of Cryptococcus neoformans is a cell wall-associated virulence factor. Infection and Immunity 69:5589-5596.

Zhu X.D., and Williamson P.R. (2003). A CLC-type chloride channel gene is required for laccase activity and virulence in Cryptococcus neoformans. Molecular Microbiology 50:1271-1281.

Zlotnik H., Fernandez M.P., Bowers B., and Cabib E. (1984). Saccharomyces cerevisiae mannoproteins form an external cell wall layer that determines wall porosity. Journal of Bacteriology 159:1018-1026. 
Disruption of cell walls and isolation of cell wall proteins from the white rot basidiomycete Trametes versicolor 



\section{Disruption of cell walls and isolation of cell wall proteins from the white rot basidiomycete Trametes versicolor}

\subsection{Abstract}

The fungal cell wall is the outer most layer of the hypha. It plays an important role as a physical and chemical barrier between the cell and its surrounding environment. In addition, it actively participates in numerous physiological processes. An effective method for disruption of hyphae from Trametes versicolor was established at the temperature of liquid nitrogen to obtain pure cell walls. Isolated cell walls were free of intracellular enzymatic activities. Non-covalently bound proteins were released from the cell wall samples and analyzed by gel-electrophoresis. More than 400 visible different protein spots were encountered on 2-D gels. These proteins were mostly in the near neutral pI range (pI 6.0 to 8.0 ) and sized between $10-100 \mathrm{kDa}$.

\subsection{Introduction}

The fungal cell wall plays an important role in shielding the cell against osmotic, chemical and biological injury. It is involved in physiological processes such as growth and morphogenesis, and in interaction with the surrounding environment, cell-adhesion and cell-cell interaction (Gooday 1995). The fungal cell wall is a complex of macromolecules that envelopes the cell external to the plasma membrane. The main components are $\alpha$ - and $\beta$-glucans, chitin, glycoproteins, chitosan, polyuronids, inorganic salts, and pigments. The skeletal polysaccharides such as glucans and chitin comprise approx. $80 \%$ of the dry matter, and the protein content varies typically from $3 \%$ to $20 \%$. Between different fungi and between different cell types of a fungus, the amounts of these cell wall constituents can vary (Ruiz-Herrera 1992; Latge and Calderone 2005; Sietsma and Wessels 2006).

Abbreviations: PCWF (purified cell wall fraction), CWF (cell wall fraction). CHAPS (3,3cholamidopropyldimethylammonio-1-propanesulfonate), DTT (dithiothreitol), EDTA (ethylenediaminetetraacetic acid), G6PD (glucose-6-phosphatase dehydrogenase), ICD (isocitrate dehydrogenase), and MDH (malate dehydrogenase). 
Individual cell wall components may be released from intact cells or from harvested cell walls. A particular challenge is to isolate and identify the cell wall proteome. In the ascomycetous yeasts, certain chemical treatments will free the non-covalently and covalently bound surface proteins which are attached by disulphide bonds. Enzymatic methods have been established for isolation of glycoproteins from intact cells. Various lytic enzymes such as cellulases, $\beta$-glucanases and chitinases, and mixtures of them are commercially available. $\beta-1,3-$ and $\beta-1,6$-glucanases for example will both help to specifically release some of the Pir-proteins (proteins attached to the cell wall matrix by ß-1,3-glucan), and GPI (proteins attached to the cell wall matrix by $\beta-1,6$-glucan)anchored proteins (Kapteyn et al. 1996). Mixtures of enzymes or sequential treatment with different enzymes will enhance the overall yields of released proteins (Kapteyn et al. 1997; 1999).

Unfortunately, enzymatic methods from yeasts are not generally applicable to other fungi because of different chemical compositions and a comparably more complex structure of the cell walls (Ruiz-Herrera 1992; Sietsma and Wessels 2006). Fungal protoplasting shows that disintegration of cell walls from fungal mycelia can principally be achieved by certain cost-effective enzyme mixtures such as Novozyme 234 or Zymolase 20T (Specht et al. 1991; Honda et al. 2000). However, such treatment will introduce unwanted proteins into a sample of study hindering subsequent analysis of cell wall proteins. Moreover, proteolytic activities are usually present in such crude enzyme preparations (Roncal et al. 1991), which will result in digestion of any released cell wall fraction (CWF) proteins. Cell wall mannoproteins were isolated from whole yeast cells of dimorphic ascomycetes Penicillium marneffei by the treatment of glucanase and Bmercaptoethanol (Cao et al. 1998). In Aspergillus fumigatus, purified recombinant glucanases have successfully been applied to release tightly bound proteins from the cell walls a filamentous ascomycetes (Bernard et al. 2001). From Fusarium oxysporium, cell wall proteins have been released by the treatment of $\beta-1,3$-glucanase suggesting that a part of the cell wall proteins is covalently bound to $\beta-1,3$-glucan (Schoffelmeer et al. 
2001). At least seven proteins were removed by chemical treatment from Aspergillus niger cell walls (Damveld et al. 2005).

Generally, to avoid contamination with cytoplasmic proteins when wanting to analyse the cell wall proteome of a fungus, it is advisable to first isolate the cell wall fraction. Furthermore, when broken into smaller pieces by the sample preparation method the isolated cell walls promise better extraction of cell wall proteins rather than whole cells for the same purpose. Cell disruption can be achieved by the use of mechanical shear forces in liquid and solid media. Commonly applied mechanical methods use homogenization of the fresh material with glass beads in a high speed homogenizer or a shaker (Kang et al. 1984; Angiolella et al. 2002; Bernard et al. 2002; Iranzo et al. 2002). These methods were applied for the disruption of mycelium from e.g. Neurospora crassa (Cramer et al. 1983) and Verticillium fungicola (Calonje et al. 2000).

Little is found in the literature on breaking hyphae of higher basidiomycetes. There is no general technique, which can be applied to obtain fine disrupted cell wall fractions. Work by Taubert et al. (2000) showed that the rigid cell walls of higher basidiomycetes are not easily disrupted by methods that have successfully applied to ascomycetes. These authors successfully tested several different types of homogenizers in breaking cells. Only a precussion grinder with glass beads gave acceptable result with mycelium from Ganoderma applanatum and Pycnoporus cinnabarinus. A homogenizer with glass-beads was also effectively used for cell breaking of Agaricus bisporus (Sassoon et al. 2001). However, since heat develops during the treatment, the applied methods will not result in a material suitable for isolation of proteins in their native form. Other methods for effective and quantitative cell disruption are therefore required with vigorous mechanical forces that should operate at a low temperature.

The present study describes a very effective method of breaking of fungal hypha from the wood degrading basidiomycete Trametes versicolor and isolation of purified cell walls at a temperature of liquid nitrogen. 


\subsection{Materials and methods}

\section{Fungal cultures}

T. versicolor strain number 6 and Pleurotus ostreatus strain number 8 from the collection of the Institute of Forest Botany, Georg August Universität, Göttingen, was cultivated on basidiomycetes-medium (BSM, Hüttermann and Volger, 1973) with 1.5\% agar. Starter liquid cultures were prepared by inoculation of $100 \mathrm{ml}$ BSM liquid medium in $500 \mathrm{ml}$ conical flasks with three agar pieces $(1 \mathrm{~cm}$ in diameter) of the stock culture and cultivated stationary at $25^{\circ} \mathrm{C}$ in the dark. Mycelium of 14 days-old liquid cultures was gently disrupted using an Ultra-Turrax T25 (rod diameter 10 mm; Janke \& Kunkel, IKALabortechnik, Germany) at 9,000 rpm for 1 minute under sterile conditions. Each $4 \mathrm{ml}$ of mycelium suspension were used to inoculate new $100 \mathrm{ml}$ BSM liquid cultures. The main cultures were incubated stationary for $14 \mathrm{~d}$ at $25^{\circ} \mathrm{C}$ in the dark. 14 days old mycelia of $T$. versicolor were harvested by vacuum filtration with $90 \mathrm{~mm}$ diameter filter (595 Round filter, Ø $90 \mathrm{~mm}$, Schleicher \& Micro Science GmbH, Germany) and washed twice with $2-5 \mathrm{ml}$ of distilled water. Collected mycelia were frozen at $-20^{\circ} \mathrm{C}$ and lyophilized $(2 \mathrm{~g}$ of fresh material corresponding to approx. $200 \mathrm{mg}$ dry weight). Culture supernatants were frozen at $-20^{\circ} \mathrm{C}$ until further use. Similarly, non-induced cultures from $P$. ostreatus were obtained and the experiments were performed in four to five replicates.

\section{Grinding of mycelium}

Using mortar and pestle: Each $200 \mathrm{mg}$ of dried mycelium were added to a mortar chilled in liquid nitrogen. The samples were ground manually for about 10-15 minutes while permanently suspended in a small volume of liquid nitrogen.

Using Ultra-Turrax: Each $200 \mathrm{mg}$ of dried mycelium were added to approximately 100 $\mathrm{ml}$ of liquid nitrogen in a $200 \mathrm{ml}$ Schott glass bottle and homogenized using a rod of 10 $\mathrm{mm}$ in diameter at 24,000 rpm (Ultra-Turrax T25, Janke \& Kunkel, IKA-Labortechnik, Germany). Grinding was performed for a total of $15 \mathrm{~min}$. If necessary, liquid nitrogen was added to maintain a constant volume.

Using a bead beater: $2 \mathrm{~g}$ fresh weight of mycelium was taken in a $15 \mathrm{ml}$ container of the bead beater (BSP Bead Beater, Model 1107900, Biospec Products Inc., Bartlesville, 
USA). $0.5 \mathrm{~mm}$ glass beads were filled into the container up to the brim and cell breaking buffer was added (CBB; Lim et al. 2001). The whole assembly was pre-cooled on ice for 30 minutes till a temperature of $4^{\circ} \mathrm{C}$ was achieved. Three grinding cycles each of 3-4 minutes were carried out in the bead beater, interrupted by repeated cooling of the samples for 30 minutes on ice.

Using a ball mill: Two methods using a horizontally oscillating mill (Mixer Mill 2000, Retsch, Haan, Germany) were applied to grind lyophilized fungal mycelia. In the first method, $50 \mathrm{mg}$ of samples corresponding to a volume of $100 \mu \mathrm{l}$ were placed in $1.5 \mathrm{ml}$ plastic micro tubes (Sarstedt, Nümbrecht, Germany) together with two tungsten carbide balls ( $3 \mathrm{~mm}$ in diameter). After freezing in liquid nitrogen, each five microtubes were placed into a five position PTFE-adapter (5 reaction vials) and the samples ground for 5 min at the maximum amplitude setting. Thereafter, the microtubes were immersed in liquid nitrogen and grinding was repeated for three more times. In the second approach, $200 \mathrm{mg}$ of mycelium were placed in a chilled $25 \mathrm{ml}$ stainless steel jar (grinding jar, $25 \mathrm{ml}$, Retsch, Haan, Germany) with a stainless steel ball (20 $\mathrm{mm}$ in diameter). The samples were further chilled for a few minutes in liquid nitrogen before grinding them at the amplitude setting of 80 (Mixer Mill 2000, Retsch, Haan, Germany) in three consecutive steps of 5 minutes each with chilling in liquid nitrogen in between.

After grinding, the still frozen material from all methods was suspended in $10 \mathrm{ml}$ of cell breaking buffer (CBB; Lim et al. 2001) [0.2 M NaCl, $20 \mathrm{mM}$ Tris, $2 \mathrm{mM}$ EDTA, 0.01\% Tween 80 , and $1 \mathrm{mM}$ phenylmethanesulfonyl fluoride (PMSF)] and transferred into 50 $\mathrm{ml}$ plastic tubes (Sarstedt, Nümbrecht, Germany).

\section{Purification of cell walls}

Approximately $200 \mathrm{mg}$ of ground mycelia were suspended in $10 \mathrm{ml} \mathrm{CBB}$ and transferred to centrifuge tubes. The samples were centrifuged at $650 \mathrm{~g}$ at $4^{\circ} \mathrm{C}$ for $10 \mathrm{~min}$. The pellet was washed with $10 \mathrm{ml}$ ice-cold CBB (first washing step) and re-suspended in $10 \mathrm{ml}$ icecold CBB (second washing step). The solution was bedded onto $30 \mathrm{ml}$ of $30 \%$ sorbitol and centrifuged at $650 \mathrm{~g}$ for $20 \mathrm{~min}$ to separate cytoplasmic organelles from the cell wall 
fraction (third washing step). The cell wall fraction was washed again with $30 \mathrm{ml}$ of icecold $\mathrm{CBB}$, centrifuged for $10 \mathrm{~min}$ at $3200 \mathrm{~g}$ at $4{ }^{\circ} \mathrm{C}$ (fourth washing step) and finally washed with $30 \mathrm{ml}$ of distilled ice-cold water with $1 \mathrm{mM}$ PMSF (fifth washing step). The precipitated cell wall fraction $(\mathrm{CWF})$ was lyophilized and stored at $-20^{\circ} \mathrm{C}$. Aliquots of the supernatants of all washing steps were used for measurement of cytoplasmic markers and total protein.

\section{Scanning electron microscopy and energy-dispersive X-ray microanalysis}

The quality of purified cell wall preparation was observed using a light microscope and a scanning electron microscope (SEM). SEM-samples were prepared by gold plating using a Emscope gold coating machine for sample preparation (Super coter SC $500 \mathrm{M}$ ) and the images were obtained at $20 \mathrm{KV}$ (Phillips 5.15). Presence of metal particles in the samples was analyzed by energy-dispersive X-ray microanalysis (EDAX).

\section{Assays of enzyme activities in washing solutions and purified cell wall fractions}

To check the presence of cytosolic proteins, activities of glucose-6-phosphate dehydrogenase (G6PD), isocitrate dehydrogenase (IDH), and malate dehydrogenase (MDH) were measured following the protocols of Langdon et al. (1966) and Sassoon et al. (2001), using either $10 \mathrm{mg}$ (G6PD) or $50 \mathrm{mg}$ (IDH and MDH) of wet weight of purified CWF or 10-200 $\mu 1$ aliquots of washing solutions. The cell wall samples were incubated for 10-15 minutes in the corresponding reagent solutions and centrifuged for $20 \mathrm{~s}$ at $10,000 \mathrm{~g}$ to remove the cell walls. Changes of absorption in the supernatant were measured at $340 \mathrm{~nm}$. Enzyme activities were calculated as a difference of absorbance between a sample and a blank control. The cell wall associated enzyme activities were expressed per $g$ of dry weight purified CWF. Enzymatic activities in the washing solutions were measured kinetically over a period of $15 \mathrm{~min}$. Laccase activity was qualitatively measuredin $10 \mathrm{mg}$ of purified the CWF by addition of $100 \mu \mathrm{l} 50 \mathrm{mM}$ ABTS in $900 \mu 1$ of $100 \mathrm{mM}$ sodium acetate buffer pH 5.0 (Matsumura et al. 1986). 


\section{Protein extraction and quantification}

The non-covalently bound proteins of CWFs were extracted from $10 \mathrm{mg}$ samples by boiling the samples for $10 \mathrm{~min}$ in $1 \mathrm{ml}$ protein extraction buffer (PE-buffer; $60 \mathrm{mM}$ Tris$\mathrm{HCl} \mathrm{pH}$ 6.8, $50 \mathrm{mM}$ EDTA, 2\% SDS, 0.5\% $\beta$-mercaptoethanol; Masuoka et al. 2002). After centrifugation for $5 \mathrm{~min}$ at $10,000 \mathrm{~g}$, the supernatant was harvested and the remaining cell wall pellet was extracted three more times as described above. All four extracts were combined and the total protein amount in the samples was determined by the modified Lowry method (Peterson 1977) using bovine serum albumin (BSA) as a standard. Protein was precipitated by four volumes of $10 \%$ trichloroacetic acid (TCA) in acetone (w/v) from aliqouts of extracts with desired protein amounts (Damerval et al. 1986) and precipitates were kept at $-20^{\circ} \mathrm{C}$ over night. Protein pellets were collected by centrifugation at $16,000 \mathrm{~g}$ for $20 \mathrm{~min}$, washed four times with acetone to remove TCA and air dried.

For analysis of proteins secreted into the medium, culture supernatants and cytoplasmic fractions were centrifuged for $20 \mathrm{~min}$ at $3,200 \mathrm{~g}$ and $4^{\circ} \mathrm{C}$. After determination of protein concentrations by the modified Lowry method, proteins were precipitated by $10 \%$ TCAacetone from supernatant aliquots containing to $50-100 \mu \mathrm{g}$ protein.

\section{D and 2D gel electrophoresis}

1D-SDS-PAGE electrophoresis was performed using $12 \times 12 \mathrm{~cm}$ discontinuous $12 \%$ acrylamide gels with $0.025 \mathrm{M}$ Tris base, $\mathrm{pH} 8.3$ as electrode buffer (Laemmli 1970). Protein samples were mixed in sample buffer (0.06 M Tris-Cl, pH 6.8, 10\% glycerol, $0,025 \%$ bromphenol blue). $20 \mu 1$ samples with $1 \mu \mathrm{g} / \mu 1$ protein were loaded and run at 10 $15^{\circ} \mathrm{C}$ at a constant current of $30 \mathrm{~mA}$.

For 2D-electrophoresis, protein samples were dissolved in loading buffer [8 $\mathrm{M}$ urea, 4\% (w/v) CHAPS, $50 \mathrm{mM}$ DTT, 5\% (v/v) Triton X100, 0,67\% (v/v) Ampholyte buffer (Amersham Biosciences)]. $350 \mu \mathrm{l}$ of sample solution containing approximately $100 \mu \mathrm{g}$ protein was loaded on $18 \mathrm{~cm}$ IPG-strips, $\mathrm{pH}$ range 3-10 (Amersham Biosciences) in ceramic holders, rehydrated and focused using an Ettan IPGphor isoelectric focusing 
machine (Amersham) for a total of $46,000 \mathrm{Vhr}$ at $15^{\circ} \mathrm{C}$ with the following settings: 100 $\mu \mathrm{A}$ per strip, (12 hr, $20 \mathrm{~V}$, step-n-hold), $200 \mathrm{~V}$ (1hr), $500 \mathrm{~V}$ (1hr), 1,000 Vhr, 8,000 Vhr $(8,000 \mathrm{~V}), 40000 \mathrm{Vhr}(8,000 \mathrm{~V})$, all according to the protocol of the manufacture. In the $2^{\text {nd }}$ dimension, proteins were separated on $12 \%$ PAGE using Ettan DALTsix electrophoresis chamber (Amersham) together with a protein marker (Precision Protein Marker, Biorad, 10-250 kDa). After separation of the proteins at $10^{\circ} \mathrm{C}$ for $5.5 \mathrm{hr}$ at (step1: $600 \mathrm{~V}, 400 \mathrm{~mA}$ for $30 \mathrm{~min}$, step-2: $3000 \mathrm{~V}, 400 \mathrm{~mA}, 100 \mathrm{~W}$ for $5 \mathrm{hrs}$ ), the gels were fixed in $30 \%$ methanol with $12 \%$ acetic acid and $0.05 \%$ formaldehyde overnight and subsequently stained with silver (Blum et al. 1987).

\subsection{Result and Discussion}

\subsubsection{Establishing an efficient method for isolating highly purified CWF from fungal mycelium}

In this study, several methods were tested for breaking the cells of the filamentous fungus $T$. versicolor in order to isolate purified cell walls. Manual breaking of mycelia using mortar and pestle with liquid nitrogen for 10-20 min was inconsistent by the difficulty to apply constant manual forces in the different grindings. Broken mycelia aggregated into flocks in sizes reaching hundred and more $\mu \mathrm{m}$ in diameter (Fig. 1B and Fig. 2). SEM pictures showed that several unbroken hyphae of up to $>40 \mu \mathrm{m}$ in length were present in a matrix of cellular material (Fig. 1).

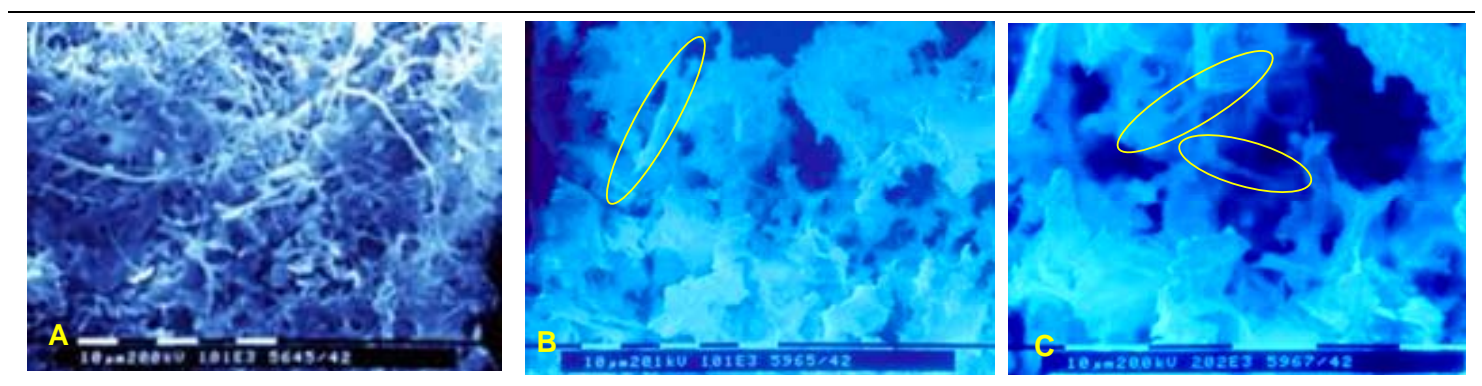

Fig. 1. Manual grinding of mycelium from T. versicolor: SEM pictures of the mycelia of T. versicolor before (A) and partially broken mycelium after grinding $(\mathbf{B}, \mathbf{C})$. The highlighted area in (B) shows hyphae of more than $40 \mu \mathrm{m}$ in length. Similar unbroken hyphae can be seen in (C). 

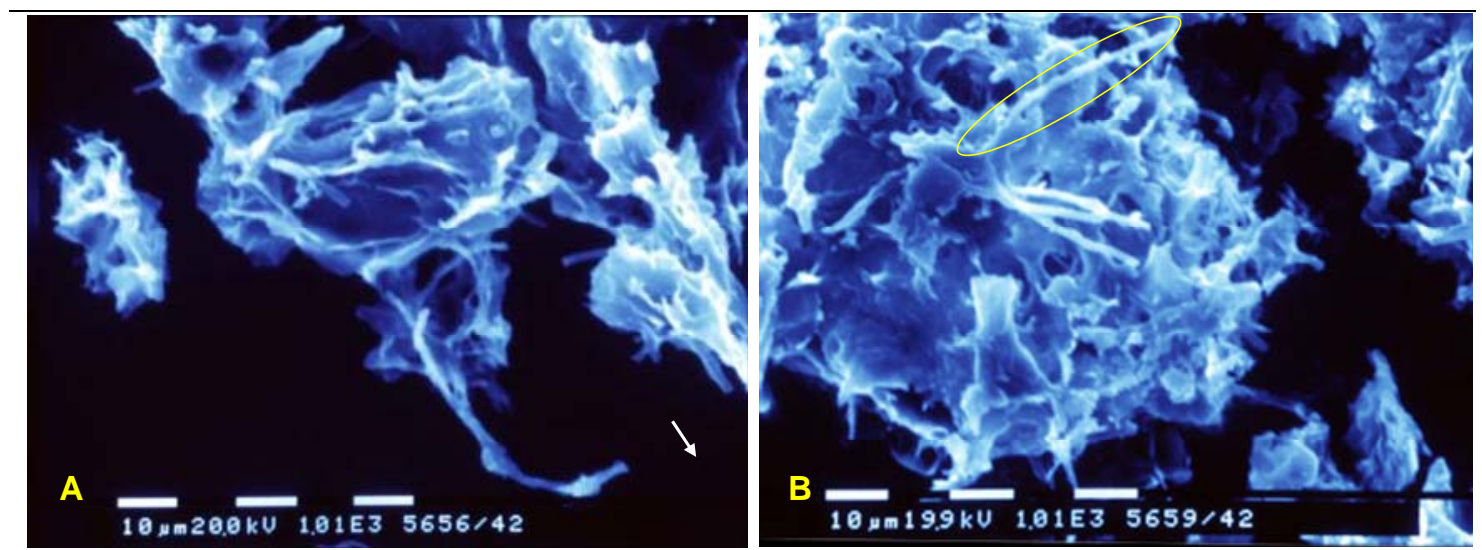

Fig. 2. Manual grinding of mycelium from T. versicolor: SEM pictures of the partially broken mycelium of $T$. versicolor after grinding. The highlighted area in (B) shows hyphae of more than $40 \mu \mathrm{m}$ in length.

When using an Ultra-Turrax, the results were similarly unsatisfying. Several longer pieces of unbroken hyphae were present in the flocks among aggregated small hyphal pieces (not shown), confirming earlier findings by Taubert et al. (2000) obtained with mycelium of Ganoderma applanatum and Pycnoporus cinnabarinus.

In a bead beater, one of the most commonly used instrument for cell disruption in yeasts (Kang et al. 1984), after treatment of pre-cooled samples in cell breaking buffer up to 10$15 \mathrm{~min}$, the mycelium was ruptured into pieces within a few minutes. However, also here hyphae were only partially broken (Fig. 3). The procedure generated a high amount of heat which increased the sample temperature form $4^{\circ} \mathrm{C}$ to $>75^{\circ} \mathrm{C}$ within 3 minutes of grinding.
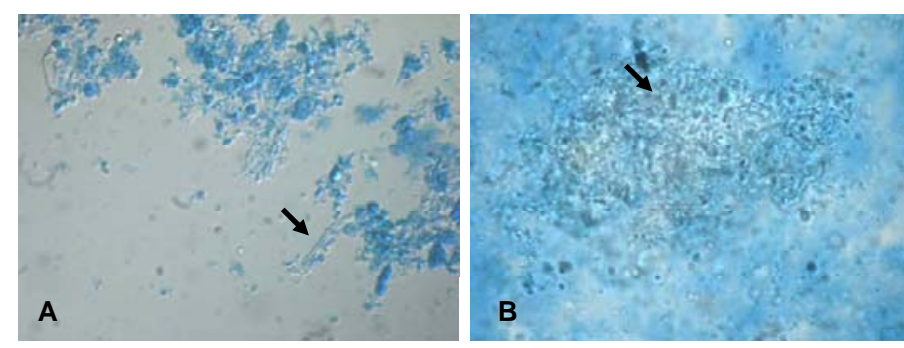

Fig. 3. Light microscope pictures of mycelia of $T$. versicolor ground for $3(\mathbf{A})$ and $10 \mathrm{~min}(\mathbf{B})$ in a bead beater. Arrows mark long unbroken hyphae. The size of hyphal fragments corresponds to $26.8 \pm 5.3 \mu \mathrm{m}$ (measured for seven hyphal fragments) (B).

Grinding mycelia for 20 minutes in $1.5 \mathrm{ml}$ conical plastic micro tubes with two tungsten carbide balls ( $3 \mathrm{~mm}$ in diameter) using a ball mill in four consecutive cycles of $5 \mathrm{~min}$ each and keeping in between the microtubes in liquid nitrogen for 2-3 minutes to 
maintain a low temperature did not give a satisfactory amount of cell breaking. Several hyphal fragments measuring more than $30 \mu \mathrm{m}$ (measured for nine fragments) in length remained (Fig. 4).

Fig. 4. SEM pictures of mycelia of $T$. versicolor ground in micro tubes using a ball mill, for $5 \min (\mathbf{A}), 10$ $\min (\mathbf{B}), 15 \min (\mathbf{C})$, and 20 min (D). All SEM pictures show the presence of long and unbroken mycelia of $>30 \mu \mathrm{m}$ in length (represented by the highlighted areas in the pictures).
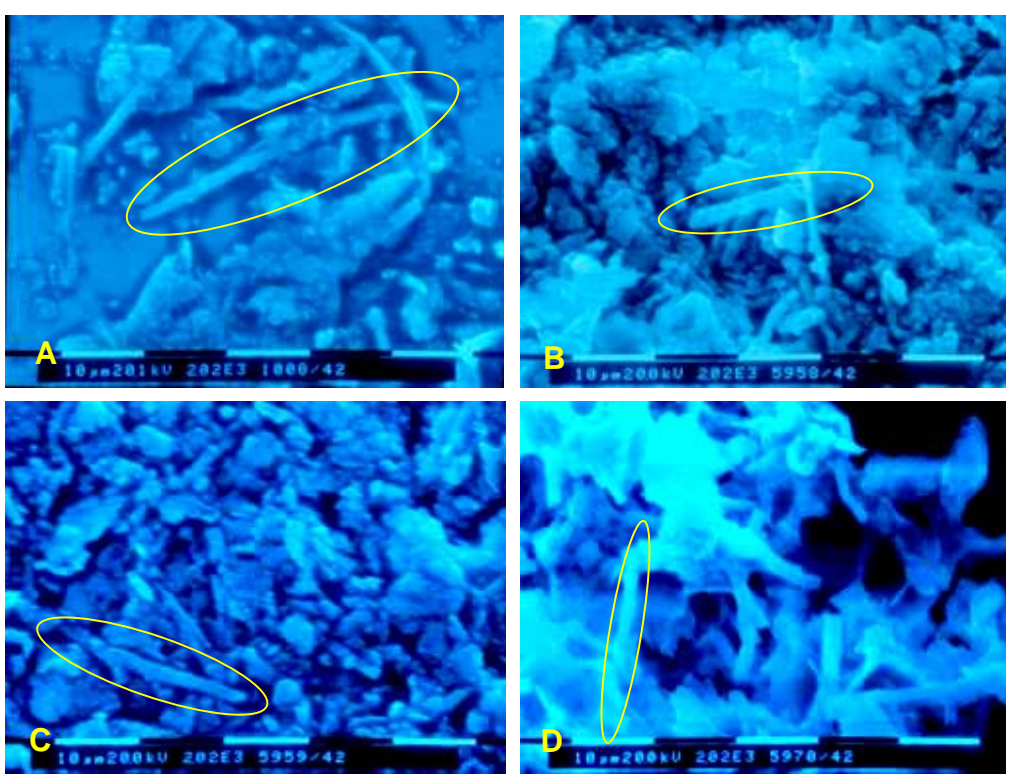

Grinding of samples in a stainless $25 \mathrm{ml}$ steel container was performed with a stainless steel ball (20 $\mathrm{mm}$ in diameter) in three repetitive cycles of 5 minutes each, interrupted for 10 minutes for cooling of mycelia in liquid nitrogen. No large fragments (more than $3.4 \pm 1.2 \mu \mathrm{m}$ in length), which could indicate the presence of intact hyphae, were observed by SEM in the flocks of aggregated cell material (see Fig. 5B, presenting a $2 \mathrm{X}$ magnification of Fig. 5A). Considerable improvement in grinding of mycelia was likely due to a better contact of the metal ball to the optimally rounded inner surface of the container and due to the higher volume space of the container.

Analysis by energy-dispersive X-ray microanalysis (EDAX) revealed only trace amounts of $\mathrm{Fe}$ and other metals indicating no sample contamination by abrasion from the stainless steel device. After transferring into the cell breaking buffer and 5 steps of purification including a 30\% sorbitol gradient (see materials and methods, Table 1), an aliquot of 10 mg purified powder was positively tested for laccase showing that the sample contained native enzymatic activities. Controlling enzymatic activities of the two intracellular 
cytosolic enzymes glucose-6-phosphatase dehydrogenase (G6PD), isocitrate dehydrogenase (IDH) and a mitochondrial enzyme marker malate dehydrogenase (MDH) showed that cytoplasmic contaminants were completely removed after the sorbitol gradient purification step (Table 1).
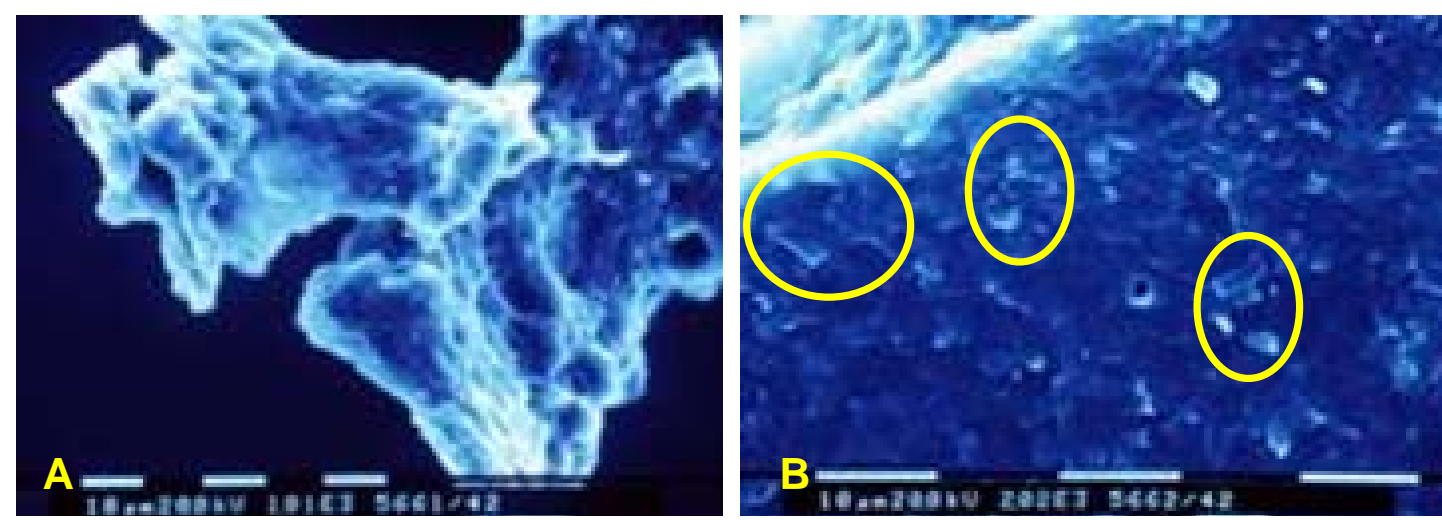

Fig. 5. SEM pictures of mycelia of $T$. versicolor after grinding with a stainless steel ball and stainless steel container of $25 \mathrm{ml}$ volume in a Mixer Mill from Retsch, Germany. Circles mark the short hyphal debris left in the sample (3.4 $\pm 1.2 \mu \mathrm{m}$ in length, calculated from 11 different hyphal fragments).

Table 1. Total protein amount and total activity of marker proteins during purification of the cell wall fraction (CWF). Values are given as total amounts per $\mathrm{mg}$ of dry weight per $100 \mathrm{mg}$ ground hyphal material (calculated from four replicates).

\begin{tabular}{lllll}
\hline Purification steps & $\begin{array}{l}\text { Protein / 100 } \\
\text { mg sample }[\mu \mathrm{g}]\end{array}$ & $\begin{array}{l}\text { G6PD } \\
{\left[\mathrm{U} \mathrm{mg}^{-1}\right]}\end{array}$ & $\begin{array}{l}\text { IDH } \\
{\left[\mathrm{mU} \mathrm{mg}^{-1}\right]}\end{array}$ & $\begin{array}{l}\text { MDH } \\
{\left[\mathrm{U} \mathrm{mg}^{-1}\right]}\end{array}$ \\
\hline $\begin{array}{l}\text { Washing with cell breaking } \\
\text { buffer 10 ml }\end{array}$ & $916.50 \pm 171.69$ & $0.0084 \pm 19.4$ & $0.0083 \pm 56.5$ & $0.0037 \pm 23.7$ \\
$\begin{array}{l}\text { Washing with cell breaking } \\
\text { buffer 10 ml }\end{array}$ & $318.9 \pm 5.84$ & $0.0010 \pm 5.2$ & $0.0036 \pm 2.4$ & $0.0031 \pm 9.9$ \\
$\begin{array}{l}30 \% \text { sorbitol gradient with 30 } \\
\text { ml }\end{array}$ & $59.36 \pm 22.83$ & $0.0040 \pm 1.4$ & 0.0 & $0.0029 \pm 8.5$ \\
$\begin{array}{l}\text { Washing with cell breaking } \\
\text { buffer 30 ml }\end{array}$ & $20.55 \pm 6.83$ & $0.0005 \pm 4.0$ & 0.0 & $0.0030 \pm 0.8$ \\
$\begin{array}{l}\text { Washing with distilled water } \\
\text { 30 ml }\end{array}$ & $14.27 \pm 1.79$ & $0.0001 \pm 1.1$ & 0.0 & $0.0006 \pm 0.3$ \\
Purified cell wall fraction & n.a. & $0.0 \pm 0.003$ & $0.0 \pm 0.002$ & $0.0 \pm 0.005$ \\
\hline
\end{tabular}

n.a. $=$ not analyzed

In total, approximately $100 \mathrm{mg}$ of purified cell wall sample was finally obtained from $200 \mathrm{mg}$ of freeze dried mycelium of T. versicolor. Similar yields were obtained in totally 
5 repeats of the experiments - freeze dried mycelium of $204.0 \pm 0.07 \mathrm{mg}$ resulted in $114.0 \pm 0.02 \mathrm{mg}$ of purified cell wall sample.

\subsubsection{The suitability of the purified CWF for proteomic analysis}

The very low contamination of the purified CWF of $T$. versicolor allows the use of these cell wall samples for proteomic studies of the cell wall associated proteins. In this study, we released non-covalently bound proteins by heating $10 \mathrm{mg}$ of sample in $1 \mathrm{ml}$ of protein extraction buffer from CWF containing 2.0\% SDS. After precipitation of the released proteins, $10 \mu \mathrm{g}$ of proteins (total yields of protein in 4 different experiments: $418 \pm 64 \mu \mathrm{g}$ ) were separated in 1D-SDS-PAGE. As seen in Fig. 6, the overall pattern of the noncovalently bound cell wall proteins differed considerably from those obtained from the fungal cytoplasm. The polypeptide profile from the cell wall extractions in five different independent experiments was comparable as tested by gel electrophoresis.

Fig. 6. SDS-PAGE of the cytoplasmic (lane $\mathrm{CT}$ ), cell wall (lane $\mathrm{CW}$ ), and supernatant proteins (lane SP) obtained from $T$. vesicolor mycelium after $10 \%$ TCA acetone precipitation. $10 \mu \mathrm{g}$ of total protein was loaded per sample. The gel was silver stained. Pure CW samples were prepared by using ball mill method $(25 \mathrm{ml}$ steel container with a $20 \mathrm{~mm}$ diameter stainless steel ball)

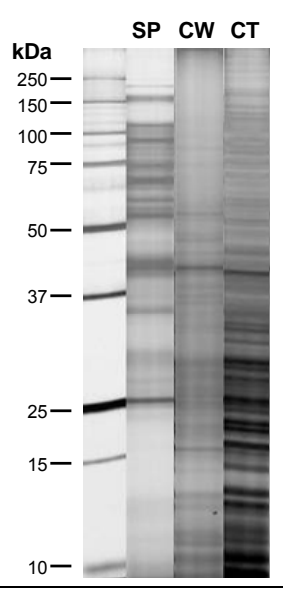

In 2D gel analysis, the non-covalent bond proteins from the CWF accumulated mostly in the near neutral pI range (pI $5.0-8.0$ ) at a molecular weight range of $10-100 \mathrm{kDa}$ (Fig. 7). A similar distribution in protein sizes is also seen with samples of noncovalently bound cell wall proteins of some ascomycetes (Trichoderma reesei, Candida albicans). However, the $\mathrm{pI}$ range in these species was shifted further into the acidic side up to a pI of 4.0 (Lim et al. 2001; Pitarch et al. 2002). 


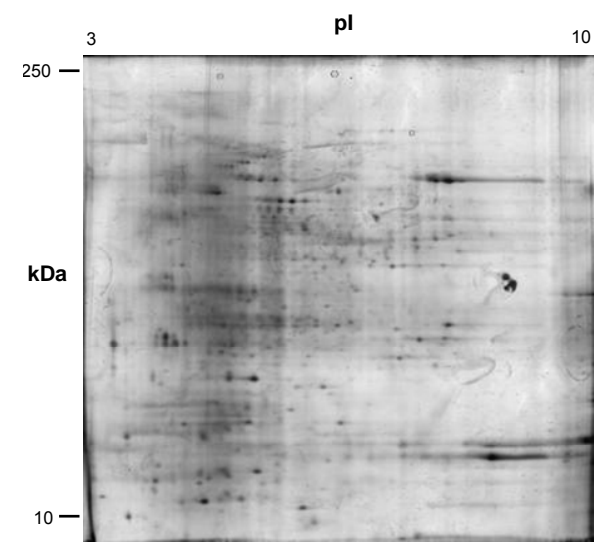

Fig. 7. 2D-map of non-covalently bound SDS extractable cell wall proteins of T. versicolor. $100 \mu \mathrm{g}$ of total protein were separated and the gel was silver stained. The molecular weight markers and $\mathrm{pI}$ range are indicated.

Fig. 8. 1D-SDS-PAGE of the cell wall (lane $\mathrm{CW}$ ) proteins obtained from $P$. ostreatus mycelium after 10\% TCA acetone precipitation. $10 \mu \mathrm{g}$ of total protein was loaded per sample (A), 2Dmap of non-covalently bound SDS extractable cell wall proteins of $P$. ostreatus. $100 \mu \mathrm{g}$ of total protein were separated. The molecular weight markers and $\mathrm{pI}$ range are indicated $(\mathbf{B})$. The gels were silver stained. Note that through a slimy contamination of likely carbohydrate nature interfering with iso-electric focusing, protein spots were poorly separated in subsequent 2Dgelectrophoresis.

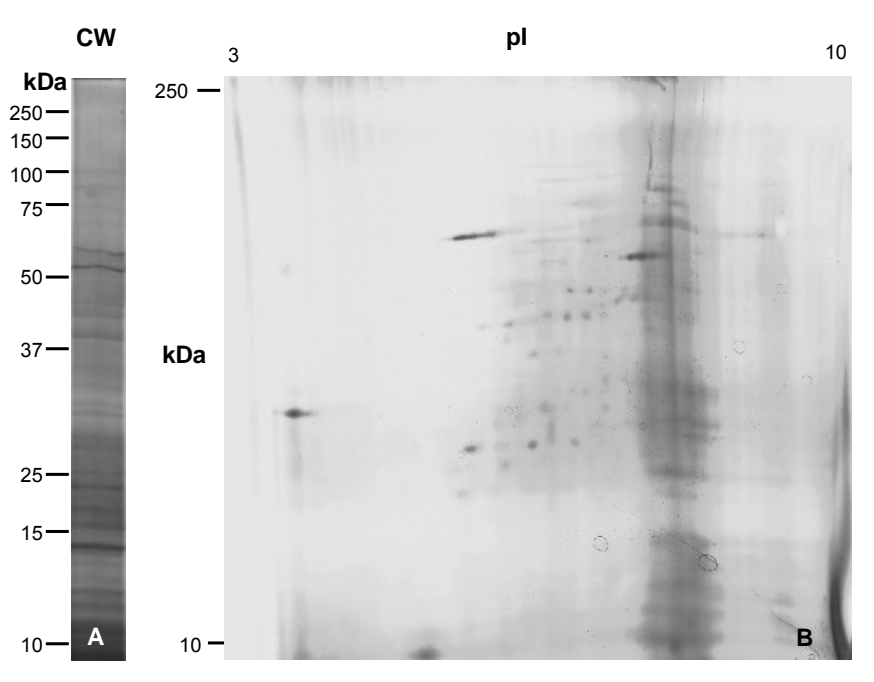

\subsubsection{Conclusion}

The work presented in this study show that ball mill grinding of freeze dried mycelia in a metal container with a large metal ball with subsequent purification steps was a very efficient and reproducible method to obtain pure CWF from higher basidiomycetes still containing native proteins.

Non-covalently bound proteins were easily isolated from the CWF. The same procedure was applied to the mycelium of $P$. ostreatus and - as much as the poor resolution in 2Dgelectrophoresis allows to conclude - a comparable pattern of non-covalent proteins to 
that of T. versicolor was obtained (Fig. $8 \mathrm{~A}$ and B). Hence, the method of cell wall breaking using a $25 \mathrm{ml}$ stainless steel jar with a $20 \mathrm{~mm}$ diameter stainless steel ball in a ball mill can be applicable also for mycelia of other basidiomycetes. Further developments will have to solve the problem of isolation of the covalently bound proteins from the CWF.

\subsection{References}

Angiolella L., Micocci M.M., D'Alessio S., Girolamo A., Maras B., and Cassone A. (2002). Identification of major glucan associated cell wall proteins of Candida albicans and their role in fluconazole resistance. Antimicrobial Agents and Chemotherapy 46:1688-1694.

Bernard M., and Latge J.P. (2001). Aspergillus fumigatus cell wall: composition and biosynthesis. Medical Mycology 39:9-17.

Bernard M., Mouyna I., Dubreucq G., Debeaupuis J.P., Fontaine T., Vorgias C., Fuglsang C., and Latge J.P. (2002). Characterization of a cell-wall acid phosphatase (PhoAp) in Aspergillus fumigatus. Microbiology-Sgm 148:2819-2829.

Blum H., Beier H., and Gross H.J. (1987). Improved silver staining of plant proteins, RNA and DNA in polyacrylamide gels. Electrophoresis 8:93-99.

Calonje M., Novaes-Ledieu M., Bernardo D., Ahrazem O., and Mendoza C.G. (2000). Chemical components and their locations in the Verticillium fungicola cell wall. Canadian Journal of Microbiology 46:101-109.

Cao L., Chan C.M., Lee C., Wong S.S.Y., and Yuen K.Y. (1998). MP1 encodes an abundant and highly antigenic cell wall mannoprotein in the pathogenic fungus Penicillium marneffei. Infection and Immunity 66:966-973.

Cramer C.L., Ristow J.L., Paulus T.J., and Davis R.H. (1983). Methods for mycelial breakage and isolation of mitochondria and vacuoles of Neurospora. Analytical Biochemistry 128:384392.

Damerval C., Devienne D., Zivy M., and Thiellement H. (1986). Technical Improvements in two dimensional electrophoresis increase the level of genetic variation detected in wheat seedling proteins. Electrophoresis 7:52-54.

Damveld R.A., Arentshorst M., VanKuyk P.A., Klis F.M., van den Hondel C.A.M.J., and Ram A.F.J. (2005). Characterisation of CwpA, a putative glycosylphosphatidylinositol-anchored cell wall mannoprotein in the filamentous fungus Aspergillus niger. Fungal Genetics and Biology 42:873-885. 
Gooday G.W. (1995). The growing fungus, In: Cell Wall. $1^{\text {st }}$ Edition (Gow N.A.R., Gadd G.M. eds.), Chapmann and Hall, London, pp. 43-62

Honda Y., Matsuyama T., Irie T., Watanabe T., and Kuwahara M. (2000). Carboxin resistance transformation of the homobasidiomycete fungus Pleurotus ostreatus. Current Genetics 37:209-212.

Hüttermann A., and Volger C. (1973). Induction of aryl beta glucosidase in Fomes annosus by cellobiose. Archiv fur Mikrobiologie 93:195-204.

Iranzo M., Aguado C., Pallotti C., Canizares J.V., and Mormeneo S. (2002). The use of trypsin to solubilize wall proteins from Candida albicans led to the identification of chitinase as an enzyme covalently linked to the yeast wall structure. Research in Microbiology 153:227-232.

Kang M.S., Elango N., Mattia E., Auyoung J., Robbins P.W., and Cabib E. (1984). Isolation of chitin synthetase from Saccharomyces cerevisiae purification of an enzyme by entrapment in the reaction product. Journal of Biological Chemistry 259:4966-4972.

Kapteyn J.C., Montijn R.C., Vink E., delaCruz J., Llobell A., Douwes J.E., Shimoi H., Lipke P.N., and Klis F.M. (1996). Retention of Saccharomyces cerevisiae cell wall proteins through a phosphodiester-linked beta-1,3-beta-1,6-glucan heteropolymer. Glycobiology 6:337-345.

Kapteyn J.C., Ram A.F.J., Groos E.M., Kollar R., Montijn R.C., Vandenende H., Llobell A., Cabib E., and Klis F.M. (1997). Altered extent of cross-linking of $\beta$-1,6-glucosylated mannoproteins to chitin in Saccharomyces cerevisiae mutants with reduced cell wall $\beta-1,3-$ glucan content. Journal of Bacteriology 179:6279-6284.

Kapteyn J.C., Van Den Ende H., and Klis F.M. (1999). The contribution of cell wall proteins to the organization of the yeast cell wall. Biochimica et Biophysica Acta-General Subjects 1426:373-383.

Laemmli U.K. (1970). Cleavage of structural proteins during assembly of head of bacteriophage T4. Nature 227:680-685.

Langdon R.G. (1966). Glucose 6-phosphate dehydrogenase from erythrocytes. Methods Enzymology, 9:126-131 9:126-131.

Latgé J.P. and Calderone R. (2006). The fungal cell wall. In: The Mycota, Growth, Differentiation and Sexuality, Vol. I, $\mathbf{2}^{\text {nd }}$ edition (Kües and Fischer eds.), Springer-Verlag, Heidelberg, in press.

Lim D.B., Hains P., Walsh B., Bergquist P., and Nevalainen H. (2001). Proteins associated with the cell envelope of Trichoderma reesei: A proteomic approach. Proteomics 1:899-909.

Matsumura E., Yamamoto E., Numata A., Kawano T., Shin T., and Murao S. (1986). Structures of the laccase catalyzed oxidation products of hydroxy benzoic acids in the presence of ABTS (2,2'-Azino-Di-(3-Ethylbenzothiazoline-6-Sulfonic Acid)). Agricultural and Biological Chemistry 50:1355-1357. 
Masuoka J., Guthrie L.N., and Hazen K.C. (2002). Complications in cell surface labelling by biotinylation of Candida albicans due to avidin conjugate binding to cell wall proteins. Microbiology-Sgm 148:1073-1079.

Peterson G.L. (1977). Simplification of protein assay method of lowry et al. which is more generally applicable. Analytical Biochemistry 83:346-356.

Pitarch A., Sanchez M., Nombela C., and Gil C. (2002). Sequential fractionation and twodimensional gel analysis unravels the complexity of the dimorphic fungus Candida albicans cell wall proteome. Molecular and cellular proteomics1.12: 967-982.

Roncal T., Ugalde U.O., Barnes J., and Pitt D. (1991). Production of protoplasts of Penicillium cyclopium with improved viability and functional properties. Journal of General Microbiology 137:1647-1651.

Ruiz-Herrera J. (1992). Chemical composition of the fungal cell wall. In: Fungal Cell Wall: Structure, Synthesis and Assembly (Ruiz-Herrera J. ed.), CRC Press, Boca Raton, pp. 5-22.

Sassoon J., and Mooibroek H. (2001). A system of categorizing enzyme-cell wall associations in Agaricus bisporus, using operational criteria. Applied Microbiology and Biotechnology 56:613-622.

Schoffelmeer E.A.M., Vossen J.H., van Doorn A.A., Cornelissen B.J.C., and Haring M.A. (2001). FEM1, a Fusarium oxysporum glycoprotein that is covalently linked to the cell wall matrix and is conserved in filamentous fungi. Molecular Genetics and Genomics 265:143152.

Sietsma J.H., and Wessels J.G.H. (2006). Apical wall biogenesis. In: The Mycota, Growth, Differentiation and Sexuality $\mathbf{2}^{\text {nd }}$ Edition (Kües U., Fischer R. eds.), Springer-Verlag, Berlin Heidelberg, pp. 261-290.

Specht C.A., Munozrivas A., Novotny C.P., and Ullrich R.C. (1991). Transformation of Schizophyllum commune - An analysis of specific properties. Experimental Mycology 15:326335 .

Taubert J., Krings U., and Berger R.G. (2000). A comparative study on the disintegration of filamentous fungi. Journal of Microbiological Methods 42:225-232. 
Detection of phenol oxidising enzymes from higher basidiomycetes by native staining in 1D and 2D-gel electrophoresis with various phenols and aromatic amine substrates 



\title{
3. Detection of phenol oxidising enzymes from higher basidiomycetes by native staining in $1 D$ and 2D-gel electrophoresis with various phenols and aromatic amine substrates
}

\begin{abstract}
3.1 Abstract
Substrate based in-gel staining is a very useful technique employed for detecting enzymes after electrophoretic separation. This work aimed at testing and comparing several phenols and aromatic amine substrates (DMP, TMA, pyrogallol etc.) for in-gel staining of laccases and other phenol oxidizing enzymes from basidiomycetes in 1D and 2D-electrophoresis followed by identification of corresponding enzymes by ESI-LC-MS. TMA/ $\alpha-n a p h$ thol and DHPPA/MBTH performed best within the screened substrates and allowed a high sensitivity of detection. The first staining was the most sensitive but the reaction product was water soluble and resulted in diffused bands (spots). Staining with DHPPA/MBTH was less sensitive but displayed very sharp bands that were stable upon storage of gels for several days.
\end{abstract}

\subsection{Introduction}

White rot fungi produce a wide range of extra-cellular enzymes, which help them to degrade lignin and cellulose (Leonowicz et al. 1999). Several of these enzymes react with phenols and aromatic amines as substrates. Laccases (1.10.3.2) for example accomplish the reduction of oxygen to water by the oxidation of aromatic substrates such as monophenols, ortho- and para-diphenols, polyphenols, methoxyphenols, ABTS [2,2'azino-bis(3-ethylbenzothiazoline-6-sulfonic acid)], ascorbic-, coumaric-, sinapic-, gallic-, ferullic-, coniferylic-, caffeic acid, aromatic diamines and lignin (Smith et al. 1997). Laccase belong to the multi-copper oxidase family that includes also catechol oxidase

Abbreviations: ABTS [2,2'-azino-bis(3-ethylenbenzothiazoline-6-sulfonic-acid)], DMP (2,6-dimethoxyphenol), DMAB [3-(dimethylamino)-benzoic acid], TMA (N,N,N’,N`-tetramethyl-1,4-phenylenediammonium dichloride), MBTH (3-methyl-2-benzothiazolinon-hydrazon-hydrochlorid monohydrat), DHPPA (3,4-dihydroxyhydrocinnamic acid), DAN (1,8-diaminonaphthalene). 
(1.10.3.1), ascorbate oxidase (1.10.3.3), monophenol monooxygenase (1.14.18.1) and ferroxidase (1.16.3.1). This enzyme, alternatively called urishiol oxidase, is classified by the Enzyme Commission as a member of oxidoreductases acting on polyphenols and related substances (1.10). Other member of this group commonly found in fungi is catechol oxidase (1.10.3.1) described also as diphenol oxidase, $o$-diphenolase, phenolase, polyphenol oxidase or tyrosinase. Catechol oxidase acts on monophenols and inserts a hydroxyl moiety at the ortho position with respect to the primary $\mathrm{OH}$ group. In the next step it may oxidise the resulting $o$-diphenol to the corresponding o-quinone. In contrast, oxidation of monophenols by laccase produces also $o$ - and $p$-quinones. Laccase and catechol oxidase that oxidize phenols using oxygen as an electron acceptor can alternatively be referred to as phenoloxidases (PO). Oxidation of substrates such as syringaldazine (4-hydroxy-3,5-dimethoxybenzaldhyde) (Harkin et al. 1973), ABTS (Majcherczyk et al. 1999), guaiacol (Eggert et al. 1996; Dong et al. 2004), and DMP (2,6-dimethoxyphenol) (Wariishi et al. 1992) is routinely used for detection of laccase activity, quantitatively by spectrophotometer tests as well as qualitatively for detection of enzymes in agar media.

Phenolic compounds can be also oxidized by peroxidases (1.11) and two such enzymes, lignin peroxidase and manganese peroxidase are commonly secreted by white rot fungi. They may act on the substrates directly or indirectly using a single Mn-ion (Wariishi et al. 1992) or veratryl alcohol (Khindaria et al. 1995) as mediator compounds and essentially require hydrogen peroxide as an electron acceptor. Therefore, they are easily distinguished in enzymatic reaction from other phenol oxidases.

Enzymes secreted by fungi comprise commonly a number of isoforms that differ in their activity towards the substrates. Enzymes and their isoforms can be separated using electrophoretic techniques such as 1D and 2D PAGE or isoelectric focusing. It is of high importance to visualize the enzymes after the separation using possibly specific methods. In-gel detection of PO on polyacrylamide gels is based on conversion of non-colored substrates into colored products. Compounds such as guaiacol (Dong et al. 2005), pyrogallol , DMP (2,6-dimethoxyphenol), ABTS (Xiao et al. 2003) and DAN (1,8diaminonaphthalene) (Hoopes et al. 2001) form chromogenic products upon enzymatic 
oxidation and thus allow localization of enzymes in gel after separation. By other methods, the primary substrate that is not oxidized to strongly colored products is coupled to another compound that enhances the color. For example, MBTH (3-methyl-2benzothiazolinon-hydrazon hydrochlorid) traps o-quinone products originating from the enzymatic oxidation of phenolic compounds such as DHPPA (3,4dihydroxyhydrocinnamic acid) and 4HA (4-hydroxyanisole) and forms a red color adduct (Dicko et al. 2002). Two enzyme substrates such as ADA (4-amino- $N-N$-diethylaniline) and tert-butyl-catechol can also be combined together for detection of phenol oxidizing enzymes. Intermolecular recombination of radical species formed in the primary oxidation stage and their further oxidation to quinones results in products of much higher color intensity (Rescigno et al. 1997). Other example of such reaction was presented by Sterjiades et al. (1993): TMA (N,N,N`,N`-tetramethyl-1,4-phenylenediammonium dichloride) along with $\alpha$-naphthol forms a blue color product after reacting with laccases. The above methods were tested for in-gel detection of laccases and polyphenol oxidases from fungi and plants. However, there is no comprehensive study that compares different substrates for detection of e.g. laccases and defines their relative sensitivities for in geldetection. In this study, we tested the known methods and also other combinations of enzyme substrates with laccases secreted by three different basidiomycetes, one saprophyte occurring in nature on dung (Coprinopsis cinerea) and wood degrading white rot fungi (Trametes versicolor) encountering in nature very likely different ranges of phenolic substrates.

\subsection{Materials and methods}

\section{Fungal cultures, induction of enzyme activities and harvesting of supernatants}

Trametes versicolor strain number 6 from the collection of the Institute of Forest Botany, Georg August Universität, Göttingen were cultivated on basidiomycetes-medium (BSM, Hüttermann and Volger, 1973) with 1.5\% agar. Starter liquid cultures were prepared by inoculation of $100 \mathrm{ml} \mathrm{BSM}$ liquid medium in $500 \mathrm{ml}$ conical flasks with three agar pieces $(1 \mathrm{~cm}$ in diameter $)$ of the stock culture and cultivated stationary at $25^{\circ} \mathrm{C}$ in the 
dark. Mycelium of 14 days-old liquid cultures were gently disrupted using an UltraTurrax T25 (rod diameter $10 \mathrm{~mm}$; Janke \& Kunkel, IKA-Labortechnik, Germany) at 9,000 rpm for 1 minute under sterile conditions. Each $4 \mathrm{ml}$ of mycelium suspension were used to inoculate new $100 \mathrm{ml}$ BSM liquid cultures. Standing cultures of T. versicolor were induced after seven days with $100 \mu 10.5 \mathrm{M}$ 2,5-xylidine and $100 \mu 1150 \mathrm{mM}$ $\mathrm{CuSO}_{4}$ respectively of incubation and incubated further for seven more days stationary at $25^{\circ} \mathrm{C}$ in the dark. The culture supernatants were harvested by vacuum filtration using filter paper (595 Round filter, Ø 90 mm, Schleicher \& Micro Science GmbH, Germany). Coprinopsis cinerea AmutBmut was grown in YMG/T media (Granado et al. 1997) supplemented with $0.2 \mathrm{mM}$ copper and cultures kindly provided by M. NavarroGonzález. Starter liquid cultures were prepared by inoculation of $100 \mathrm{ml} \mathrm{YMG/T} \mathrm{liquid}$ medium in $500 \mathrm{ml}$ conical flasks with three agar pieces $(1 \mathrm{~cm}$ in diameter) of a stock culture and cultivated stationary at $37^{\circ} \mathrm{C}$ in the dark. Mycelium of five days-old liquid cultures were gently disrupted using an Ultra-Turrax T25 at 9,000 rpm for 1 minute under sterile conditions. Each $1 \mathrm{ml}$ of mycelium suspension were used to inoculate new $100 \mathrm{ml} \mathrm{YMG} / \mathrm{T}$ liquid cultures. Standing cultures were grown at $37^{\circ} \mathrm{C}$ for 3 days and supernatants were harvested as above.

\section{Native protein sample preparation}

The supernatant obtained from 14 days old cultures was centrifuged for $20 \mathrm{~min}$ at 3,000 g and was concentrated by ultra-filtration with 3,000 MWCO membrane (Vivaspin, Vivascience AG, Hannover Germany) at 3,000 g to obtain at least $20 \mathrm{U} / \mathrm{ml}$ concentration of laccase activity. Laccase activity was measured by oxidation of ABTS in spectrophotometeric test at $420 \mathrm{~nm}$ for 5 minutes as described by Matsumura et al. (1986).

\section{Native 1D/2D-PAGE and in-gel staining of native phenoloxidases}

1D-PAGE electrophoresis was performed using $12 \times 12 \mathrm{~cm}$ discontinuous $12 \%$ acrylamide gels with $0.025 \mathrm{M}$ Tris base, $\mathrm{pH} 8.3$ as electrode buffer (Laemmli 1970). Protein samples were mixed in sample buffer $(0.06 \mathrm{M}$ Tris-Cl, $\mathrm{pH} 6.8,10 \%$ glycerol, 
$0.025 \%$ bromphenol blue). $20 \mu \mathrm{l}$ samples corresponding to $6-10 \mathrm{mU}$ laccase activity were loaded and run at $10-15^{\circ} \mathrm{C}$ at a constant current of $30 \mathrm{~mA}$.

For 2D-electrophoresis, protein samples were dissolved in loading buffer [ $8 \mathrm{M}$ urea, 4\% (w/v) CHAPS, $50 \mathrm{mM}$ DTT, 5\% (v/v) Triton X100, 0.67\% (v/v), ampholyte buffer (Amersham Biosciences)]. $350 \mu 1$ of sample solution containing approximately 80-100 $\mu \mathrm{g}$ protein was loaded on $18 \mathrm{~cm}$ IPG-strips, $\mathrm{pH}$ range 3-10 (Amersham Biosciences) in ceramic holders, rehydrated and focused using an Ettan IPGphor isoelectric focusing machine (Amersham) for a total of $46,000 \mathrm{Vhr}$ at $15^{\circ} \mathrm{C}$ with the following settings: 100 $\mu \mathrm{A}$ per strip, (12 hr, $20 \mathrm{~V}$, step and hold), $200 \mathrm{~V}$ (1hr), $500 \mathrm{~V}$ (1hr), 1,000 Vhr, 8,000 $\operatorname{Vhr}(8,000 \mathrm{~V}), 40000 \mathrm{Vhr}(8,000 \mathrm{~V})$, all according to the protocol of the manufacture. In the $2^{\text {nd }}$ dimension, proteins were separated on $12 \%$ PAGE using Ettan DALTsix electrophoresis chamber (Amersham) together with a protein marker (Precision Protein Marker, Biorad, 10-250 kDa).

Proteins were separated at $10^{\circ} \mathrm{C}$ for $5.5 \mathrm{hrs}$ in two steps: Step-1: $600 \mathrm{~V}, 400 \mathrm{~mA}$ for 30 min (low voltage is applied for short time to allow the migration of proteins from the IPG strip on to the gel), step-2: $3000 \mathrm{~V}, 400 \mathrm{~mA}, 100 \mathrm{~W}$ for $5 \mathrm{hrs}$ (high voltage is applied for longer time to resolve the protein spots). The gels were fixed in $30 \%$ methanol with $12 \%$ acetic acid and $0.05 \%$ formaldehyde overnight and subsequently stained with silver (Blum et al. 1987). For colloidal Coomassie blue staining, gels were fixed in $12 \%(\mathrm{w} / \mathrm{v})$ trichloroacetic acid (TCA) solution overnight (Candiano et al. 2004). For native staining, gels were transferred to $100 \mathrm{mM}$ sodium acetate buffer $\mathrm{pH} 5.0$ for $30 \mathrm{~min}$. The buffer was changed by $100 \mathrm{ml}$ of fresh buffer and substrates of interest and combinations of substrate were added and incubated with the gels at room temperature according to need (Table 1). Stained gels were scanned at 300 dpi resolution (Microtek, TMA 1600, Hannover, Germany).

\section{Protein identification by ESI-LC-MS analysis}

Stained bands were excised from 1D gels, cut into small pieces, washed once with $200 \mu 1$ of distilled water for 15 minutes and $200 \mu \mathrm{l}$ of $50 \%$ methanol, and dehydrated in $200 \mu \mathrm{l}$ of pure acetonitrile for $20 \mathrm{~min}$. In-gel digestion of proteins with trypsin was performed at 
$58^{\circ} \mathrm{C}$ as described by Havlis et al. (2003). The resulting peptides were extracted in two steps with $200 \mu \mathrm{l}$ of $5 \%$ formic acid and $200 \mu 1$ of $50 \%$ acetonitrile with $5 \%$ formic acid (30 min each step). The pooled extracts were concentrated using vacuum concentrator and peptides were dissolved in $5 \mu 1$ of $5 \%$ formic acid for ESI-LC-MS. $4 \mu 1$ of sample was analyzed by ESI-LC-MS (Esquire-3000, Bruker Daltonics, Bremen, Germany). Gel eluted peptides were injected into the liquid chromatography columns and the corresponding peptides were passed through a high-voltage electric path for ionization in the mass spectrometer, ESI-LC-MS (Electro Spray Ionization-Liquid ChromatographMass Spectrometer; Esquire-3000, Bruker Daltonics, Bremen, Germany) for mass spectrometric analysis. MS/MS spectra obtained from the ESI-MS detector were further processed by the Bruker Daltonics Data Analysis software (Interactive data processing, esquire series) and exported to the protein database and search engine Mascot (version 2.0, Matrix Science, http://www.matrixscience.com/search_form_select.html) in Mascot Generic Format (MGF). Searches were performed first against a commercial mass spectrometry data base (MSDB) (ftp://ftp.ncbi. nih.gov/repository/MSDB/msdb.nam). In addition, an own database for Mascot analysis was created (19 ${ }^{\text {th }}$ May 2005) with sequences from SNAP predictions and annotated protein sequences from the $C$. cinerea genome (Jason Stajich, Duke University, unpublished, http://genome.semo.edu/cgibin/gbrowse/coprinus) combined with the SwissProt database, the NCBI database, the annotated Phanerochaete chrysosporium proteins, and 17 laccase sequences from $C$. cinerea annotated by S. Kilaru (unpublished). All cysteine residues were searched as reduced and methionine residues in the oxidized form. Mascot parameters were set to use monoisotopic masses with tolerance of 1.5 for precursor ions and 0.5 for fragment ions.

\subsection{Result and discussion}

\subsubsection{In-gel detection of phenol oxidizing enzymes by various substrates}

Supernatant proteins of cultures from the two basidiomycetes $C$. cinerea and $T$. versicolor induced by copper, respectively xylidine for PO production were separated by native 1D-PAGE and PO activities visualized by incubating gel segments with different 
substrates and combinations of substrates with coreactants. POs reacted differently with substrates and combinations of substrates with coreactants (Fig. 1-4).

C. cinerea showed the highest number of PO sensitive bands (Fig. 1), at the maximum six when stained with the combination of the two substrates TMA and $\alpha$-naphthol. The combination of TMA with the coreactant MBTH was second best in sensitivity with staining of five different bands. Also the combination of DAN with MBTH gave five bands, but these were only poorly stained. Of the single substrates, TMA and ADA gave four bands, with TMA staining being stronger. All other substrates and substratecoreactant combination were less sensitive by showing less numbers of bands and/or very faint staining. Substrates that gave very faint bands in $30 \mathrm{~min}$ in-gel staining of POs were $\alpha$-naphthol, ABTS, DMP, DAN, guaiacol and pyrogallol and the coreactant DHPPA in

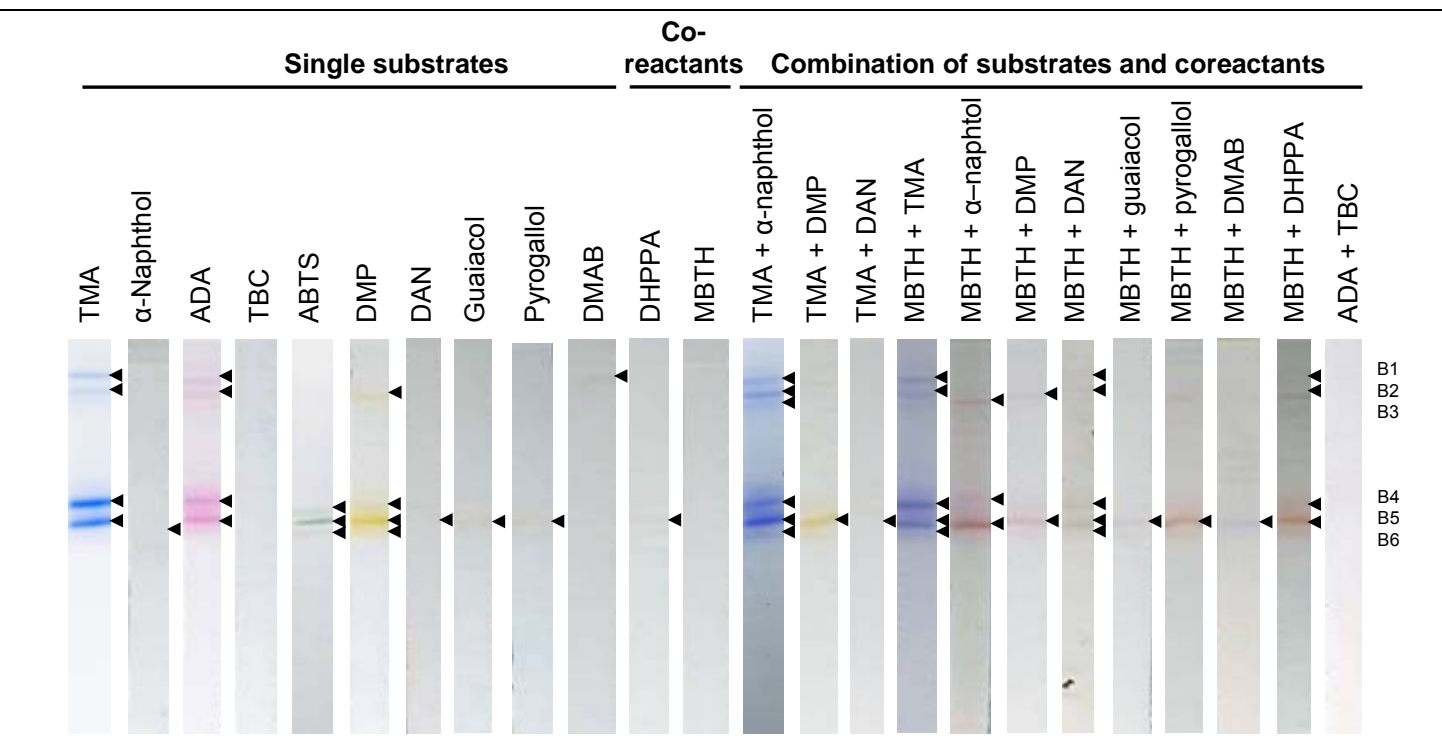

Fig. 1. In-gel staining of $C$. cinerea supernatant proteins from a 3 day-old copper-induced $100 \mathrm{ml} \mathrm{YMG} / \mathrm{T}$ standing culture grown at $37^{\circ} \mathrm{C}$. Laccase activity within the supernatant at this time point was $20.3 \mathrm{mU} / \mathrm{ml}$. Proteins from the supernatant were 30 times concentrated and each $10.7 \mu 1$ (corresponding to $10 \mathrm{mU}$ enzyme activity) were loaded on a $12 \%$ polyacrylamide gel that were run at $30 \mathrm{~mA}$ in electrode buffer afterwards. The gel was cut into lanes that individually were incubated with either a substrate, a coreactant or a combination of a substrate and a coreactant (see material and methods) as indicated in the figure above the stained lanes. Gel slices were continuously observed during staining but all photography was done 30 min after start of incubation, with the consequence that not all lanes showed the optimal point of staining. Arrows at the right side to the lanes indicate positions of enzyme bands that reacted with the respective compound(s). Note that shrinking difference of gel slices occurred between different treatments by the different chemicals used. Number B1 to B6 refer to individual phenoloxidase activities. 
single reaction, while the substrates $\mathrm{TBC}$ and $\mathrm{DMAB}$ and the coreactant $\mathrm{MBTH}$ in single reaction did not give any colored band (Fig. 1). In substrate-coreactant and substrate-substrate combinations, MBTH + DHPPA gave 4 bands, MBTH $+\alpha$-naphthol gave three colored bands, MBTH + DMP two colored bands and TMA + DMP, TMA + DAN, MBTH + guaiacol, MBTH + pyrogallol, MBTH + DMAB each one colored band, and $\mathrm{ADA}+\mathrm{TBC}$ no band. In summary, these data were combined with data of other experiments in Table 1.

Several of the substrate-coreactant combinations tested were less effective in staining than the single components: TMA + DMP, TMA + DAN versus TMA and DMP, MBTH + DMP versus DMP. Equal results to single substrate were obtained with combination of $\mathrm{MBTH}+$ guaiacol and MBTH, and MBTH + pyrogallol and pyrogallol. More bands compared to single substrate were seen with the combination of TMA $+\alpha$-naphthol and MBTH + TMA (Fig. 1).

Of further disadvantage for routine application of certain stainings, the color products formed in gel after reaction of POs with substrates ABTS, DMP, guaiacol and pyrogallol diffused away from the gel already after 10-15 min of gel staining (observations not documented by photographs). Therefore, the stained slices shown in Fig. 1 were normally photographed at suboptimal incubation time where bands already partially disappeared. TMA and ADA in contrast still resulted in sharp bands (Fig. 1) which however also started to diffuse after 10-15 min of gel staining. Also TMA $+\alpha$-naphthol staining was little stable - fading of the colour was observed already after 10 to 15 min of incubation (observations not shown). MBTH + TMA staining started after about 20 min of incubation to diffuse (observations not shown). In contrast, MBTH + DAN and MBTH + DHPPA staining intensified over the time. Bands in MBTH + DAN were still stable after 3 hours of incubation and bands in MBTH + DHPPA after 2 days of storage at room temperature (observations not shown). In conclusion, for most sensitive staining, TMA $+\alpha$-naphthol should be taken although it is less stable than some of the other substrate-coreactant combinations. 
In a repeat of parts of the staining (with partially different times of staining) with supernatant from another C. cinerea culture induced for PO production with copper, similar results on sensitivity of substrates and coreactants were obtained (Fig. 2). There were however only maximum 5 bands with the best stain (TMA $+\alpha$-naphthol, MBTH + TMA). These differences in the two experiments were likely due to the different cultures used than due to the alteration in the staining times, since gels were continuously observed during the staining.

Table 1. Detection of phenoloxidase activity within gels with C. cinerea proteins.

\begin{tabular}{|c|c|c|c|c|}
\hline $\begin{array}{c}\text { Substrates, coreactants and } \\
\text { their combinations }\end{array}$ & $\begin{array}{l}\text { Optimal time } \\
\text { of staining } \\
\end{array}$ & $\begin{array}{c}\text { No. of visible } \\
\text { bands }\end{array}$ & $\begin{array}{c}\text { Sensitivity } \\
1-5^{\mathrm{c}} \\
\end{array}$ & Reference $^{d}$ \\
\hline \multicolumn{5}{|l|}{ Single substrates } \\
\hline TMA $8.9 \mathrm{mM}$ & $10 \min (15 \mathrm{~min})$ & 4 & $4-5$ & This study \\
\hline$\alpha$-Naphthol $9.7 \mathrm{mM}$ & $30 \mathrm{~min}$ & 1 & 1 & This study \\
\hline ADA $25 \mathrm{mM}$ & $10 \min (15 \min )$ & 4 & $4-5$ & Rescingo et al. 1997 \\
\hline TBC $25 \mathrm{mM}$ & - & 0 & 0 & Rescingo et al. 1997 \\
\hline ABTS $50 \mathrm{mM}$ & $30 \min (60 \mathrm{~min})$ & 3 & $1-2$ & Xiao et al. 2003 \\
\hline DMP $20 \mathrm{mM}$ & $30 \mathrm{~min}$ & 4 & $1-2$ & This study \\
\hline DAN $50 \mathrm{mM}$ & $70 \mathrm{~min}$ & 1 & 1 & Hoopes et al. 2001 \\
\hline Guaiacol $50 \mathrm{mM}$ & $60 \mathrm{~min}$ & 1 & 1 & Eggert et al. 1996 \\
\hline Pyrogallol $50 \mathrm{mM}$ & $60 \mathrm{~min}$ & 1 & 1 & Wariishi et al. 1992 \\
\hline DMAB $20 \mathrm{mM}$ & $30 \mathrm{~min}$ & 1 & 1 & This study \\
\hline \multicolumn{5}{|l|}{ Coreactants } \\
\hline DHPPA $10 \mathrm{mM}$ & $30 \mathrm{~min}$ & 1 & 1 & This study \\
\hline MBTH $10 \mathrm{mM}$ & - & 0 & 0 & This study \\
\hline \multicolumn{5}{|c|}{ Substrate combinations with coreactants } \\
\hline TMA $8.4 \mathrm{mM}+\alpha$-naphthol $9.7 \mathrm{mM}$ & $10 \min (15 \min )$ & 6 & 5 & Sterjiades et al. 1993 \\
\hline TMA $8.4 \mathrm{mM}$ + DMP $20 \mathrm{mM}$ & $30 \mathrm{~min}$ & 1 & $1-2$ & This study \\
\hline TMA $8.4 \mathrm{mM}+$ DAN $50 \mathrm{mM}$ & $30 \mathrm{~min}$ & 1 & $1-2$ & This study \\
\hline MBTH $10 \mathrm{mM}+$ TMA $8.4 \mathrm{mM}$ & $20 \mathrm{~min}$ & 5 & 5 & This study \\
\hline MBTH $10 \mathrm{mM}+\alpha$-naphthol $9.7 \mathrm{mM}$ & $30 \mathrm{~min}$ & 3 & $1-2$ & This study \\
\hline MBTH $10 \mathrm{mM}$ + DMP $20 \mathrm{mM}$ & $30 \mathrm{~min}$ & 2 & $1-2$ & This study \\
\hline MBTH $10 \mathrm{mM}$ + DAN $50 \mathrm{mM}$ & $70 \mathrm{~min}$ & 5 & $2-3$ & This study \\
\hline MBTH $10 \mathrm{mM}$ + guaiacol $20 \mathrm{mM}$ & $60 \mathrm{~min}$ & 1 & $1-2$ & This study \\
\hline MBTH $10 \mathrm{mM}+$ pyrogallol $50 \mathrm{mM}$ & $60 \mathrm{~min}$ & 1 & $1-2$ & This study \\
\hline MBTH $10 \mathrm{mM}$ + DMAB $20 \mathrm{mM}$ & $30 \mathrm{~min}$ & 1 & 1 & This study \\
\hline MBTH $10 \mathrm{mM}$ + DHPPA $10 \mathrm{mM}$ & $60 \min (70 \min )$ & 4 & $3-4$ & Dicko et al. 2002 \\
\hline $\mathrm{ADA}+4$-tert-butyl-catechol & - & 0 & 0 & Rescingo et al. 1997 \\
\hline
\end{tabular}




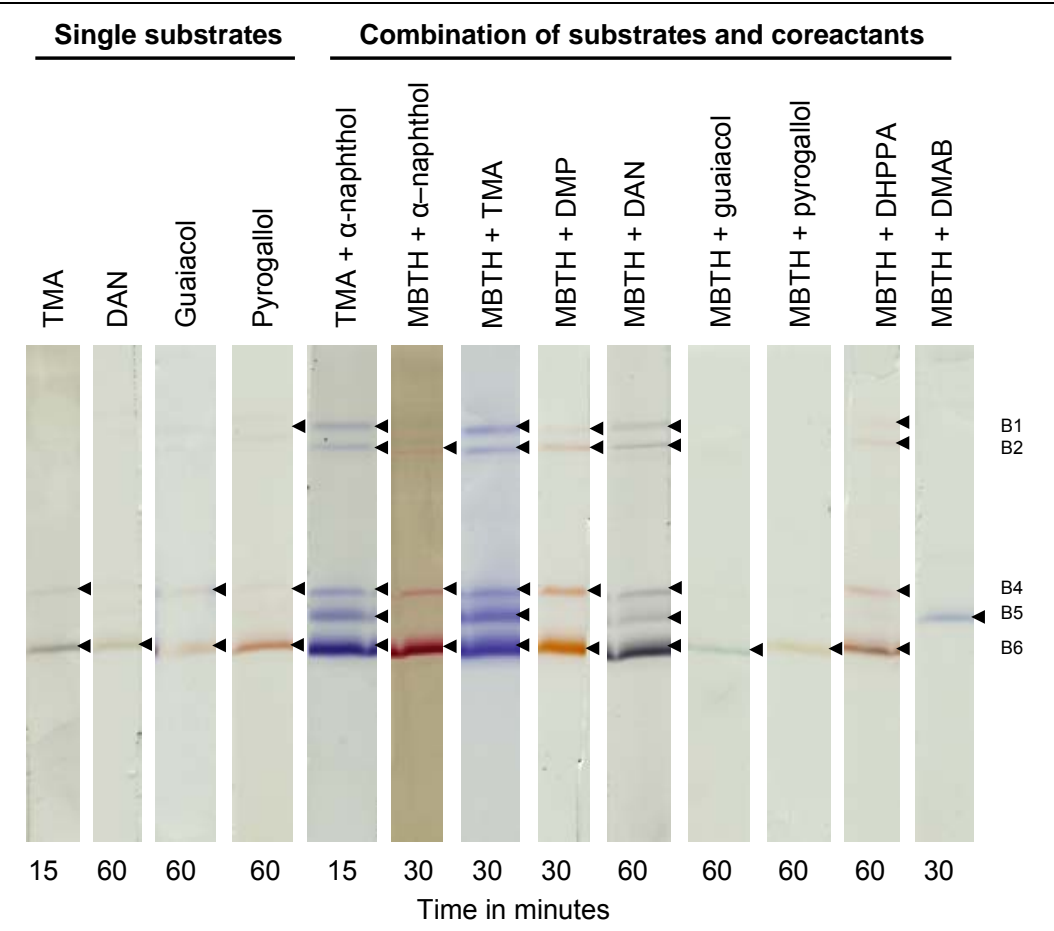

Fig. 2. In-gel staining of $C$. cinerea supernatant proteins from a 3 day-old copper-induced $100 \mathrm{ml}$ YMG/T standing culture grown at $37^{\circ} \mathrm{C}$. Laccase activity within the supernatant at this time point was $36.5 \mathrm{mU} / \mathrm{ml}$. Proteins from the supernatant were 28.5 times concentrated and each $9.73 \mu 1$ (corresponding to $10 \mathrm{mU}$ enzyme activities) were loaded on $12 \%$ polyacrylamide gel that were run at 30 $\mathrm{mA}$ in electrode buffer afterwards. The gel was cut into lanes that individually were incubated with either a substrate or a combination of a substrate and a coreactant (see material and methods) as indicated in the figure above the stained lanes. Gel slices were continuously observed during staining. All photography was done at a staining time believed to be optimum. Arrows at the right side to the lanes indicate positions of enzyme bands that reacted with the respective compounds. Note that shrinking difference of gel slices occurred between different treatments by the different chemicals used. Number $\mathrm{B} 1$ to $\mathrm{B} 6$ refer to individual phenoloxidase activities.

To better document optimal staining times, selected substrates and combination of substrates were further analyzed with C. cinerea protein samples (Fig. 3). In TMA staining and TMA $+\alpha$-naphthol, after 10 minutes optimum staining were achieved. After this time fading started for both treatments, but fading with TMA $+\alpha$-naphthol was more quickly. In case of MBTH + TMA staining, 20 min incubation were optimal for best detection of PO's, whilst longer incubation caused fading of bands. MBTH + DAN staining needed $70 \mathrm{~min}$ for best results. Parallel samples treated for 70 min only with DAN or MBTH reacted were little respectively not in staining protein bands. 
Concluding from all C. cinerea experiments, optimal times for staining have been deduced and compiled in Table 1.

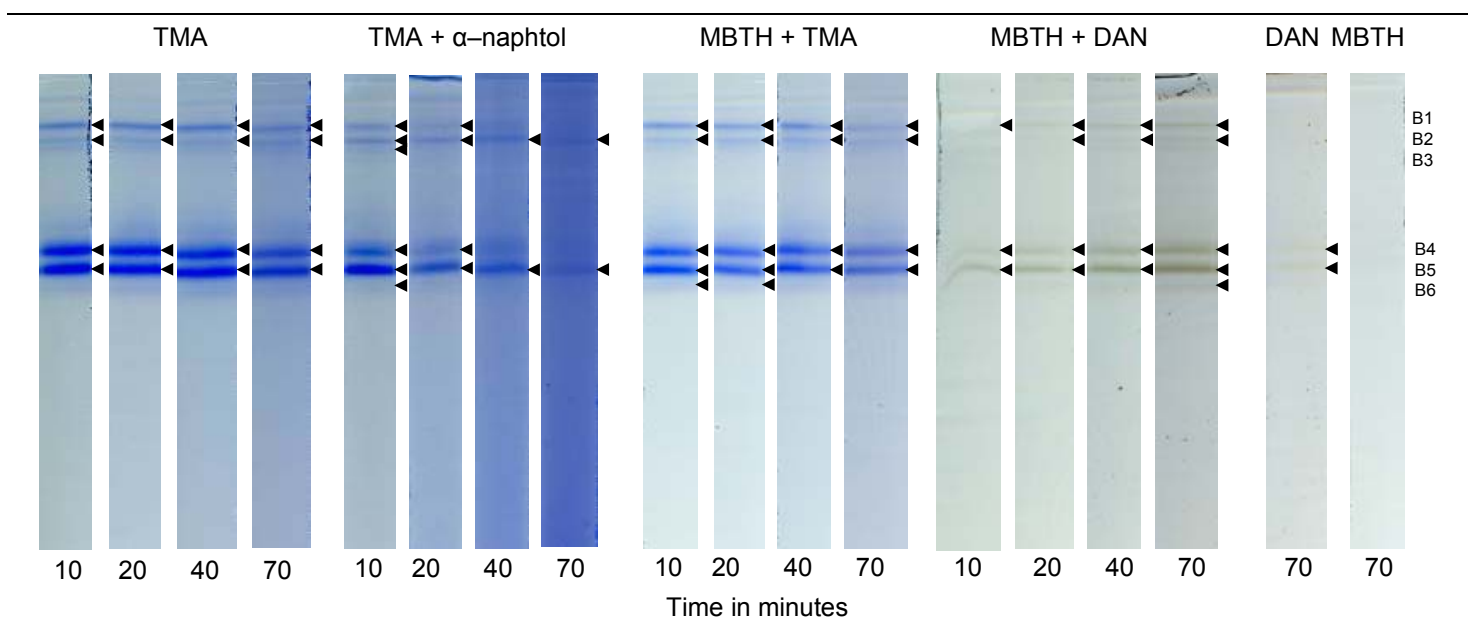

Fig. 3. In-gel staining of $C$. cinerea supernatant proteins from the same culture as in the Fig. 1. 10. $7 \mu 1$ of concentrated protein was loaded on a $12 \%$ polyacrylamide gel corresponding to $10 \mathrm{mU}$ of enzyme activity and were run at $30 \mathrm{~mA}$ in electrode buffer afterwards. The gel was cut into lanes that individually were incubated with mentioned substrate, a coreactant or a combination of a substrate and a coreactant (see material and methods) as indicated in the figure above the stained lanes. Gel slices were continuously observed during staining and photographs were taken at mentioned time points. Arrows at the right side to the lanes indicate positions of enzyme bands that reacted with the respective compounds.

For xylidine-induced cultures of T. versicolor, the same set of experiments as shown in Fig. 1 for C. cinerea was performed for PO staining. ABTS, TMA $+\alpha$-naphthol, MBTH $+\alpha$-naphthol and ADA + TBC each detected two PO activity bands while only one PO sensitive band was seen in all other stainings (Fig. 4). Amongst the single substrates, ABTS gave the strongest band, followed by TMA. ADA and DMP gave bands of medium strength and $\alpha$-naphthol, DAN, guaiacol, pyrogallol only faint bands whilest TBC and DMAB did not react at all. Coreactant DHPPA gave a faint band and no reaction was seen in the case of MBTH. In combinations of substrates and coreactants, TMA $+\alpha$-naphthol, TMA + DMP and MBTH $+\alpha$-naphthol resulted in strong bands whereas substrates and coreactants TMA + DAN, MBTH + TMA, MBTH + pyrogallol, $\mathrm{MBTH}+\mathrm{DMAB}, \mathrm{MBTH}+\mathrm{DHPPA}$ combinations resulted in bands of medium strength. $\mathrm{MBTH}+\mathrm{DMP}, \mathrm{MBTH}+\mathrm{DAN}, \mathrm{MBTH}+$ guaiacol and ADA + TBC gave faint bands 


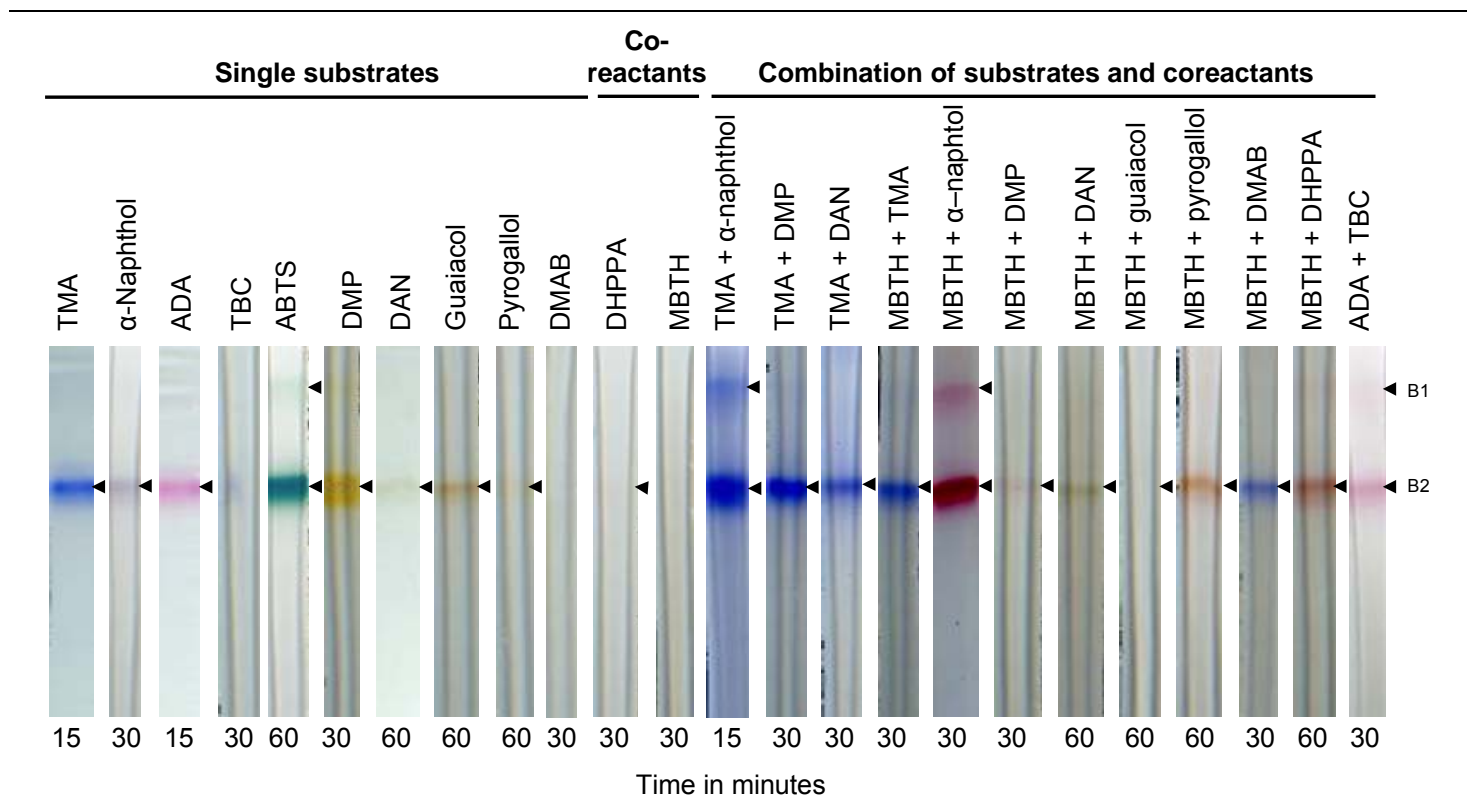

Fig. 4. In-gel staining of T. versicolor supernatant proteins from a 14 day-old xylidine-induced $100 \mathrm{ml}$ $\mathrm{BSM}$ standing culture grown at $25^{\circ} \mathrm{C}$. Laccase activity within the supernatant at this time point was 1590 $\mathrm{mU} / \mathrm{ml}$. Proteins from the supernatant were 14.4 times concentrated and each $0.4 \mu 1$ (corresponding to 10 $\mathrm{mU}$ of enzyme activities) were loaded on a $12 \%$ polyacrylamide gel that were run at $30 \mathrm{~mA}$ in electrode buffer. The gel was cut into lanes that individually were incubated with either a substrate or a combination of a substrate and a coreactant (see material and methods) as indicated in the figure above the stained lanes. Gel slices were continuously observed during staining. Arrows at the right side to the lanes indicate positions of enzyme bands that reacted with the respective compounds. Note that shrinking difference of gel slices occurred between different treatments by the different chemicals used.

In conclusion, during staining of the white-rot $T$. versicolor proteins, TMA $+\alpha$-naphthol showed highest sensitivity towards POs followed by MBTH + DHPPA. However, unlike in the saprophyte $C$. cinerea, ABTS staining showed a strong reaction for POs in $T$. versicolor. C. Lang (2004) conducted a parallel series of experiments with proteins from culture supernatants of white-rot Heterobasidion annosum. For proteins of this fungus, TMA $+\alpha$-naphthol, MBTH + pyrogallol, MBTH + DHPPA and ABTS were equally good.

To test the sensitivity of PO staining in gel further, purified laccase (Lcc-III) from a xylidine-induced T. versicolor culture (see chapter 4) were analyzed with two of the combinations, TMA $+\alpha$-naphthol and MBTH + DHPPA. TMA $+\alpha$-naphthol could detect as low as $0.112 \mathrm{mU}$ of enzyme activity. This was 11 times more sensitive than 
MBTH + DHPPA staining that could detect a minimum of $1.25 \mathrm{mU}$ of laccase activity (Fig. 5).

Fig. 5. In-gel staining of purified $T$. versicolor supernatant laccase (Lcc-III) from a 14 day-old 2.5 xylidine-induced $100 \mathrm{ml} \mathrm{BSM} \mathrm{standing} \mathrm{culture} \mathrm{grown}$ at $25^{\circ} \mathrm{C}$. Serial dilutions of concentrated laccase activity (40 to $0.112 \mathrm{mU}$ ) were loaded on a $12 \%$ polyacrylamide gel and run at $30 \mathrm{~mA}$ in electrode buffer Lane 1-9 contain $40 \mathrm{mU}, 20 \mathrm{mU}, 10 \mathrm{mU}, 5$ $\mathrm{mU}, 2.5 \mathrm{mU}, 1.25 \mathrm{mU}, 0.625 \mathrm{mU}, 0.322 \mathrm{mU}$ and $0.112 \mathrm{mU}$ of laccase activity, respectively. (A) Staining with $9.7 \mathrm{mM}$ a-naphthol, $8.9 \mathrm{mM}$ N,N,N',N'-tetramethyl-p-phenylene diamine for 15 minutes. (B) Staining with $10 \mathrm{mM}$ MBTH, $10 \mathrm{mM}$ DHPPA for $30 \mathrm{~min}$.

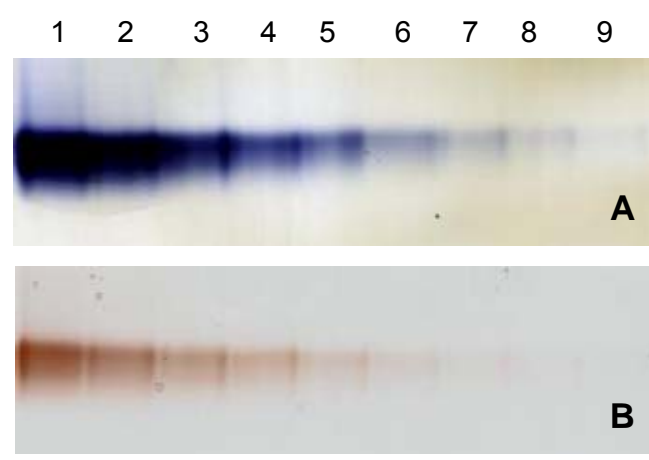

\subsubsection{Identification of PO by ESI- LC-MS}

Several phenoloxidases were detected in the supernatants of copper and xylidine-induced cultures from the two basidiomycetes C. cinerea and T. versicolor, respectively (e.g. see Fig. 1 and Fig. 4). In such mixtures of similar proteins, it is difficult to identify all the individual proteins. Therefore, proteins need to be separated from each other. Chromatography on suitable ion-exchange, size exclusion and affinity columns can possibly separate some or even all of PO's from each other. However, for such protein purification, sufficient amount of proteins are needed. In consequence, proteins present in only very low amounts likely will be overlooked. Furthermore, it is possible that in chromatography proteins with alike properties will not be separated from each other (see as an example the C. cinerea laccase Lcc1 isoforms, Kilaru 2006).

When proteins are separated by gel electrophoresis and activity stained with high sensitivity by a suitable substrate for PO detection or with a suitable substrate-coreactant combination (see 3.4.1) also PO's present in minor amounts will be detected. Loading higher amounts of proteins on a 1D-gel can demonstrate this (Fig. 6A). With increasing protein amounts from supernatant of a copper induced culture of C. cinerea homokaryon AmutBmut, additional faint PO bands appear.

To test whether behind strong bands in 1D-gel-electrophoresis hide more than one protein, samples were separated on 2D-gels (Fig. 6B). In samples from homokaryon AmutBmut of C. cinerea, seven different PO's were seen in 2D-gel. Most interestingly, 
some of them had a very low pI and others a very unusual high pI (Fig. 6B). In general, activity staining with TMA $+\alpha$-naphthol was less effective in 2D-gels when compared to 1D-gels (Fig. 6A and B). Studies with T. versicolor laccase (chapter 4) suggests that this is due to high urea amounts in the rehydration buffer used for iso-electric focusing. Urea appears to inhibit laccase activity.

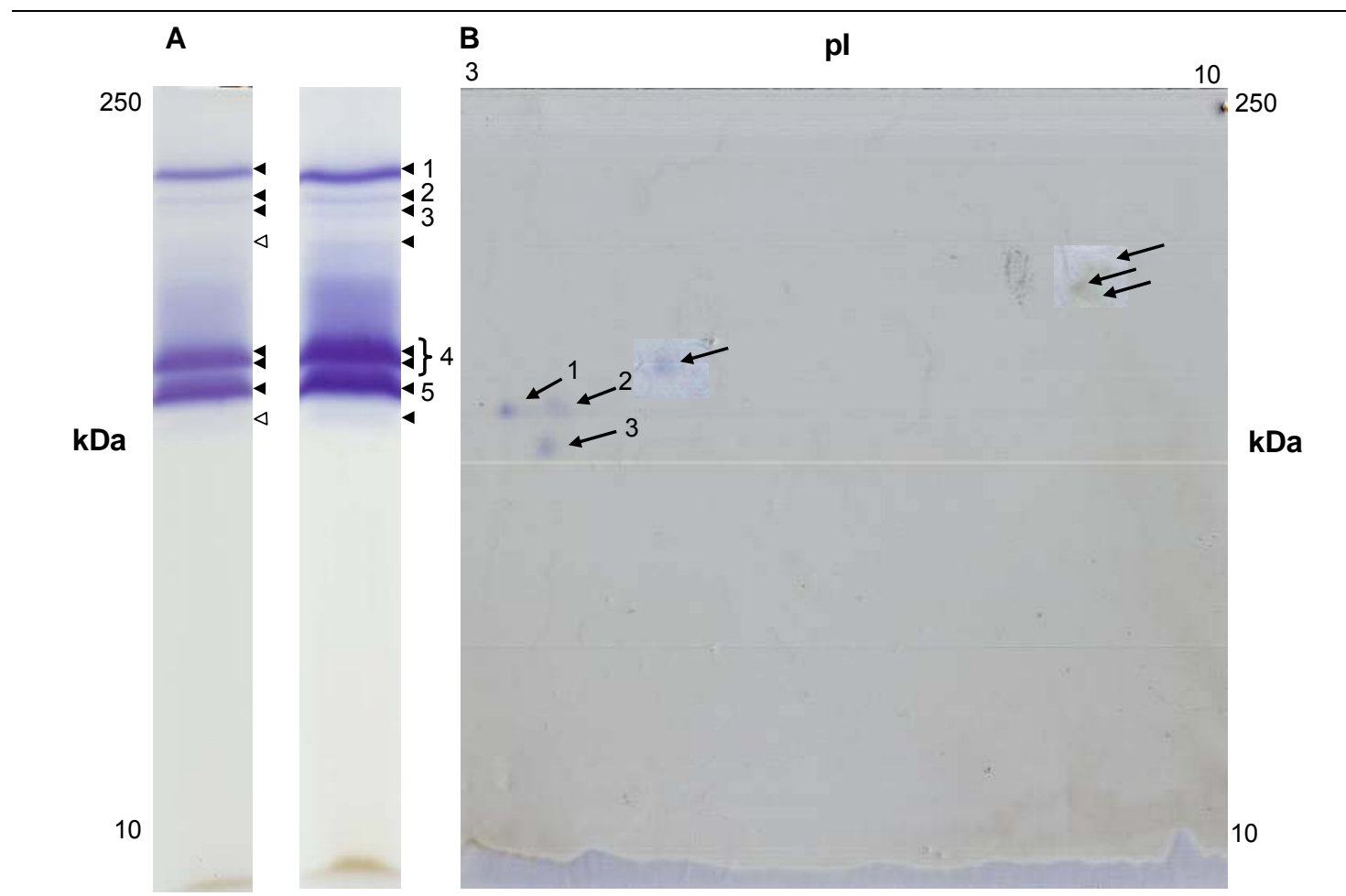

Fig. 6 A. In-gel staining of $C$. cinerea supernatant proteins from a 3 day-old copper-induced $100 \mathrm{ml}$ YMG/T standing culture grown at $37^{\circ} \mathrm{C}$. Laccase activity within the supernatant at this time point was $35 \mathrm{mU} / \mathrm{ml}$. Proteins from the supernatant were 83 times concentrated and each 34.0 and $17.0 \mu 1$ (corresponding to 50 and $100 \mathrm{mU}$ enzyme activities, respectively) were loaded on a $12 \%$ polyacrylamide gel that were run at $30 \mathrm{~mA}$ in electrode buffer afterwards. The gel was stained with $9.7 \mathrm{mM} \alpha$-naphthol, $8.9 \mathrm{mM}-\mathrm{N}, \mathrm{N}, \mathrm{N}$ ',N'-tetramethyl-p-phenylene diamine for 15 minutes. Note that this supernatant came from another culture than that analyzed in Fig 1-3. The open triangle in Fig. A marks the presence of faint phenoloxidase activity in the original picture that can be better visualized by modifying the contrast in Adobe photoshop (not shown). Filled triangles mark better visible phenoloxidase bands.

B. 2D-gel of $250 \mathrm{mU}$ enzyme activity present in $83 \mu \mathrm{l}$ of concentrated sample from the same culture as shown in A. Spots with laccase activities are marked with arrows. To better visualize some of the spots, the contrast and brightness have been increased for some areas of the scanned gel by Adobe Photoshop. Bands (A) and spots (B) labeled with numbers were cut from the gel for ESI-LC-MS analysis. In Sample 4, two closely located bands were taken together.

Generally,1D and 2D-gels can be used to identify the individual PO's by ESI-LC-MS analysis. To this end, single bands from the 1D-gels and single spots from the 2D-gel can 
be cut out of the gels. Removal of the stain is required for efficient in gel digestion by trypsin for the subsequent ESI-LC-MS analysis of the peptides generated following the protocol of Havlis et al. (2003). Upon digestion, peptides are eluted from gel slices and submitted to ESI-LC-MS analysis (see Material and methods).

In this work, native staining with TMA $+\alpha$-naphthol was thought to be useful for the two reasons, first because of its high sensitivity in detection of PO's (Fig. 1) and secondly because of the easy removal of the blue color (Fig. 3). However, even with several washing rounds (3 times) with distilled water to purify gel from all staining, in ESI-LCMS no PO peptides or any other proteins were identified. Visibly by eye, no stain were left in the gel pieces.

To solve this problem by staining, $5.0 \mu \mathrm{g}$ of purified laccase Lcc1 from C. cinerea (kindly provided by S. Kilaru) per lane were separated on parallel running 1D gels. One gel with 5 lanes loaded with Lcc1 was stained with TMA $+\alpha$-naphthol and a parallel gel with 4 lanes loaded with Lcc1 was stained with Coomassie. Stained bands were cut from the gels and staining eliminated by washing with distilled water (3 times). Excised gel pieces were digested by trypsin (see Materials and methods) and analyzed by ESI-LCMS (Table 2).

Table 2. Peptide identification by ESI-LC-MS of $C$. cinerea Laccase Lcc1 stained in-gel either by TMA $+\alpha$-naphthol or Coomassie. ${ }^{1}$

\begin{tabular}{|c|c|c|c|c|c|c|}
\hline $\begin{array}{c}\text { Peptides identified by ESI- } \\
\text { LC-MS }\end{array}$ & $\begin{array}{l}\text { Peptide } \\
\text { score }\end{array}$ & Protein identification & $\begin{array}{l}\text { Total } \\
\text { score }\end{array}$ & $\begin{array}{c}\text { Coverage } \\
\%\end{array}$ & pI & $\begin{array}{l}\text { MW } \\
\text { kDa }\end{array}$ \\
\hline \multicolumn{7}{|c|}{ Native staining with TMA $+\alpha$-naphthol } \\
\hline R.LQIFTGQR.Y & 21 & $\begin{array}{l}\text { Coprinopsis cinerea } \\
\text { Lcc } 1\end{array}$ & 21 & 1 & 5.17 & 58.6 \\
\hline \multicolumn{7}{|l|}{ Coomassie staining } \\
\hline $\begin{array}{l}\text { R.LQIFTGQR.Y } \\
\text { R.FQLGFSGGR.F } \\
\text { R.SAGSSTYNFVNPVK.R }\end{array}$ & $\begin{array}{l}23 \\
27 \\
39\end{array}$ & $\begin{array}{l}\text { Coprinopsis cinerea } \\
\text { Lcc1 }\end{array}$ & 88 & 5 & 5.17 & 58.6 \\
\hline \multicolumn{7}{|c|}{$\begin{array}{l}\text { 'Database searches of the mass spectra were performed with the own database containing } 17 \text { laccase sequences fror } \\
\text { Coprinopsis cinerea as annotated by S. Kilaru and proteins deduced from the genomes of C. cinerea an } \\
\text { Phanerochaete chrysosporium, and the entries in the SwissProt and the NCBI databases. }\end{array}$} \\
\hline \multicolumn{7}{|c|}{$\begin{array}{l}\text { Bands from TMA }+\alpha \text {-naphthol staining resulted in poor identification of laccase Lcc } \\
\text { with an insignificant score of } 21 \text { and a low sequence coverage of } 1 \% \text { (off-line } \mathrm{MASCO}^{-}\end{array}$} \\
\hline
\end{tabular}


Kilaru). In contrast, parallel bands excised from the Coomassie stained gel resulted in clear identification of $C$. cinerea laccase Lcc1 with the significant score of 88 and a coverage of $5 \%$ (Table 2 ).

By the positive result of identification of the purified Lcc1 from Coomassie stained gels, further attempts to identify unknown PO's from $C$. cinerea were undertaken with a Coomassie stained 1D-gel of separated proteins from a culture supernatant (Fig. 7). To identify positions of PO's in this Coomassie stained gel, a parallel gel from the same run was stained with TMA $+\alpha$-naphthol for detection of PO activities (Fig. 7).

$1 \mathrm{~mm}$ wide slices (S1 to S6) were cut at the positions corresponding to the bands with PO activities, in the native stained gel. The gel slices were washed and digested by trypsin and the eluted peptides were analyzed by ESI-LC-MS (Fig. 7B).

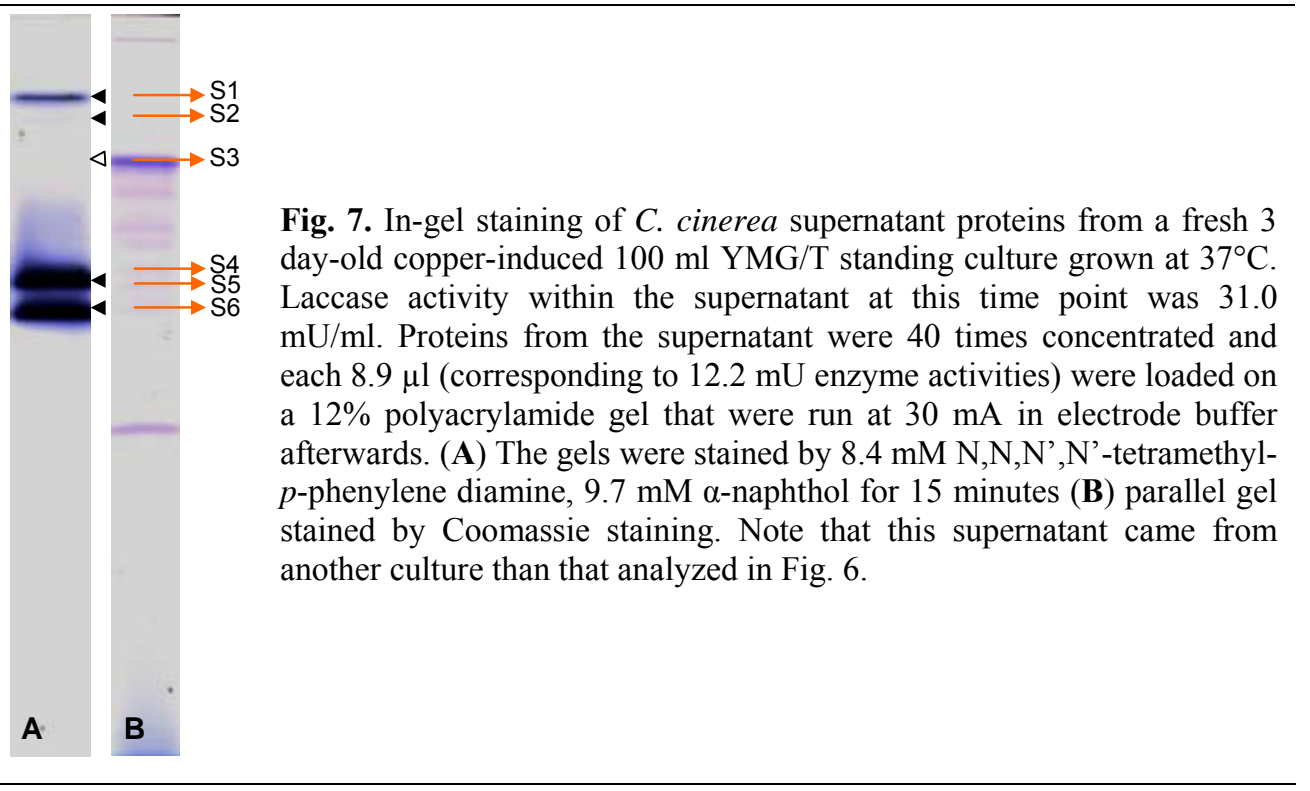

With the 6 different gel slices analyzed, samples S2 to S6 gave positive hits in MASCOT analysis with the offline database containing the SNAP annotated C. cinerea genome and additional 17 C. cinerea laccases as annotated by S. Kilaru. All hits were either known proteins from C. cinerea (Lcc1, Lcc10, Lcc14, CIP) or SNAP-predictions from the annotated C. cinerea genome. When Blasting the SNAP-hits to the NCBI database, all identified proteins from other fungi were identified. Where protein functions were known, they were all secerated enzymes (proteases, mannose, lipase, glyoxal oxidase, 
Table 3). From this, I can conclude that the sample analysis was well performed and that the results obtained were reliable.

Laccase Lcc1 was identified in samples 2 and 6 (Table 3). By the large size differences of the bands in the gel shown Fig. 7, possibly the band in S6 represents a Lcc1 monomer and the band in S2 a Lcc1 multimer. Laccases are known to occur in monomeric, dimeric and tetrameric forms (Claus 2003). Moreover in S2, Lcc14 was identified albeit at a lower probability (Lcc14: total score 45, coverage 2\% and Lcc1: total score 210, coverage $5 \%$, Table 3 ).

Regarding phenoloxidases activities, as another type of phenoloxidases than laccase, the well known C. cinerea peroxidase CIP (Baunsgaard et al. 1993) was found in highest probability in sample S6 (total score 160, coverage 9\%). However, since $\mathrm{H}_{2} \mathrm{O}_{2}$ dependent (Stajic et al. 2004) this enzyme will not have been the reason of substrate staining in band S6 (Fig. 7). Thus the staining in band S6 (Fig. 7) is likely due to Lcc1 activity.

In slice S5, laccase Lcc10 has been identified with a high significance (total score 84, coverage $4 \%$, Table 3). This is particularly interesting since Kilaru (2006) could detect in C. cinerea active laccases for ten of the 17 different laccase genes of $C$. cinerea but amongst these were not Lcc10 (Kilaru 2006). By cDNA analysis of gene Lcc10, only incorrectly spliced transcripts were found in shaken cultures, with $0.1 \mathrm{mM} \mathrm{CuSO}_{4}$ that had no enzymatic activity. Here, cultures were standing cultures. Further studies need to reveal whether the difference in laccase behavior is due to alternate splicing for regulatory purposes where introns are not spliced out or not correctly spliced out. Alternative splicing of transcripts appears to be common in basidiomycetes, particularly with those genes encoding enzymes participating in degradation of liginocellulose (Galagan et al. 2005).

In bands S1 and S2, no enzyme with PO activity was detected. In conclusion, further tests on protein identification have to be performed in the future. First trials with 2D-gel electrophoresis showed that single spots can be identified with high significance values in $>90 \%$ of tested spots (M. Zomorrodi, A. Majcherczyk personal communication). 
Table 3. Peptide identification of phenoloxidases from a three day-old copper-induced culture supernatant of C. cinerea by ESI-LC-MS. A Coomassie stained gel was used (Fig. 7B). ${ }^{1}$

\begin{tabular}{|c|c|c|c|c|c|c|c|}
\hline $\begin{array}{l}\text { Sample } \\
\text { protein }\end{array}$ & $\begin{array}{c}\text { Peptides identified by ESI-LC- } \\
\text { MS }\end{array}$ & $\begin{array}{l}\text { Peptide } \\
\text { score }\end{array}$ & $\begin{array}{c}\text { Protein } \\
\text { identification }\end{array}$ & $\begin{array}{l}\text { Total } \\
\text { score }\end{array}$ & $\begin{array}{c}\text { Coverage } \\
\%\end{array}$ & pI & $\begin{array}{l}\text { MW } \\
\text { kDa }\end{array}$ \\
\hline S1 ${ }^{*}$ & - & - & - & - & - & - & - \\
\hline $\begin{array}{l}\text { S2 } \\
\text { P1 }\end{array}$ & $\begin{array}{l}\text { R.LQIFTGQR.Y } \\
\text { R.FQLGFSGGR.F } \\
\text { R.SAGSSTYNFVNPVKR.D } \\
\text { R.SAGSSTYNFVNPVKR.D }\end{array}$ & $\begin{array}{l}40 \\
36 \\
89 \\
45\end{array}$ & $\begin{array}{l}\text { Coprinopsis cinerea } \\
\text { Lcc1 }\end{array}$ & 210 & 5 & 5.17 & 58 \\
\hline P2 & SAGSSTYNFVNPVQR & 45 & $\begin{array}{l}\text { Coprinopsis cinerea } \\
\text { Lcc14 }\end{array}$ & 45 & 2 & 6.02 & 56 \\
\hline P3 & $\begin{array}{l}\text { R.VSFPQNGGTVSFPNPR.Y } \\
\text { R.AEDGEYIVEK.Y } \\
\text { R.VTYIGLAASLR.D } \\
\text { K.IITIAAGNDGSR.G }\end{array}$ & $\begin{array}{l}59 \\
51 \\
52 \\
49\end{array}$ & $\begin{array}{l}\text { Subtilisin-like } \\
\text { protease (Pleurotus } \\
\text { ostreatus): } \\
\text { CAG25549 }\end{array}$ & 441 & 13 & 4.91 & 97 \\
\hline P4 & $\begin{array}{l}\text { R.QLNVGGWSLDSTFGVR.L } \\
\text { R.ILDPVTFDTIK.V } \\
\text { K.CTDACFNAGYR.L }\end{array}$ & $\begin{array}{l}69 \\
61 \\
54\end{array}$ & $\begin{array}{l}\text { Related to glyoxal } \\
\text { oxidase precursor } \\
\text { (Neurospora crassa): } \\
\text { CAE76318 }\end{array}$ & 144 & 14 & 4.52 & 97 \\
\hline P5 & $\begin{array}{l}\text { K.SFADIASMGATTVR.V + O } \\
\text { (M) }\end{array}$ & 61 & $\begin{array}{l}\text { CEL4b mannanase } \\
\text { (Agaricus bisporus): } \\
\text { CAA90423 }\end{array}$ & 99 & 10 & 5.75 & 43 \\
\hline $\begin{array}{l}\mathbf{S 3} \\
\mathrm{P} 1\end{array}$ & $\begin{array}{l}\text { R.MYHSEVSLLADGR.F } \\
\text { R.GCLVEAVGR.Y } \\
\text { R.MYHSEVSLLAR.T + O (M) } \\
\text { R.VSLLAAASSTHGNTMGAR.Y }\end{array}$ & $\begin{array}{l}68 \\
54 \\
46 \\
35\end{array}$ & $\begin{array}{l}\text { Related to glyoxal } \\
\text { oxidase precursor } \\
\text { (Neurospora crassa): } \\
\text { CAE76318 }\end{array}$ & 364 & 14 & 4.52 & 97 \\
\hline $\mathrm{P} 2$ & $\begin{array}{l}\text { R.WALVGAFNPFFR.N } \\
\text { R.STGEVLFSTK.D } \\
\text { R.VSHAQIPMHIR.G + O (M) }\end{array}$ & $\begin{array}{l}51 \\
36 \\
32\end{array}$ & $\begin{array}{l}\text { Hypothetical protein } \\
\text { (Neurospora crassa } \\
\text { N150): XP_959217 }\end{array}$ & 120 & 5 & 5.41 & 105 \\
\hline P3 & R.TPSAITVGATDIQDGK.A & 80 & $\begin{array}{l}\text { Serine proteinase } \\
\text { (Agaricus bisporus): } \\
\text { CAA74137 }\end{array}$ & 80 & 6 & 5.80 & 262 \\
\hline $\begin{array}{l}\text { S4 } \\
\mathrm{P} 1\end{array}$ & $\begin{array}{l}\text { K.LPFGPSTDGIVVTR.L } \\
\text { K.APDLLGYAPFK.L }\end{array}$ & $\begin{array}{l}77 \\
56\end{array}$ & $\begin{array}{l}\text { Carotenoid ester } \\
\text { lipase precursor } \\
\text { (Pleurotus sapidus): } \\
\text { CAH17527 }\end{array}$ & 167 & 6 & 5.67 & 65 \\
\hline & $\begin{array}{l}\text { R.GAGPNNIQQADMK.A } \\
\text { K.AYAPAALSFR.L }\end{array}$ & $\begin{array}{l}67 \\
49\end{array}$ & $\begin{array}{l}\text { Metalloprotease } \\
\text { (Pleurotus ostreatus): } \\
\text { AAU94648 }\end{array}$ & 145 & 10 & 4.56 & 30 \\
\hline & $\begin{array}{l}\text { R.IQQSMATNGQFDFTSPR.Y + } \\
\mathrm{O}(\mathrm{M})\end{array}$ & 73 & $\begin{array}{l}\text { Hypothetical protein } \\
\text { UM00822.1 } \\
\text { (Ustilago maydis } \\
\text { 521): XP } 756969\end{array}$ & 125 & 13 & 7.72 & 42 \\
\hline
\end{tabular}




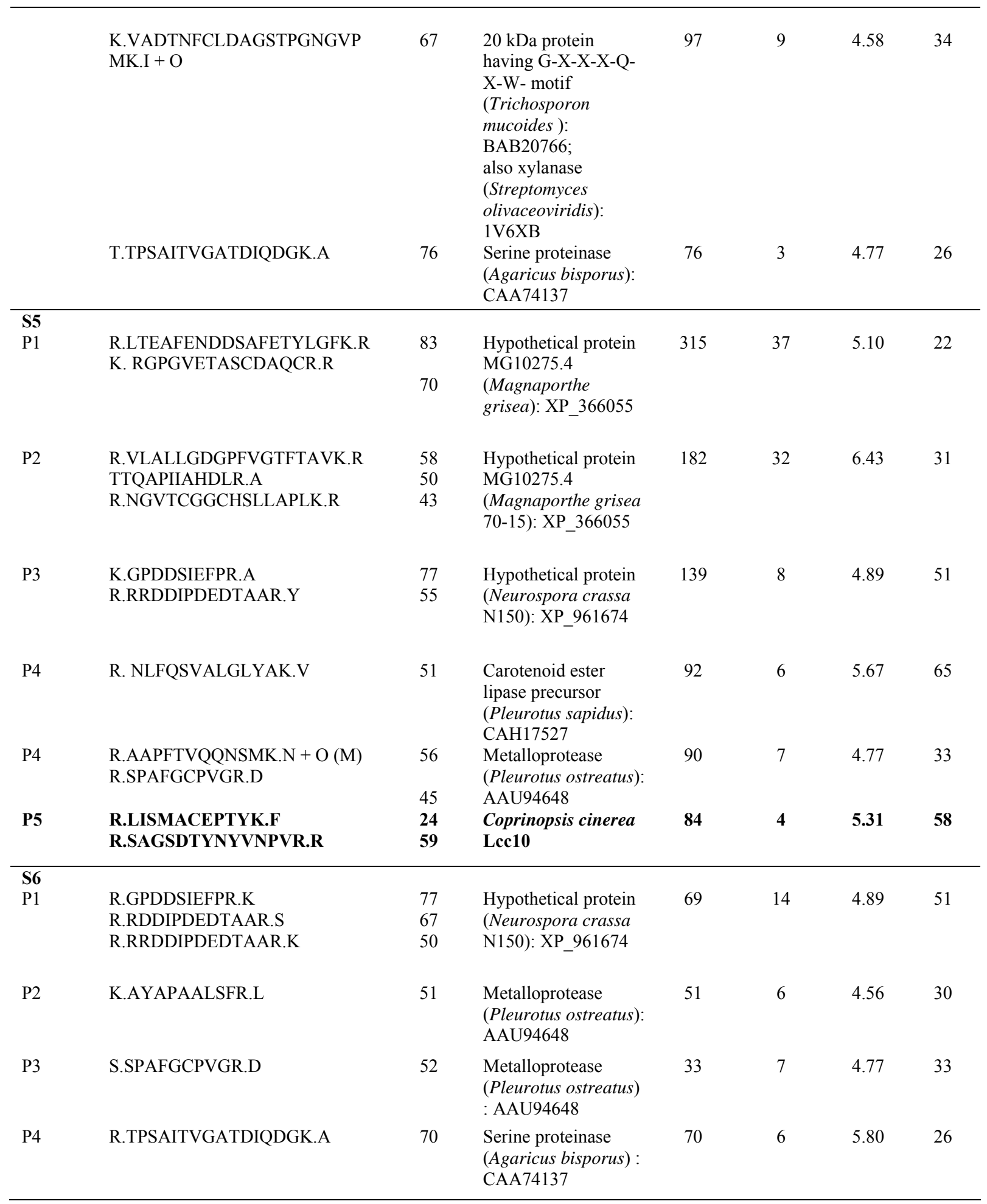


Chapter 3. Native staining

\begin{tabular}{|c|c|c|c|c|c|c|c|}
\hline P5 & $\begin{array}{l}\text { R.LQIFTGQR.Y } \\
\text { R.AGILVNGVHGPLIR.G } \\
\text { R.SAGSSTYNFVNPVK.R } \\
\text { R.GLAGTFANGVNSAILR.Y }\end{array}$ & $\begin{array}{l}40 \\
31 \\
36 \\
29\end{array}$ & $\begin{array}{l}\text { Coprinopsis cinerea } \\
\text { Lcc1 }\end{array}$ & 136 & 9 & 5.17 & 58 \\
\hline P5 & $\begin{array}{l}\text { R.LEFLTGR.Y } \\
\text { R.MSVLGFDR.G + O (M) } \\
\text { R.MSSNEVMGQR.Y + O (M) }\end{array}$ & $\begin{array}{l}47 \\
41 \\
52\end{array}$ & $\begin{array}{l}\text { Peroxidase } \\
\text { precursor (CIP) }\end{array}$ & 160 & 9 & 4.6 & 38 \\
\hline
\end{tabular}

${ }^{1}$ Database searches of the mass spectra were performed with the own database containing 17 laccase sequences from Coprinopsis cinerea as annotated by S. Kilaru and proteins deduced from the genomes of C. cinerea and Phanerochaete chrysosporium, and the entries in the SwissProt and the NCBI databases.

* In sample S1, human keratin was identified which is a common and hard to avoid contamination in such analysis.

\subsubsection{Conclusion}

Several substrates, coreactants and combinations of substrates and coreactants were extensively tested for in-gel staining of culture liquid proteins of two basidiomycetes $C$. cinerea and T. versicolor. The combinations of TMA $+\alpha$-naphthol, MBTH + TMA and $\mathrm{MBTH}+\mathrm{DAN}$ could detect the maximum number of PO's after electrophoretic separation in 1D-gels. TMA $+\alpha$-naphthol was the most effective and most sensitive in detection of PO's. However, substrate based staining adversely effected the identification of PO's by mass spectrometry. This problem can easily be solved by staining parallel gels with Coomassie and with TMA $+\alpha$-naphthol, respectively, and by excising bands from the Coomassie gel at the corresponding sites for PO's as detected in the native stained gel. With such bands from Coomassie staining, proteins were successfully identified in ESI-LC-MS analysis. Amongst these were three different laccases from C. cinerea (Lcc1, Lcc10 and Lcc14) and the peroxidase CIP and a potential glyoxal oxidase.

\subsection{References}

Ander P., and Marzullo L. (1997). Sugar oxidoreductases and veratryl alcohol oxidase as related to lignin degradation. Journal of Biotechnology 3:115-131.

Baunsgaard L., Dalboge H., Houen G., Rasmussen E.M., and Welinder K.G. (1993). Amino acid sequence of Coprinus macrorhizus peroxidase and cDNA sequence encoding Coprinus cinereus peroxidase. A new family of fungal peroxidases. European Journal of Biochemistry 1:605-611.

Blum H., Beier H., and Gross H.J. (1987). Improved silver staining of plant proteins, RNA and DNA in polyacrylamide gels. Electrophoresis 8:93-99. 
Candiano G., Bruschi M., Musante L., Santucci L., Ghiggeri G.M., Carnemolla B., Orecchia P., Zardi L., and Righetti P.G. (2004). Blue silver: A very sensitive colloidal Coomassie G-250 staining for proteome analysis. Electrophoresis 25:1327-1333.

Claus H. (2003). Laccases and their occurrence in prokaryotes. Archives of Microbiology 3:145150.

Dicko M.H., Hilhorst R., Gruppen H., Laane C., van Berkel W.J.H., and Voragen A.G.J. (2002). Zymography of monophenolase and $o$-diphenolase activities of polyphenol oxidase. Analytical Biochemistry 306:336-339.

Dong J.L. and Zhang Y.Z. (2004). Purification and characterization of two laccase isoenzymes from a ligninolytic fungus Trametes gallica. Preparative Biochemistry \& Biotechnology 34:179-194.

Dong J.L., Zhang Y.W., Zhang R.H., Huang W.Z., and Zhang Y.Z. (2005). Influence of culture conditions on laccase production and isozyme patterns in the white rot fungus Trametes gallica. Journal of Basic Microbiology 45 (3): 190-198 2005

Eggert C., Temp U., Dean J.F.D., and Eriksson K.E.L. (1996). A fungal metabolite mediates degradation of non-phenolic lignin structures and synthetic lignin by laccase. FEBS Letters 391:144-148.

Galagan J.E., Calvo S.E., Borkovich K.A., Selker E.U., Read N.D., Jaffe D., and FitzHugh W. et al. (2003). The genome sequence of the filamentous fungus Neurospora crassa. Nature 422:859-868.

Granado J.D., KerteszChaloupkova K., Aebi M., and Kües U. (1997). Restriction enzyme mediated DNA integration in Coprinus cinereus. Molecular \& General Genetics 256(1): 2836

Havlis J., Thomas H., Sebela M., and Shevchenko A. (2003). Fast-response proteomics by accelerated in-gel digestion of proteins. Analytical Chemistry 75:1300-1306.

Hoopes J.T., and Dean J.F.D. (2001). Staining electrophoretic gels for laccase and peroxidase activity using 1,8-diaminonaphthalene. Analytical Biochemistry 293:96-101.

Hüttermann A., and Volger C. (1973). Induction of aryl B-glucosidase in Fomes annosus by cellobiose. Archiv fur Mikrobiologie 93:195-204.

Khindaria A., Yamazaki I., and Aust S.D. (1995). Veratryl alcohol oxidation by lignin peroxidase. Biochemistry 34:16860-16869.

Kilaru S. (2006). Identification of fungal multi-copper oxidase gene families: Overexpression and characterization of Coprinopsis cinerea laccases for applications in biotechnology, $\mathrm{PhD}$ thesis, University of Göttingen, Germany. 
Lang C. (2004). Redoxenzyme bei Heterobasidion annosum. Master thesis, Institute of Forest Botany, Faculty of Forest Science and Forest Ecology, Georg-August-University Gottingen, Gottingen, Germany

Laemmli U.K. (1970). Cleavage of structural proteins during assembly of head of bacteriophage T4. Nature 227:680-685.

Leonowicz A., Matuszewska A., Luterek J., Ziegenhagen D., Wojtas-Wasilewska M., Cho N.S., Hofrichter M., and Rogalski J. (1999). Biodegradation of lignin by white rot fungi. Fungal Genetics and Biology 27:175-185.

Matsumura E., Yamamoto E., Numata A., Kawano T., Shin T., and Murao S. (1986). Structures of the laccase catalyzed oxidation products of hydroxy benzoic acids in the presence of ABTS (2,2'-Azino-Di-(3-Ethylbenzothiazoline-6-Sulfonic Acid)). Agricultural and Biological Chemistry 50:1355-1357.

Majcherczyk A., Johannes C., and Hüttermann A. (1999). Oxidation of aromatic alcohols by laccase from Trametes versicolor mediated by the 2,2'-azino-bis-(3-ethylbenzothiazoline-6sulphonic acid) cation radical and di-cation. Applied Microbiology and Biotechnology 51:267276.

Rescigno A., Sanjust E., Montanari L., Sollai F., Soddu G., Rinaldi A.C., Oliva S., and Rinaldi A. (1997a). Detection of laccase, peroxidase, and polyphenol oxidase on a single polyacrylamide gel electrophoresis. Analytical Letters 30:2211-2220.

Smith M., Thurston C.F., and Wood D.A. (1997). Fungal laccases: Role in delignification and possible industrial application. In: Multi-copper oxidases (Messerschmidt A. ed.), World Scientific Publishing Co. Pte. Ltd., Singapore, pp. 201-224.

Stajic M., Persky L., Cohen E., Hadar Y., Brceski I., Wasser S.P., and Nevo E. (2004). Screening of laccase, manganese peroxidase, and versatile peroxidase activities of the genus Pleurotus in media with some raw plant materials as carbon sources. Applied Biochemistry and Biotechnology 3:155-164.

Sterjiades R., Dean J.F.D., Gamble G., Himmelsbach D.S., and Eriksson K.E.L. (1993). Extracellular laccases and peroxidases from Sycamore maple (Acer pseudoplatanus) cell suspension cultures - reactions with monolignols and lignin model compounds. Planta 190:75-87.

Wariishi H., Valli K., and Gold M.H. (1992). Manganese(II) oxidation by manganese peroxidase from the basidiomycete Phanerochaete chrysosporium - kinetic mechanism and role of chelators. Journal of Biological Chemistry 267:23688-23695.

Xiao Y.Z., Tu X.M., Wang J., Zhang M., Cheng Q., Zeng W.Y., and Shi Y.Y. (2003). Purification, molecular characterization and reactivity with aromatic compounds of a laccase from basidiomycete Trametes sp strain AH28-2. Applied Microbiology and Biotechnology 60:700-707. 


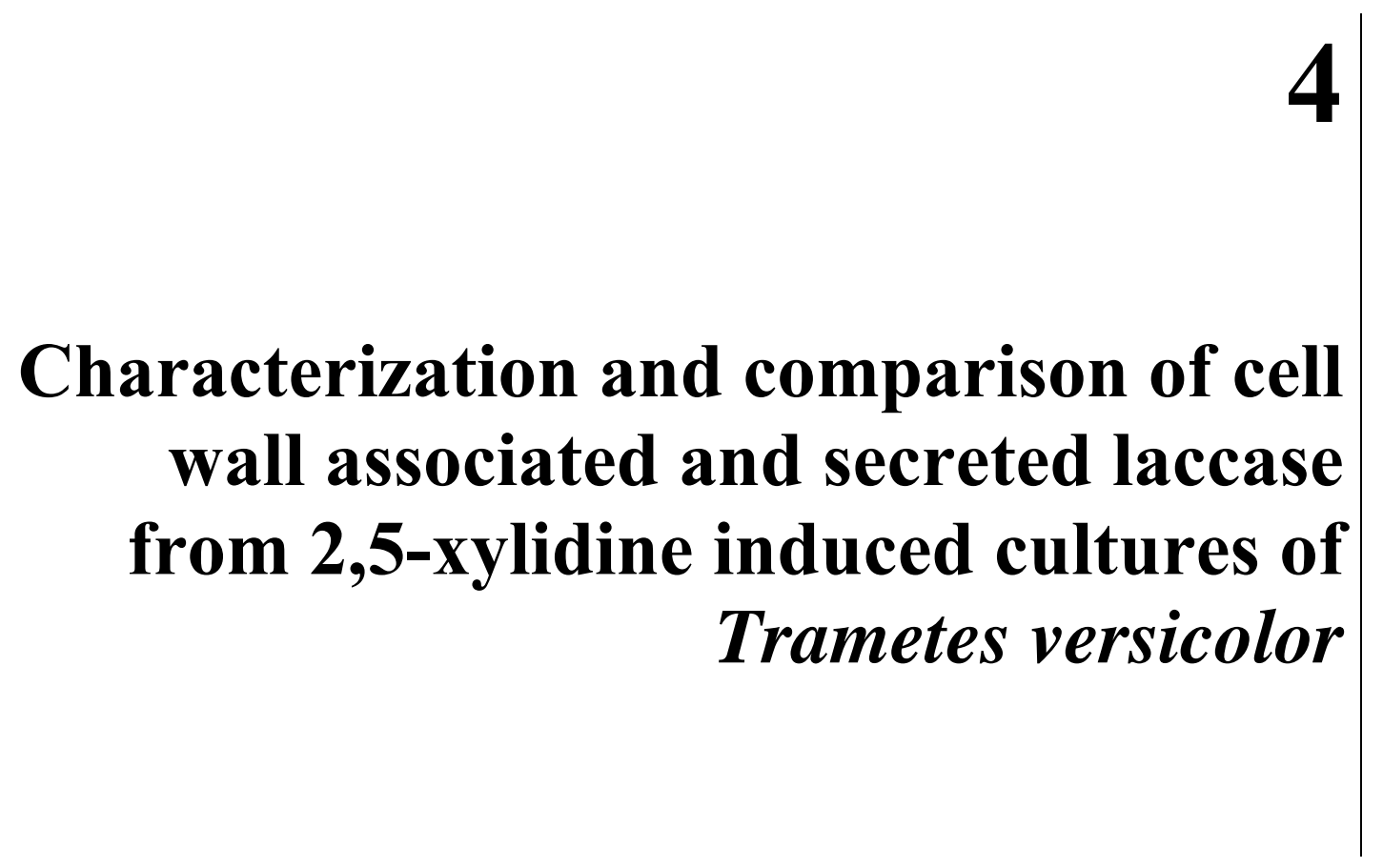





\title{
4. Characterization and comparison of cell wall associated and secreted laccase from 2,5-xylidine induced cultures of Trametes versicolor
}

\author{
4.1 Abstract \\ In this study, I isolated and characterized supernatant and cell wall-associated laccase \\ from 2,5-xylidine induced cultures of $T$. versicolor. The supernatant laccase was purified \\ by two chromatographic steps: DEAE-Sepharose and Mono-Q. It was identified by ESI- \\ LC-MS analysis as the already known Laccase III. Supernatant and cell wall-associated \\ laccase were characterized for different substrates, inhibitors, temperature optimum and \\ stability. Cell wall-laccase was more tolerant to inhibitors than supernatant laccase, while \\ both forms had temperature optima of approximately $50^{\circ} \mathrm{C}$. The cell wall associated \\ laccase was more stable at higher temperature as compared to the supernatant enzyme.
}

\subsection{Introduction}

Laccases (benzenediol oxygen oxidoreductase, EC 1.10.3.2), first isolated from the Japanese tree Rhus vernicifera (Yoshida 1883), are known to exist in a wide range of plants, wood-rotting basidiomycetous fungi, some ascomycetes, bacteria and insects. Laccases belong to the blue multi-copper oxidase $(\mathrm{bmCuO})$ family and have commonly a molecular mass of about $70 \mathrm{kDa}$ (Smith et al. 1997). They are used for several industrial applications such as pulp delignification (Sealey et al. 1998), bleaching agents for textiles and dyes, enzymatic conversion of chemical intermediates, and bioremediation of soils and water (Baldrian 2005). In plants, particularly in trees, laccases are proposed to catalyze the initial steps of lignification (Gavnholt and Larsen 2002). In fungi, laccases catalyze reactions in lignin degradation (Leonowicz et al. 1999), act in detoxification of phenols produced as byproducts during degradation of lignin (Eggert et al. 1997) and these enzymes are also associated with functions like fungal

\footnotetext{
Abbreviations: ABTS [2,2'-azino-bis(3-ethylenbenzothiazoline-6-sulfonic-acid)], TMA (N,N,N',N`-tetramethyl-1,4phenylenediammonium dichloride), MBTH (3-methyl-2-benzothiazolinon-hydrazone-hydrochloride monohydrate), DHPPA (3,4-dihydroxyhydrocinnamic acid), SGZ (syringaldazine)
} 
virulence in Cryptococcus neoformans (Zhu et al. 2001), pigment formation (Langfelder et al. 2003) and fruiting body development (Kües and Liu 2000).

During the past years, several supernatant laccases have been detected and characterized from different strains of Trametes versicolor. Three different isoenzymes (laccase I, II, and III) have been described from supernatants of T. versicolor. Laccase III was found to be the most abundantly secreted isoform and to be involved in lignin degradation (Morohoshi et al. 1987). Laccase IIIb from 2,5-xylidine-induced cultures of T. versicolor was isolated by Bertrand et al. (2002). Xiao et al. $(2003 ; 2004)$ purified and characterized the iso-enzyme laccases from Trametes sp. strain AH28-2 in culture supernatants and described them as laccase A and laccase B. Laccase A was found to constitute $85 \%$ of total enzyme while Laccase B was produced in presence of inducers. Laccase A might be a new member of the growing laccase family possessing important properties for industrial applications.

Besides the presence of laccases in the supernatant, they are also found to be associated with the outer sphere of the hypha. In the wood degrading basidiomycete Pycnoporus cinnabarinus, co-precipitation of gold particles with a phenolic laccase substrate showed a high concentration of enzyme at the apical tip region of hyphae and a lower concentration on the exterior sub-apical hyphal sheath (Jones et al. 1999). With the help of immuno-gold labeling methods, few redox enzymes have been localized to the cell walls of various fungi (Daniel 1994). However, the laccase(s) present in the cell wall of T. versicolor have never been characterized, neither in bound nor in free form after release from the cell wall.

In this study, supernatant laccase was isolated and purified from 2,5-xylidine induced cultures of $T$. versicolor and compared with cell wall associated laccase for substrate specificity, temperature optimum, temperature stability and inhibitor tolerance. The purified supernatant laccase from $T$. versicolor was identified by ESI-LC-MS analysis as the formerly described laccase III.

\subsection{Materials and methods}

\section{Fungal cultures and harvesting}

Trametes versicolor strain number 6 from the collection of the Institute of Forest Botany, Georg August Universität, Göttingen,were cultivated on basidiomycetes-medium (BSM, 
Hüttermann and Volger, 1973) with 1.5\% agar. Starter liquid cultures were prepared by inoculation of $100 \mathrm{ml} \mathrm{BSM}$ liquid medium in $500 \mathrm{ml}$ conical flasks with three agar pieces $\left(1 \mathrm{~cm}\right.$ in diameter) of the stock culture and cultivated stationary at $25^{\circ} \mathrm{C}$ in the dark. Mycelium of 14 days-old liquid cultures were gently disrupted using an UltraTurrax T25 (rod diameter $10 \mathrm{~mm}$; Janke \& Kunkel, IKA-Labortechnik, Germany) at 9,000 rpm for 1 minute under sterile conditions. Each $4 \mathrm{ml}$ of mycelium suspension were used to inoculate new $100 \mathrm{ml}$ BSM liquid cultures. Standing cultures of T. versicolor were induced after seven days of incubation with $100 \mu \mathrm{l} 0.5 \mathrm{M}$ 2,5-xylidine and incubated further for seven more days stationary at $25^{\circ} \mathrm{C}$ in the dark. The culture supernatants were harvested by vacuum filtration using filter paper (595 Round filter, $\varnothing$ 90 mm, Schleicher \& Micro Science GmbH, Germany).

\section{Cell wall sample preparation for enzyme characterization}

About $2 \mathrm{~g}$ of freshly collected mycelia form 2,5-xylidine induced cultures of $T$. versicolor were transferred in a $200 \mathrm{ml}$ Schott glass bottle containing $20 \mathrm{ml}$ of sodium acetate buffer (100 mM, pH 5.8). $1 \mathrm{mM}$ of PMSF (phenylmethanesulfonyl fluoride) was added to the buffer to avoid any protease activity and all steps were performed on ice. The sample was homogenized using an Ultra-Turrax T25 (rod diameter $10 \mathrm{~mm}$; Janke \& Kunkel, IKA-Labortechnik, Germany) at 24,000 rpm for 3 minutes. Homogenized samples were re-suspended in $20 \mathrm{ml}$ of sodium acetate buffer $(100 \mathrm{mM}, \mathrm{pH} \mathrm{5.8)}$ and incubated for $30 \mathrm{~min}$ to remove supernatant laccase activity. The pellet was collected by centrifugation at $600 \mathrm{~g}$ for $5 \mathrm{~min}$ at $4^{\circ} \mathrm{C}$. The same step was repeated for four more times.

\section{Enzyme activities}

Laccase activity in the liquid culture and also in the cell wall samples was measured by using different substrates (see below). One unit of laccase activity is defined as the amount of laccase that oxidize $1 \mu \mathrm{mol}$ substrate per minute.

Supernatant enzyme activities: The ABTS [2,2'-azino-bis(3-ethylenbenzothiazoline-6sulfonic-acid)] test was performed as described by Matsumura et al. (1986). The DMP (2,6-dimethoxyphenol) test was done as described by Wariishi et al. (1992). The 
syringaldazine (SGZ) test was done according to Slomczynski et al. (1995) and the guaiacol test was performed according to Eggert et al. (1996).

Cell wall bound enzyme activities (ABTS, DMP, SGZ and guaiacol test): Approximately $10.0 \mathrm{mg}$ of wet cell wall samples were incubated in $1.5 \mathrm{ml}$ plastic micro tubes for $30 \mathrm{~min}$ in $900 \mu$ l Universal Davis buffer (Stauff and Jaenicke 1964), pH 2.0 to 10.0. Thereafter, $100 \mu 1$ of $50 \mathrm{mM}$ ABTS was added to the plastic micro tubes and gently mixed every five seconds by inverting the tubes. The reaction was stopped by addition of $50 \mu 1$ of $50 \mathrm{mM}$ $\mathrm{NaN}_{3}$. The micro tubes were centrifuged for 10 seconds and change in absorbance was measured at $420 \mathrm{~nm}$. Samples without mycelia were used as control. The remaining sample pellet was dried at $105^{\circ} \mathrm{C}$ for two days and the dry weight of mycelium was measured. Mycelium bound laccase activity was calculated in $\mathrm{mU} / \mathrm{mg}$ dry weight. The same substrates [DMP $(0.3 \mathrm{mM}), \mathrm{SGZ}(0.05 \mathrm{mM})$ and guaiacol $(50 \mathrm{mM})]$ were used in laccase activity tests with cell walls as for the detection of supernatant laccase activity.

\section{Laccase stability in the supernatant}

Before performing enzyme purification steps, the stability of supernatant laccase was measured with $100 \mathrm{mM}$ sodium acetate buffer $\mathrm{pH} 5.0$ and $100 \mathrm{mM}$ potassium phosphate buffer $\mathrm{pH} 6.4$ at $0^{\circ} \mathrm{C}, 4^{\circ} \mathrm{C}, 24^{\circ} \mathrm{C}$ (room temperature). The culture supernatant was incubated in the respective buffers in a ratio of $1: 4$ at $0^{\circ} \mathrm{C}, 4^{\circ} \mathrm{C}, 24^{\circ} \mathrm{C}$ for 72 hours. In between, the laccase activity was measured using ABTS after $15 \mathrm{~min}, 30 \mathrm{~min}, 1 \mathrm{hr}, 3 \mathrm{hr}$, $6 \mathrm{hr}, 24 \mathrm{hr}$ and $72 \mathrm{hr}$ of incubation by ABTS.

\section{Supernatant laccase purification (ion-exchange chromatography)}

Culture filtrates were centrifuged at $4,000 \mathrm{~g}$ for 20 minutes at $4^{\circ} \mathrm{C}$. The supernatant $\mathrm{pH}$ was adjusted to 6.4 with $1 \mathrm{M}$ potassium phosphate buffer to a final concentration of 20 $\mathrm{mM}$ and was filtered with $1000 \mathrm{kDa}$ pore size polyether sulfone membrane using PAL filtration cassette (Ultrasette, Pall Corporation, New York, USA). The filtrate was loaded onto a $150 \mathrm{ml}$ DEAE-Sepharose FF column (10x200 mm, Amersham Pharmacia, Sweden) and the column was washed with $200 \mathrm{ml}$ of $20 \mathrm{mM}$ potassium phosphate buffer. The adsorbed proteins were eluted and fractionated by FPLC with a linear gradient of 1$30 \% 1 \mathrm{M} \mathrm{NaCl}$ in $20 \mathrm{mM}$ potassium phosphate buffer. Fractions containing laccase activity were pooled together and concentrated by ultra-filtration using $10 \mathrm{YM}$ pore size 
regenerated cellulose MWCO (Molecular Weight Cut Off) membrane (Amicon, 8550, USA) and washed 3 times with $20 \mathrm{ml}$ of $20 \mathrm{mM}$ potassium phosphate buffer.

The laccase was finally purified by FPLC (Amersham Biosciences, Germany) using a Mono-Q column (Amersham Biosciences, Germany) by applying $20 \mu 1$ of concentrated sample containing $65.8 \mu \mathrm{g}$ protein. Proteins bound to the Mono-Q column were eleuted by using a concentration gradient from 1-30\% $1 \mathrm{M} \mathrm{NaCl}$ (made in $20 \mathrm{mM}$ potassium phosphate $\mathrm{pH}$ 6.4) for 16 mins. In the following, $100 \% \mathrm{NaCl}$ was applied to the column for 5 mins for complete elution of all bound proteins. Specific activities of laccases were determined by calculating the enzymatic activity of laccase (see below) present in $1 \mathrm{mg}$ of total protein of a sample and the factor of purification by dividing the specific activity from each purification step with the one from the supernatant. The purity of collected fractions was checked by SDS-PAGE and the gels were stained with Coomassie (Candiano et al. 2004). Details of protein purification are given in Table 1.

\section{pI-determination}

The $\mathrm{pI}$ value of purified supernatant laccase was determined by isoelectric focusing in $5 \%$ polyacrylamide gels of a $\mathrm{pH}$ range of 2.5-6.5. Ready to use 5\% PAGE strips were cut in a dimension of $3 \times 10 \mathrm{~cm}$ and rehydrated in $76 \mu$ Pharmalyte, $\mathrm{pH} 2.5-5.0,51 \mu 1$ Pharmalyte, $\mathrm{pH}$ 4.0-6.5 (Amersham Biosciences, Germany) and $1873 \mu$ l distilled water. $3 \mathrm{~cm}$ long paper strip soaked with $0.1 \mathrm{M} \mathrm{H}_{2} \mathrm{SO}_{4}$ and $0.2 \mathrm{M}$ L-histidine were used as anode and cathode, respectively. The gels were pre-focused at $700 \mathrm{~V}, 3 \mathrm{~mA}$ and $3 \mathrm{~W}$ for $30 \mathrm{~min}$ and $10 \mu \mathrm{l}$ of sample containing $10 \mathrm{mU}$ of the enzyme activity were applied on $0.5 \times 0.5 \mathrm{~mm}$ size filter papers.

The gels were focused in two steps: sample entrance at $500 \mathrm{~V}, 3 \mathrm{~mA}, 3 \mathrm{~W}$ and sample separation at $2000 \mathrm{~V}, 6 \mathrm{~mA}, 6 \mathrm{~W}$. Gels were calibrated by IEF (isoelectric focusing) marker (pH range 2.5 to 6.5, Amersham Biosciences, Germany) which was run in a separate lane next to the sample. For native staining, gels were transferred to $100 \mathrm{mM}$ sodium acetate buffer $\mathrm{pH} 5.0$ for $30 \mathrm{~min}$. The buffer was replaced by $100 \mathrm{ml}$ of fresh buffer containing $10 \mathrm{mM} \mathrm{MBTH}$ and $10 \mathrm{mM}$ DHPPA to visualize laccase activity (chapter 3). Stained gels were scanned at 300 dpi resolution (Microtek, TMA 1600, Germany). 


\section{Laccase inhibition}

Inhibition of the supernatant and the cell wall associated laccase activity was tested against the three inhibitors $\mathrm{NaN}_{3}(0.01,0.1$, and 1.0), $\mathrm{NaF}(0.1,1.0$ and $10 \mathrm{mM})$ and EDTA (10.0 and $20.0 \mathrm{mM}) . \quad 100 \mu \mathrm{l}$ of purified supernatant laccase containing approximately $100 \mathrm{mU}$ of enzyme activity was incubated for 30 minutes in $800 \mu \mathrm{l}$ of 100 $\mathrm{mM}$ sodium acetate buffer $\mathrm{pH} 5.0$ containing an inhibitor at desired concentrations at room temperature. Laccase activity was measured after addition of $100 \mu 1$ of $50 \mathrm{mM}$ ABTS in a spectrophotometer at $420 \mathrm{~nm}$ in a kinetic mode.

Cell wall-associated laccase activity was measured by using $10 \mathrm{mg}$ wet weight of cell wall samples which were incubated at room temperature in plastic micro tubes in $900 \mu 1$ of $100 \mathrm{mM}$ sodium acetate buffer $\mathrm{pH} 5.0$ containing an inhibitor at desired concentrations. Thereafter, $100 \mu \mathrm{l}$ of $50 \mathrm{mM}$ ABTS was added and samples were gently mixed each five seconds by inverting the tubes. The laccase reaction was stopped after 3 min by addition of $50 \mu \mathrm{l}$ of $50 \mathrm{mM} \mathrm{NaN}_{3}$. The microtubes were centrifuged for 10 seconds at $16,000 \mathrm{~g}$ and change in absorbance was measured immediately at $420 \mathrm{~nm}$ by subtracting the control values. Samples without mycelia were used as control. The dry weights of the sample pellets were measured after drying samples at $105^{\circ} \mathrm{C}$ for two days. Mycelium-bound laccase activity was calculated in $\mathrm{mU} / \mathrm{mg}$.

\section{Native protein sample preparation}

The supernatant obtained from 14 days old cultures was centrifuged for $20 \mathrm{~min}$ at 3,000 $\mathrm{g}$ and concentrated by ultra-filtration with $3 \mathrm{kDa}$ MWCO polyether sulfone membrane (Vivaspin, Vivascience AG, Hannover Germany) at 3,000 g to obtain at least at $20 \mathrm{U} / \mathrm{ml}$ concentration of laccase activity.

\section{D-SDS-PAGE and staining}

1D-SDS-PAGE electrophoresis was performed using $12 \times 12 \mathrm{~cm}$ discontinuous $12 \%$ acrylamide gels with $0.025 \mathrm{M}$ Tris base, $\mathrm{pH} 8.3$ as electrode buffer (Laemmli 1970). Protein samples were mixed in sample buffer $(0.06 \mathrm{M}$ Tris-Cl, $\mathrm{pH} 6.8,10 \%$ glycerol, $0.025 \%$ bromphenol blue). Total protein concentrations were measured with Coomassie plus protein assay reagent (Pierce, Rockford USA) using bovine serum albumin (BSA) as a standard. $20 \mu \mathrm{l}$ samples with $1 \mu \mathrm{g} / \mu \mathrm{l}$ protein were loaded and run at $10-15^{\circ} \mathrm{C}$ at a 
constant current of $30 \mathrm{~mA}$. For silver staining, the gels were fixed in $30 \%$ methanol with $12 \%$ acetic acid and $0.05 \%$ formaldehyde overnight and stained as described by Blum et al (1987). For colloidal Coomassie blue staining, gels were fixed in $12 \%(\mathrm{w} / \mathrm{v})$ trichloroacetic acid (TCA) solution overnight (Candiano et al. 2004).

\section{Protein identification by ESI-LC-MS analysis}

Stained bands were excised from 1D gels, cut into small pieces, washed once with $200 \mu 1$ of distilled water for 15 minutes and $200 \mu 1$ of $50 \%$ methanol, and dehydrated in $200 \mu 1$ of pure acetonitrile for $20 \mathrm{~min}$. In-gel digestion of proteins with trypsin was performed at $58^{\circ} \mathrm{C}$ as described by Havlis et al. (2003). The resulting peptides were extracted in two steps with $200 \mu 1$ of $5 \%$ formic acid and $200 \mu 1$ of $50 \%$ acetonitrile with $5 \%$ formic acid (30 min each step). The pooled extracts were concentrated using vacuum concentrator and peptides were dissolved in $5 \mu 1$ of $5 \%$ formic acid for ESI-LC-MS. $4 \mu 1$ of sample was analyzed by ESI-LC-MS (Esquire-3000, Bruker Daltonics, Bremen, Germany). Gel eluted peptides were injected into the Liquid Chromatography columns and the corresponding peptides were passed through a high-voltage electric path for ionization in the Mass Spectrometer, ESI-LC-MS (Electro Spray Ionization-Liquid ChromatographMass Spectrometer; Esquire-3000, Bruker Daltonics, Bremen, Germany) for mass spectrometric analysis. MS/MS spectra obtained from the ESI-MS detector were further processed by the Bruker Daltonics Data Analysis software (Interactive data processing, esquire series) and exported to the protein database and search engine Mascot (version 2.0, Matrix Science, http://www.matrixscience.com/search_form_select.html) in Mascot Generic Format (MGF). Searches were performed first against a mass spectrometry data base (MSDB) (ftp://ftp.ncbi. nih.gov/repository/MSDB/msdb.nam). In addition, an own database for Mascot analysis was created $\left(19^{\text {th }}\right.$ May 2005) with sequences from SNAP predictions and annotated protein sequences from the C. cinerea genome (Jason Stajich, Duke University, unpublished, http://genome.semo.edu/cgi-bin/gbrowse/coprinus) combined with the SwissProt database, the NCBI database, the annotated Phanerochaete chrysosporium proteins, and 17 laccase sequences of $C$. cinerea annotated by S. Kilaru (unpublished). All cysteine residues were searched as reduced and methionine residues in the oxidized form. Mascot parameters were set to use monoisotopic masses with tolerance of 1.5 for precursor ions and 0.5 for fragment ions. 


\subsection{Result and discussion}

\subsubsection{Stability test of supernatant activity}

Supernatant laccase was purified from $100 \mathrm{ml}$ 2,5-xylidine induced standing cultures of T. versicolor grown for 14 days at $25^{\circ} \mathrm{C}$. The laccase activity within the supernatant at this point was $3.62 \pm 19.8 \mathrm{U} / \mathrm{ml}$ laccase activity. First, laccase stability was tested in two buffers. $20 \mathrm{mM}$ potassium phosphate buffer pH 6.4 almost retained complete enzyme activity after three days of incubation at $0^{\circ} \mathrm{C}, 4^{\circ} \mathrm{C}$ and $24^{\circ} \mathrm{C}$ (Fig. 1A). In $20 \mathrm{mM}$ of sodium acetate buffer $\mathrm{pH} 5.6$, approximately $15 \%$ of laccase activity was lost at all three temperatures $\left(0^{\circ} \mathrm{C}, 4^{\circ} \mathrm{C}\right.$ and $\left.24^{\circ} \mathrm{C}\right)$ after one day of incubation. However, over $90 \%$ of the initial laccase activity was lost at room temperature $\left(24^{\circ} \mathrm{C}\right)$ after two days of incubation (Fig. 1B). Therefore, all of the enzyme purification steps were performed by keeping the sample on ice in $20 \mathrm{mM}$ potassium phosphate buffer, $\mathrm{pH} 6.4$.
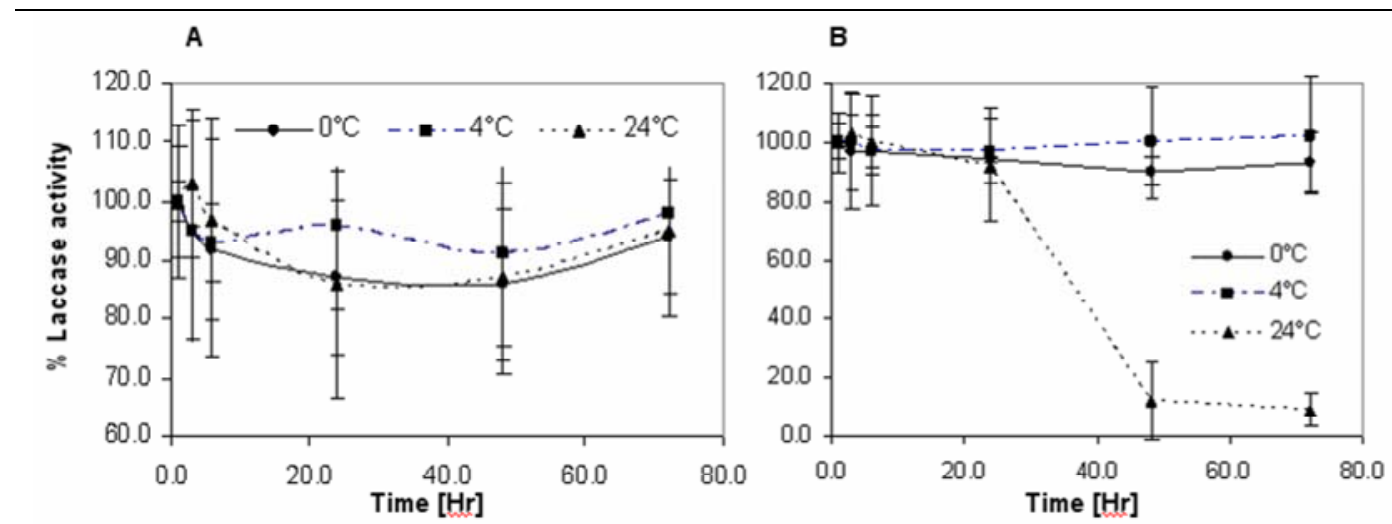

Fig. 1. T. versicolor supernatant laccase stability from a 14 days-old 2,5-xylidine-induced $100 \mathrm{ml}$ BSM media standing culture grown at $25^{\circ} \mathrm{C}$ in $20 \mathrm{mM}$ potassium potassium phosphate buffer $\mathrm{pH} 6.4$ at $0^{\circ} \mathrm{C}$, $4^{\circ} \mathrm{C}$ and $24^{\circ} \mathrm{C}$ (A) and in $20 \mathrm{mM}$ sodium acetate buffer $\mathrm{pH} 5.6$ at $0^{\circ} \mathrm{C}, 4^{\circ} \mathrm{C}$ and $24^{\circ} \mathrm{C} \mathrm{(B).} 200 \mu 1$ of sample was added to $800 \mu \mathrm{l}$ of respective buffers. After incubation, $20 \mu \mathrm{l}$ of solution was tested for laccase activity with $20 \mu \mathrm{l}$ of $50 \mathrm{mM}$ ABTS.

The supernatant $\mathrm{pH}$ was adjusted to 6.4 using $1 \mathrm{M}$ potassium phosphate buffer to get a final concentration of $20 \mathrm{mM}$. The supernatant laccase was purified by ion-exchange chromatography (Table 1). The culture liquid was concentrated on a preparative DEAESepharose (46-165 $\mu \mathrm{m}$ bead size) to separate the enzymes from the culture supernatants on the basis of differences in their net surface charge (http://www.chromatography.amershambiosciences.com/). This yielded fractions with 
high laccase activity (Table 1). Also on the basis of differences in net surface charge but at high resolution, subsequent purification via a Mono-Q column (10 $\mu \mathrm{m}$ bead size) further separated the laccase from other proteins (Fig. 2). Purification via the Mono-Q column yielded a light blue colored laccase solution that had a specific laccase activity of 4482.7 U/mg protein (from fraction C12 obtained after separation of proteins by Mono-Q column) and presented $2.4 \%$ of the total laccase activity from the original culture supernatant.

Table 1. Purification steps for supernatant laccase from 2,5-xylidine-induced culture of $T$. versicolor.

\begin{tabular}{|c|c|c|c|c|c|}
\hline Purification steps & $\begin{array}{c}\text { Total } \\
\text { vol. }[\mathrm{ml}]\end{array}$ & $\begin{array}{c}\text { Total } \\
\text { laccase }[\mathbf{U}]\end{array}$ & $\begin{array}{c}\text { Total } \\
\text { protein [mg] }\end{array}$ & $\begin{array}{c}\text { Specific activity } \\
{\left[\mathrm{U} \mathrm{mg}^{-1}\right]}\end{array}$ & $\begin{array}{c}\text { Times } \\
\text { Purified }\end{array}$ \\
\hline Culture liquid & 3000 & 10,796 & 107.9 & 100.1 & 1.00 \\
\hline Filtration & 2990 & 10,372 & 94.8 & 109.4 & 1.02 \\
\hline $\mathrm{pH}$ adjustment & 3050 & 8,523 & 103.2 & 82.6 & 0.82 \\
\hline Centrifugation & 2770 & 7,569 & 88.0 & 86.0 & 0.85 \\
\hline Cross flow filtration & 2750 & 7,013 & 75.4 & 93.0 & 0.92 \\
\hline DEAE-Sepharose & 80 & 4,752 & 22.7 & 209.5 & 2.09 \\
\hline Concentration by ultra-filtration & 5,6 & 4,603 & 20.4 & 225.8 & 2.25 \\
\hline After Mono-Q ${ }^{1}$ & 0.3 & 367 & 0.085 & 4482.7 & 44.82 \\
\hline
\end{tabular}

The denatured laccase from $\mathrm{C} 12$ fraction resulted in a single protein band on the $12 \%$ SDS-PAGE gel (shown in Fig. 3). The molecular weight of the protein was determined as $67.0 \mathrm{kDa}$ by plotting a graph against standard molecular weight marker, indicating it as a monomeric protein (Fig. 3).

Isoelectric focusing of purified laccase however separated the protein into two isoforms. The $\mathrm{pI}$ value of purified laccase was experimentally determined by isoelectric focusing on $5 \%$ polyacrylamide gels with a $\mathrm{pH}$ range of $2.5-6.5$. The laccase activity was 
visualized by in-gel staining with MBTH + DHPPA (chapter 3). Two distinct laccase isoenzymes with pI values of 2.8 and 2.52 were detected (Fig. 4).

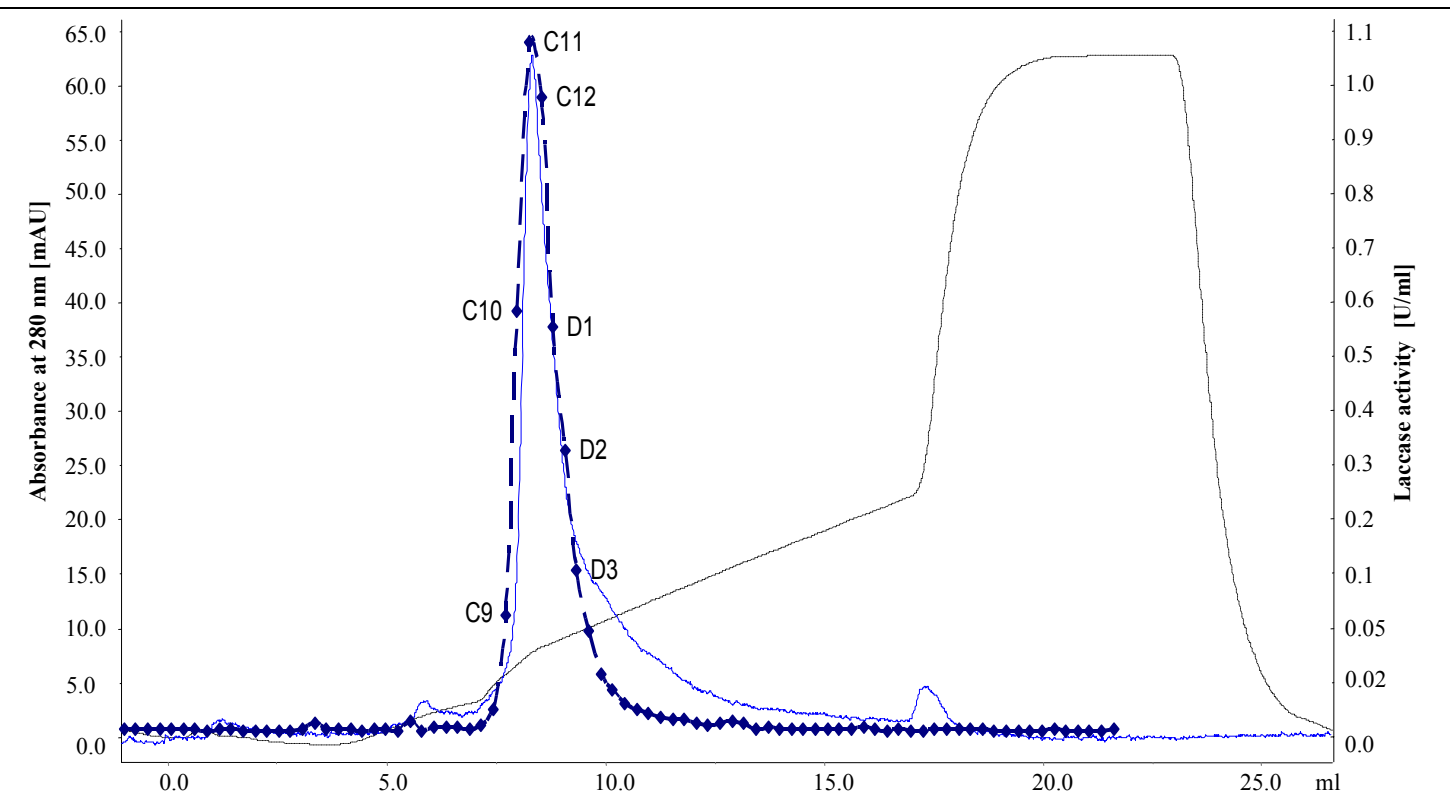

Fig. 2. Partially purified laccase as obtained from prior purification step of culture supernatants from 14 day-old 2,5-xylidine induced culture of $T$. versicolor through DEAE Sepharose columns were loaded onto a Mono-Q column. Adsorbed proteins were eluted by FPLC. Dotted lines indicate $\mathrm{NaCl}$ concentrations used for the elution of proteins, dashed lines the amount of laccase activity detected in the fractions that were collected during salt elution, and continuous lines the absorbance at $280 \mathrm{~nm}$, reflecting the protein concentrations in the eluted fractions. C9-C12 and D1-D3 are the eluted fractions collected after purification of the sample through the Mono-Q column.

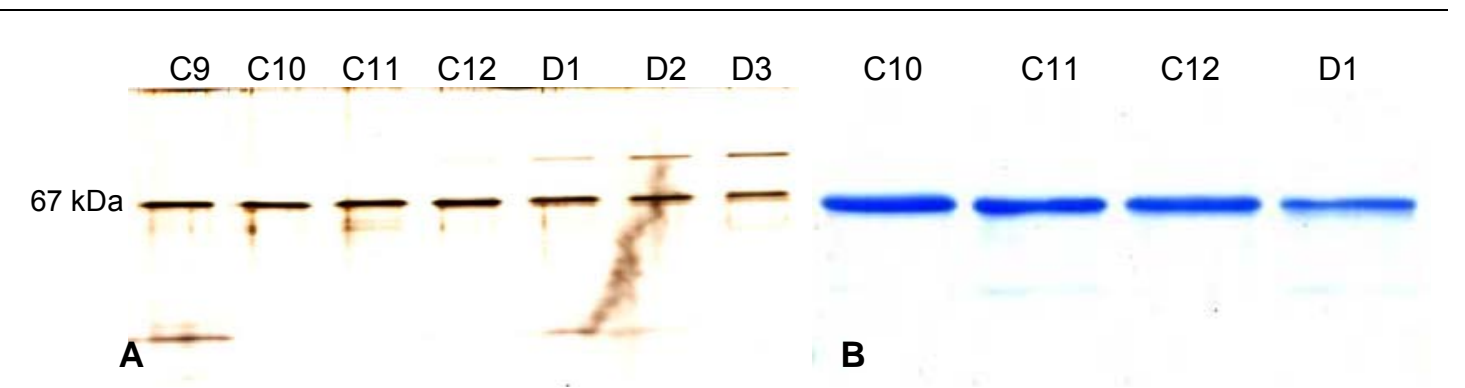

Fig. 3. A $67 \mathrm{kDa}$ single band was obtained from fractions purified from $T$. versicolor culture supernatant after Mono-Q separation. Fractions obtained after elution of proteins that containing laccase activity were separated on $12 \%$ SDS-PAGE gel. A total of $50 \mathrm{ng}$ protein was loaded on a gel (A) from different fractions obtained after Mono-Q separation and silver stained. For some fractions, the amount of protein was increased up to $1 \mu \mathrm{g}(\mathbf{B})$ and also this high amount showed only a single protein band for the C12 fraction when the gel was Coomassie stained. The protein band from C12 was used for ESI-LC-MS identification. 
Fig. 4. pI determination of purified supernatant laccase from a 14 days-old 2,5-xylidine induced BSM culture of $T$. versicolor using isoelectric focusing. pI marker proteins (M), $10 \mathrm{mU}$ of purified laccase stained by Coomassie staining (CL), laccase stained by native staining using MBTH + DHPPA as substrate (NL).

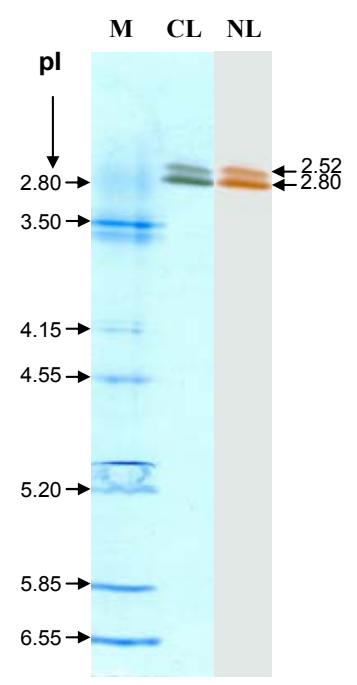

\subsubsection{Identification of the supernatant laccase}

Coomassie stained bands of purified laccase (Fig. 3B) were identified as laccase III from T. versicolor by ESI-LC-MS analysis with a significance score of 240 and coverage of $13 \%$ (Table 2).

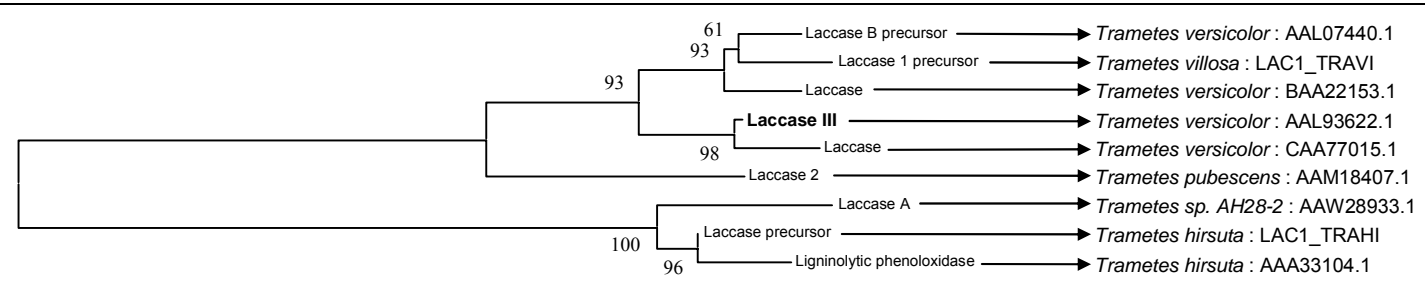

0.01

Fig. 5. Phylogenetic tree of laccases using MEGA Version 2.1 (http://megasoftware.net). The tree was constructed from ClustalW alignments of the core laccase domains. The scale bar indicates the distance equivalent to 0.1 amino acid substitution per site, numbers are bootstrap values. Gene bank accession numbers are: Trametes versicolor AAL07440.1: Trametes villosa LAC1_TRAVI: T. versicolor BAA22153.1: T. versicolor AAL93622.1: T. versicolor CAA77015.1: Trametes pubescens AAM18407.1: Trametes sp. AH28-2 AAW28933.1: Trametes hirsuta LAC1_TRAHI: T. hirsuta AAA33104.1.

Blast results of the peptides obtained from ESI-LC-MS analysis showed 100\% identity with laccase III (Accession no. AAL93622.1) of T. versicolor, 99\% with a laccase (Accession no. CAA77015.1) of another T. versicolor strain, 98\% identity with laccase 1 precursor (Accession no. LAC1_TRAVI) of T. villosa (Yaver et al. 1996) and laccase B precursor (Accession no. AAL07440.1) of T. versicolor, 96\% identity with laccase 2 (Accession no. AAM18407.1) of Trametes pubescens (Galhaup et al. 2002), 91\% 
identity with laccase precursor (Accession no. LAC1_TRAHI) of Trametes hirsutus (Kojima et al. 1990) and 90\% identity with laccase A (Accession no. AAW28933.1) of Trametes sp. AH28-2 (Xiao et al. 2004). All proteins are closely related as shown in the Fig. 5.

Table 2. Identification of a purified supernatant laccase from a 2,5-xylidine induced culture of $T$. versicolor by ESI-LC-MS.

\begin{tabular}{|c|c|c|c|c|c|c|c|}
\hline $\begin{array}{c}\text { Peptides identified by ESI- } \\
\text { LC-MS } \\
\end{array}$ & $\begin{array}{c}\text { Peptide } \\
\text { mass } \mathbf{M}+\mathbf{H} \\
\end{array}$ & $\begin{array}{l}\text { Peptide } \\
\text { score }\end{array}$ & Protein & $\begin{array}{l}\text { Total } \\
\text { score }\end{array}$ & $\begin{array}{l}\text { Cove } \\
\text { rage }\end{array}$ & pI & MW \\
\hline K.LGPAFPLGADATLINGK.G & 1653.91 & 26 & \multirow{4}{*}{$\begin{array}{l}\text { Laccase III, } \\
\text { from } \\
\text { Trametes } \\
\text { versicolor } \\
\text { AAL93622 }\end{array}$} & \multirow[t]{4}{*}{240} & \multirow[t]{4}{*}{$13 \%$} & \multirow[t]{4}{*}{4.8} & \multirow[t]{4}{*}{55724} \\
\hline R.SAGSTVYNYDNPIFR.D & 1702.80 & 38 & & & & & \\
\hline R.SPSTTTADLTVISVTPGKR.Y & 1930.04 & 86 & & & & & \\
\hline R.SPSTTTADLTVISVTPGK.R & 1773.94 & 57 & & & & & \\
\hline
\end{tabular}

\subsubsection{Cell wall associated laccase activity}

Cell wall associated laccase activity was detected at the time of harvest in the 14 day-old mycelia of 2,5-xylidine induced cultures by using ABTS as substrate (Fig. 6).

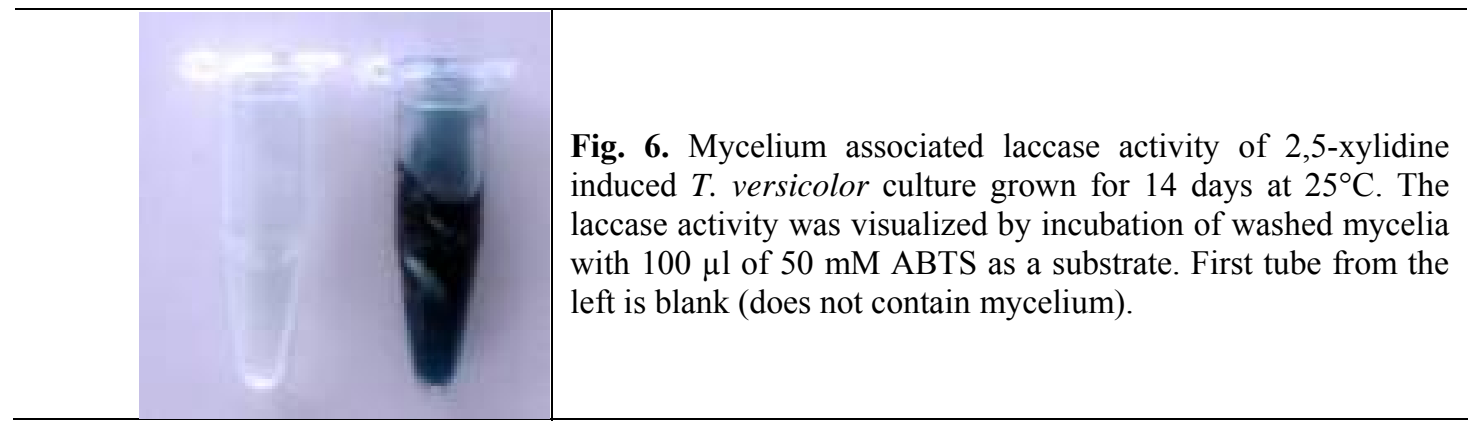

Initial attempts to release the cell wall bound laccase from 2,5-xylidine induced cultures of $T$. versicolor with an objective to purify and characterize the cell wall associated laccase were unsuccessful (however, see chapter 5 for later attempts that were at least partially successful upon standardization of the conditions for the release of laccase from the cell walls). Therefore, in the present study, laccase was characterized in its cell wall bound form for different substrates, temperature optimum, temperature stability and inhibitors. The same parameters were compared as used for the purified laccase obtained from the supernatant of 2,5-xylidine induced cultures of $T$. versicolor. 


\subsubsection{Characterization cell wall and supernatant laccase}

Cell wall bound and purified supernatant laccases were characterized for substrate activity with ABTS, guaiacol, syringaldazine, and DMP in $50 \mathrm{mM}, 50 \mathrm{mM}, 0.05 \%$ and $0.3 \%$ concentration respectively in Davies Universal Buffer (DUB) $\mathrm{pH}$ 2.0-10.0. For supernatant and cell wall associated laccase, highest enzyme activity was measured at $\mathrm{pH}$ 4.0 with ABTS.
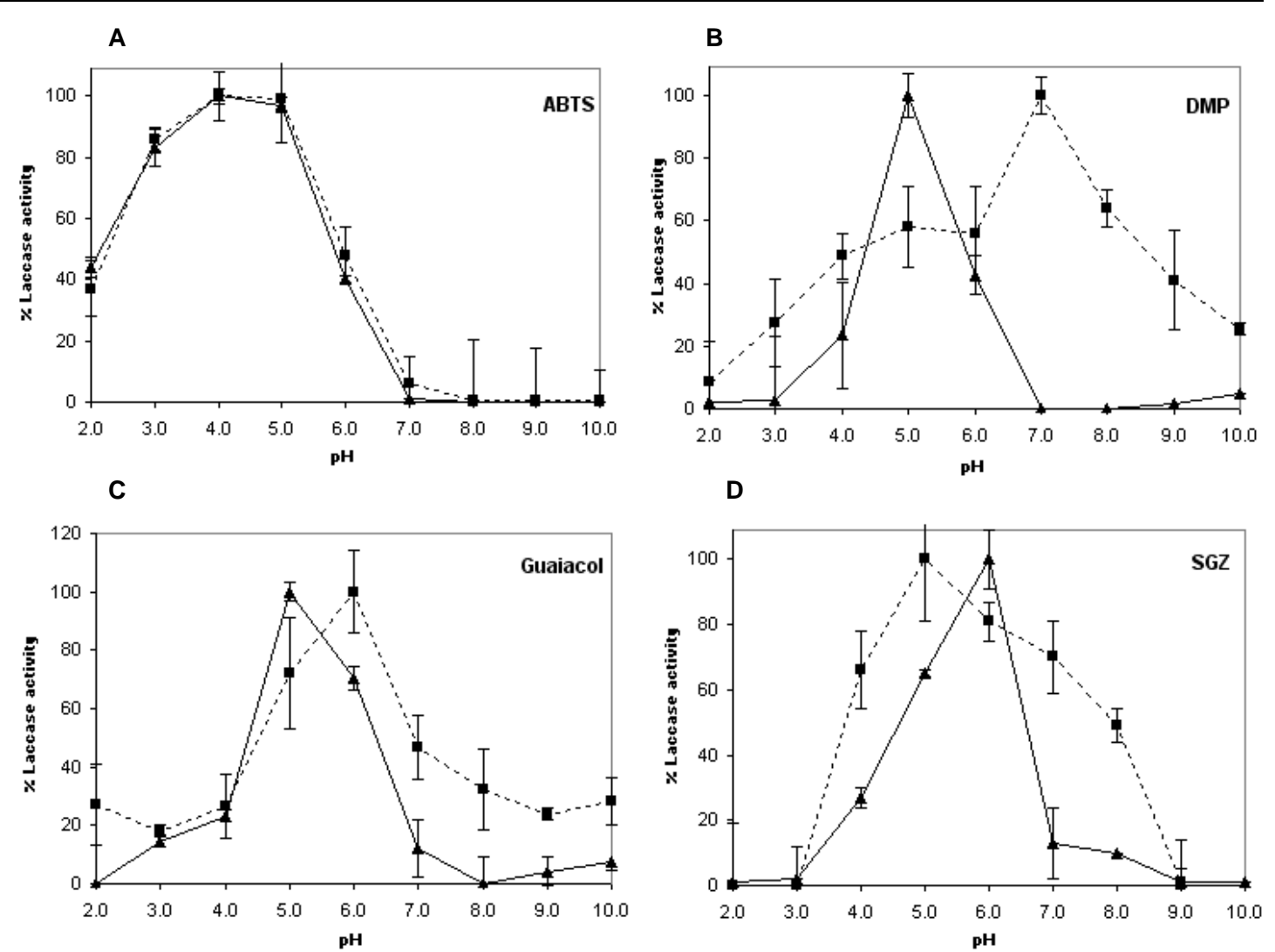

Fig. 7. Comparison of enzymatic activity of 2,5-xylidine induced cell wall bound and purified supernatant laccase with various substrates ABTS [2,2'-Azino-bis(3-ethylbenzothiazoline-6-sulfonic acid)] (A), DMP (2,6-dimethoxyphenol) (B), guiacol (C) and SGZ (syringaldazine) (D). Maximum laccase activities of $28.1,1.6,1.6,0.7 \mathrm{mU} / \mathrm{mg}$ dry weights of cell wall and 75.9, 19.5, 28.9, $13.0 \mathrm{mU} / \mathrm{ml}$ of supernatant for ABTS, DMP, guiacol and SGZ respectively were set as $100 \%$ and the activities at other $\mathrm{pHs}$ were plotted with $100 \%$ as the reference.

Using guaiacol as laccase substrate $\mathrm{pH}$ optima for the cell wall associated laccase was $\mathrm{pH}$ 6.0 and for supernatant laccase $\mathrm{pH}$ 5.0. With syringaldazine the $\mathrm{pH}$ optima were $\mathrm{pH} 5.0$ and $\mathrm{pH} 6.0$ for the cell wall associated and purified supernatant laccases, respectively. 
With DMP the optimum $\mathrm{pH}$ for the cell wall bound laccase was $\mathrm{pH} 7.0$ and for supernatant laccase pH 5.0 (Fig. 7).

The purified laccase was incubated at different temperatures ranging from $10^{\circ} \mathrm{C}$ to $70^{\circ} \mathrm{C}$ to determine optimum temperature for highest enzyme activity. The temperature optimum for the cell wall bound laccase was $40^{\circ} \mathrm{C}$, while that for the supernatant laccase was $50^{\circ} \mathrm{C}$.

The cell wall bound and supernatant laccase stability was tested at $50^{\circ} \mathrm{C}$ after several time intervals. $50 \%$ of the supernatant laccase activity was lost within six hours of incubation. However, the cell wall associated laccase lost about $25 \%$ of the enzyme activity after six hours of incubation (Fig. 8).
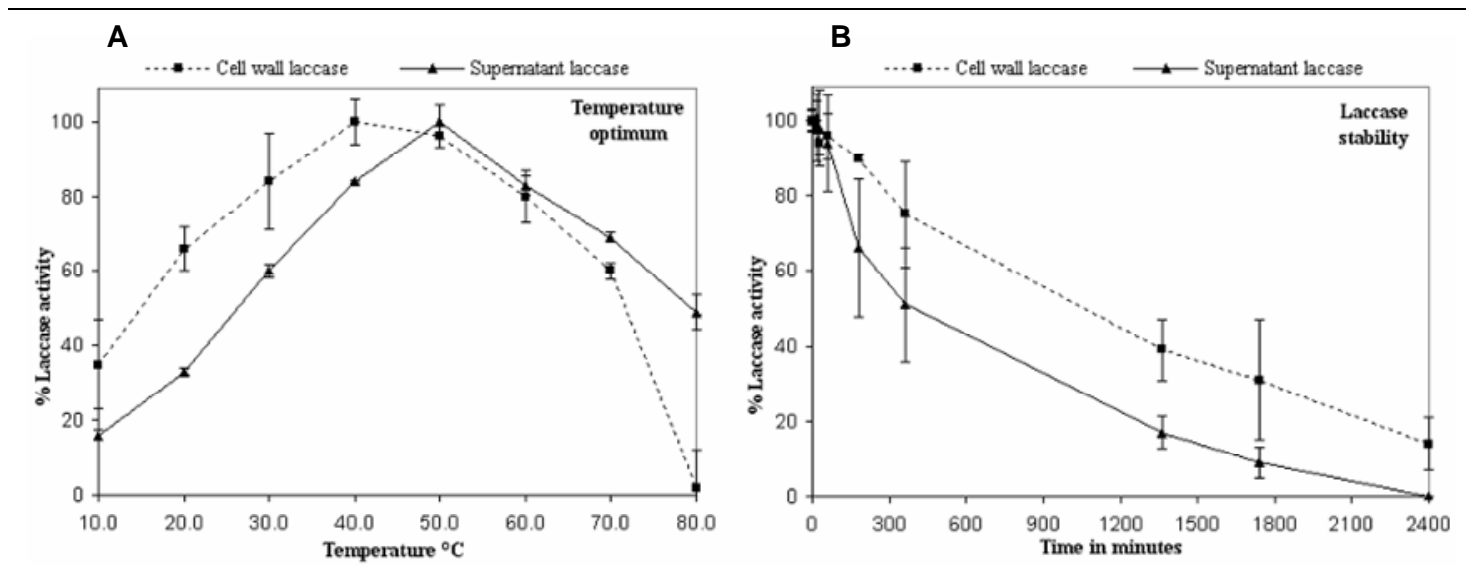

Fig. 8. Comparison of laccase activity for 2,5-xylidine induced purified supernatant laccase to the cell wall bound laccase at different temperatures (A) and temperature stability of supernatant and cell wall bound laccase at $50^{\circ} \mathrm{C}(\mathbf{B})$.

The effect of inhibitors was tested on the cell wall associated and on the purified supernatant laccase (Table 3). In general, the supernatant laccase was more susceptible to inhibition than the cell wall bound form. $0.01 \mathrm{mM} \mathrm{NaN}_{3}$ inhibited up to $88 \%$ of the supernatant laccase activity, while only $2 \%$ of activity was lost in the cell wall bound form. $1.0 \mathrm{mM} \mathrm{NaN}_{3}$ showed $100 \%$ inhibition of supernatant laccase activity, while $94 \%$ of cell wall bound laccase activity was inhibited. Inhibition by $\mathrm{NaF}$ was more effective at higher concentration; $10 \mathrm{mM}$ of $\mathrm{NaF}$ killed $86 \%$ of the cell wall associated laccase activity while the same concentration of inhibitor killed $99 \%$ of supernatant laccase activity after half an hour. $10 \mathrm{mM}$ EDTA could inhibit $45 \%$ of the supernatant laccase 
activity and showed nearly no inhibitory effect on the cell wall associated laccase (Table $3)$. A higher concentration of EDTA (20 mM) was found to inhibit only $13 \%$ of the cell wall associated laccase activity and $96 \%$ of purified supernatant laccase activity (Table 3). In conclusion from these data, $\mathrm{NaN}_{3}$ was the best inhibitor for complete inhibition of laccase activity in the supernatant and partial inhibition of the cell wall laccase activity at the low concentration of $1.0 \mathrm{mM}$.

Table 3. Laccase inhibitors and their concentration used for inhibiting purified supernatant and cell wall bound laccase. With exception of the treatments with urea*, remaining activities were determined after $30 \mathrm{~min}$ of incubation. Per inhibitor concentration, three independent reactions were performed and used to calculate average values with standard deviations.

\begin{tabular}{lccc}
\hline $\begin{array}{l}\text { Name of } \\
\text { inhibitor }\end{array}$ & $\begin{array}{c}\text { Inhibitor } \\
\text { conc. }(\mathbf{m M})\end{array}$ & $\begin{array}{c}\text { Remaining supernatant } \\
\text { laccase activity }\end{array}$ & $\begin{array}{c}\text { Remaining cell wall } \\
\text { laccase activity }\end{array}$ \\
\hline $\mathbf{N a N}_{3}$ & 0.01 & $12.0 \pm 7.0 \%$ & $98.0 \pm 7.0 \%$ \\
& 0.1 & $2.0 \pm 17.0 \%$ & $59.0 \pm 7.0 \%$ \\
\hline NaF & 1.0 & $0.0 \pm 0.0 \%$ & $6.0 \pm 14.0 \%$ \\
& 0.1 & $55.0 \pm 5.0 \%$ & $95.0 \pm 12.0 \%$ \\
& 1.0 & $10.0 \pm 11.0 \%$ & $42.0 \pm 6.0 \%$ \\
\hline EDTA & 10.0 & $1.0 \pm 18.0 \%$ & $14.0 \pm 14.0 \%$ \\
\hline Urea* & 10.0 & $55.0 \pm 14.0 \%$ & $99.0 \pm 5.0 \%$ \\
& 20.0 & $4.0 \pm 17.0 \%$ & $87.0 \pm 4.0 \%$ \\
& 1000 & $82.4 \%$ & n.d \\
& 2000 & $69.1 \%$ & n.d. \\
& 3000 & $69.8 \%$ & n.d. \\
& 4000 & $65.2 \%$ & n.d. \\
& 5000 & $49.0 \%$ & n.d. \\
\hline
\end{tabular}

* For analysis of the effect of urea on supernatant laccase activity, single measurements were done. The reaction was carried out for $26 \mathrm{hrs}$ and measured after this time point. n.d. = not determined.

Further to the above inhibitors, effects of urea was tested on purified supernatant laccase by using $1000 \mathrm{mU}$ laccase in $1.0 \mathrm{ml} 100 \mathrm{mM}$ sodium acetate buffer, $\mathrm{pH} 5.8$. This was necessary because urea is normally used in the loading buffer for 2D-gel electrophoresis (see methods section in Chapter 3) and this should not lead to improper results in later native staining. In the experiment performed, purified supernatant laccase from a 2,5- 
xylidine induced culture of $\mathrm{T}$. versicolor lost $51 \%$ of enzyme activity after incubation with $5 \mathrm{M}$ urea within 26 hours of incubation at $24^{\circ} \mathrm{C}$ (Table 3, Fig. 8). This inhibition effect was not followed up further with the cell walls since urea did not demonstrate much inhibition with respect to a physiological range of urea concentrations. For 2Delectrophoresis however, it was expected that the temporary usage of urea in the loading buffer ( $8 \mathrm{M}$ urea; see methods section in Chapter 3 ) would still allow the detection of laccase activity, albeit at a possibly reduced level (see for a positive example of laccase detection in 2D-gelelectrophoresis see e.g. Fig. 6B in Chapter 3 - note that there was some reduction in activity as compared to $1 \mathrm{D}$-gelelectrophoresis seen in Fig. 6A in Chapter 3 where urea was not applied in the loading buffer).

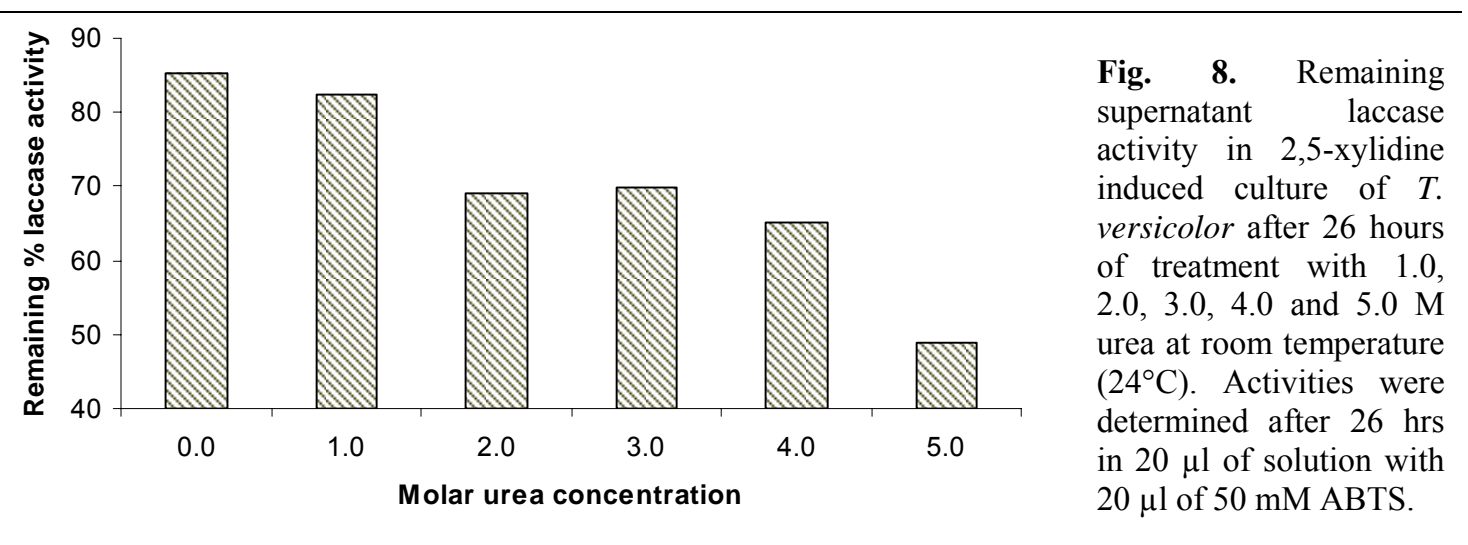

\subsubsection{Conclusion}

Purified supernatant laccase from the 2,5-xylidine induced cultures of $T$. versicolor was identified by ESI-LC-MS analysis of peptides as laccase III described earlier by (Morohoshi et al. 1987). At the current stage, the identity of the cell wall associated lacasse is unknown, i.e. whether the enzyme has been found before in unbound form in culture supernatants or whether this enzyme is a new protein. The cell wall associated and the supernatant laccases showed differences in their substrate activities for three out of four tested substrates. Additionally, the cell wall associated laccase showed a higher temperature stability and it was more resistant to inhibitors as compared to the purified supernatant laccase. 
Since some characteristics like substrate activity with ABTS were similar for both cell wall and supernatant laccases, while the other characteristics differ between the two, the following possibilities exist and can currently not be distinguished: 1) The laccase present in the cell wall and the supernatant present two distinct enzymes or 2) the same laccase exhibit different characteristics when associated to the cell wall or when present in the supernatant. This had to be further tested by ESI-LC-MS analysis of the bound enzyme after release from the cell walls (see chapter 5).

\subsection{References}

Antorini M., Herpoel-Gimbert I., Choinowski T., Sigoillot J.C., Asther M., Winterhalter K., and Piontek K. (2002). Purification, crystallisation and X-ray diffraction study of fully functional laccases from two ligninolytic fungi. Biochimica et Biophysica Acta-Protein Structure and Molecular Enzymology 1594:109-114.

Baldrian P. (2005). Fungal laccase - occurrence and properties. FEMS Microbiology Reviews 2:1-28

Bertrand T., Jolivalt C., Briozzo P., Caminade E., Joly N., Madzak C., and Mougin C. (2002a). Crystal structure of a four-copper laccase complexed with an arylamine: Insights into substrate recognition and correlation with kinetics. Biochemistry 41:7325-7333.

Bertrand T., Jolivalt C., Caminade E., Joly N., Mougin C., and Briozzo P. (2002b). Purification and preliminary crystallographic study of Trametes versicolor laccase in its native form. Acta Crystallographica Section D-Biological Crystallography 58:319-321.

Blum H., Beier H., and Gross H.J. (1987). Improved silver staining of plant proteins, RNA and DNA in polyacrylamide gels. Electrophoresis 8:93-99.

Candiano G., Bruschi M., Musante L., Santucci L., Ghiggeri G.M., Carnemolla B., Orecchia P., Zardi L., and Righetti P.G. (2004). Blue silver: A very sensitive colloidal Coomassie G-250 staining for proteome analysis. Electrophoresis 25:1327-1333.

Daniel G. (1994). Use of electron microscopy for aiding our understanding of wood biodegradation. FEMS Microbiology Reviews 13:199-233.

Dicko M.H., Hilhorst R., Gruppen H., Laane C., van Berkel W.J.H., and Voragen A.G.J. (2002). Zymography of monophenolase and o-diphenolase activities of polyphenol oxidase. Analytical Biochemistry 306:336-339.

Eggert C., Temp U., Dean J.F.D., and Eriksson K.E.L. (1996). A fungal metabolite mediates degradation of non-phenolic lignin structures and synthetic lignin by laccase. FEBS Letters 391:144-148. 
Eggert C., Temp U., and Eriksson K.E.L. (1997). Laccase is essential for lignin degradation by the white rot fungus Pycnoporus cinnabarinus. FEBS Letters 407:89-92.

Galhaup C., Goller S., Peterbauer C.K., Strauss J., and Haltrich D. (2002). Characterization of the major laccase isoenzyme from Trametes pubescens and regulation of its synthesis by metal ions. Microbiology-Sgm 148:2159-2169.

Gavnholt B., and Larsen K. (2002). Molecular biology of plant laccases in relation to lignin formation. Physiologica Plantarum 116 (3): 273-280.

Havlis J., Thomas H., Sebela M., and Shevchenko A. (2003). Fast-response proteomics by accelerated in-gel digestion of proteins. Analytical Chemistry 75:1300-1306.

Hüttermann A., and Volger C. (1973). Induction of aryl beta glucosidase in Fomes annosus by cellobiose. Archiv fur Mikrobiologie 93:195-204.

Kilaru S. (2006). Identification of fungal multi-copper oxidase gene families: Overexpression and characterization of Coprinopsis cinerea laccases for applications in biotechnology, $\mathrm{PhD}$ thesis, University of Göttingen, Germany.

Iimura Y., Takenouchi K., Nakamura M., Kawai S., Katayama Y., and Morohoshi N. (1992). Cloning and sequence analysis of laccase genes and its use for a expression vector in Coriolus versicolor. Journal of Cellular Biochemistry 427-431.

Jones C.L., and Lonergan G.T. (1999). Histochemical detection of laccase in Pycnoporus cinnabarinus using microwave-enhanced colloidal gold microcrystallization. Biotechnology Techniques 13:871-875.

Kojima Y., Tsukuda Y., Kawai Y., Tsukamoto A., Sugiura J., Sakaino M., and Kita Y. (1990). Cloning sequence analysis and expression of ligninolytic phenoloxidase genes of the white rot basidiomycete Coriolus hirsutus. Journal of Biological Chemistry 265:15224-15230.

Kües U., and Liu Y. (2000). Fruitbody production in basidiomycetes. Applied and Environmental Microbiology 54 (2):141-153.

Laemmli U.K. (1970). Cleavage of structural proteins during assembly of head of bacteriophageT4. Nature 227:680-685.

Langfelder K., Streibel M., Jahn B., Haase G., and Brakhage A.A. (2003). Biosynthesis of fungal melanins and their importance for human pathogenic fungi. Fungal Genetics and Biology. 38: $143-158$.

Leonowicz A., Matuszewska A., Luterek J., Ziegenhagen D., Wojtas-Wasilewska M., Cho N.S., Hofrichter M., and Rogalski J. (1999). Biodegradation of lignin by white rot fungi. Fungal Genetics and Biology 27:175-185. 
Majcherczyk A., Johannes C., and Hüttermann A. (1998). Oxidation of polycyclic aromatic hydrocarbons (PAH) by laccase of Trametes versicolor. Enzyme and Microbial Technology 22:335-341.

Matsumura E., Yamamoto E., Numata A., Kawano T., Shin T., and Murao S. (1986). Structures of the laccase catalyzed oxidation products of hydroxy benzoic acids in the presence of ABTS (2,2'-Azino-Di-(3-Ethylbenzothiazoline-6-Sulfonic Acid)). Agricultural and Biological Chemistry 50:1355-1357.

Mikuni J., and Morohoshi N. (1997). Cloning and sequencing of a second laccase gene from the white-rot fungus Coriolus versicolor. FEMS Microbiology Letters 155:79-84.

Morohoshi N., Wariishi H., Muraiso C., Nagai T., and Haraguchi T. (1987). Degradation of lignin by the extracellular enzymes of Coriolus versicolor IV. Properties of three laccase fractions fractionated from the extracellular enzymes. Mokuzai Gakkaishi 33:218-225.

Ruel K.C., and Joseleau J.P. (2003). Development of immunomicroscopic methods for bioremediation. In: The utilization of bioremediation to reduce soil contamination: Problems and solutions (Sasek et al. eds). Kluywer Academic Publishers, Dordrecht, pp. 187-197

Sakurai T. (1992). Anaerobic Reactions of Rhus vernicifera laccase and its type-2 copper depleted derivatives with hexacyanoferrate(II). Biochemical Journal 284:681-685.

Sealey J., and Ragauskas A.J. (1998). Residual lignin studies of laccase delignified kraft pulps. Enzyme and Microbial Technology 23:422-426.

Slomczynski D., Nakas J.P., and Tanenbaum S.W. (1995). Production and characterization of laccase from Botrytis cinerea-61-34. Applied and Environmental Microbiology 61:907-912.

Smith M., Thurston C.F., and Wood D.A. (1997). Fungal laccases: Role in delignification and possible industrial application. In: Multi-copper oxidases (Messerschmidt A. ed.), World Scientific Publishing Co. Pte. Ltd., Singapore, pp. 201-224.

Solomon E.I., Sundaram U.M., and Machonkin T.E. (1996). Multicopper oxidases and oxygenases. Chemical Reviews 96:2563-2605.

Srebotnik E., and Messner K. (1998). Determination of the accessibility of lignocellulosic substrates to enzymatic degradation by immunoelectron microscopy. In: Institute of Physics Conference Series No. 93/3 Dickinson H.G., Goodhew P.J. (eds) EUREM 88. Bristol, Philadelphia:, pp 107108

Stauff J., and Jaenicke R. (1994). Physikalische Chemie der Lösungen. In: Biochemisches Taschenbuch-II (Rauen H.M ed.), $2^{\text {nd }}$ Edition, Springer-Verlag, Berlin Heidelberg, pp. 37121.

Wariishi H., Valli K., and Gold M.H. (1992). Manganese(II) oxidation by manganese peroxidase from the basidiomycete Phanerochaete chrysosporium - kinetic mechanism and role of chelators. Journal of Biological Chemistry 267:23688-23695. 
Xiao Y.Z., Tu X.M., Wang J., Zhang M., Cheng Q., Zeng W.Y., and Shi Y.Y. (2003). Purification, molecular characterization and reactivity with aromatic compounds of a laccase from basidiomycete Trametes sp strain AH28-2. Applied Microbiology and Biotechnology 60:700-707.

Xiao Y.Z., Chen Q., Hang J., Shi Y.Y., Xiao Y.Z., Wu J., Hong Y.Z., and Wang Y.P. (2004). Selective induction, purification and characterization of a laccase isozyme from the basidiomycete Trametes sp AH28-2. Mycologia 96:26-35.

Yaver D.S., Xu F., Golightly E.J., Brown K.M., Brown S.H., Rey M.W., Schneider P., Halkier T., Mondorf K., and Dalboge H. (1996). Purification, characterization, molecular cloning, and expression of two laccase genes from the white rot basidiomycete Trametes villosa. Applied and Environmental Microbiology 62:834-841.

Yoshida H. (1883). Chemistry of lacquer (urushi). Part I. J Chem Soc 43:472-486.

Zhu X.D., Gibbons J., Garcia-Rivera J., Casadevall A., and Williamson P.R. (2001). Laccase of Cryptococcus neoformans is a cell wall-associated virulence factor. Infection and Immunity 69:5589-5596.

Zhu X.D., and Williamson P.R. (2003). A CLC-type chloride channel gene is required for laccase activity and virulence in Cryptococcus neoformans. Mol. Microbiol. 50:1271-1281. 


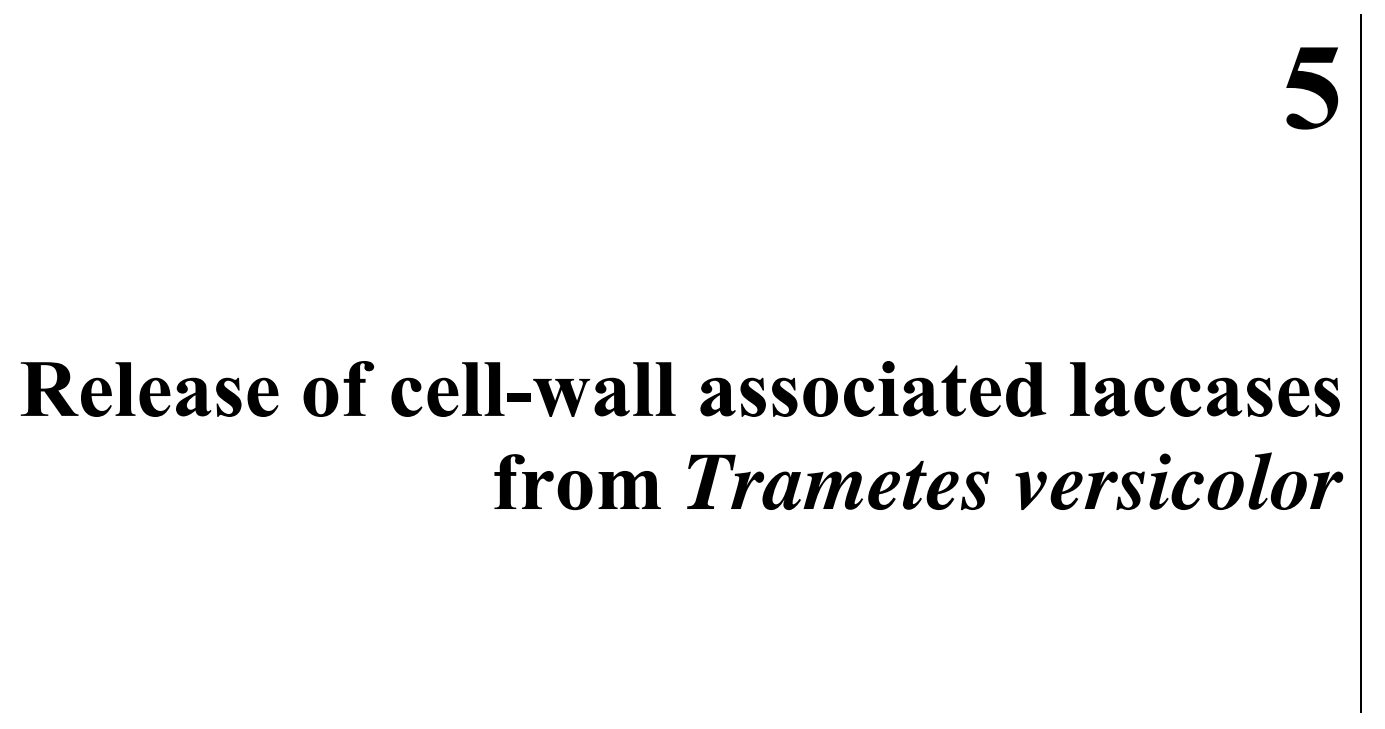





\title{
5. Release of cell-wall associated laccases from $T$. versicolor
}

\begin{abstract}
5.1 Abstract
A number of proteins and enzymes are associated to the fungal cell wall. They can either be entrapped inside the cell wall or bound by non-covalent or covalent interactions. In the previous chapter, I detected and characterized cell wall-associated laccase activity in $T$. versicolor. In this study, several methods were tried to release the cell wall associated laccase from $T$. versicolor. Sequential extraction of the cell wall samples with hydrolytic enzymes cellulase, chitinase and Trichoderma lysate under shaking the samples on a horizontal shaker lead to the release of the laccase. Additionally, reducing agents such as tributylphosphine (TBP) were found to somewhat increase the amount of released laccase in the buffer after incubation, when used together with the hydrolytic enzymes. Identification of the released laccase was done by ESI-LC-MS. The released enzyme was found to be laccase III and thus to be identical to the formerly identified enzyme from the culture supernatant of the same strain. As a second secreted protein acting in wood degradation, pyranose oxidase producing $\mathrm{H}_{2} \mathrm{O}_{2}$ was found in addition been released from the cell walls by ESI-LC-MS analysis of a phenol-oxidase active band from a protein gel.
\end{abstract}

\subsection{Introduction}

A fungal cell is surrounded by a highly elastic and robust structure called the cell wall. The most apparent function of the cell wall is protecting the cell against osmotic, chemical and biological injury (Smith et al. 2000). In the past, most of the studies involved in understanding the fungal cell wall were performed on Saccharomyces cerevisiae, Candida albicans and Aspergillus species but the studies elucidating the cell wall of basidiomycetes are still in their early stages, with only a few papers describing the cell wall of basidiomycetes like of the mycelium of Schizophyllum commune (Wessels et al. 1979), of the yeast and mycelial form of Ustilago maydis (Ruiz-Herrera et al. 1996) and the yeast form of Cryptococcus neoformans (Cherniak et al. 1993; Vaishnav et al. 1998).

Abbreviations: CWPs (cell wall associated proteins), PMSF (phenylmethylsulfonylflouoride), EDTA (ethylenediaminetetraacetic acid), DTT (dithiothreitol), TBP (tributylphosphine), ABTS [2,2'-azino-bis(3ethylenbenzothiazoline-6-sulfonic-acid)], TMA (N,N,N',N'-tetramethyl-1,4-phenylenediammonium dichloride) 
A large number of proteins and enzymes are known to be associated with the cell wall of ascomycetes and are classified as cell wall associated Proteins (CWPs). These CWPs are highly glycosylated and form the outer layer of the cell wall. The amount of carbohydrate content often amounts to over 90\% of total cell wall dry weight (Ruiz-Herrera 1992; Orlean 1997). Most of the cell wall glycoproteins are considered to be catalytically active (Mrsa et al. 1999). In the basidiomycetes, there are few well characterized structural cell wall proteins such as hydrophobins (Wösten 2001; Walser et al. 2003) and galectins (Walser et al. 2003; 2004; 2005). However, in comparison to ascomycetes much less is known about the proteins and enzymes residing in the cell walls of basidiomycetes. Many cell wall associated enzymes are responsible for basic reactions in the cell wall synthesis (Latgé and Calderone 2006; Sietsma and Wessels 2006) while others may contribute to the breakdown of growth substrates (Tuor et al. 1995).

Using various methods like co-precipitation of gold particles, immuno-gold labeling, and scanning electron microscopy, a number of oxidative enzymes (such as aryl-alcohol oxidase and pyranose oxidase) and hydrolytic enzymes (e.g. cellulases, glucanases, and xylanase) have been shown to be associated with the apical tip, the sub-apical hyphal sheath and the cell wall of higher fungi (Daniel 1994a; Cai et al. 1999). Laccases were entrapped within the exo-polysaccharide shields of Ceriporiopsis subvermispora, Rigidoporus lignosus hyphae and also within the cell walls of Phlebia radiata (Nicole et al. 1992; Ruel et al. 2003). Furthermore, pyranose oxidase, aryl-alcohol oxidase, glucanases, cellulases and xylanase have been detected by gold-immunolabeling in association with the cell wall or the extra-cellular glucan sheath in wood degrading fungi (Barrasa et al. 1998; Cai et al. 1999).

Only a few studies have been conducted so far for releasing the cell wall associated laccase. From human pathogen Cryptococcus neoformans, the cell wall associated laccase activity was retained in the cell wall after sequential extraction with salt, urea and SDS. However, about $40 \%$ of the laccase was released from intact cells or cell wall fractions upon enzymatic treatment with glucanases (Zhu et al. 2001; 2003). From sporocarps of the edible basidiomycete Agaricus bisporus, a total of 19\% of cell wall-associated phenoloxidase activity was liberated by salt $(\mathrm{NaCl})$ extraction steps while detergent (digito- 
nin) treatment could release up to $48 \%$ of phenoloxidase activity (Sassoon and Mooibroek 2001).

In this work, I tested various chemical and enzymatic methods to release the cell wall associated enzymes, specifically laccase from one of the higher basidiomycetes $T$. versicolor.

\subsection{Materials and methods}

\section{Fungal cultures and harvesting}

Trametes versicolor strain number 6 from the collection of the Institute of Forest Botany, Georg August Universität, Göttingen, was cultivated on basidiomycetes-medium (BSM, Hüttermann and Volger, 1973) with 1.5\% agar. Starter liquid cultures were prepared by inoculation of $100 \mathrm{ml} \mathrm{BSM}$ liquid medium in $500 \mathrm{ml}$ conical flasks with three agar pieces $\left(1 \mathrm{~cm}\right.$ in diameter) of the stock culture and cultivated stationary at $25^{\circ} \mathrm{C}$ in the dark. Mycelium of 14 days-old liquid cultures were gently disrupted using an UltraTurrax T25 (rod diameter $10 \mathrm{~mm}$; Janke \& Kunkel, IKA-Labortechnik, Germany) at 9,000 rpm for 1 minute under sterile conditions. Each $4 \mathrm{ml}$ of mycelium suspension were used to inoculate new $100 \mathrm{ml}$ BSM liquid cultures. Standing cultures of T. versicolor were induced after seven days of incubation with $100 \mu 10.5 \mathrm{M}$ 2,5-xylidine and incubated further for seven more days stationary at $25^{\circ} \mathrm{C}$ in the dark. The culture supernatants were harvested by vacuum filtration using filter paper (595 Round filter, $\varnothing$ $90 \mathrm{~mm}$, Schleicher \& Micro Science GmbH, Germany). The culture filtrate was kept on ice and the mycelia were washed twice with $2-5 \mathrm{ml}$ of distilled water.

\section{Cell wall sample preparation}

About $2 \mathrm{~g}$ of freshly collected mycelium form 2,5-xylidine-induced cultures of $T$. versicolor were transferred in a $200 \mathrm{ml}$ Schott glass bottle containing $20 \mathrm{ml}$ of sodium acetate buffer (100 mM, pH 5.8). $1 \mathrm{mM}$ of PMSF (phenylmethanesulfonyl fluoride; Sigma, Germany) was added to the buffer to avoid any protease activity and all steps 
were performed on ice. The sample was homogenized using an Ultra-Turrax T25 (rod diameter $10 \mathrm{~mm}$; Janke \& Kunkel, IKA-Labortechnik, Germany) at 24,000 rpm for 3 minutes. Homogenized samples were re-suspended in $20 \mathrm{ml}$ of sodium acetate buffer (100 mM, pH 5.8) and incubated for $30 \mathrm{~min}$ to remove supernatant laccase activity. The pellet was collected by centrifugation at $600 \mathrm{~g}$ for $5 \mathrm{~min}$ at $4^{\circ} \mathrm{C}$. The same step was repeated for four more times.

\section{Enzyme activities}

Laccase activity in the liquid culture and also in the cell wall samples was measured by using ABTS [2,2'-azino-bis(3-ethylenbenzothiazoline-6-sulfonic-acid)] as substrate Matsumura et al. (1986). One unit of laccase activity is defined as the amount of laccase that oxidize $1 \mu \mathrm{mol}$ substrate per minute.

Supernatant enzyme activities: The ABTS test was performed as described by Matsumura et al. (1986).

Cell wall bound enzyme activities: Approximately $10.0 \mathrm{mg}$ of wet cell wall samples were incubated in $1.5 \mathrm{ml}$ plastic micro tubes for $30 \mathrm{~min}$ in $900 \mu \mathrm{l}$ Universal Davis buffer (Stauff and Jaenicke 1964) pH 2.0 to 10.0. Thereafter, $100 \mu 1$ of $50 \mathrm{mM} \mathrm{ABTS}$ was added to the plastic micro tubes and gently mixed every five seconds by inverting the tubes. The reaction was stopped by addition of $50 \mu \mathrm{l}$ of $50 \mathrm{mM} \mathrm{NaN}_{3}$. The micro tubes were centrifuged for 10 seconds and change in absorbance was measured at $420 \mathrm{~nm}$. Samples without mycelia were used as control. The remaining sample pellet was dried at $105^{\circ} \mathrm{C}$ for two days and the dry weight of mycelia was measured. Mycelium bound laccase activity was calculated in $\mathrm{U} / \mathrm{mg}$ dry weight.

\section{Native protein sample preparation}

The supernatant obtained from 14 days-old cultures was centrifuged for $20 \mathrm{~min}$ at $3,000 \mathrm{~g}$ and concentrated by ultra-filtration with $3 \mathrm{kDa}$ MWCO polyether sulfone membrane (Vivaspin, Vivascience AG, Hannover Germany) at 3,000 g to obtain at least $20 \mathrm{U} / \mathrm{ml}$ concentration of laccase activity. 


\section{D-PAGE and Staining}

1D-SDS-PAGE electrophoresis was performed using $12 \times 12 \mathrm{~cm}$ discontinuous $12 \%$ acrylamide gels with $0.025 \mathrm{M}$ Tris base, $\mathrm{pH} 8.3$ as electrode buffer (Laemmli 1970). Protein samples were mixed in sample buffer (0.06 M Tris-Cl, pH 6.8, 10\% glycerol, $0,025 \%$ bromphenol blue). $20 \mu 1$ samples with $1 \mu \mathrm{g} / \mu \mathrm{l}$ protein were loaded and run at 10 $15^{\circ} \mathrm{C}$ at a constant current of $30 \mathrm{~mA}$. For silver staining, the gels were fixed in $30 \%$ methanol with $12 \%$ acetic acid and $0.05 \%$ formaldehyde overnight and stained as described by Blum et al (1987). For colloidal Coomassie blue staining gels were fixed in $12 \%(\mathrm{w} / \mathrm{v})$ trichloroacetic acid (TCA) solution overnight (Candiano et al. 2004). For native staining, gels were transferred to $100 \mathrm{mM}$ sodium acetate buffer $\mathrm{pH} 5.0$ for 30 min. The buffer was changed by $100 \mathrm{ml}$ of fresh buffer and $8.4 \mathrm{mM}$ TMA $+9.7 \mathrm{mM} \alpha-$ naphthol were added to visualize laccase activity. Stained gels were scanned at $300 \mathrm{dpi}$ resolution (Microtek, TMA 1600, Germany).

\section{Release of cell wall associated laccase}

Cell wall associated laccases were released by using various hydrolytic enzymes [Trichoderma lysate (Serva, Germany, Product No. 16420.01), cellulase (Merck, Product No. 102321), chitinase (Sigma, Germany, Product No. C-6137), laminarinase (Sigma, Germany, Product No. L5272), and quantazyme (Qbiogene, Germany, Product No. QUA0201)] and their combinations. Recombinant produced 1,6- $\beta$-glucanase (40 $\mu 1$ with $120 \mathrm{mU}$ ) as kindly supplied by Dr. M. Weig (University of Göttingen). Reducing agents (dithiothreitol and tributylphosphine) alone as well as in combinations with hydrolytic enzymes were tested to increase release of cell wall associated laccase. Additionally, different temperatures $\left(24^{\circ} \mathrm{C}\right.$ and $\left.37^{\circ} \mathrm{C}\right)$, varying amounts of cell walls and different shaking patterns were also tried. One parameter was changed at a time to obtain maximal release of laccases from the cell wall samples.

\section{Protease inhibitor assay}

Protease inhibitors were added to obtain desired concentrations in $200 \mu 1$ of $100 \mathrm{mM}$ of sodium acetate buffer $\mathrm{pH}$ 5.8. Following inhibitors were tested: PMSF - $1.0 \mathrm{mM}, 5.0$ 
$\mathrm{mM}$, and $20 \mathrm{mM}$, EDTA (ethylenediamine tetraacetic acid) $-1.0 \mathrm{mM}, 5.0 \mathrm{mM}$, and 20 $\mathrm{mM}$, PIC (protease inhibitor cocktail from Sigma, Germany, P-8215) - 1.0 $\mu 1,5.0 \mu 1$, and $20 \mu 1$, aprotinin (Sigma, Germany, A4529) - $1.0 \mu \mathrm{M}, 5.0 \mu \mathrm{M}$, and $200 \mu \mathrm{M}$, soyabean inhibitor cocktail (Sigma, Germany) - $1.0 \mu \mathrm{M}, 5.0 \mu \mathrm{M}$, and $200 \mu \mathrm{M}$ and antipanin (Sigma, Germany) - $1.0 \mu \mathrm{M}, 5.0 \mu \mathrm{M}$, and $50 \mu \mathrm{M}$.

$100 \mu \mathrm{l}$ of Trichoderma lysate cocktail from a stock of $6 \mathrm{mg}$ protein $/ \mathrm{ml}$ were added and the reaction mixture was incubated for 15 minutes at room temperature. Thereafter, $50 \mu 1$ of $3 \%$ azocasein in $10 \mathrm{mM}$ Tris- $\mathrm{HCl} \mathrm{pH} 8.0$ were added to the reaction mixture and gently mixed. The reaction tubes were incubated for 30 minutes at $37^{\circ} \mathrm{C}$ and the reaction was stopped by addition of $275 \mu \mathrm{l}$ of $20 \%$ TCA. Samples were centrifuged for 10 minutes at $13,000 \mathrm{~g}$ and the changes in absorption were measured at $\mathrm{A}_{340}$ (Carlile et al. 2000). Control values were subtracted from the samples.

\section{Protein identification by ESI-LC-MS analysis}

Stained bands were excised from 1D gels, cut into small pieces, washed once with $200 \mu 1$ of distilled water for 15 minutes and $200 \mu \mathrm{l}$ of $50 \%$ methanol, and dehydrated in $200 \mu \mathrm{l}$ of pure acetonitrile for $20 \mathrm{~min}$. In-gel digestion of proteins with trypsin was performed at $58^{\circ} \mathrm{C}$ as described by Havlis et al. (2003). The resulting peptides were extracted in two steps with $200 \mu \mathrm{l}$ of $5 \%$ formic acid and $200 \mu \mathrm{l}$ of $50 \%$ acetonitrile with $5 \%$ formic acid (30 min each step). The pooled extracts were concentrated using a vacuum concentrator and peptides were dissolved in $5 \mu 1$ of $5 \%$ formic acid for ESI-LC-MS. $4 \mu 1$ of sample was analyzed by ESI-LC-MS (Esquire-3000, Bruker Daltonics, Bremen, Germany). Gel eluted peptides were injected into the liquid chromatography columns and the corresponding peptides were passed through a high-voltage electric path for ionization in the mass spectrometer, ESI-LC-MS (Electro Spray Ionization-Liquid Chromatograph-Mass Spectrometer; Esquire-3000, Bruker Daltonics, Bremen, Germany) for mass spectrometric analysis. MS/MS spectra obtained from the ESI-MS detector were further processed by the Bruker Daltonics Data Analysis software (Interactive data processing, esquire series) and exported to the protein database and search engine Mascot (version 2.0, Matrix Science, http://www.matrixscience.com/search form_select.html) in Mascot Generic 
Format (MGF). Searches were performed first against a mass spectrometry data base (MSDB) (tp://ftp.ncbi. nih.gov/repository/MSDB/msdb.nam). In addition, an own database for Mascot analysis was created $\left(19^{\text {th }}\right.$ May 2005) with sequences from SNAP predictions and annotated protein sequences from the C. cinerea genome (J. Stajich, Duke University, unpublished, http://genome.semo.edu/cgi-bin/gbrowse/coprinus) combined with the SwissProt database, the NCBI database, the annotated Phanerochaete chrysosporium proteins, and 17 laccase sequences of $C$. cinerea annotated by S. Kilaru (unpublished). All cysteine residues were searched as reduced and methionine residues in the oxidized form. Mascot parameters were set to use monoisotopic masses with a tolerance of 1.5 for precursor ions and 0.5 for fragment ions.

\subsection{Result and discussion}

\subsubsection{Quantification of cell wall associated laccase during sample preparation}

The supernatant laccase activity in cultures of $T$. versicolor was increased by more than 23 times after induction with 2,5-xylidine as compared to non-induced controls (Table 1). This increase was also measured for mycelial laccases activity both qualitatively and quantitatively (Fig. 1, Table 1).

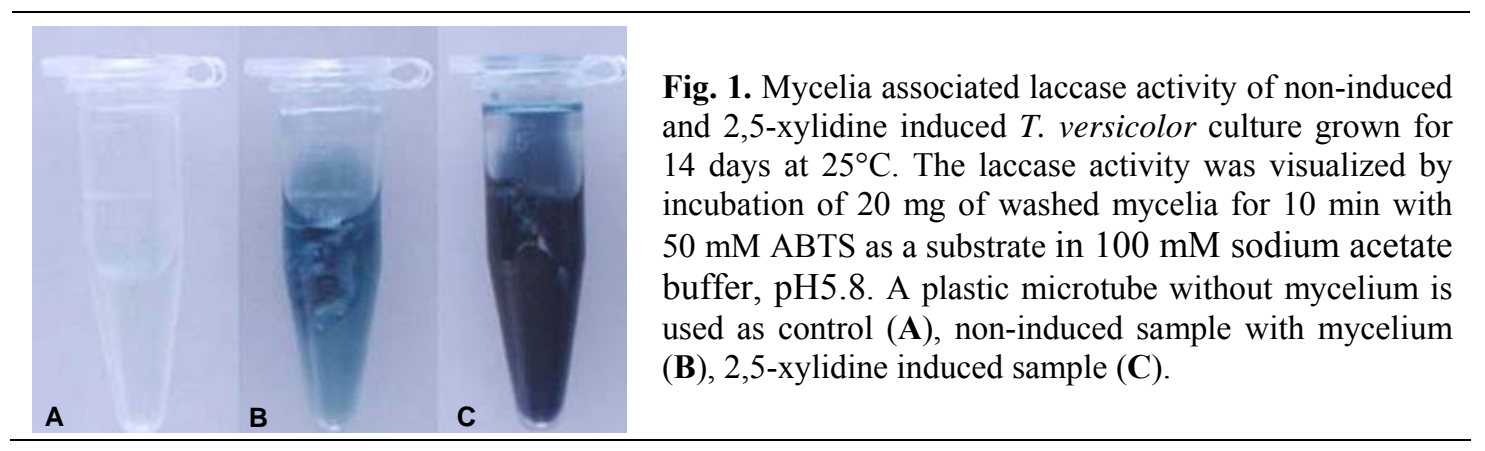

The mycelia were washed twice and were homogenized to obtain the cell wall fractions (CWF). The initial laccase activity associated with the ground CWF was $2.5 \pm 0.0 \mathrm{mU}$ and $19.8 \pm 0.23 \mathrm{mU}$ (per $10 \mathrm{mg}$ wet weight of cell wall fractions) for non-induced and 2,5-xylidine-induced cultures, respectively. Five successive washing steps with sodium acetate buffer $\mathrm{pH} 5.0$ removed most of the adsorbed supernatant laccase activity from the CWF 
(Table 1). The laccase activity bound to the CWF after the fifth wash was measured to be $1.5 \pm 0.09$ and $10.7 \pm 0.07 \mathrm{mU} / 10 \mathrm{mg}$ fresh weight of cell wall samples for non-induced and 2,5-xylidine-induced samples, respectively. The cell wall associated laccases were extracted by using various hydrolytic enzymes and their combinations, reducing agents, temperatures, amount of CWF and different shaking patterns (see Materials and methods).

Table 1. Laccase activity released into the buffer and laccase activity remaining in the cell wall fractions from a 2,5-xylidine-induced $T$. versicolor culture while grinding each $7.1 \mathrm{~g}$ of noninduced and induced mycelium during sample preparation.

\begin{tabular}{l|c|c|c|c}
\hline \multirow{2}{*}{$\begin{array}{c}\text { Cell wall } \\
\text { preparation steps }\end{array}$} & \multicolumn{2}{|c|}{ Non induced culture } & \multicolumn{2}{c}{$\mathbf{2 , 5 - X y l i d i n e ~ i n d u c e d ~ c u l t u r e ~}$} \\
\cline { 2 - 5 } & $\begin{array}{c}\text { Laccase activity } \\
\text { in wash }\end{array}$ & $\begin{array}{c}\text { Laccase activity in the } \\
\text { cell wall fractions }\end{array}$ & $\begin{array}{c}\text { Laccase activity } \\
\text { in the wash } \\
\text { solution }\end{array}$ & $\begin{array}{c}\text { Laccase activity in the } \\
\text { cell wall fractions }\end{array}$ \\
\hline After harvesting & $70.0 \pm 3.6^{+}$ & $2.6 \pm 0.17^{*}$ & $1623 \pm 12.2^{+}$ & $27.4 \pm 0.00^{*}$ \\
After mycelium grinding & $108.2 \pm 18.2$ & $2.5 \pm 0.00$ & $626.8 \pm 20.0$ & $19.8 \pm 0.23$ \\
After $1^{\text {st }}$ washing step & $15.1 \pm 0.8$ & $2.4 \pm 0.05$ & $192.8 \pm 0.7$ & $13.6 \pm 0.13$ \\
After $2^{\text {nd }}$ washing step & $6.8 \pm 3.5$ & $2.0 \pm 0.01$ & $99.7 \pm 0.2$ & $12.3 \pm 0.05$ \\
After $3^{\text {rd }}$ washing step & $4.1 \pm 0.6$ & $2.0 \pm 0.03$ & $33.4 \pm 1.4$ & $11.5 \pm 0.25$ \\
After $4^{\text {th }}$ washing step & $2.5 \pm 0.1$ & $1.7 \pm 0.02$ & $16.2 \pm 1.9$ & $10.8 \pm 16$ \\
After $5^{\text {th }}$ washing step & $1.8 \pm 0.4$ & $1.5 \pm 0.09$ & $11.3 \pm 0.3$ & $10.7 \pm 0.07$ \\
\hline
\end{tabular}

${ }^{+}$Laccase activity present in the supernatant

* Initial laccase activity present in the mycelia

\subsubsection{Optimization of conditions for release of cell wall associated laccase by lytic enzymes}

Farina and coworkers used lytic enzymes of T. harzianum in a ratio of 1:1 (w/w) enzyme to fungal biomass (mycelium) for efficient protoplasting of the filamentous ascomycete Sclerotium rolfsii (Farina et al. 2004). It has also been previously emphasized that an increase in biomass in relation to the lytic mixture does not automatically yield higher numbers of protoplasts since this depends on the fact that the enzyme does not necessarily become limiting, and on the organism, and on the lytic conditions in general. Thus, the optimal biomass:enzyme ratio needs to be investigated for each individual fungal strain (Curragh et al. 1992). Since the cell wall of higher basidiomycetes also consists of more or less similar building blocks (Ruiz-Herrera 1992), similar ratios of isolated cell walls 
and lytic enzymes were used here to release cell wall-associated laccase. For $20 \mathrm{mg}$ wet weight of cell walls from a 2,5-xylidine-induced $T$. versicolor cultures (which corresponds to $2.6 \mathrm{mg}$ dry weight of isolated cell wall samples), lytic enzymes in ratios of 1:0.15, 1:0.3, and 1:0.6 dry biomass:enzyme ratio $(\mathrm{w} / \mathrm{w})$ were tested for releasing proteins from cell walls of T. versicolor in a test volume of $1.0 \mathrm{ml} 100 \mathrm{mM}$ sodium acetate buffer buffer, pH 5.8 in a $1.5 \mathrm{ml}$ plastic microtube: per $2.6 \mathrm{mg}$ dry weight of cell walls, $0.39 \mathrm{mg}, 0.78 \mathrm{mg}$ and $1.56 \mathrm{mg}$ of $1 \mathrm{U} / \mathrm{mg}$ cellulose, $0.39 \mathrm{mg}, 0.78 \mathrm{mg}$ and $1.56 \mathrm{mg}$ of 0.2 $\mathrm{U} / \mathrm{mg}$ chitinase, and $0.39 \mathrm{mg}, 0.78 \mathrm{mg}$ and $1.56 \mathrm{mg}$ of $2 \mathrm{U} / \mathrm{mg}$ Trichoderma lysate were used, respectively.

Treatments with cellulose, chitinase, and Trichoderma lysate were all three successful in obtaining upon $24 \mathrm{~h}$ incubation high laccase activity in the buffer at the ratios of 1:0.3 and 1:0.6 dry biomass:enzyme, respectively (Table 2, experiments 2 and 3). In contrast, there were no significant differences when using lytic enzymes only at dry biomass:enzyme ratio of 1:0.15 (Table 2, experiment 1). At the second highest enzyme concentrations, there was a clear effect in higher levels of laccase activities in the buffer in samples with the enzymes as compared to the control sample (Table 2, experiment 2). In the cell wall, there was only in case of Trichoderma lysate an obvious reduction of enzyme activity in the cell wall as compared in the control. In consequence of this, the total enzymatic activity from the sample did not differ from the control samples (see Table 2, experiment 2). At the highest enzyme concentration tested, all three sets of samples treated with enzyme resulted in higher activities in the buffer as compared to the control, as well as higher activities in total in the samples (Table 2, experiment 3). Interestingly, in the cellulose sample, the double amount of enzyme was found in the cell walls as compared to the control in contrast to the Trichoderma lysate sample that had only half the amount of activity left in the cell wall (Table 2, experiment 3). Regarding to the efficiency of lytic enzymes on release of laccase from the cell walls, these results are difficult to interpret. Obviously as can be seen in the controls, part of the laccase activities are freely released by diffusion from the cell walls. However, much of the initial laccase activity is lost and this could have happened in the buffer after release, in the cell wall of unreleased activity or both. In the cases of addition of enzymes it could therefore be that either more enzyme 
was released into the buffer and thus saved against proteolytic degradation within the cell wall or freely or enzyme-mediated released laccase activities were stabilized in the buffer against proteolytic degradation.

Overall, treatment with cellulase and chitinase lead to higher levels of released laccase in the buffer as compared to Trichoderma lysate (Table 2, experiment 2 and 3). Cellulase treatment was best over the other enzyme preparations at the ratio 1:0.6 dry biomass/enzyme (w/w), and chitinase treatment at the ratio 1:0.3 dry biomass/enzyme (w/w), respectively (Table 2, experiment 3 and experiment 2, respectively). With $17.5 \%$ and $17.3 \%$, respectively, the extra amount of released laccase in presence of cellulase at the ratio 1:0.6 dry biomass/enzyme $(\mathrm{w} / \mathrm{w})$ was comparable to the extra amount in presence of chitinase at the ratio 1:0.3 dry biomass/enzyme $(\mathrm{w} / \mathrm{w})$.

It can further be deduced from this analysis that increase in concentration of chitinase and of Trichoderma lysate will probably not further optimize amounts of released enzyme. For chitinase, the optimum amount of released laccase was at the 1:0.3 dry biomass/enzyme (w/w) and for Trichoderma lysate, there was no significant increase in amount of released with the change from 1:0.3 dry biomass/enzyme (w/w) to 1:0.6 dry biomass/enzyme $(\mathrm{w} / \mathrm{w})$. Only in the case of cellulose, with a further increase in enzyme concentration one still might find also a further increase in the amount of released laccase in the buffer after incubation.

As discussed above, the available data do not allow to conclude whether addition of cell wall degrading enzymes helped to release more laccase from the cell wall samples into the buffer, or whether addition of these enzymes helped in protection of proteins in the buffer and/or in the cell walls against any proteolytic activities (see below). In total in the controls, $5.07 \pm 0.76$ (experiment 1), $3.71 \pm 0.52 \mathrm{mU}$ (experiment 2) and $3.83 \pm 0.96$ (experiment 3) were left at the end of the experiment, representing $47.0 \%, 34.7 \%$ and $35.8 \%$ of the initial laccase activity, respectively. In the series of enzyme-treated samples, the total amount at the end of the experiment was often higher, arguing for a possible protection against proteolytic activities (see Table 2 and below). Only in the case of Trichoderma lysate, despite of an increased total amount of laccase left at the end of the experiment, the amount remained in the cell wall was lower than the control. This 
together can indicate, that the added enzyme was active in release of laccase from the cell wall. For the other two enzymes, no such conclusion can be given with the results presented in this work.

Three other lytic enzymes were tested in this study with little positive result (experiment 4, Table 2):

$0.78 \mathrm{mg}$ of dry cell walls were treated with $0.1 \mathrm{U} / \mathrm{mg}$ laminarinase, respectively (for results see Table 2 and text below), but laccase activities in the buffer and in the cell walls were indistinguishable from the control sample without enzyme (see Table 2, experiment 4 and also Table 3).

Table 2. Enzymes and their concentrations applied in $1.0 \mathrm{ml}$ of $100 \mathrm{mM}$ sodium acetate buffer, pH 5.8 in $1.5 \mathrm{ml}$ plastic tubes to obtain maximum release of laccase from isolated cell wall samples $(20.0 \mathrm{mg}$ wet weight from a 2,5-xylidine-induced culture of T. versicolor*, which corresponds to $10.7 \pm 0.07 \mathrm{mU}$ laccase**) after $24 \mathrm{~h}$ incubation at room temperature.

\begin{tabular}{|c|c|c|c|c|}
\hline Name of enzyme & $\begin{array}{l}\text { Total laccase } \\
\text { activity in the } \\
\text { buffer after } \\
\text { incubation } \\
\text { (mU) }\end{array}$ & $\begin{array}{c}\text { Extra } \\
\text { activity/loss of } \\
\text { laccase by } \\
\text { enzyme } \\
\text { addition (mU) }\end{array}$ & $\begin{array}{l}\text { Remaining } \\
\text { activity in the } \\
\text { cell walls after } \\
\text { enzyme } \\
\text { treatment (mU) }\end{array}$ & $\begin{array}{l}\text { Activity left in } \\
\text { total after } 24 \mathrm{~h} \\
\text { incubation } \\
\text { (mU) }\end{array}$ \\
\hline \multicolumn{5}{|l|}{$\begin{array}{l}\text { Experiment } 1 * * * \text { : } \\
0.15 \mathrm{mg} \text { enzyme } / \mathrm{mg}\end{array}$} \\
\hline $\begin{array}{c}\text { Control experiment } \\
1\end{array}$ & $\begin{array}{c}3.254 \pm 0.74 \\
(30.4 \% \text { of } \\
\text { initial activity) }\end{array}$ & - & $\begin{array}{c}1.773 \pm 0.02 \\
(16.6 \% \text { of initial } \\
\text { activity) }\end{array}$ & $\begin{array}{c}5.027 \pm 0.76 \\
(47.0 \% \text { of initial } \\
\text { activity) }\end{array}$ \\
\hline Cellulase $\mathrm{fr}$ & $3.774 \pm 2.5$ & $0.52 \pm 2.5$ & $1.632 \pm 0.02$ & $5.406=$ \\
\hline Trichoo & $\begin{array}{c}(35.3 \% \text { of } \\
\text { initial activity) }\end{array}$ & $\begin{array}{c}(4.9 \% \text { extra } \\
\text { activity) }\end{array}$ & $\begin{array}{l}\text { ( } 15.3 \% \text { of initial } \\
\text { activity, i.e. } 92.0 \% \\
\text { of final activity in } \\
\text { the control sample) }\end{array}$ & $\begin{array}{l}(50.5 \% \text { of initial } \\
\text { activity; } 107.5 \% \text { of } \\
\text { final activity in the } \\
\text { control sample })\end{array}$ \\
\hline Chitinase from & $2.761 \pm 1.81$ & $-0.49 \pm 1.87$ & $1.454 \pm 0.02$ & $4.215 \pm 1.89$ \\
\hline Trichoderm & $\begin{array}{l}(25.8 \% \text { of } \\
\text { initial activity })\end{array}$ & $\begin{array}{l}(4.6 \% \text { loss of } \\
\text { activity) }\end{array}$ & $\begin{array}{l}\text { (13.6\% of initial } \\
\text { activity, i.e. } 82.0 \% \\
\text { of final activity in } \\
\text { the control sample) }\end{array}$ & $\begin{array}{l}(39.4 \% \text { of initial } \\
\text { activity; } 83.8 \% \text { of } \\
\text { final activity in the } \\
\text { control sample) }\end{array}$ \\
\hline $\begin{array}{c}\text { Trichoderma lysate } \\
\text { from Trichoderma } \\
\text { harzianum }\end{array}$ & $\begin{array}{c}3.181 \pm 1.16 \\
(29.7 \% \text { of } \\
\text { initial activity })\end{array}$ & $\begin{array}{c}-0.07 \pm 1.16 \\
(0.7 \% \text { loss of } \\
\text { activity })\end{array}$ & $\begin{array}{l}1.479 \pm 0.02 \\
(13.8 \% \text { of initial } \\
\text { activity, i.e. } 83.4 \% \\
\text { of final activity in } \\
\text { the control sample) }\end{array}$ & $\begin{array}{c}4.660 \pm 1.18 \\
\text { (43.6\% of initial } \\
\text { activity; } 92.7 \% \text { of } \\
\text { final activity in the } \\
\text { control sample) }\end{array}$ \\
\hline \multicolumn{5}{|c|}{$\begin{array}{l}\text { Dry weights of cell walls were calculated by drying the cell wall pellet at } 105^{\circ} \mathrm{C} \text { for two days and } \\
\text { weighing the mycelia. Subsequently, the dry weights were correlated to the wet weights. Accordingly, } \\
10 \mathrm{mg} \text { of wet weight corresponds to } 1.3 \mathrm{mg} \text { of dry weight. The same material as that in Table } 1 \text { was used. } \\
* * 10.7 \pm 0.07 \mathrm{mU} \text { of laccase were present in } 20 \mathrm{mg} \text { cell walls (wet weight) at the start of the experiment. } \\
\text { k* All values are averages of three independent reactions. }\end{array}$} \\
\hline
\end{tabular}


Table 2 (continued)

\begin{tabular}{|c|c|c|c|c|}
\hline Name of enzyme & $\begin{array}{l}\text { Total laccase } \\
\text { activity in the } \\
\text { buffer after } \\
\text { incubation } \\
\text { (mU) }\end{array}$ & $\begin{array}{c}\text { Extra } \\
\text { activity/loss of } \\
\text { laccase by } \\
\text { enzyme } \\
\text { addition (mU) }\end{array}$ & $\begin{array}{l}\text { Remaining } \\
\text { activity in the } \\
\text { cell walls after } \\
\text { enzyme } \\
\text { treatment (mU) }\end{array}$ & $\begin{array}{l}\text { Activity left in } \\
\text { total after } 24 \mathrm{~h} \\
\text { incubation } \\
(\mathrm{mU})\end{array}$ \\
\hline \multicolumn{5}{|l|}{$\begin{array}{l}\text { Experiment } 2 * * * \text { : } \\
0.3 \mathrm{mg} \text { enzyme } / \mathrm{mg} \mathrm{d}\end{array}$} \\
\hline $\begin{array}{l}\text { Control experiment } \\
2\end{array}$ & $\begin{array}{c}2.017 \pm 0.48 \\
(18.9 \% \text { of } \\
\text { initial activity) }\end{array}$ & - & $\begin{array}{c}1.691 \pm 0.04 \\
(15.8 \% \text { of initial } \\
\text { activity) }\end{array}$ & $\begin{array}{c}3.708 \pm 0.52 \\
\text { (34.7 \% of initial } \\
\text { activity) }\end{array}$ \\
\hline $\begin{array}{l}\text { Cellulase from } \\
\text { Trichoderma reesei }\end{array}$ & $\begin{array}{c}2.685 \pm 0.19 \\
(25.1 \% \text { of } \\
\text { initial activity })\end{array}$ & $\begin{array}{c}0.66 \pm 0.19 \\
(6.2 \% \text { extra } \\
\text { activity) }\end{array}$ & $\begin{array}{c}1.778 \pm 0.04 \\
(16.6 \% \text { of initial } \\
\text { activity, i.e. } 105.1 \\
\% \text { of final activity } \\
\text { in the control } \\
\text { sample) }\end{array}$ & $\begin{array}{c}4.463 \pm 2.23 \\
(41.7 \% \text { of initial } \\
\text { activity; } 120.3 \% \\
\text { of final activity in } \\
\text { the control sample) }\end{array}$ \\
\hline $\begin{array}{l}\text { Chitinase from } \\
\text { Trichoderma reesei }\end{array}$ & $\begin{array}{c}3.865 \pm 1.59 \\
(36.1 \% \text { of } \\
\text { initial activity) }\end{array}$ & $\begin{array}{c}1.84 \pm 1.59 \\
(17.3 \% \text { extra } \\
\text { activity })\end{array}$ & $\begin{array}{l}1.381 \pm 0.04 \\
\text { (12.9\% of initial } \\
\text { activity, i.e. } 81.7 \% \\
\text { of final activity in } \\
\text { the control sample) }\end{array}$ & $\begin{array}{c}5.246 \pm 1.63 \\
(49.0 \% \text { of initial } \\
\text { activity; } 141.4 \% \text { of } \\
\text { final activity in the } \\
\text { control sample) }\end{array}$ \\
\hline $\begin{array}{c}\text { Trichoderma lysate } \\
\text { from Trichoderma } \\
\text { harzianum }\end{array}$ & $\begin{array}{c}3.079 \pm 0.75 \\
(28.8 \% \text { of } \\
\text { initial activity })\end{array}$ & $\begin{array}{c}1.06 \pm 0.75 \\
(9.9 \% \text { extra } \\
\text { activity) }\end{array}$ & $\begin{array}{l}0.662 \pm 0.00 \\
(6.2 \% \text { of initial } \\
\text { activity, i.e. } 39.1 \% \\
\text { of final activity in } \\
\text { the control sample })\end{array}$ & $\begin{array}{l}3.741 \pm 0.75 \\
(35.0 \% \text { of initial } \\
\text { activity; } 100.8 \% \text { of } \\
\text { final activity in the } \\
\text { control sample) }\end{array}$ \\
\hline \multicolumn{5}{|c|}{$\begin{array}{l}\text { Experiment } 3 * * * \text { : } \\
0.6 \mathrm{mg} \text { enzyme/ } \mathrm{mg} \text { dry weight of cell walls* }(1.56 \mathrm{mg} \text { enzyme } / 2.6 \mathrm{mg} \text { dry weight of cell walls })\end{array}$} \\
\hline $\begin{array}{l}\text { Control experiment } \\
3\end{array}$ & $\begin{array}{c}2.659 \pm 0.96 \\
(24.9 \% \text { of } \\
\text { initial activity) }\end{array}$ & 107 & $\begin{array}{c}1.169 \pm 0.00 \\
(10.9 \% \text { of initial } \\
\text { activity) }\end{array}$ & $\begin{array}{c}3.828 \pm 0.96 \\
\text { (35.8\% of initial } \\
\text { activity) }\end{array}$ \\
\hline Cellulase from & $4.533 \pm 2.44$ & $1.87 \pm 2.44$ & $2.397 \pm 0.00$ & $6.930 \pm 2.44$ \\
\hline Trichoderma reesei & $\begin{array}{l}(42.3 \% \text { of } \\
\text { initial activity })\end{array}$ & $\begin{array}{l}(17.5 \% \text { extra } \\
\text { activity) }\end{array}$ & $\begin{array}{l}\text { (22.4\% of initial } \\
\text { activity, i.e. } 205.0 \\
\% \text { of final activity } \\
\text { in the control } \\
\text { sample) }\end{array}$ & $\begin{array}{l}(64.8 \% \text { of initial } \\
\text { activity; } 181.0 \% \text { of } \\
\text { final activity in the } \\
\text { control sample) }\end{array}$ \\
\hline $\begin{array}{l}\text { Chitinase from } \\
\text { Trichoderma reesei }\end{array}$ & $\begin{array}{c}3.419 \pm 0.61 \\
(32.0 \% \text { of } \\
\text { initial activity) }\end{array}$ & $\begin{array}{c}0.76 \pm 0.61 \\
(7.1 \% \text { extra } \\
\text { activity) }\end{array}$ & $\begin{array}{c}1.417 \pm 0.03 \\
(13.2 \% \text { of initial } \\
\text { activity, i.e. } 121.2 \\
\% \text { of final activity } \\
\text { in the control } \\
\text { sample) }\end{array}$ & $\begin{array}{l}4.836 \pm 0.64 \\
(45.2 \% \text { of initial } \\
\text { activity; } 126.3 \% \text { of } \\
\text { final activity in the } \\
\text { control sample) }\end{array}$ \\
\hline $\begin{array}{c}\text { Trichoderma lysate } \\
\text { from Trichoderma } \\
\text { harzianum }\end{array}$ & $\begin{array}{c}3.744 \pm 0.05 \\
(35.0 \% \text { of } \\
\text { initial activity })\end{array}$ & $\begin{array}{c}1.08 \pm 0.05 \\
(10.1 \% \text { extra } \\
\text { activity) }\end{array}$ & $\begin{array}{c}0.631 \pm 0.01 \\
(5.9 \% \text { of initial } \\
\text { activity, i.e. } 54.0 \% \\
\text { of final activity in } \\
\text { the control sample) }\end{array}$ & $\begin{array}{c}4.375 \pm 0.06 \\
(40.9 \% \text { of initial } \\
\text { activity; } 114.2 \% \text { of } \\
\text { final activity in the } \\
\text { control sample) }\end{array}$ \\
\hline
\end{tabular}


Table 2 (continued)

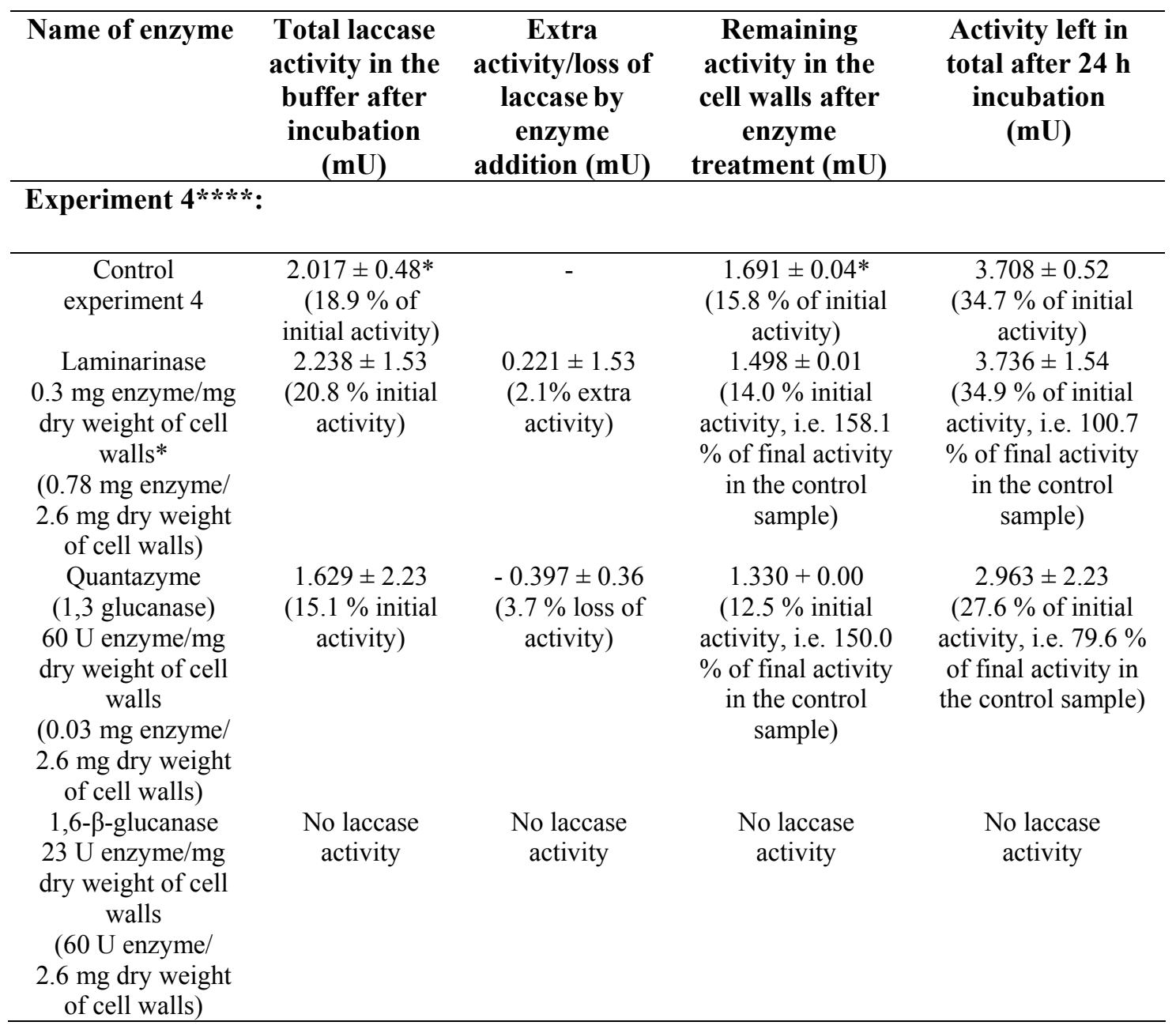

**** All values are averages of three independent reactions but the 1,6- $\beta$-glucanase sample that was tested only once. Note that in experiment 4 , the laccase activity within the $20 \mathrm{mg}$ of cell walls (wet weight) was not rechecked and that some of the values given here for experiment 4 are repeated in Table 3 .

In case of quantazyme (2000 U/mg), $60 \mathrm{U}$ of enzyme (0.03 $\mathrm{mg}$ of enzyme) was used for $2.6 \mathrm{mg}$ dry weight of cell walls (= $20 \mathrm{mg}$ wet biomass) at a ratio 1:87 dry biomass:enzyme $(\mathrm{w} / \mathrm{w})$ - higher concentrations of the highly purified enzyme were not tested by the high prize of the enzyme. Quantazyme did not lead to any increase in laccase activity in the buffer under the conditions tested, respectively a decrease in laccase activity remaining in the cell walls as compared to the control (Table 2, experiment 4 and Table 3 ). 
Table 3. Release of cell wall-associated laccase from 2,5-xylidine induced culture of $T$. versicolor after incubation of $20 \mathrm{mg}$ cell walls (wet weight, corresponding to an initial laccase activity of $10.7 \pm 0.07 \mathrm{mU}^{*}$ ) from a 2,5-xylidine-induced culture for $24 \mathrm{hrs}$ at room temperature in $1.0 \mathrm{ml}$ of $100 \mathrm{mM}$ sodium acetate buffer, $\mathrm{pH} 5.8 \mathrm{in}$ as $1.5 \mathrm{ml}$ plastic tube in presence of different hydrolytic enzymes / reducing agents and remaining laccase activity in the used cell wall samples.

\begin{tabular}{|c|c|c|c|c|}
\hline $\begin{array}{l}\text { Cell wall } \\
\text { treatment with } \\
\text { different lytic } \\
\text { enzymes and } \\
\text { chemicals }\end{array}$ & $\begin{array}{l}\text { Released laccase } \\
\text { from the cell } \\
\text { walls (mU/20 mg } \\
\text { wet weight) } \\
\text { (absolute values) }\end{array}$ & $\begin{array}{c}\text { Extra release/ } \\
\text { loss of laccase } \\
\text { by enzyme } \\
\text { addition } \\
(\mathbf{m U})^{* *}\end{array}$ & $\begin{array}{c}\text { Remaining } \\
\text { laccase in the cell } \\
\text { walls } \\
\text { (mU/20 mg wet } \\
\text { weight) }\end{array}$ & $\begin{array}{c}\text { Activity left } \\
\text { in total after } \\
24 \mathrm{~h} \text { of } \\
\text { incubation } \\
\text { (mU) }\end{array}$ \\
\hline $\begin{array}{l}\text { Control ( } 2.6 \mathrm{mg} \text { dry } \\
\text { weight of cell wall } \\
\text { without any } \\
\text { enzyme) }\end{array}$ & $\begin{array}{c}2.017 \pm 0.48^{*} \\
(18.9 \% \text { of initial } \\
\text { activity) }\end{array}$ & - & $\begin{array}{c}1.691 \pm 0.04^{*} \\
(15.8 \% \text { of initial } \\
\text { activity) }\end{array}$ & $\begin{array}{c}3.708 \pm 0.52 \\
(34.7 \% \text { of } \\
\text { initial activity) }\end{array}$ \\
\hline $\begin{array}{l}50 \mathrm{mM} \\
\text { dithiothreitol, no } \\
\text { enzyme }\end{array}$ & $\begin{array}{c}0.0 \pm 0.0 \\
(0 \% \text { of initial } \\
\text { activity })\end{array}$ & - & $\begin{array}{c}0.0 \pm 0.0 \\
(0.0 \% \text { of initial } \\
\text { activity })\end{array}$ & $\begin{array}{c}0.00 \pm 0.00 \\
(0.0 \% \text { of initial } \\
\text { activity, i.e. } 0.0 \\
\% \text { of final } \\
\text { activity in the } \\
\text { control sample })\end{array}$ \\
\hline $\begin{array}{l}1 \mathrm{mM} \\
\text { tributylphosphine, } \\
\text { no enzyme }\end{array}$ & $\begin{array}{c}1.765 \pm 0.60 \\
\text { (16.5\% of initial } \\
\text { activity) }\end{array}$ & - & $\begin{array}{c}0.886 \pm 0.01 \\
(8.3 \% \text { of initial } \\
\text { activity })\end{array}$ & $\begin{array}{c}2.651 \pm 0.62 \\
(24.7 \% \text { of } \\
\text { initial activity, } \\
\text { i.e. } 71.4 \% \text { of } \\
\text { final activity in } \\
\text { the control } \\
\text { sample) }\end{array}$ \\
\hline $\begin{array}{l}\text { Cellulase } \\
(0.78 \mathrm{mg} / 2.6 \mathrm{mg} \\
\text { dry weight of cell } \\
\text { walls })\end{array}$ & $\begin{array}{c}2.685 \pm 0.19 \\
(25.1 \% \text { of initial } \\
\text { activity) }\end{array}$ & $\begin{array}{c}0.667 \\
(6.2 \% \text { extra } \\
\text { activity) }\end{array}$ & $\begin{array}{c}1.778 \pm 0.01 \\
\text { (16.6\% of initial } \\
\text { activity) }\end{array}$ & $\begin{array}{c}4.463 \pm 0.20 \\
(41.6 \% \text { of } \\
\text { initial activity, } \\
\text { i.e. } 120.3 \% \text { of } \\
\text { final activity in } \\
\text { the control } \\
\text { sample) }\end{array}$ \\
\hline $\begin{array}{l}\text { Cellulase } \\
(0.78 \mathrm{mg} / 2.6 \mathrm{mg} \\
\text { dry weight of cell } \\
\text { walls })+1 \mathrm{mM} \\
\text { tributylphosphine }\end{array}$ & $\begin{array}{c}1.944 \pm 2.26 \\
\text { (18.2\% of initial } \\
\text { activity) }\end{array}$ & $\begin{array}{c}-0.073 \\
(-0.7 \% \text { of initial } \\
\text { activity) }\end{array}$ & $\begin{array}{c}1.094 \pm 0.0 \\
(10.2 \% \text { of initial } \\
\text { activity) }\end{array}$ & $\begin{array}{c}3.038 \pm 2.26 \\
(28.3 \% \text { of } \\
\text { initial activity, } \\
\text { i.e. } 81.9 \% \text { of } \\
\text { final activity in } \\
\text { the control } \\
\text { sample) }\end{array}$ \\
\hline
\end{tabular}


Table 3 (continued)

\begin{tabular}{|c|c|c|c|c|}
\hline $\begin{array}{l}\text { Cell wall } \\
\text { treatment with } \\
\text { different lytic } \\
\text { enzymes and } \\
\text { chemicals }\end{array}$ & $\begin{array}{c}\text { Released laccase } \\
\text { from the cell } \\
\text { walls (mU/20 } \mathrm{mg} \\
\text { wet weight) } \\
\text { (absolute values) }\end{array}$ & $\begin{array}{c}\text { Extra release/ } \\
\text { loss of laccase } \\
\text { by enzyme } \\
\text { addition } \\
(\mathbf{m} U)^{* *}\end{array}$ & $\begin{array}{c}\text { Remaining } \\
\text { laccase in the cell } \\
\text { walls } \\
\text { (mU/20 mg wet } \\
\text { weight) }\end{array}$ & $\begin{array}{c}\text { Activity left } \\
\text { in total after } \\
24 \mathrm{~h} \text { of } \\
\text { incubation } \\
\text { (mU) }\end{array}$ \\
\hline $\begin{array}{l}\text { Chitinase }(0.78 \\
\mathrm{mg} / 2.6 \mathrm{mg} \text { dry } \\
\text { weight of cell } \\
\text { walls })\end{array}$ & $\begin{array}{c}3.865 \pm 1.59 \\
\text { (36.1 \% of initial } \\
\text { activity) }\end{array}$ & $\begin{array}{c}1.848 \\
(17.3 \% \text { extra } \\
\text { activity })\end{array}$ & $\begin{array}{c}1.381 \pm 0.04 \\
(12.9 \% \text { of initial } \\
\text { activity) }\end{array}$ & $\begin{array}{c}5.246 \pm 1.63 \\
(49.0 \% \text { of } \\
\text { initial activity, } \\
\text { i.e. } 141.4 \% \text { of } \\
\text { final activity in } \\
\text { the control } \\
\text { sample })\end{array}$ \\
\hline $\begin{array}{l}\text { Chitinase }(0.78 \\
\mathrm{mg} / 2.6 \mathrm{mg} \text { dry } \\
\text { weight of cell } \\
\text { walls })+1 \mathrm{mM} \\
\text { tributylphosphine }\end{array}$ & $\begin{array}{c}2.670 \pm 0.13 \\
(25.0 \% \text { of initial } \\
\text { activity) }\end{array}$ & $\begin{array}{c}0.652 \\
(6.1 \% \text { extra } \\
\text { activity) }\end{array}$ & $\begin{array}{c}1.388 \pm 0.01 \\
(13.0 \% \text { of initial } \\
\text { activity) }\end{array}$ & $\begin{array}{c}4.058 \pm 0.13 \\
(37.9 \% \text { of } \\
\text { initial activity, } \\
\text { i.e. } 109.4 \% \text { of } \\
\text { final activity in } \\
\text { the control } \\
\text { sample) }\end{array}$ \\
\hline $\begin{array}{l}\text { Trichoderma lysate } \\
(0.78 \mathrm{mg} / 2.6 \mathrm{mg} \\
\text { dry weight of cell } \\
\text { walls) }\end{array}$ & $\begin{array}{c}3.077 \pm 0.75 \\
(8.0 \% \text { of initial } \\
\text { activity) }\end{array}$ & $\begin{array}{c}1.060 \\
(9.9 \% \text { extra } \\
\text { activity) }\end{array}$ & $\begin{array}{c}0.662 \pm 0.0 \\
(6.2 \% \text { of initial } \\
\text { activity })\end{array}$ & $\begin{array}{c}3.739 \pm 0.75 \\
(34.9 \% \text { of } \\
\text { initial activity, } \\
\text { i.e. } 100.8 \% \text { of } \\
\text { final activity in } \\
\text { the control } \\
\text { sample) }\end{array}$ \\
\hline $\begin{array}{l}\text { Trichoderma lysate } \\
(0.78 \mathrm{mg} / 2.6 \mathrm{mg} \\
\text { dry weight of cell } \\
\text { walls })+1 \mathrm{mM} \\
\text { tributylphosphine }\end{array}$ & $\begin{array}{c}0.116 \pm 0.22 \\
\text { (1.1\% of initial } \\
\text { activity) }\end{array}$ & $\begin{array}{c}-1.901 \\
(-17.8 \% \text { of } \\
\text { initial activity) }\end{array}$ & $\begin{array}{c}0.491 \pm 0.02 \\
(4.6 \% \text { of initial } \\
\text { activity) }\end{array}$ & $\begin{array}{c}0.607 \pm 0.24 \\
(5.6 \% \text { of initial } \\
\text { activity, i.e. } \\
16.3 \% \text { of final } \\
\text { activity in the } \\
\text { control sample) }\end{array}$ \\
\hline $\begin{array}{l}\text { Laminarinase (60 U } \\
\text { enzyme/mg dry } \\
\text { weight of cell } \\
\text { walls) }\end{array}$ & $\begin{array}{c}2.238 \pm 1.53 \\
(20.9 \% \text { of initial } \\
\text { activity) }\end{array}$ & $\begin{array}{c}0.220 \\
(2.1 \% \text { extra } \\
\text { activity) }\end{array}$ & $\begin{array}{c}1.498 \pm 0.01 \\
(14.0 \% \text { of initial } \\
\text { activity) }\end{array}$ & $\begin{array}{c}3.736 \pm 1.54 \\
(34.9 \% \text { of } \\
\text { initial activity, } \\
\text { i.e. } 100.7 \% \text { of } \\
\text { final activity in } \\
\text { the control } \\
\text { sample) }\end{array}$ \\
\hline $\begin{array}{l}\text { Laminarinase }(0.78 \\
\mathrm{mg} \text { enzyme } / 2.6 \mathrm{mg} \\
\text { dry weight of cell } \\
\text { walls })+1 \mathrm{mM} \\
\text { tributylphosphine }\end{array}$ & $\begin{array}{c}2.142 \pm 0.09 \\
(20.0 \% \text { of initial } \\
\text { activity) }\end{array}$ & $\begin{array}{c}0.125 \\
(1.2 \% \text { extra } \\
\text { activity) }\end{array}$ & $\begin{array}{c}1.256 \pm 0.0 \\
(11.7 \% \text { of initial } \\
\text { activity) }\end{array}$ & $\begin{array}{c}3.399 \pm 0.10 \\
(31.7 \% \text { of } \\
\text { initial activity, } \\
\text { i.e. } 91.6 \% \text { of } \\
\text { final activity in } \\
\text { the control } \\
\text { sample) }\end{array}$ \\
\hline
\end{tabular}


Table 3 (continued)

\begin{tabular}{|c|c|c|c|c|}
\hline $\begin{array}{l}\text { Cell wall } \\
\text { treatment with } \\
\text { different lytic } \\
\text { enzymes and } \\
\text { chemicals }\end{array}$ & $\begin{array}{c}\text { Released laccase } \\
\text { from the cell } \\
\text { walls (mU/20 mg } \\
\text { wet weight) } \\
\text { (absolute values) }\end{array}$ & $\begin{array}{c}\text { Extra release/ } \\
\text { loss of laccase } \\
\text { by enzyme } \\
\text { addition } \\
(\mathrm{mU}) * *\end{array}$ & $\begin{array}{c}\text { Remaining } \\
\text { laccase in the cell } \\
\text { walls } \\
\text { (mU/20 mg wet } \\
\text { weight) }\end{array}$ & $\begin{array}{c}\text { Activity left } \\
\text { in total after } \\
24 \mathrm{~h} \text { of } \\
\text { incubation } \\
(\mathrm{mU})\end{array}$ \\
\hline Quantazyme (60 & $1.629 \pm 2.23$ & -0.388 & $1.334 \pm 0.0$ & $2.963 \pm 2.23$ \\
\hline $\begin{array}{l}\mathrm{U} / 2.6 \mathrm{mg} \text { dry } \\
\text { weight of cell } \\
\text { walls) }\end{array}$ & $\begin{array}{c}(15.2 \% \text { of initial } \\
\text { activity) }\end{array}$ & $\begin{array}{c}(3.6 \% \text { of initial } \\
\text { activity) }\end{array}$ & $\begin{array}{c}(12.5 \% \text { of initial } \\
\text { activity) }\end{array}$ & $\begin{array}{c}(27.6 \% \text { of } \\
\text { initial activity, } \\
\text { i.e. } 79.6 \% \text { of } \\
\text { final activity in } \\
\text { the control } \\
\text { sample })\end{array}$ \\
\hline $\begin{array}{l}\text { Quantazyme ( } 60 \mathrm{U} \\
\text { enzyme } / 2.6 \mathrm{mg} \text { dry } \\
\text { weight of cell } \\
\text { walls) }+1 \mathrm{mM} \\
\text { tributylphosphine }\end{array}$ & $\begin{array}{c}2.028 \pm 0.10 \\
\text { (19.0\% of initial } \\
\text { activity) }\end{array}$ & $\begin{array}{c}0.011 \\
(0.1 \% \text { extra } \\
\text { activity })\end{array}$ & $\begin{array}{c}1.560 \pm 0.01 \\
(14.6 \% \text { of initial } \\
\text { activity) }\end{array}$ & $\begin{array}{l}\quad 3.589 \pm 0.11 \\
\text { (33.5\% of } \\
\text { initial activity, } \\
\text { i.e. } 96.7 \% \text { of } \\
\text { final activity in } \\
\text { the control } \\
\text { sample) }\end{array}$ \\
\hline
\end{tabular}

By the limited availability of 1,6- $\beta$-glucanase, per $2.6 \mathrm{mg}$ dry weight of cell walls, only $60 \mathrm{U}$ of $1,6-\beta$-glucanase $(20 \mu \mathrm{l}$ of the enzyme stock as obtained from M. Weig) was tested. Neither in buffer, nor in the cell walls treated with 1,6-ß-glucanase any laccase activity was observed (Table 2, experiment 4), suggesting that the enzyme was highly contaminated with proteases.

\subsubsection{Effect of reducing agents on release of laccase from $T$. versicolor cell walls}

Reducing agents increase porosity of the cell wall and help in removal of non-covalently bound proteins associated with the cell wall. Dithiothreitol (DTT) and tributylphosphine (TBP) either alone or in combination with lytic enzymes were used in trials to increase the release of laccase from the cell wall samples (Table 3). DTT killed all laccase activity as already reported before in T. versicolor by Johannes et al. (2000) and was not considered further. On the other hand, TBP alone lead to some reduction of laccase activity in both buffer and cell walls as compared to the control (Table 3). In combination with enzymes, similar tendencies as in the control samples are seen with some reduction of laccases activities in both buffer and cell walls in presence of TBP (Table 3). Note that in this second experiment with dry biomass:enzyme ratios of 1:0.6, the effects of 
cellulose, chitinase and Trichoderma lysate on laccase activities in buffer and cell walls after incubation showed similar tendencies than in the previously described experiment, although the laccase activities in the buffer and the activities in total in the samples were at lower levels than in the earlier experiment (compare Table 2, experiment 3 and Table 3). Only with Trichoderma lysate, regardless whether TBP was added or not, a significant decrease in enzyme activity within the cell walls were observed (Table 3).

Except quantazyme, all the other enzymes used for release of the cell wall-associated laccase were crude extracts (see product descriptions by the companies from which enzymes were purchased), which might be contaminated with proteases. Since proteases could suppress the efficiency of laccase or kill the laccase activity, protease activity in the crude enzyme samples was quantified and various protease inhibitors either alone or in combination were tested to achieve maximum inhibition of the proteases.

\subsubsection{Protease contamination in lytic enzymes}

Protease activity present in the enzymes was measured spectrophotometrically at $340 \mathrm{~nm}$. Crude extracts of cellulase, chitinase, Trichoderma lysate and laminarinase were found to be contaminated with proteases (Table 4) - a result that appears to be in contradiction to the discussion above that addition of the lytic enzyme might have helped to protect laccase activities against proteolytic degradation. If not in the buffer, it is possible that protease activity resides in the cell walls and that addition of lytic enzymes helps to free laccase into the buffer away from stronger proteolytic attack.

Table 4. Protease activity present in crude enzyme extracts of cellulase, chitinase Trichoderma lysate and laminarinase. The protease activity was spectrophotometrically determined at $\mathrm{A}_{340}$ after incubation of the enzyme extract sample for $30 \mathrm{~min}$ with $3 \%$ azocasein as substrate at 37 ${ }^{\circ} \mathrm{C}$.

\begin{tabular}{lc}
\hline Enzyme mixture & Protease activity measured as increase in absorbance* \\
\hline Blank & $0.0002 \pm 0.07$ \\
Cellulase $(6 \mathrm{mg} / \mathrm{ml})$ & $0.0042 \pm 0.04$ \\
Chitinase $(6 \mathrm{mg} / \mathrm{ml})$ & $0.0064 \pm 0.02$ \\
Trichoderma $1 \mathrm{ysate}(6 \mathrm{mg} / \mathrm{ml})$ & $0.3410 \pm 0.13$ \\
Laminarinase $(6 \mathrm{mg} / \mathrm{ml})$ & $0.0103 \pm 0.05$
\end{tabular}

* Values are averages from two parallel measurements. 
Highest protease contamination was measured in Trichoderma lysate followed by laminarinase (Table 4).

Several protease inhibitors in different concentrations either alone or in combination were used to inhibit the total protease activity in the Trichoderma lysate cocktail obtained from Trichoderma harzianum (Table 5).

Table 5. Protease inhibitor concentration added to the crude enzyme of Trichoderma lysate and left amount of protease activity present in the sample after $15 \mathrm{~min}$ incubation at $24^{\circ} \mathrm{C}$ (several other combinations were also tested, data not shown).*

\begin{tabular}{lc}
\hline $\begin{array}{c}\text { Name of inhibitor and their concentrations used along } \\
\text { with their combinations }\end{array}$ & $\begin{array}{c}\text { Left protease activity after } \\
\text { treatment with inhibitor }\end{array}$ \\
\hline $1 \mathrm{mM}$ PMSF & $57.6 \%$ \\
$5 \mathrm{mM}$ PMSF & $73.5 \%$ \\
$1 \mathrm{mM}$ EDTA & $64.6 \%$ \\
$5 \mathrm{mM}$ EDTA & $72.2 \%$ \\
$1 \mu \mathrm{l}$ protease inhibitor cocktail & $92.8 \%$ \\
$5 \mathrm{mM}$ PMSF $+5 \mathrm{mM}$ EDTA & $14.0 \%$ \\
$5 \mathrm{mM}$ PMSF $+5 \mathrm{mM}$ EDTA $+50 \mu \mathrm{g}$ soyabean inhibitor cocktail & $9.2 \%$ \\
$5 \mathrm{mM}$ PMSF $+5 \mathrm{mM}$ EDTA $+50 \mu$ M aprotinin & $2.8 \%$ \\
$5 \mathrm{mM}$ PMSF $+5 \mathrm{mM}$ EDTA $+50 \mu$ M aprotinin & $3.4 \%$ \\
$5 \mathrm{mM}$ PMSF $+5 \mathrm{mM}$ EDTA $+5 \mu$ protease inhibitor cocktail & $0.24 \pm 0.4 \%$ \\
$5 \mathrm{mM}$ PMSF $+5 \mu 1$ protease inhibitor cocktail & $0.43 \pm 0.9 \%$ \\
$1 \mathrm{mM}$ PMSF $+5 \mu 1$ protease inhibitor cocktail & $1.05 \pm 1.9 \%$ \\
\hline Two parallel measurements were done per treatment and compared to an average values of two parallel \\
performed controls without any additives.
\end{tabular}

Although the combination of $5 \mathrm{mM}$ PMSF, $1 \mathrm{mM}$ EDTA and $5 \mu$ of protease inhibitor cocktail inhibited $99.76 \pm 0.4$ of protease activity present in Trichoderma lysate - still, this combination was not used further since EDTA has been reported to kill laccase activity (chapter 4). Alternatively, using $5 \mathrm{mM}$ PMSF with $5 \mu \mathrm{l}$ of protease inhibitor cocktail gave $99.57 \pm 0.9$ protease inhibition as measured at $\mathrm{A}_{380}$ (Table 5).

\subsubsection{Effect of protease inhibitors on laccase activity}

To elucidate effects of protease inhibitors on laccase activities, aliquots of the supernatant (100 $\mu \mathrm{l}$ each) from a new $14 \mathrm{~d}$-old 2,5-xylidine-induced culture T. versicolor culture and from cell walls of this culture $(20 \mathrm{mg}$ wet weight in $1.0 \mathrm{ml}$ of $100 \mathrm{mM}$ sodium acetate buffer, $\mathrm{pH} 5.8$ ) were treated with the two combinations of protease 
inhibitors. In case of cell walls, to some of the samples lytic enzymes (either chitinase, cellulose, or Trichoderma lysate) were also added.

Compared to non-treated controls, after $24 \mathrm{~h}$ incubation at $24^{\circ} \mathrm{C}$ a considerable loss of laccase activity was observed in supernatant (about 23\% loss of the activity present in the control samples; see Table 6) as well as the cell wall samples (Fig. 2).

Table 6. Effect of selected protease inhibitors on 2,5-xylidine induced, raw T. versicolor laccase activity in a culture supernatant from day 14 of cultivation after $24 \mathrm{hrs}$ of incubation at $24^{\circ} \mathrm{C}^{*}$.

\begin{tabular}{|c|c|}
\hline $\begin{array}{c}\text { Sample (2,5-xylidine induced culture supernatant in } 100 \\
\text { mM sodium acetate buffer pH 5.8) }\end{array}$ & $\begin{array}{c}\text { Laccase activity }(\mathrm{mU} / \mathrm{ml}) \\
\text { after } 24 \mathrm{~h} \text { incubation at } 24^{\circ} \\
\text { C }\end{array}$ \\
\hline Control without any inhibitor after incubation & $487.0 \pm 6.5$ \\
\hline $5 \mathrm{mM}$ PMSF $+1 \mathrm{mM}$ EDTA $+5 \mu 1$ protease inhibitor cocktail & $\begin{array}{c}375.2 \pm 6.9 \\
\text { (77.0\% of the activity of the } \\
\text { untreated control) }\end{array}$ \\
\hline $5 \mathrm{mM}$ PMSF $+5 \mu \mathrm{l}$ protease inhibitor cocktail & $\begin{array}{c}375.9 \pm 7.6 \\
\text { (77.1\% of the activity of the } \\
\text { untreated control) }\end{array}$ \\
\hline
\end{tabular}

After $24 \mathrm{~h}$ incubation, in the $5 \mathrm{mM}$ PMSF, $5 \mathrm{mM}+5 \mu$ protease inhibitor cocktailtreated cell wall sample $32.0 \pm 6.7 \%$, in the chitinase $+5 \mathrm{mM} \mathrm{PMSF}, 5 \mathrm{mM}+5 \mu \mathrm{l}$ protease inhibitor cocktail-treated sample $31.3 \pm 4.6 \%$, in the cellulose $+5 \mathrm{mM} \mathrm{PMSF}, 5$ $\mathrm{mM}+5 \mu \mathrm{l}$ protease inhibitor cocktail-treated sample $37.6 \pm 11.0 \%$ and in the Trichoderma lysate $+5 \mathrm{mM}$ PMSF, $5 \mathrm{mM}+5 \mu 1$ protease inhibitor cocktail-treated sample $38.4 \pm 3.1 \%$ of the laccase activity was found in the cell walls as compared to those of the controls without any inhibitor (Fig. 2). Thus, in cell wall samples nontreated with enzymes, addition of protease inhibitor lead to a loss of $68.0 \%$ of the activity in the cell walls after $24 \mathrm{~h}$ as compared to the controls without protease inhibitor. Likewise, addition of protease inhibitors caused after $24 \mathrm{~h}$ incubation a loss of $68.7 \%$ laccase activity in the cell walls in the chitinase-treated samples, a loss of $62.4 \%$ laccase activity in the cell walls in the cellulose-treated samples, and a loss of $61.6 \%$ laccase activity in the cell walls in the Trichoderma lysate-treated samples. Notably in the samples with cell walls and added enzymes, no significant difference in laccase activity 
in the buffer were observed in this series of experiments as compared to the control (see Fig. 2).

Altogether from these results, it was clear that the protease inhibitors reduced the laccase activity and were more detrimental than the presence of proteases in the sample. Therefore, protease inhibitors were not used for further experiments.

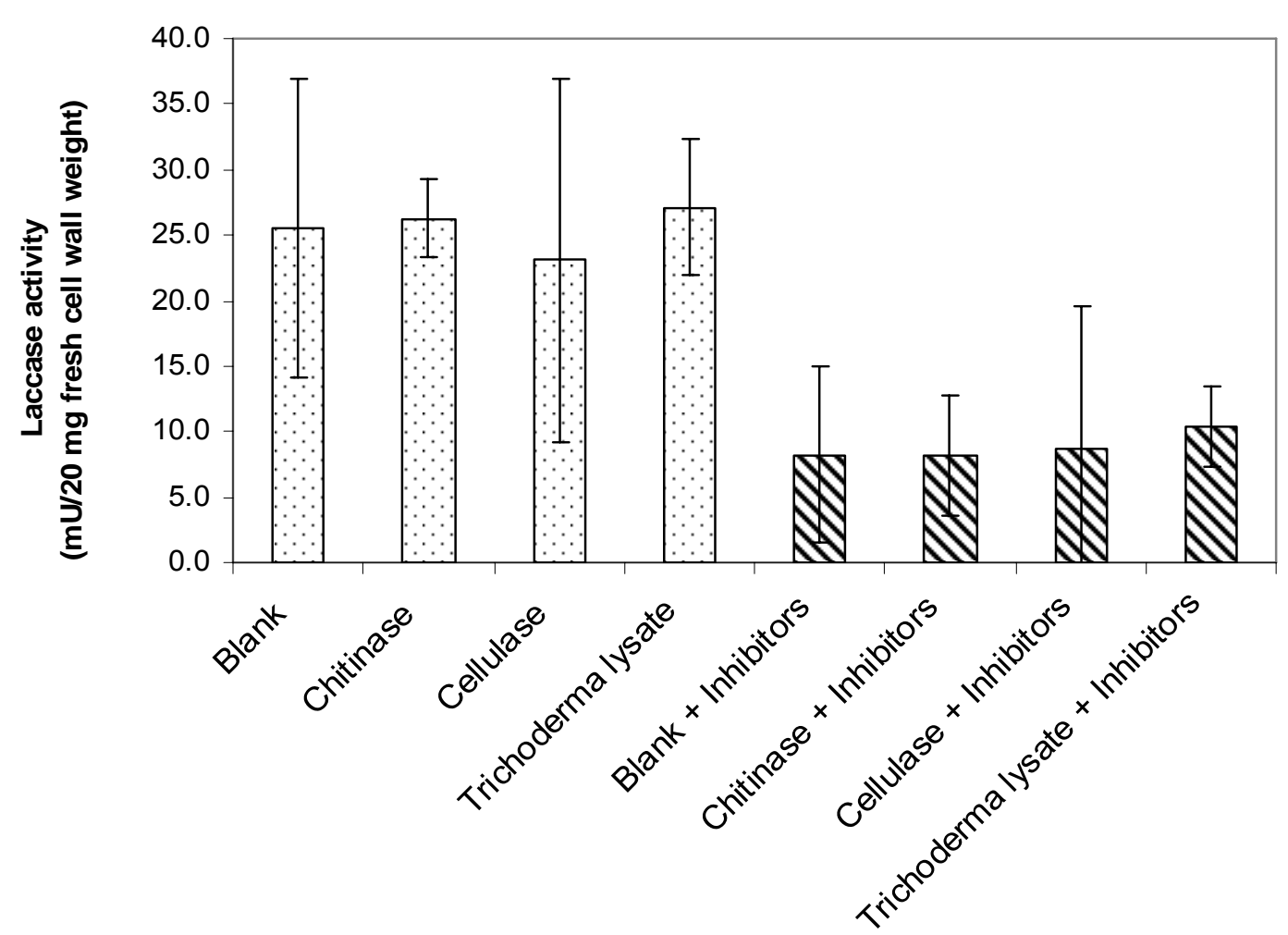

Fig. 2. Effect of protease inhibitors ( $5 \mathrm{mM}$ PMSF $5 \mathrm{mM}+5 \mu$ l protease inhibitor cocktail) on the cell wall-associated laccase activity in presence of different hydrolytic enzymes (used in concentration of 0.6 $\mathrm{mg} / \mathrm{mg}$ dry weight of cell wall). The experiment was performed with $20 \mathrm{mg}$ fresh weight of cell wall sample in $1.0 \mathrm{ml}$ of $100 \mathrm{mM}$ sodium acetate buffer, $\mathrm{pH} 5.8$ for $24 \mathrm{hrs}$ at $24^{\circ} \mathrm{C}$ in a $1.5 \mathrm{ml}$ plastic microtube. Each two measurements were performed per sample type. Blank = cell walls without addition of any enzymes. Note that the overall laccase activity in the cell walls used in this experiment was higher than that in the cell walls used in the experiments presented in Tables 1 to 3 . The original laccase activity was however not determined for the cell walls used here.

\subsubsection{Effects of higher cell wall sample amounts and different shaking parameters}

The above described experiments (Table 2, Table 3) performed in order to release laccase from cell walls were done with $20 \mathrm{mg}$ cell wall samples in a volume of $1000 \mu \mathrm{l}$ in standing $1.5 \mathrm{ml}$ plastic microtubes. In the following, different buffer volumes along with 
varying amounts of cell wall samples were used in two different kinds of shakers to release cell wall associated laccase. Cellulase was choosen an a lytic enzyme as in experiments before highest laccase activities in buffer were observed with addition of it at a $1: 0.6$ biomass/enzyme $(\mathrm{w} / \mathrm{w})$ ratio, i.e. $0.6 \mathrm{mg}$ enzyme $/ \mathrm{mg}$ dry weight of cell walls (Table 2).

The results (Table 7) showed that a ratio of cell wall (wet weight) versus buffer of 100 $\mathrm{mg}: 1 \mathrm{ml}$ in a $1.5 \mathrm{ml}$ plastic microtube is acting in extracting laccase from the cell wall samples under addition of cellulose in the same ratio as used before for $20 \mathrm{mg}$ cell walls (wet weight Table 2 and). However, the total laccase activity yield in the buffer was lower with higher amounts of cell walls $(100 \mathrm{mg})$ in the tubes $(21.3 \%$ as compared to $42.7 \%$ of initial activity, compared Table 7 and Table 2).

Table 7. Combinations of cell wall amount, buffer volume and shaking pattern used to release cell wall associated laccase by incubation the samples for $24 \mathrm{hrs}$ at $24^{\circ} \mathrm{C}$ in $100 \mathrm{mM}$ sodium acetate buffer, pH5.8.

\begin{tabular}{|c|c|c|c|c|c|}
\hline $\begin{array}{c}\text { Cell wall } \\
\text { wet } \\
\text { weight } \\
\text { (mg)* }\end{array}$ & $\begin{array}{c}\text { Buffer } \\
\text { volume } \\
(\mathrm{ml})\end{array}$ & $\begin{array}{l}\text { Cellulase } \\
\text { amount } \\
\text { added in } \\
(\mathrm{mg})^{* *}\end{array}$ & $\begin{array}{c}\text { Type of shaker } \\
\text { used } \\
\text { (rpm) }\end{array}$ & $\begin{array}{l}\text { Tributyl- } \\
\text { phosphine } \\
\text { (TBP) } \\
\text { treatment }\end{array}$ & $\begin{array}{l}\text { Laccase activity } \\
\text { in buffer at the } \\
\text { end of the } \\
\text { experiment } \\
(\mathrm{mU} / \mathrm{ml}) * * *\end{array}$ \\
\hline 1000 & 10.0 & 78.0 & $\begin{array}{l}\text { Rotary shaker } \\
\text { (100 rpm) }\end{array}$ & - & 0.00 \\
\hline 100 & 1.0 & 7.8 & $\begin{array}{l}\text { Rotary shaker } \\
\text { (100 rpm) }\end{array}$ & - & 0.00 \\
\hline 1000 & 10.0 & 78.0 & $\begin{array}{l}\text { Horizontal shaker } \\
\quad(100 \mathrm{rpm})\end{array}$ & - & 0.00 \\
\hline 100 & 1.0 & 7.8 & $\begin{array}{l}\text { Horizontal shaker } \\
\qquad(100 \mathrm{rpm})\end{array}$ & - & $\begin{array}{c}11.4 \pm 2.1 \\
\text { (21.30\% of initial } \\
\text { activity) }\end{array}$ \\
\hline 100 & 1.0 & 7.8 & $\begin{array}{l}\text { Horizontal shaker } \\
\quad(100 \mathrm{rpm})\end{array}$ & $0.5 \mathrm{mM}$ & $\begin{array}{c}15.8 \pm 1.7 \\
\text { (29.53\% of initial } \\
\text { activity) }\end{array}$ \\
\hline \multicolumn{6}{|c|}{$\begin{array}{l}\text { * Initial activity was } 53.5 \pm 0.07 \mathrm{mU} / 100 \mathrm{mg} \text { cell walls (activities within the cell walls stored frozen at }- \\
20^{\circ} \mathrm{C} \text { before further use was not retested upon defrosting aliquots for this experiment). For } 1000 \mathrm{mg} \text { wet } \\
\text { weight of cell walls, samples were incubated in } 15 \mathrm{ml} \text { tubes, for } 100 \mathrm{mg} \text { of wet weight of cell walls, } \\
\text { experiments were performed in } 1.5 \mathrm{ml} \text { plastic tubes. Cell wall material was from the same experiments as } \\
\text { described in Tables } 2 \text { and } 3 \text {. } \\
* 1: 0.6 \text { biomass } / \text { enzyme (w/w) ratio: i.e. } 0.6 \mathrm{mg} \text { enzyme } / \mathrm{mg} \text { dry weight of cell walls. } \\
* * * \text { Average values were calculated from two different measurements per sample type. }\end{array}$} \\
\hline
\end{tabular}


Shaking of cell wall samples in a rotary shaker $(100 \mathrm{rpm})$ at a ratio of $100 \mathrm{mg}$ cell wall : $1 \mathrm{ml}$ buffer and in the presence $7.8 \mathrm{mg} / \mathrm{ml}$ of cellulose did not result in amounts of laccase in the buffer (performed in duplicates). Neither, laccase activity was found when using ten times increased amounts of cell walls in $10 \mathrm{ml}$ buffer in $15 \mathrm{ml}$ plastic tubes either on a rotary or a horizontal shaker (Table 7). The reasons for these results, amongst e.g. clumping of cell wall material through the shaking hindering diffusion from the cell walls, were not further investigated. However, when $1.5 \mathrm{ml}$ plastic microtubes with a smaller amount of $100 \mathrm{mg}$ cell walls (wet weight) and buffer were treated in a horizontal shaker $(100 \mathrm{rpm})$ in presence of $7.2 \mathrm{mg}$ of cellulose $(0.6 \mathrm{mg}$ enzyme $/ \mathrm{mg}$ dry weight of cell walls, same as Table 2), $11.4 \pm 2.1 \mathrm{mU}$ of laccase from $100 \mathrm{mg}$ of mycelial wet weight was released (i.e. $21.30 \%$ of initial laccase activity). In comparison, the release was somewhat enhanced to $8.23 \%$ after the addition of $0.5 \mathrm{mM}$ TBP (a reducing agent) to the sample. $29.53 \%$ of the initial activity was found in the buffer after $24 \mathrm{~h}$ incubation in these samples (Table 7).

\subsubsection{A scaled up method for release of laccase from cell walls and identification by ESI-LC-MS}

In the following, an upscaled process is described performed in order to get a large amount of purified laccase by treating in parallel each $100 \mathrm{mg}$ wet weight of cell walls purified from a new 2,5-xylidine-treated T. versicolor culture in $501.5 \mathrm{ml}$ plastic micro tubes sequentially first with cellulase for $24 \mathrm{~h}$ on a horizontal shaker at $100 \mathrm{rpm}$, followed by a similar $24 \mathrm{~h}$ treatment with chitinase and a similar $24 \mathrm{~h}$ treatment with Trichoderma lysate (Table 8). The parallel controls contained only cell wall fraction but they did not contain any enzyme. Upon each incubation, the cell walls were centrifuged for 10 seconds at $10,000 \mathrm{~g}$ and the supernatants in the respective tubes were transferred and combined into a $50 \mathrm{ml}$ plastic tube. During the three different incubations, it was noticed that cell wall samples became slimy so that not all buffer could be taken off with a pipette. In samples with lytic enzymes, cell walls became generally more slimy than the cell walls in the control samples why after the third treatment with Trichoderma lysate the total harvested buffer volume was lower than that harvested from the controls. 
In every of the three successive steps of laccase release, the enzyme-treated samples performed generally slightly better than the control samples (Table 8). At the end of the experiment, in total $4.71 \mathrm{U}$ of laccase were obtained from the control samples and $6.83 \mathrm{U}$ from the enzyme-treated samples (Table 8).

Table 8. Total release of laccase after parallel treatment of $50 \times 100 \mathrm{mg}$ purified cell wall samples of fresh 2,5-xylidine induced T. versicolor cultures by consecutive enzymes hydrolysis in comparison to $50 \times 100 \mathrm{mg}$ purified cell wall samples of 2,5-xylidine induced $T$. versicolor cultures without enzyme.*

\begin{tabular}{cccc}
\hline Enzyme treatment** & $\begin{array}{c}\text { Released } \\
\text { laccase } \\
(\mathrm{mU} / \mathrm{ml})^{* * *}\end{array}$ & $\begin{array}{c}\text { Total } \\
\text { volume } \\
(\mathrm{ml})^{* * * *}\end{array}$ & $\begin{array}{c}\text { Total laccase activity } \\
\text { in buffer at the end of } \\
\text { the experiment }(\mathrm{mU})\end{array}$ \\
\hline
\end{tabular}

$1^{\text {st }}$ treatment for $24 \mathrm{hrs}$ at room temperature

Control for cellulase treatment

$77.5 \pm 3.7$

40.0

3100

Cellulase treatment

$94.8 \pm 7.3$

40.0

3792

(122.3\% of activity in the control sample)

$2^{\text {nd }}$ treatment for $24 \mathrm{hrs}$ at room temperature

Control for chitinase treatment

$28.4 \pm 1.8$

40.0

1130

Chitinase treatment

$45.3 \pm 3.0$

40.0

1810

(160.1\% of activity in the control sample)

$3^{\text {rd }}$ treatment for $24 \mathrm{hrs}$ at room temperature

Control for Trichoderma lysate treatment

$13.7 \pm 2.0$

35.0

Trichoderma lysate treatment

$35.3 \pm 24.0$

24.0

(256.2\% of activity in the control sample)

Total enzymatic activity released from the cell walls

Control

Enzyme treated samples

( $145.0 \%$ of activity in the control sample)

* The initial laccase activity of this preparation of cell walls was not measured.

**After each treatment, plastic microtubes were centrifuged at $10,000 \mathrm{~g}$ for 10 seconds. Supernatant containing enzyme activities were pooled together and the cell wall pellet was again used for the next treatment.

*** Average values and standard deviations were calculated from laccase activity measurements with ABTS from of three parallel aliquots of the liquids collected from the 50 respective samples.

**** $1000 \mu \mathrm{l}$ of sodium acetate buffer, $\mathrm{pH} 5.8$ was added per sample pre treatment. However, whereas $800 \mu \mathrm{l}$ buffer was harvested after the first incubation both from sample with and samples without cellulose and after the second incubation both from sample with and samples without chitinase, after the third incubation only $700 \mu \mathrm{l}$ were taken from control samples and $480 \mu 1$ from samples treated with Trichoderma lysate. 
Released cell wall laccase samples obtained after the treatment of different hydrolytic enzymes were separated on a native gel. In-gel staining resulted in two bands corresponding to phenoloxidase activity in all cell wall samples (lane 2-5, Fig. 3). However, the supernatant sample resulted in only one laccase band (lane 1, Fig. 3), corresponding in migration in the gels to the lower of the two bands obtained from cell wall samples (Fig. 3). Interesting is further that the upper laccase band in the enzymetreated samples run differently in the gel than the upper band from the cell wall samples untreated with lytic enzymes (Fig. 3). The reason for this is not known. It might be another enzyme, more easy to diffuse than the enzymes found in the samples treated with lytic enzymes. Moreover, it could be that the increased laccase activity found in several of the above described experiments in the buffer of enzyme-treated samples is due to another set of enzymes, i.e. there might be a differential release of cell wall bound activity in presence and in absence of lytic enzymes.

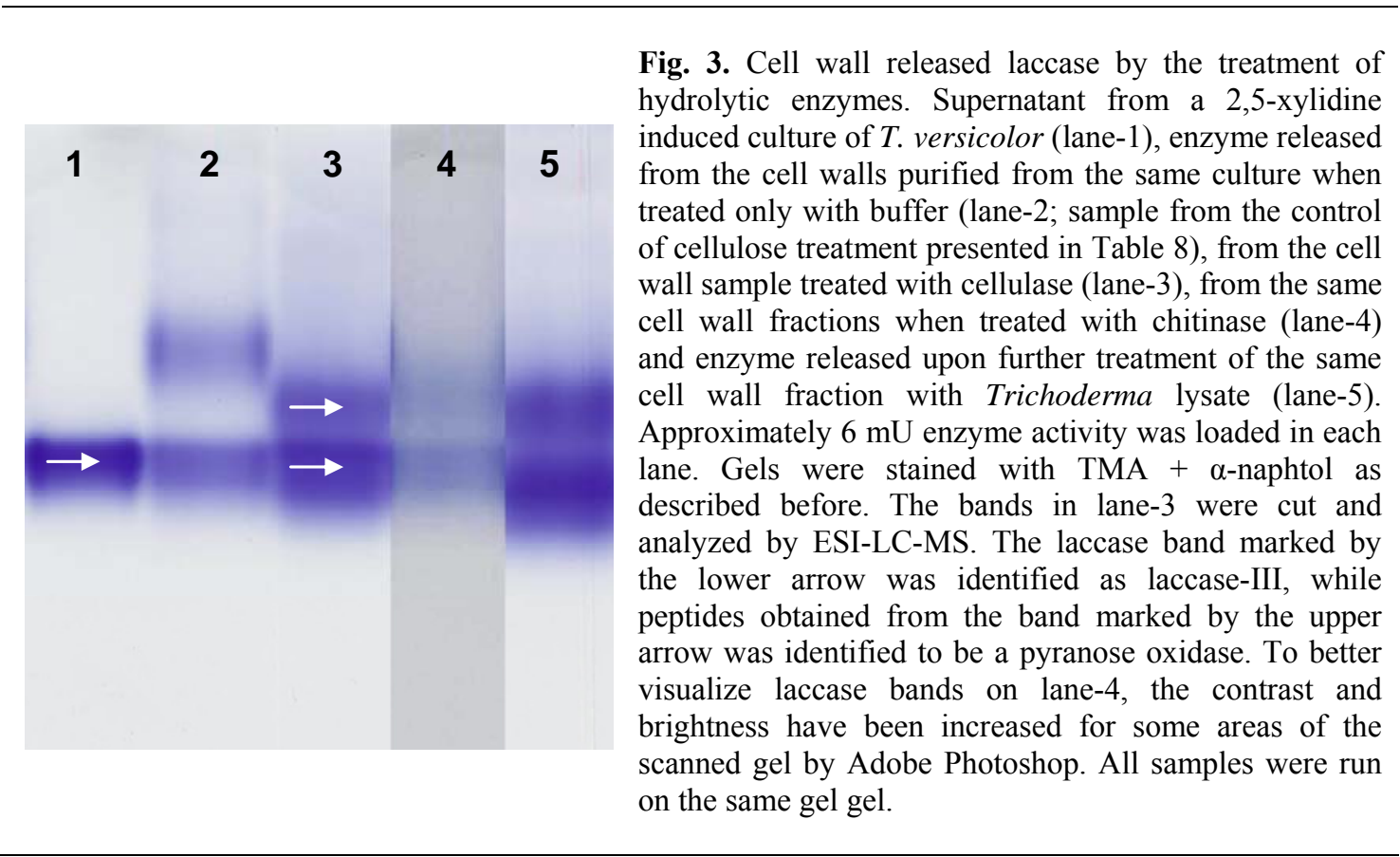

Enzyme stained bands, obtained after the $1^{\text {st }}$ cellulose treatment of cell wall samples (lane 3), were cut from a corresponding Coomassie stained gel, trypsin-digested and analyzed by ESI-LC-MS. The cell wall released phenoloxidase from the lower band of 
lane 3 (Fig. 3) was identified as the already known laccase-III with a score of 141 and peptide coverage of $20 \%$. The 2,5-xylidine induced purified supernatant laccase represented by an arrow in lane-1 (Fig. 3), was described before already as Laccase-III with a significant score of 240 and sequence coverage of 13\% (chapter 4 ). The upper band from lane-3 (Fig. 3) resulted in a hit for a pyranose oxidase of T. versicolor with a score of 176 and peptide coverage of 9\% (Table 9). Pyranose oxidase is an enzyme producing $\mathrm{H}_{2} \mathrm{O}_{2}$ needed for peroxidase activity and possibly directly associated with peroxidases and that has been reported to reside at least in the white-rot fungi Phanerochaete and Oudemannsiella in membraneous material, in the periplasmic hyphal space as well as extracellular in lignocellulosic substrate. In T. versicolor, parallel high level of laccase and pyranose oxidase in degradation of wood has been reported (Daniel at el 1994b; Nishimura et al. 1996).

Table 9. Identification of enzymes released from cell wall samples purified from $T$. versicolor mycelium obtained from a 2,5-xylidine induced culture as shown in Fig. 3 (bands from lane 3 as marked by arrow were excised and analyzed by ESI-LC-MS):

\begin{tabular}{|c|c|c|c|c|c|c|c|}
\hline $\begin{array}{l}\text { Sample } \\
\text { protein }\end{array}$ & $\begin{array}{c}\text { Peptides identified by ESI-LC- } \\
\text { MS }\end{array}$ & $\begin{array}{l}\text { Peptide } \\
\text { score }\end{array}$ & $\begin{array}{c}\text { Protein } \\
\text { identification }\end{array}$ & $\begin{array}{l}\text { Total } \\
\text { score }\end{array}$ & $\begin{array}{c}\text { Coverage } \\
\%\end{array}$ & pI & $\begin{array}{l}\text { MW } \\
\text { kDa }\end{array}$ \\
\hline $\begin{array}{l}\text { Lane } 3 \\
\text { from Fig. } \\
\text { 3, upper } \\
\text { band }\end{array}$ & $\begin{array}{l}\text { LIVDWR } \\
\text { VAMFDIGEIDSGLK } \\
\text { YDVVIVGSGPIGCTYAR } \\
\text { MGFDEQEDNCCVDTDSR }\end{array}$ & $\begin{array}{l}42 \\
48 \\
24 \\
47\end{array}$ & $\begin{array}{l}\text { Pyranose } \\
\text { oxidase } \\
\text { (NCBI } \\
\text { Accession } \\
\text { number: } \\
\text { Q5G234) } \\
\end{array}$ & 176 & 9 & 5.23 & 69 \\
\hline $\begin{array}{l}\text { Lane } 3 \\
\text { from Fig. } \\
3 \text {, lower } \\
\text { band }\end{array}$ & $\begin{array}{l}\text { STSIHWHGFFQK } \\
\text { SAGSTVYNYDNPIFR } \\
\text { SPSTTTADLTVISVTPGKR } \\
\text { ANPSFGNVGFTGGINSAILR }\end{array}$ & $\begin{array}{l}36 \\
56 \\
85 \\
49\end{array}$ & $\begin{array}{l}\text { Laccase-III } \\
\text { (NCBI } \\
\text { accession } \\
\text { number: } \\
\text { CAA77015) }\end{array}$ & 138 & 20 & 4.8 & 55 \\
\hline
\end{tabular}

\subsubsection{Comparision of total laccase activities in the supernatant and in cell walls of 2,5-}

\section{xylidine-induced T. versicolor cultures}

Summing up the results for the distribution of laccase in supernatant and cell wall samples of 2,5-xylidine-induced T. versicolor cultures resulted in the following facts: a total of 157.76 units of supernatant laccase (69.60\% of the whole culture) was measured in $96 \mathrm{ml}$ of BSM media plus 62.68 units $(27.8 . \%$ of the whole culture) that was washed 
away from the mycelium (Table 10). From the same flask, $2.1 \mathrm{~g}$ fresh weight of mycelia was harvested, which contained 5.74 units of laccase activity. After sequential treatment of the cell wall fractions with hydrolytic enzymes, a total of 2.12 units of laccase activity was released, i.e. $0.94 \%$ of the total laccase activity of whole culture. $2.55 \%$ of the total laccase activity of the culture was present in mycelium-bound form (Table 10).

The ratio of total supernatant volume $(96 \mathrm{ml})$ and laccase activity $(156.76 \mathrm{U})$ was 1 : 1.62. On the other hand, the total weight of mycelia $(2.1 \mathrm{~g})$ and total laccase activity associated to the mycelia $(5.74 \mathrm{U})$ resulted a ratio of $1: 2.73$. This means that a higher laccase density is associated to the mycelia. From these results, it might be concluded that in wood degradation by $T$. versicolor, a higher amount of substrate degradation is possible directly at the mycelia, in particular also, as other results in this thesis (chapter 4) indicated that the immobilized form of the enzyme is more stable.

Table 10. Comparison of laccase activity in supernatant, cell wall and cell wall released laccase after different enzyme treatment (cellulase, chitinase and Trichoderma lysate) from 2,5-xylidine induced 14 days-old cultures of Trametes versicolor.

\begin{tabular}{|c|c|c|c|}
\hline Laccase activity from & $\begin{array}{l}\text { Sample } \\
\text { amount }\end{array}$ & $\begin{array}{c}\text { Total } \\
\text { laccase } \\
\text { activity }(\mathbf{U})\end{array}$ & $\begin{array}{c}\text { \% laccase activity } \\
\text { compared to the total } \\
\text { mycelia from one flask }\end{array}$ \\
\hline Supernatant & $96(\mathrm{ml})$ & 156.76 & $69.60 \%$ \\
\hline $\begin{array}{l}\text { Buffer (1st wash of mycelium after } \\
\text { homogenization) }\end{array}$ & $100(\mathrm{ml})$ & 62.68 & $27.85 \%$ \\
\hline Free laccase in total & & 219.35 & $97.45 \%$ \\
\hline Total mycelia after 5 washes* & $2.1(\mathrm{~g})$ & 5.74 & $2.55 \%$ \\
\hline After cellulase treatment* & $2.1(\mathrm{~g})$ & 0.69 & $0.31 \%$ \\
\hline After chitinase treatment* & $2.1(\mathrm{~g})$ & 0.68 & $0.30 \%$ \\
\hline After Trichoderma lysate treatment* & $2.1(\mathrm{~g})$ & 0.75 & $0.33 \%$ \\
\hline Sum of all enzyme treatments* & $2.1(\mathrm{~g})$ & 2.12 & $0.94 \%$ \\
\hline $\begin{array}{l}\text { Total laccase activity of whole culture } \\
\text { (free and bound laccase activity) }\end{array}$ & & 225.1 & $100 \%$ \\
\hline
\end{tabular}

* Data from Table 8 


\subsubsection{Conclusion}

In this study, an efficient method for the release of laccase from the cell wall of $T$. versicolor was to be established. The release was found to be dependent on several parameters including the amount of cell wall, type of container, amount of hydrolytic enzyme(s), contamination of these by proteases, shaking pattern, time of incubation and usage of reducing agents. The results from the different experiments however were variable which did not allow a definitive conclusion, whether treatment with lytic enzyme will always beneficial and if, whether cellulase or Tricholoma lysate has better effects. Cellulase often gave the highest activity of enzyme in the buffer, Tricholoma lysate reduced activity more in the cell walls than cellulase.

Finally on a larger scale, the cell wall associated laccase was released by the sequential extraction with different hydrolytic enzymes. ESI-LC-MS analysis of the released enzymes after cellulase treatment identified one of two phenol-oxidase active bands in protein gels as the laccase III of $T$. versicolor already reported before to be present in the culture supernatant (see chapter 4) whereas pyranose oxidase was identified in the other band as an additional secreted enzyme with a function in lignocellulose degradation .

\subsection{References}

Barrasa J.M., Gutierrez. A., Escaso. V., Guillen. F., Martinez M.J., and Martinez A.T. (1998). Electron and fluorescence microscopy of extracellular glucan and aryl-alcohol oxidase during wheat-straw degradation by Pleurotus eryngii. Applied and Environmental Microbiology 64: $325-332$

Cai Y.J., Chapman S.J., Buswell J.A., and Chang S.T. (1999). Production and distribution of endoglucanase, cellobiohydrolase, and B-glucosidase components of the cellulolytic system of Volvariella volvacea, the edible straw mushroom. Applied and Environmental Microbiology 65:553-559.

Candiano G., Bruschi M., Musante L., Santucci L., Ghiggeri G.M., Carnemolla B., Orecchia P., Zardi L., and Righetti P.G. (2004). Blue silver: A very sensitive colloidal Coomassie G-250 staining for proteome analysis. Electrophoresis 25:1327-1333.

Carlile A.J., Bindschedler L.V., Bailey A.M., Bowyer P., Clarkson J.M., and Cooper R.M. (2000). Characterization of SNP1, a cell wall-degrading trypsin, produced during infection by Stagonospora nodorum. Molecular Plant Microbe Interactions 13:538-550. 
Cherniak R., Morris L.C., Meyer S.A., and Mitchell T.B. (1993). Glucuronoxylomannan of Cryptococcus neoformans obtained from patients with AIDS. Carbohydrate Research 249:405-413.

Curragh H.J., Mooibroek H., Wessels J.G.H., Marchant R., and Mullan E. (1992). Protoplast formation and DNA-mediated transformation of Fusarium culmorum to hygromycin B resistance. Mycological Research 97:313-317.

Daniel G. (1994a). Use of electron microscopy for aiding our understanding of wood biodegradation. FEMS Microbiology Reviews 13:199-233.

Daniel G., Volc J., and Kubatova E. (1994b). Pyranose Oxidase, a major source of $\mathrm{H}_{2} \mathrm{O}_{2}$ during wood degradation by Phanerochaete chrysosporium, Trametes versicolor, and Oudemansiella mucida. Applied and Environmental Microbiology 60(7): 2524-2532.

Farina J.I., Molina O.E., and Figueroa L.I.C. (2004). Formation and regeneration of protoplasts in Sclerotium rolfsii ATCC 201126. Journal of Applied Microbiology 96:254-262.

Havlis J., Thomas H., Sebela M., and Shevchenko A. (2003). Fast-response proteomics by accelerated in-gel digestion of proteins. Analytical Chemistry 75:1300-1306.

Hüttermann A., and Volger C. (1973). Induction of aryl beta glucosidase in Fomes annosus by cellobiose. Archiv fur Mikrobiologie 93:195-204.

Johannes C., and Majcherczyk A. (2000). Laccase activity tests and laccase inhibitors. Journal of Biotechnology 78: 193-199.

Latgé J.P., and Calderone R. (2006). The fungal cell wall. In: The Mycota, Growth, Differentiation and Sexuality Vol. I, $\mathbf{2}^{\text {nd }}$ edition (Kües and Fischer eds.), Springer-Verlag, Heidelberg, in press.

Laemmli U.K. (1970). Cleavage of structural proteins during assembly of head of bacteriophage T4. Nature 227:680-685.

Matsumura E., Yamamoto E., Numata A., Kawano T., Shin T., and Murao S. (1986). Structures of the laccase catalyzed oxidation products of hydroxy benzoic acids in the presence of ABTS (2,2'-Azino-Di-(3-Ethylbenzothiazoline-6-Sulfonic Acid)). Agricultural and Biological Chemistry 50:1355-1357.

Mrsa V., Ecker M., Cappellaro C., Teparic R., and Tanner W. (1999). Saccharomyces cerevisiae cell wall proteins. Food Technol. Biotechnol. 37:21-27.

Nishimura I., Okada K., and Koyama Y. (1996). Cloning and expression of pyranose oxidase cDNA from Coriolus versicolor in Escherichia coli. J Biotechnol 52(1): 11-20.

Nicole M., Chamberland H., Geiger J.P., Lecours N., Valero J., Rio B., and Ouellette G.B.(1992). Immunocytochemical localization of laccase L1 in wood decayed by Rigidoporus lignosus. Applied and Environmental Microbiology 58:1727-1739. 
Orlean P. (1997). Biogenesis of yeast wall and surface components. In: The molecular and cellular biology of the yeast Saccharomyces. Cell cycle and biology (Pringle J.R., Broach J.R., Jones E.W. eds.) Chapmann and Hall, London, pp. 229-262.

Ruel K.C., and Joseleau J.P. (2003). Development of immunomicroscopic methods for bioremediation. In: The utilization of bioremediation to reduce soil contamination: Problems and solutions (Sasek et al. eds). Kluywer Academic Publishers, Dordrecht, pp. 187-197

Ruiz-Herrera J. (1992). Chemical composition of the fungal cell wall. In: Fungal Cell Wall: Structure, Synthesis and Assembly (Ruiz-Herrera J. ed.), CRC Press, Boca Raton, pp. 5-22.

Ruiz-Herrera J., Leon C.G., CarabezTrejo A., and ReyesSalinas E. (1996). Structure and chemical composition of the cell walls from the haploid yeast and mycelial forms of Ustilago maydis. Fungal Genetics and Biology 20:133-142.

Sassoon J., and Mooibroek H. (2001). A system of categorizing enzyme-cell wall associations in Agaricus bisporus, using operational criteria. Applied Microbiology and Biotechnology 56:613-622.

Sietsma J.H., and Wessels J.G.H. (2005). Apical wall biogenesis. In: The Mycota. Growth, Differentiation and Sexuality, Vol. I, 2nd edition, Kües and Fischer (eds.), Springer-Verlag, Heidelberg, in press.

Smith A.E., Zhang Z.B., Thomas C.R., Moxham K.E., and Middelberg A.P.J. (2000). The mechanical properties of Saccharomyces cerevisiae. Proceedings of the National Academy of Sciences of the United States of America 97:9871-9874.

Stauff J., and Jaenicke R. (1994). Physikalische Chemie der Lösungen. In: Biochemisches Taschenbuch-II. (Rauen H.M ed.), $\mathbf{2}^{\text {nd }}$ Edition, Springer-Verlag, Berlin Heidelberg, pp. 37121.

Tuor U., Winterhalter K., and Fiechter A. (1995). Enzymes of white rot fungi involved in lignin degradation and ecological determinants for wood decay. Journal of Biotechnology 41:1-17.

Vaishnav V.V., Bacon B.E., O'Neill M., and Cherniak R. (1998). Structural characterization of the galactoxylomannan of Cryptococcus neoformans Cap67. Carbohydrate Research 306:315-330.

Walser P.J, Velagapudi R., Aebi M., and Kües U. (2003). Extracellular matrix proteins in mushroom development. Rec. Res. Devel. Microbiol 7: 381-415.

Walser P.J., Haebel P.W., Kunzler M., Sargent D., Kües U., Aebi M., and Ban N. (2004). Structure and functional analysis of the fungal galectin CGL2. Structure 12:689-702.

Walser P.J., Kües U., Aebi M., and Kunzler M. (2005). Ligand interactions of the Coprinopsis cinerea galectins. Fungal Genetics and Biology 42:293-305. 
Wessels J.G.H., and Sietsma J.H. (1979). Wall structure and growth in Schizophyllum commune. In: Fungal wall and hyphal growth (Bentik J.N., Trinci A.P.J. eds), Cambridge University Press, pp. 27-48.

Wösten H.A.B. (2001). Hydrophobins: Multipurpose proteins. Annual Review of Microbiology 55:625-646.

Zhu X.D., Gibbons J., Garcia-Rivera J., Casadevall A., and Williamson P.R. (2001). Laccase of Cryptococcus neoformans is a cell wall-associated virulence factor. Infection and Immunity 69:5589-5596.

Zhu X.D., and Williamson P.R. (2003). A CLC-type chloride channel gene is required for laccase activity and virulence in Cryptococcus neoformans. Molecular Microbiology 50:1271-1281. 
Extracellular proteins from Trametes versicolor 



\section{Extracellular proteins from Trametes versicolor}

\subsection{Abstract}

The supernatant proteins were isolated from the liquid culture of Trametes versicolor and analyzed by 2D-gel electrophoresis. Identification of supernatant proteome using ESILC-MS resulted in detection of most of the known proteins available in MSDB (mass spectrometry database $\mathrm{ftp} / / \mathrm{ftp} . n c b i . n i h . g o v /$ repository/MSDB/msdb.nam). The cell wall proteins were solubilized from the isolated and purified cell wall fractions by hot SDS and $\beta$-mercaptoethanol treatment followed by 1,3-glucanase. 2D-PAGE analysis performed from these cell wall fractions showed a large number of non-covalent bound proteins ( $>400$ visible spots), while $>100$ visible protein spots were present in the supernatant proteome of $T$. versicolor.

\subsection{Introduction}

Extra-cellular proteins (including supernatant and the cell wall) play an important role in various functions of fungi such as formation of the cell wall, enzymatic degradation of substrates etc. Wood degrading basidiomycetes, secrete many extra-cellular proteins that may be localized in the cell wall or may be associated with a substrate. In white-rot fungi, extra-cellular enzymes like laccase, lignin peroxidase, manganese peroxidase $(\mathrm{MnP})$ are known to be involved in breakdown of growth substrate (Tuor et al. 1995; Leonowicz et al. 1999; 2001; Hofrichter 2002). Several supernatant proteins like laccase are well studied for their function and structure (Bertrand et al. 2002; Piontek et al. 2002; Xiao et al. 2003). A number of supernatant proteins e.g. lignin peroxidase, manganese peroxidase are also detected in the cell wall of some of the white-rot fungi (Ruel et al. 1991; Srebotnik et al. 1998; Rast et al. 2003). Laccase was found to be present in a higher concentration at the apical tip of the hyphae as compared to the exterior sub-apical region of hyphae (Jones et al. 1999).

Abbreviations: CWPs (cell wall proteins), CWFs (cell wall fractions), IEF (iso-electric focusing), ESI-LC-MS (Electrospray Ionization Liquid Chromatographic Tandem Mass Spectrometry), Vhr (Volt hours). 
Using immuno-gold labelling, Daniel found several redox and hydrolytic enzymes present in the cell wall of T. versicolor and other white-rots (Daniel 1994). Unlike the supernatant enzymes, at least some of the cell wall associated-enzymes are responsible for basic reactions in cell wall synthesis, while others may contribute to breakdown of growth substrates (Latgé and Calderone 2006; Sietsma and Wessels 2006). There are some well studied cell wall-associated enzymes from basidiomycetes like tyrosinase, chitin synthase, $\beta-(1-3)$-synthase, chitinase, (1-3)- $\beta$-glucanase, $\beta-\mathrm{N}$-acetylhexosaminidase. A recent review of fungal cell wall proteins was given by Rast et al. (2003). Additionally, only few cell wall proteins are well characterised in the basidiomycetes, for example, hydrophobins (Wösten 2001; Walser et al. 2003) and galectins (Walser et al. $2003 ; 2004 ; 2005)$. In comparison to the ascomycetes, much less is known about the cell wall of basidiomycetes, primarily due to the complexity of the cell wall and lack of established methods.

In the past, studies have focused on the purification, identification and characterization of individual proteins secreted from culture liquid of T. versicolor. However, studies aimed at the proteome level have not been conducted for supernatant or for cell wall associated proteins. In this study, supernatant proteins from $T$. versicolor were analyzed by $2 \mathrm{D}$ electrophoresis and ESI-LC-MS. Additionally, 2D-electrophoresis was used to separate the cell wall proteins (CWPs) solubilized from isolated cell wall fractions by hot SDS and $\beta$-mercaptoethanol treatment followed by 1,3-glucanase digestion of remaining CWF's.

\subsection{Materials and methods}

\section{Fungal cultures}

T. versicolor strain number 6 from the collection of the Institute of Forest Botany, Georg August Universität, Göttingen,were cultivated on basidiomycetes-medium (BSM, Hüttermann and Volger, 1973) with 1.5\% agar. Starter liquid cultures were prepared by inoculation of $100 \mathrm{ml} \mathrm{BSM}$ liquid medium in $500 \mathrm{ml}$ conical flasks with three agar pieces $\left(1 \mathrm{~cm}\right.$ in diameter) of the stock culture and cultivated stationary at $25^{\circ} \mathrm{C}$ in the dark. Mycelium of 14 days-old liquid cultures were gently disrupted using an Ultra- 
Turrax T25 (rod diameter $10 \mathrm{~mm}$; Janke \& Kunkel, IKA-Labortechnik, Germany) at 9,000 rpm for 1 minute under sterile conditions. Each $4 \mathrm{ml}$ of mycelium suspension were used to inoculate new $100 \mathrm{ml}$ BSM liquid cultures. Standing cultures of $T$. versicolor were induced after seven days of incubation with $100 \mu 10.5 \mathrm{M}$ 2,5-xylidine and incubated further for seven more days stationary at $25^{\circ} \mathrm{C}$ in the dark. The culture supernatants were harvested by vacuum filtration using filter paper (595 Round filter, $\varnothing$ 90 mm, Schleicher \& Micro Science GmbH, Germany).

\section{Laccase measurement}

Laccase activity in the liquid culture was measured using ABTS [2,2'-azino-bis(3ethylenbenzothiazoline-6-sulfonic-acid)] as substrate (Matsumura et al. 1986). One unit of laccase activity was defined as the amount of laccase that oxidize $1 \mu \mathrm{mol}$ substrate per minute.

\section{Protein extraction and quantification}

Culture supernatants were centrifuged for $20 \mathrm{~min}$ at $3,200 \mathrm{~g}$ and $4{ }^{\circ} \mathrm{C}$. Protein concentration was determined by Coomassie Plus-Bradford assay kit (Pierce, USA) using bovine serum albumin (BSA) as a standard. Proteins were precipitated from supernatant aliquots containing to $50-100 \mu \mathrm{g}$ protein.

The non-covalently bound proteins from the surface of mycelia (hyphal sheath proteins) were extracted with $2 \%$ Tween- 80 by applying $1 \mathrm{ml}$ of detergent solution to $100 \mathrm{mg}$ fresh weight of intact mycelia. The samples were mixed gently for 5 minutes, centrifuged at $10,000 \mathrm{~g}$ for 2 minutes and the supernatant was collected.

The non-covalently bound cell wall proteins from purified cell wall fractions (CWFs; for details refer chapter 1) were extracted from $10 \mathrm{mg}$ dry weight of samples by boiling the samples for $10 \mathrm{~min}$ in $1 \mathrm{ml}$ protein extraction buffer (PE-buffer; $60 \mathrm{mM}$ Tris-HCl pH 6.8, $50 \mathrm{mM}$ EDTA, 2\% SDS, 0.5\% $\beta$-mercaptoethanol; Masuoka et al. 2002). After centrifugation for $5 \mathrm{~min}$ at $10,000 \mathrm{~g}$, the supernatant was harvested and the remaining cell wall pellet was extracted three more times as described above. All four extracts were combined and the total protein amount in the samples was determined by the modified Lowry method (Peterson 1977) using bovine serum albumin (BSA) as a standard.

Covalently bound cell wall proteins were released by treating the cell wall samples with 1,3-glucanase. After extraction of non-covalently bound cell wall proteins as described 
above, $400 \mu \mathrm{l}$ of $50 \mathrm{mM}$ Tris/ $\mathrm{HCl} \mathrm{pH} 7.4,1.4 \mu 1$ ß-mercaptoethanol was added in a 1.5 $\mathrm{ml}$ plastic micro tube containing $8 \mathrm{mg}$ dried cell wall samples. To the same plastic microtube $240 \mathrm{U}$ of Quantazyme (Qbiogene, Germany) (1,3-glucanase) was added. The microtubes were gently shaken in a horizontal shaker $(100 \mathrm{rpm})$ at $37^{\circ} \mathrm{C}$ overnight and the supernatant was collected by centrifuging microtubes for 5 minutes at $10,000 \mathrm{~g}$.

Four volumes of $10 \%$ TCA in acetone (Damerval et al. 1986) along with one volume of sample were incubated at $-20^{\circ} \mathrm{C}$ overnight. Proteins were pelletted by centrifugation at 3,200 $\mathrm{g}$ for $20 \mathrm{~min}$, washed four times with acetone to remove TCA and air dried.

\section{D and 2D electrophoresis}

1D-SDS-PAGE electrophoresis was performed using 12x12 cm discontinuous $12 \%$ acrylamide gels with $0.025 \mathrm{M}$ Tris base, pH 8.3 as electrode buffer (Laemmli 1970). Protein samples were mixed in sample buffer $(0.06 \mathrm{M}$ Tris-Cl, $\mathrm{pH} 6.8,10 \%$ glycerol, $0.025 \%$ bromphenol blue). $20 \mu 1$ samples with $1 \mu \mathrm{g} / \mu 1$ protein were loaded and run at 10 $15^{\circ} \mathrm{C}$ at a constant current of $30 \mathrm{~mA}$.

For 2D-electrophoresis, protein samples were dissolved in loading buffer [8 $\mathrm{M}$ urea, 4\% (w/v) CHAPS, $50 \mathrm{mM}$ DTT, 5\% (v/v) Triton X100, 0.67\% (v/v) Ampholyte buffer (Amersham Biosciences)]. $350 \mu \mathrm{l}$ of sample solution containing approximately $100 \mu \mathrm{g}$ protein was loaded on $18 \mathrm{~cm}$ IPG-strips, $\mathrm{pH}$ range 3-10 (Amersham Biosciences) in ceramic holders, rehydrated and focused using an Ettan IPGphor isoelectric focusing machine (Amersham) for a total of $46,000 \mathrm{Vhr}$ at $15^{\circ} \mathrm{C}$ with the following settings: 100 $\mu \mathrm{A}$ per strip, (12 hr, $20 \mathrm{~V}$, step and hold), $200 \mathrm{~V}(1 \mathrm{hr}), 500 \mathrm{~V}(1 \mathrm{hr}), 1,000 \mathrm{Vhr}, 8,000$ $\operatorname{Vhr}(8,000 \mathrm{~V}), 40000 \mathrm{Vhr}(8,000 \mathrm{~V})$, all according to the protocol of the manufacture. In the $2^{\text {nd }}$ dimension, proteins were separated on $12 \%$ PAGE using Ettan DALTsix electrophoresis chamber (Amersham) together with a protein marker (Precision Protein Marker, Biorad, 10-250 kDa. After separation of the proteins at $10^{\circ} \mathrm{C}$ for $5.5 \mathrm{hr}$ (step-1: $600 \mathrm{~V}, 400 \mathrm{~mA}$ for $30 \mathrm{~min}$; step-2: $3000 \mathrm{~V}, 400 \mathrm{~mA}, 100 \mathrm{~W}$ for $5 \mathrm{hrs}$ ), the gels were fixed in $30 \%$ methanol with $12 \%$ acetic acid and $0.05 \%$ formaldehyde overnight and subsequently stained with silver (Blum et al. 1987). The improved silver staining protocol was used as described by Mortz et al. (2001). For colloidal Coomassie blue staining gels were fixed in $12 \%(\mathrm{w} / \mathrm{v})$ trichloroacetic acid (TCA) solution overnight (Candiano et al. 2004). Stained gels were scanned at 300 dpi resolution (Microtek, TMA 1600, Hannover, Germany). 


\section{Protein identification by ESI-LC-MS analysis}

Stained bands were excised from 1D gels, cut into small pieces, washed once with $200 \mu \mathrm{l}$ of distilled water for 15 minutes and $200 \mu \mathrm{l}$ of $50 \%$ methanol, and dehydrated in $200 \mu \mathrm{l}$ of pure acetonitrile for $20 \mathrm{~min}$. In-gel digestion of proteins with trypsin was performed at $58^{\circ} \mathrm{C}$ as described by Havlis et al. (2003). The resulting peptides were extracted in two steps with $200 \mu \mathrm{l}$ of $5 \%$ formic acid and $200 \mu \mathrm{l}$ of $50 \%$ acetonitrile with $5 \%$ formic acid (30 min each step). The pooled extracts were concentrated using a vacuum concentrator and peptides were dissolved in $5 \mu 1$ of $5 \%$ formic acid for ESI-LC-MS. $4 \mu 1$ of sample was analyzed by ESI-LC-MS (Esquire-3000, Bruker Daltonics, Bremen, Germany). Gel eluted peptides were injected into the Liquid Chromatography columns and the corresponding peptides were passed through a high-voltage electric path for ionization in the mass spectrometer, ESI-LC-MS (Electro Spray Ionization-Liquid Chromatographmass spectrometer; Esquire-3000, Bruker Daltonics, Bremen, Germany) for Mass Spectrometeric analysis. MS/MS spectra obtained from the ESI-MS detector were further processed by the Bruker Daltonics Data Analysis software (Interactive data processing, esquire series) and exported to the protein database and search engine Mascot (version 2.0, Matrix Science, http://www.matrixscience.com/ search form_select.html) in Mascot Generic Format (MGF). Searches were performed first against a mass spectrometery data base (MSDB) (tp://ftp.ncbi. nih.gov/repository/MSDB/msdb.nam). In addition, an own database for Mascot analysis was created (19 ${ }^{\text {th }}$ May 2005) with sequences from SNAP predictions and annotated protein sequences from the $C$. cinerea genome (Jason Stajich, Duke University, unpublished, http://genome.semo.edu/cgibin/gbrowse/coprinus) combined with the SwissProt database, the NCBI database, the annotated Phanerochaete chrysosporium proteins, and 17 laccase sequences of C. cinerea as annotated by S. Kilaru (unpublished). All cysteine residues were searched as reduced and methionine residues in the oxidized form. Mascot parameters were set to use monoisotopic masses with tolerance of 1.5 for precursor ions and 0.5 for fragment ions. 


\subsection{Result and discussion}

2D-electrophoresis protocols already described for ascomycetes could not be applied to the samples of basidiomycetes. High amount of polysaccharide content present in the culture supernatant and cell wall extracts resulted in an excessive background. Under standard conditions vertical and horizontal streaking were observed during gel electrophoresis. Therefore, before performing proteomics experiments for samples of our interest protocols for 2D-gel electrophoresis and mass spectrometry were optimized with respect of: 1) the optimal protein amount required to be loaded on the gel and 2) different staining methods to detect the maximum number visible spots on 2D-gels and to enable their trypsin digestion in compatibility with ESI-LC-MS.

About $20 \mu \mathrm{g}, 40 \mu \mathrm{g}, 70 \mu \mathrm{g}$ and $100 \mu \mathrm{g}$ of supernatant protein from cultures of T. versicolor were loaded on $18 \mathrm{~cm}$ IPG-strip pH 3-10 from Amersham and iso-electric focusing was performed for $49,700 \mathrm{Vhr}$. In preliminary experiments, possibly due to presence of excessive polysaccharide non-induced supernatant samples from $T$. versicolor resulted in vertical streaking and unsharp spots compared to 2,5-xylidineinduced gels (Fig. 1).

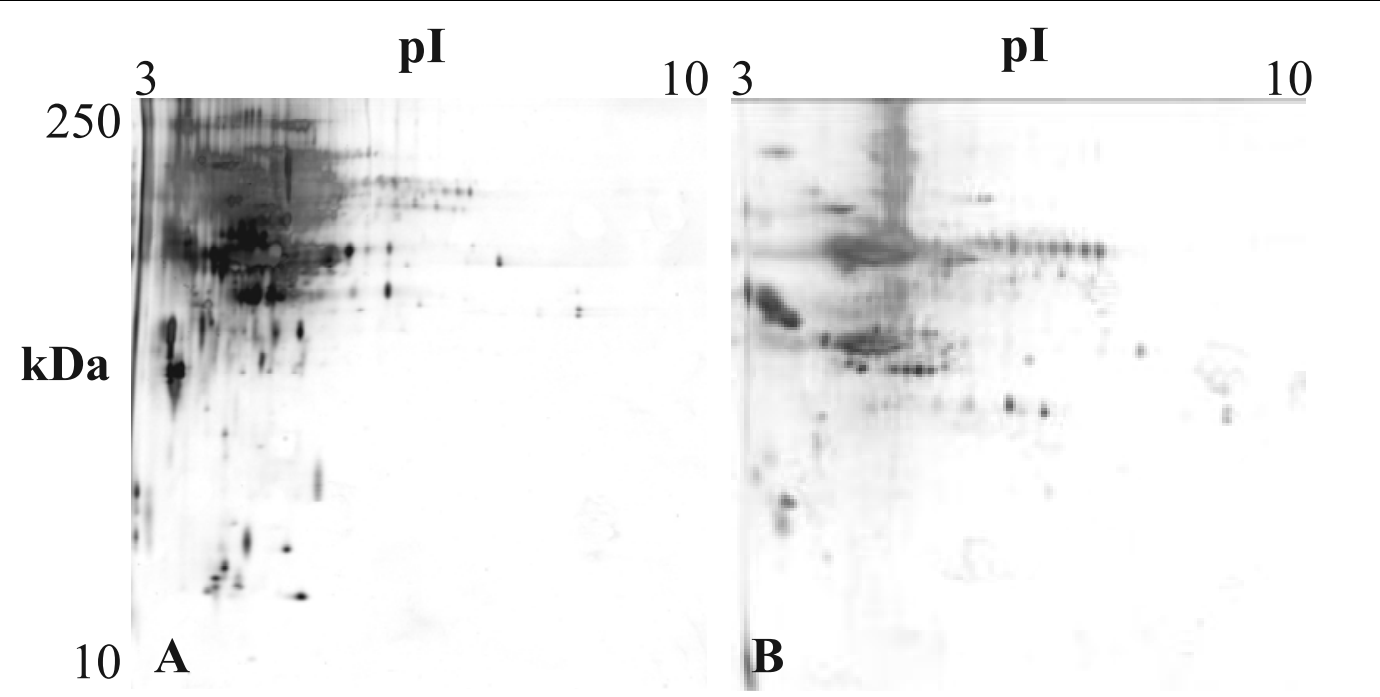

Fig. 1. 2D-gels from supernatant proteins of a 14 days-old fresh culture of $T$. versicolor. Proteins were separated before by $18 \mathrm{~cm}$ IPG strips for 49,700 Vhr. Approximately $100 \mu \mathrm{g}$ protein were loaded on the IPG strips. Gel (A) non-induced sample and gel (B) 2,5-xylidine-induced culture sample. Gels were stained by silver staining. 
Therefore experiments for optimization of protein amount were performed using supernatant sample of 2,5-xylidine induced cultures. Usage of $20 \mu \mathrm{g}$ protein resulted in only few spots on a 2D-gel, $40 \mu \mathrm{g}$ and $70 \mu \mathrm{g}$ showed an increase in numbers of protein spots and $100 \mu \mathrm{g}$ of protein resulted in maximum number of protein spots with silver staining (Fig. 2D). However, increase in protein amount more than $100 \mu \mathrm{g}$ lead to overstaining of gels when applying silver staining (observations not shown).

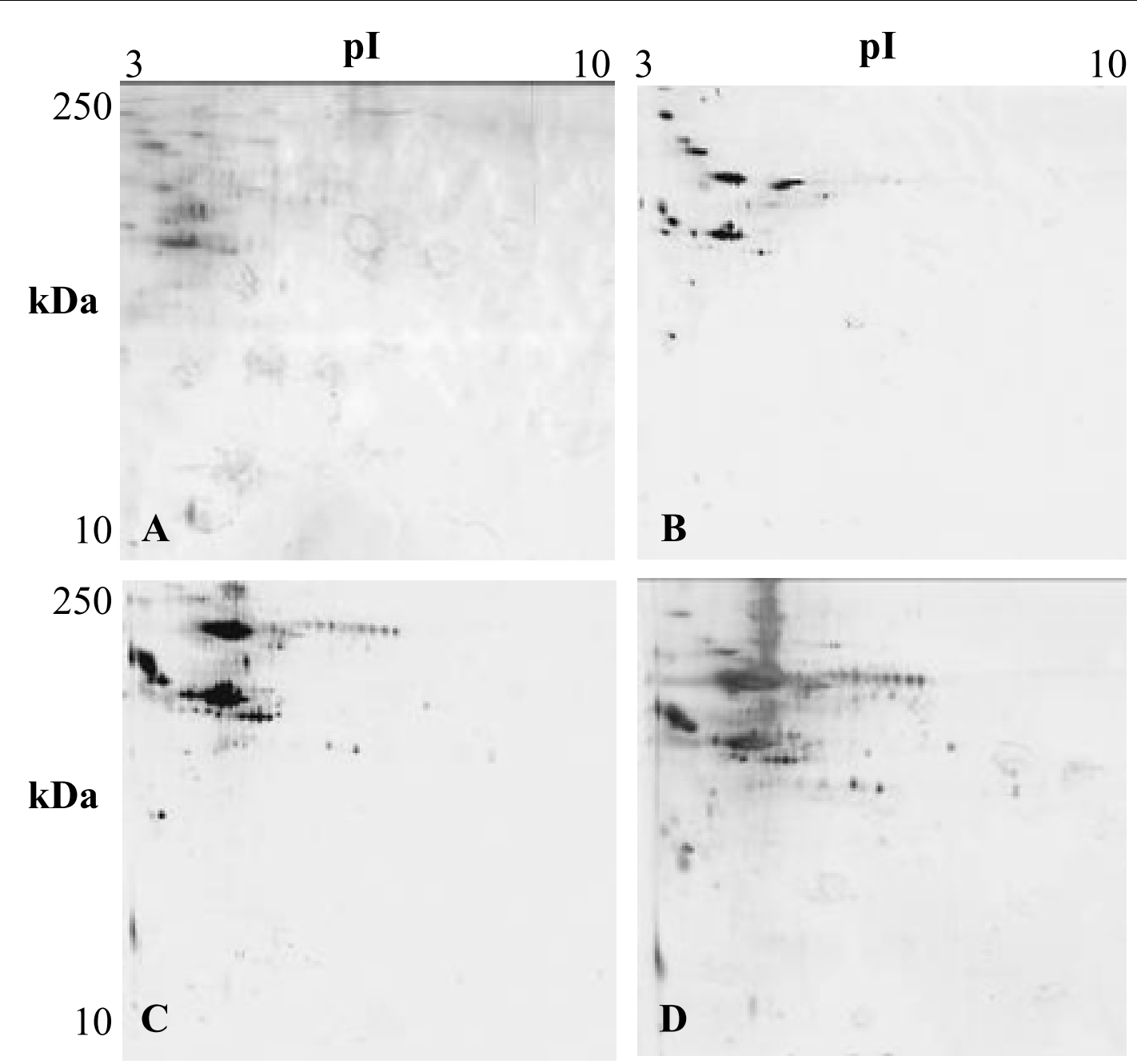

Fig. 2. 2D-gels from different amount of supernatant proteins from a 14 days-old 2,5-xylidine-induced fresh culture of T. versicolor. Proteins were separated by $18 \mathrm{~cm}$ IPG strips for $49,700 \mathrm{Vhr}$. Approximately $20 \mu \mathrm{g}$ of protein (A), $40 \mu \mathrm{g}$ of protein (B), $70 \mu \mathrm{g}$ of protein $(\mathbf{C})$ and $100 \mu \mathrm{g}$ of proteins (D) were loaded on the IPG strip. All gels were stained by silver staining. Note that in Note that in Fig. $\mathrm{A}, \mathrm{B}$ and $\mathrm{C}$ a new fresh culture supernatant was used while in Fig. D the same culture was used as in Fig. $1 \mathrm{~B}$. 
Different staining methods (Silver staining, modified silver staining and Coomassie staining) were tested and used to stain 2D-gels. Commonly used silver staining which is a very sensitive staining method and can stain proteins in a range of $0.1 \mathrm{ng}$ resulted in a maximum number of visible spots. Improved silver staining (Mortz et al. 2001) (claimed for mass spectrometry compatibility) resulted in relatively faint spots (Fig. 3). Because of the low intensity, all the spots could not be visualized on the gel making it difficult to pick the spots from the 2D-gels.

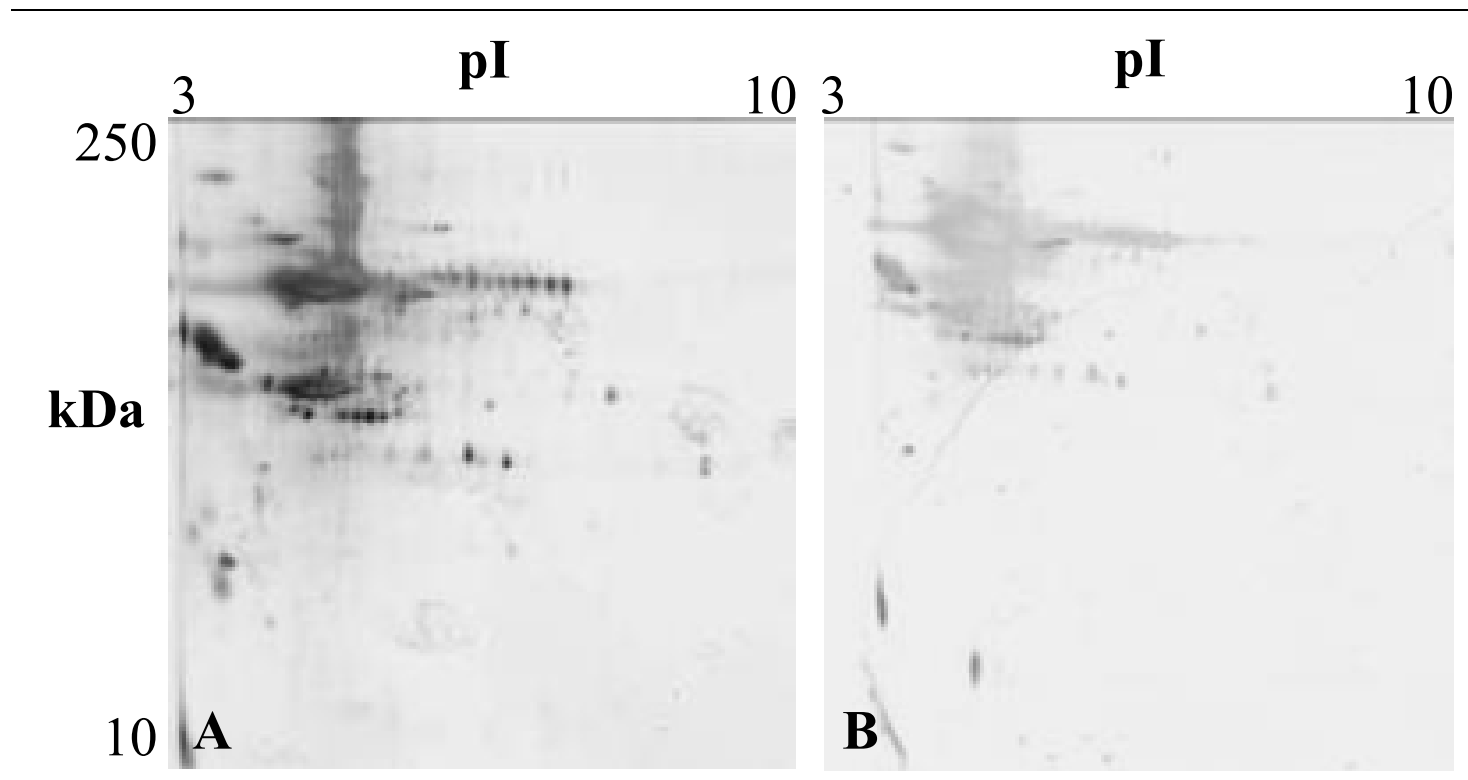

Fig. 3. 2D-gels from supernatant proteins of a 14 days-old 2,5-xylidine-induced fresh culture from $T$. versicolor, separated before by $18 \mathrm{~cm}$ IPG strips for 49,700 Vhr. Approximately $100 \mu \mathrm{g}$ protein was loaded on the IPG strip. Gel (A) was stained by Blum protocol and gel (B) was stained by improved silver staining. Note that the culture supernatant was the same as that used in Fig. 1 B (2, 5-xylidine induced culture).

Coomassie staining which is known to be compatible with mass spectrometry analysis (Candiano et al. 2004) was performed for $100 \mu \mathrm{g}, 200 \mu \mathrm{g}$ and $300 \mu \mathrm{g}$ of protein amount. Staining with $100 \mu \mathrm{g}$ protein showed 95 spots, $200 \mu \mathrm{g}$ in 121 spots and $300 \mu \mathrm{g}$ in 90 spots (Fig. 4). $100 \mu \mathrm{g}$ of protein amount gave relatively fewer protein spots while 300 $\mu \mathrm{g}$ lead to over-saturation of protein spots and poor separation of proteins in IEF. However, $200 \mu \mathrm{g}$ protein loading lead to an optimum separation of proteins in IEF and to a maximum number of protein spots. The sensitivity of Coomassie staining is in a range of $1.0 \mathrm{ng}$ (Candiano et al. 2004). Therefore, the same number of protein spots could not 
be detected for the same amount of $100 \mu \mathrm{g}$ protein when compared to silver staining. Therefore, Coomassie staining was used for protein identification purpose and the low sensitivity was taken care of by using more protein sample (up to $200 \mu \mathrm{g}$ ) to detect maximum numbers of visible spots in Coomassie stained gels (Fig. 4).

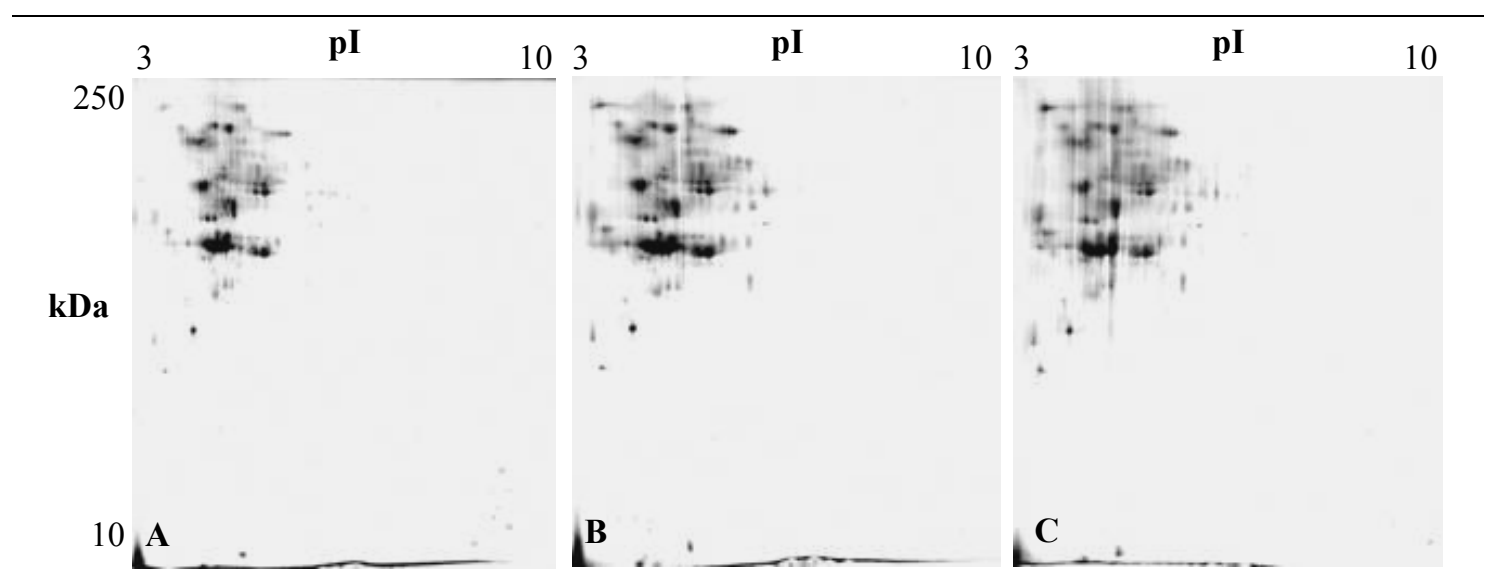

Fig. 4. 2D-gels from supernatant proteins of a 14 day-old non-induced fresh culture of T. versicolor. Proteins were separated before by $18 \mathrm{~cm}$ IPG strips for 62,000 Vhr. Gels (A), (B) and (C), containing 100,200 and $300 \mu \mathrm{g}$ of protein, respectively, were stained with Coomassie staining. Note that the culture supernatant was from a different culture than that shown in Figs. 1 to 3.

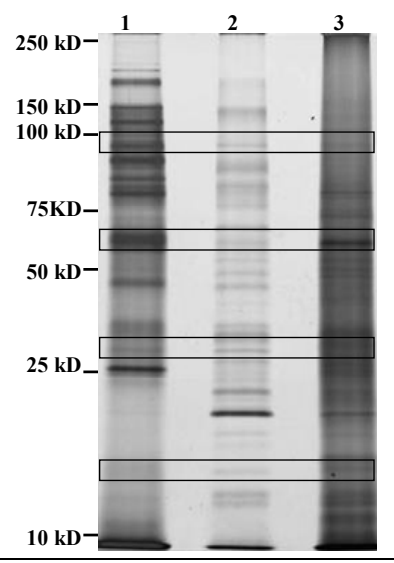

Fig. 5. 1D-electrophoresis of from the supernatant proteins of a 14 days-old culture (lane-1), hyphal sheath proteins (lane-2) and non-covalently bound cell-wall proteins from non-induced cultures of $T$. versicolor. Boxes show presence for similar size of protein bands present in all the three extra-cellular fractions. The sizes of molecular weight markers are indicated. The gel was stained by the silver staining method. Approximately $10 \mu \mathrm{g}$ protein was loaded in each lane. Note that a fresh culture was used for Fig. 5 that was different from the cultures analyzed in Fig. 1-4.

Having tested and standardized the conditions for 2D-analysis of proteins from the $T$. versicolor, the extra-cellular proteins i.e. supernatant proteins, hyphal sheath associated proteins and cell wall associated proteins (non-covalently and covalently bound) from $T$. versicolor were isolated and analyzed by 1D- and 2D-electrophoresis. After 1Delectrophoresis, only a few bands that were similar in all the three fractions of extra- 
cellular proteins (supernatant, hyphal sheath and non-covalently bound cell wall associated proteins) were found and are indicated by arrows in Fig. (5).

Similar results were observed after 2D-electrophoresis of the extra-cellular fractions. Only few protein spots from the supernatant matched to the proteins from hyphal sheath or non-covalently bound cell wall proteins (Fig. 6). Each fraction represents a unique part of the proteome of secreted proteins. Only few additional proteins could be released by treatment of the remaining cell walls with 1,3-glucanase (Fig. 6D).

Most of the proteins (shown by circles in Fig. 6) in the supernatant proteome of $T$. versicolor were in the acidic pI range from 3.0 to 6.0 with a molecular weight range of $50 \mathrm{kDa}$ to $150 \mathrm{kDa}$. The hyphal sheath proteins showed a distinct pattern of protein separation after 2D-electrophoresis which can be divided into two groups, a first group with $\mathrm{pI}$ values ranging between 3.0 to 5.0 and a molecular weight range of $75 \mathrm{kDa}$ to 150 $\mathrm{kDa}$, and a second group with a pI range of 4.0 to 6.5 and a molecular weight of $15 \mathrm{kDa}$ to $75 \mathrm{kDa}$. The non-covalently bound cell wall associated proteins showed nearly neutral $\mathrm{pI}$ values of 5.5 to 6.5 with a molecular weight range of $25 \mathrm{kDa}$ to $100 \mathrm{kDa}$. While the covalently bound proteins separated into two groups, one with a acidic $\mathrm{pI}$ in the range of $3.5-4.0$ and a molecular weight range of $10 \mathrm{kDa}$ to $37 \mathrm{kDa}$, and one with nearly neutral pI values of 7.5-8.0 having molecular weights between $75 \mathrm{kDa}$ to $100 \mathrm{kDa}$. The proteome of the non-covalently bound cell wall proteins was unique as compared to the other two parts of extracellular proteome.

The extra-cellular proteins from the supernatant of T. versicolor were analyzed by ESILC-MS analysis. Nearly all of the visible spots from the Coomassie stained 2D-gel (200 $\mu \mathrm{g}$ of protein concentration) were picked up individually (97 spots in total), digested by trypsin and analyzed by ESI-LC-MS (Fig. 7). Proteins like laccases, lignin peroxidase isozyme precursor, manganese peroxidase, manganese-repressed peroxidase (Table 1) were successfully identified, while the majority of the spots (90 in total) remained undetected by ESI-LC-MS analysis. The T. versicolor genome is not sequenced up to now and identification of proteins could only be performed by searching the available protein databases such as NCBI (http://www.ncbi.nlm.nih.gov/), MSDB 
(http://www.matrixscience.com/), TrEMBL (http://www.expasy.org/sprot/). Only 132 entries for T. versicolor were present in the NCBI database (15 September 2005).

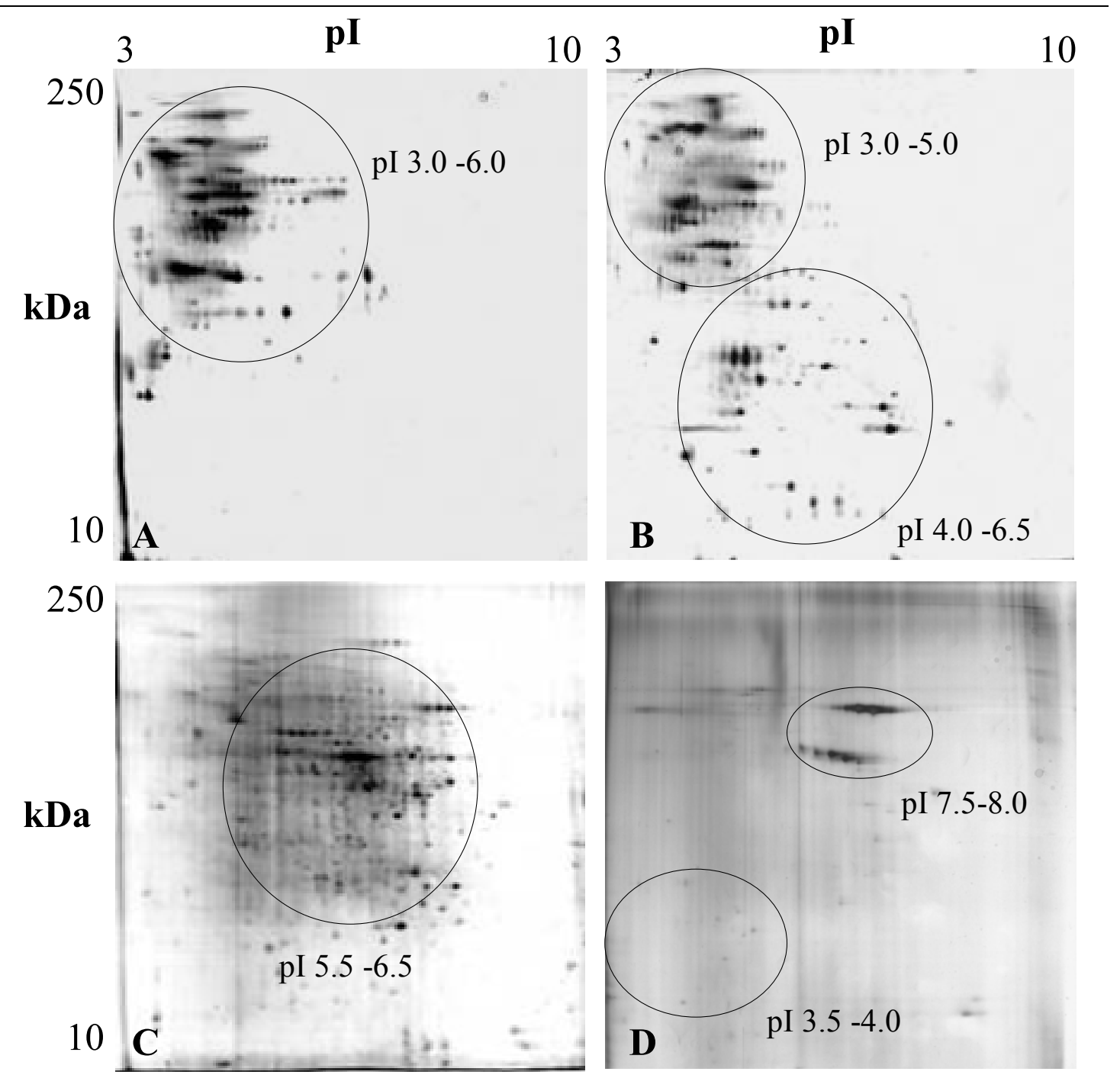

Fig. 6. 2D-gels from extracellular proteins of a 14 days-old non-induced fresh culture from T. versicolor, supernatant proteins (A), hyphal sheath associated proteins (B), non-covalently bound cell wall associated proteins (C) and covalently bound cell wall proteins (D). Approximately $100 \mathrm{mg}$ protein were loaded and separated on IPG strips for subsequent separation on 2D-gels. Circles indicate the pI range for the majority of proteins of the respective samples separated in 2D-electrophoresis. Note that the culture supernatant used in Fig. $6 \mathrm{~A}$ is the same as that used in Fig. 5, Lane-1, the hyphal sheat proteins used in Fig. $6 \mathrm{~B}$ are from the same sample than that used in Fig. 5, Lane-2, and the non-covalently bound cell-wall proteins used in Fig. $6 \mathrm{C}$ are from the same sample than that used in Fig. 5, Lane-3. Fig. $6 \mathrm{D}$ is from the sample as Fig. $6 \mathrm{C}$ obtained from further treatment of cell walls after the removal of noncovalently bound proteins. 
However, several entries are redundant and point to only a few of enzymes: laccase I, II, III, IV, unspecified laccases, lignin peroxidase isozymes, manganese peroxidase, manganese-repressed peroxidase, cellobiose dehydrogenase, ß-glucanase, chitin synthases, glyceraldehyde-3-phosphate dehydrogenase, oxalate decarboxylase and copper chaperone TahA. The last four proteins are not supposed to be freely secreted to the culture liquid. From the remaining six groups of proteins, four (laccase, manganese peroxidase, lignin peroxidase, and manganese-repressed peroxidase) were identified by ESI-LC-MS in the supernatant. Cellobiose dehydrogenase and ß-glucanase are potentially extracellular enzymes (Leonowicz et al. 1999; Henriksson et al. 2000). However, such enzymes were not found in this study and it is possible that they were not secreted under the culture conditions used in the experiments (glucose media). That 90 spots from of 97 spots analyzed in total in this study remained un-defined is likely because not many of proteins are yet known from T. versicolor.

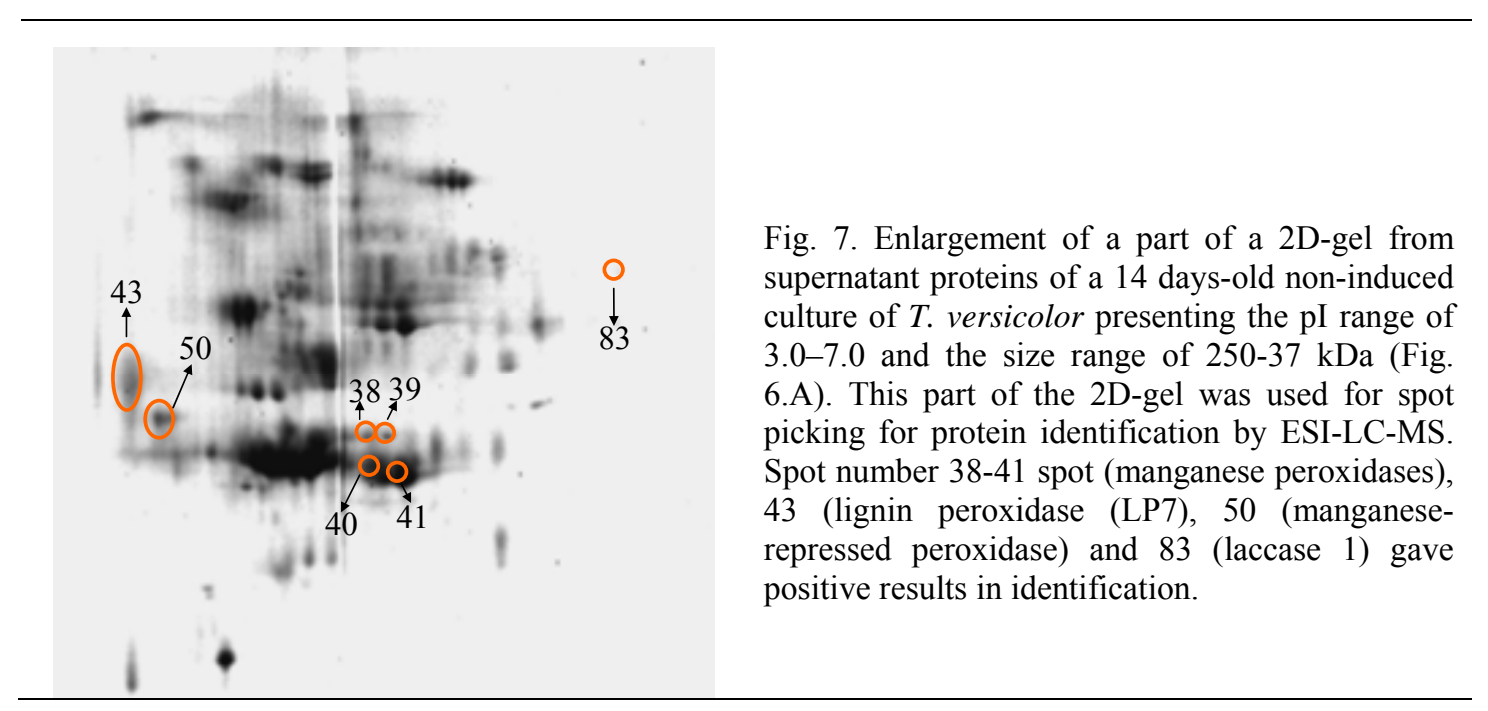

Table 1. Identification of supernatant proteins from a 14 days-old non-induced culture of $T$. versicolor (picked from the 2D-gel shown in Fig. 6.A)

\begin{tabular}{|c|c|c|c|c|c|c|c|}
\hline No & $\begin{array}{l}\text { Peptides identified by ESI- } \\
\text { LC-MS }\end{array}$ & $\begin{array}{l}\text { Peptide } \\
\text { score }\end{array}$ & Protein identification & $\begin{array}{l}\text { Total } \\
\text { score }\end{array}$ & $\begin{array}{l}\text { Cove } \\
\text { rage }\end{array}$ & pI & $\begin{array}{l}\text { MW } \\
\text { kDa }\end{array}$ \\
\hline 38 & $\begin{array}{l}\text { K.MTVLGQNTR.E } \\
\text { Oxidation (M) } \\
\text { R.LTFHDAIGISPAIAR.T }\end{array}$ & $\begin{array}{l}30 \\
25\end{array}$ & $\begin{array}{ll}\text { Manganese } & \text { peroxidase } \\
\text { isozyme } T . & \text { Versicolor : } \\
\text { AAT90351 } & \end{array}$ & 87 & 11 & 4.9 & 38 \\
\hline
\end{tabular}




\begin{tabular}{|c|c|c|c|c|c|c|c|c|}
\hline 39 & $\begin{array}{l}\text { R.LQSDAELAR.D } \\
\text { K.MTVLGQNTR.E } \\
\text { R.LTFHDAIGISPAIAR.T }\end{array}$ & $\begin{array}{l}47 \\
40 \\
35\end{array}$ & $\begin{array}{l}\text { Manganese } \\
\text { isozyme } T \text {. } \\
\text { AAT90351 }\end{array}$ & $\begin{array}{r}\text { peroxidase } \\
\text { Versicolor : }\end{array}$ & 148 & 16 & 4.9 & 38 \\
\hline 40 & $\begin{array}{l}\text { R.LTFHDAIGISPAIAR.T } \\
\text { K.MTVLGQNTR.E } \\
\text { R.LQSDAELAR.D }\end{array}$ & $\begin{array}{l}73 \\
38 \\
24\end{array}$ & $\begin{array}{l}\text { Manganese } \\
\text { isozyme } T \text {. } \\
\text { AAT90351 }\end{array}$ & $\begin{array}{l}\text { peroxidase } \\
\text { Versicolor : }\end{array}$ & 163 & 14 & 4.9 & 38 \\
\hline 41 & $\begin{array}{l}\text { R.LTFHDAIGISPAIAR.T } \\
\text { R.LQSDAELAR.D }\end{array}$ & $\begin{array}{l}49 \\
48\end{array}$ & $\begin{array}{l}\text { Manganese } \\
\text { isozyme } T \text {. } \\
\text { AAT90351 }\end{array}$ & $\begin{array}{l}\text { peroxidase } \\
\text { Versicolor : }\end{array}$ & 176 & 16 & 4.9 & 38 \\
\hline 83 & $\begin{array}{l}\text { R.GPFVVYDPK.D } \\
\text { R.FPLGADATLINGLGR.S }\end{array}$ & $\begin{array}{l}22 \\
19\end{array}$ & Laccase $1 T$. & versicolor & 47 & 7 & 5.9 & 56 \\
\hline 43 & $\begin{array}{l}\text { R.LQTDHLLAR.D } \\
\text { K.NTATNAACCSLFAVR.D }\end{array}$ & $\begin{array}{l}59 \\
34\end{array}$ & $\begin{array}{l}\text { Lignin perox } \\
\text { versicolor : } \mathrm{C}\end{array}$ & $\begin{array}{l}\text { kidase, LP7 } T \text {. } \\
\text { AA83147 }\end{array}$ & 92 & 6 & 4.7 & 39 \\
\hline 50 & R.LQSDFLIGR.D & 40 & $\begin{array}{l}\text { Manganese-r } \\
\text { peroxidase } T \\
\text { AAB63460 }\end{array}$ & epressed & 72 & 4 & 4.3 & 38 \\
\hline
\end{tabular}

\subsubsection{Conclusion}

This work investigated and established basic proteomics tools for $T$. versicolor. Supernatant, mycelia associated, non-covalently and covalently bound proteins were separated by $2 \mathrm{D}$-electrophoresis. However, the identification of proteins was strongly limited by lacking a complete database for $T$. versicolor genes, respectively their proteins.

\subsection{References}

Bertrand T., Jolivalt C., Briozzo P., Caminade E., Joly N., Madzak C., and Mougin C. (2002). Crystal structure of a four-copper laccase complexed with an arylamine: Insights into substrate recognition and correlation with kinetics. Biochemistry 41:7325-7333.

Blum H., Beier H., and Gross H.J. (1987). Improved silver staining of plant proteins, RNA and DNA in polyacrylamide gels. Electrophoresis 8:93-99.

Candiano G., Bruschi M., Musante L., Santucci L., Ghiggeri G.M., Carnemolla B., Orecchia P., Zardi L., and Righetti P.G. (2004). Blue silver: A very sensitive colloidal Coomassie G-250 staining for proteome analysis. Electrophoresis 25:1327-1333.

Damerval C., Devienne D., Zivy M., and Thiellement H. (1986). Technical Improvements in two dimensional electrophoresis increase the level of genetic variation detected in wheat seedling proteins. Electrophoresis 7:52-54.

Daniel G. (1994). Use of electron microscopy for aiding our understanding of wood biodegradation. FEMS Microbiology Reviews 13:199-233. 
Havlis J., Thomas H., Sebela M., and Shevchenko A. (2003). Fast-response proteomics by accelerated in-gel digestion of proteins. Analytical Chemistry 75:1300-1306.

Henriksson G., Johansson G., and Pettersson G. (2000). A critical review of cellobiose dehydrogenases. Journal of Biotechnology 78(2):93-113.

Hofrichter M. (2002). Review: lignin conversion by manganese peroxidase (MnP). Enzyme and Microbial Technology 30:454-466.

Jones C.L., and Lonergan G.T. (1999). Histochemical detection of laccase in Pycnoporus cinnabarinus using microwave-enhanced colloidal gold microcrystallization. Biotechnology Techniques 13:871-875.

Laemmli U.K. (1970). Cleavage of structural proteins during assembly of head of bacteriophage T4. Nature 227:680-685.

Latgé J.P., and Calderone R. (2006). The fungal cell wall. In: The mycota, growth, differentiation and sexuality Vol. I, $2^{\text {nd }}$ edition (Kües and Fischer eds.), Springer-Verlag, Heidelberg, in press.

Leonowicz A., Matuszewska A., Luterek J., Ziegenhagen D., Wojtas-Wasilewska M., Cho N.S., Hofrichter M., and Rogalski J. (1999). Biodegradation of lignin by white rot fungi 50. Fungal Genetics and Biology 27:175-185.

Leonowicz A., Cho N.S., Luterek J., Wilkolazka A., Wojtas-Wasilewska M., Matuszewska A., Hofrichter M., Wesenberg D., and Rogalski J. (2001). Fungal laccase: properties and activity on lignin. Journal of Basic Microbiology 41:185-227.

Masuoka J., Guthrie L.N., and Hazen K.C. (2002). Complications in cell surface labelling by biotinylation of Candida albicans due to avidin conjugate binding to cell wall proteins. Microbiology-Sgm 148:1073-1079.

Matsumura E., Yamamoto E., Numata A., Kawano T., Shin T., and Murao S. (1986). Structures of the laccase catalyzed oxidation products of hydroxy benzoic acids in the presence of ABTS (2,2'-Azino-Di-(3-Ethylbenzothiazoline-6-Sulfonic Acid)). Agricultural and Biological Chemistry 50:1355-1357.

Mortz E., Krogh T.N., Vorum H., and Görg A. (2001). Improved silver staining protocols for high sensitivity protein identification using matrix-assisted laser desorption/ionization-time of flight analysis. Proteomics 1:1359-1363.

Peterson G.L. (1977). Simplification of protein assay method of lowry et al. which is more generally applicable. Analytical Biochemistry 83:346-356.

Piontek K., Antorini M., and Choinowski T. (2002). Crystal structure of a laccase from the fungus Trametes versicolor at 1.90-angstrom resolution containing a full complement of coppers. Journal of Biological Chemistry 277:37663-37669. 
Rast D.M., Baumgartner D., Mayer C., and Hollenstein G.O. (2003). Cell wall-associated enzymes in fungi. Phytochemistry 64:339-366.

Ruel K., and Joseleau J.P. (1991). Involvement of an extracellular glucan sheath during degradation of populus wood by Phanerochaete chrysosporium. Applied and Environmental Microbiology 57:374-384.

Sietsma J.H., and Wessels J.G.H. (2006). Apical wall biogenesis. In: The Mycota, Growth, Differentiation and Sexuality $\mathbf{2}^{\text {nd }}$ Edition (Kües U., Fischer R. eds.), Springer-Verlag, Berlin Heidelberg, pp. 261-290.

Srebotnik E., and Messner K. (1998). Determination of the accessibility of lignocellulosic substrates to enzymatic degradation by immunoelectron microscopy. In: Institute of Physics Conference Series No. 93/3 Dickinson H.G., Goodhew P.J. (eds) EUREM 88. Bristol, Philadelphia:, pp 107108

Tuor U., Winterhalter K., and Fiechter A. (1995). Enzymes of white rot fungi involved in lignin degradation and ecological determinants for wood decay. Journal of Biotechnology 41:1-17.

Walser P.J., Velagapudi R., Aebi M., and Kües U. (2003). Extracellular matrix proteins in mushroom development. Rec. Res. Devel. Microbiol 7: 381-415.

Walser P.J., Haebel P.W., Kunzler M., Sargent D., Kues U., Aebi M., and Ban N. (2004). Structure and functional analysis of the fungal galectin CGL2. Structure 12:689-702.

Walser P.J., Kues U., Aebi M., and Kunzler M. (2005). Ligand interactions of the Coprinopsis cinerea galectins. Fungal Genetics and Biology 42:293-305.

Wösten H.A.B. (2001). Hydrophobins: Multipurpose proteins. Annual Review of Microbiology 55:625-646.

Xiao Y.Z., Tu X.M., Wang J., Zhang M., Cheng Q., Zeng W.Y., and Shi Y.Y. (2003). Purification, molecular characterization and reactivity with aromatic compounds of a laccase from basidiomycete Trametes sp strain AH28-2. Applied Microbiology and Biotechnology 60:700-707. 

General discussion and conclusion 



\section{General discussion and conclusion}

Biodegradation of wood that consists of cellulose $(40-50 \% \mathrm{dw})$, hemicellulose $(27-31 \%$ $\mathrm{dw})$, and lignin $(20-30 \% \mathrm{dw})$ is a natural process occurring continuously in the ecosystems (Morrell and Gartner 1998, Eriksson et al. 1990a). Wood biomass is mainly degraded by filamentous basidiomycetes but also by some ascomycetes that have specialized in using this substrate for their saprophytic or parasitic life styles. Wood decaying fungi are commonly divided into three groups: white rot fungi degrading extensive amounts of lignin present in the plant cell walls causing whitening of the substrate, brown rot fungi characterized by extensive degradation of cellulose and hemicellulose with limited ability to degrade lignin, and soft rot fungi (mostly ascomycetes and deuteromycetes) attacking wood with a high moisture content and causing cavities within the plant cell wall.

The biodegradation of insoluble polymeric fractions of lignocellulose by fungi is achieved by extracellular enzymes and oxidative radical processes initiated by the organisms. The conversion of the isolated polysaccharide compounds cellulose and hemicellulose by various hydrolases is considered a rather simple process. However, when these polysaccharides occur in complexes with lignin in a way typical for woody plants, they are resistant against simple hydrolytic breakdown (Leonowicz et al. 1999, 2001). Compared to the polysaccharides, lignin is structurally much more complex and made up primarily of phenylpropane units that must be cleaved via an oxidative mechanism (Gold et al. 1993). The highly polymeric aromatic structure of lignin makes wood highly resistant to degradation by microorganisms. Additionally, the presence of lignin makes the plant cells less permeant to water (Eriksson et al. 1990b). Lignin is covalently associated with hemicellulose via ether bonds, ester bonds and ligninglycosidic bonds (Tuor et al. 1995).

Most of the white rot basidiomyceteous fungi can degrade wood very efficiently (Tuor et al. 1995, Grönqvist et al. 2003). These fungi essentially get access to the cellulose and hemicellulose embedded in the lignin matrix, thereby degrading the lignin in the wood. They possess several extracellular oxidases and peroxidases: mainly ligninases, Mn- 
dependent peroxidases and laccases (Leonowicz et al. 1999) that can simultaneously oxidize phenolic and non-phenolic groups of lignin. The lignin is converted into partially degraded polymers, humic acids, fulvic acids, low molecular weight organics, and $\mathrm{CO}_{2}$ (Leonowicz et al. 1999). Several years of research on the lignolytic process has identified the essential enzymes responsible for lignin degradation as oxidases, peroxidases, dehydrogenases and hydrogen peroxide generating enzymes. Peroxidases include lignin peroxidase (LiP), manganese-dependent-peroxidase (MnP), manganese independent peroxidase (MIP), LiP like peroxidases etc. The most commonly occurring oxidoreductases are laccases that play a significant role in lignin degradation by most of white rot fungi (Grönqvist et al. 2003).

Alongside the enzymes freely secreted to the liquid phase by fungal mycelia, a large number of proteins that show enzymatic activity are associated with the mycelial cell wall (Rast et al. 2003). They are supposed to play an important physiological role and to participate in the uptake and metabolism of nutrients from the surroundings. The cell wall proteins (CWP) are generally associated with cell wall polysaccharides and are either linked to $\beta$-1,3-glucan through a connecting $\beta$-1,6-glucan moiety via a GPI anchor or directly to $\beta-1,3$-glucan via an alkali sensitive linkage. Identified cell wall associated fungal exo-enzymes fall into the following biochemical subclasses: oxidoreductases, Oglycosyltransferases, hexosyltransferases, aminoacyltransferases, phosphoric monoester hydrolases (Rast et al. 2003).

Trametes versicolor is one of the well studied white rot fungi among the basidiomycetes. It secretes a number of enzymes that are involved in the degradation of wood lignocellulose including: lignin peroxidase (LiP), manganese peroxidase (MnP) (Johansson and Nyman), laccase (Johannes and Majcherczyk 2000), carboxymethyl cellulase, avicelase (Tanaka et al. 1999) and cellobiose dehydrogenase (Dumonceaux et al. 1998).

All the studies to detect cell wall associated enzymes conducted in the past used an indirect approach to demonstrate the association of the enzymes with the cell wall. Laccase (phenoloxidase) was shown to be present in high concentration at the apical hyphal region in a wood rot basidiomycete, Pycnoporus cinnabarinus by co-precipitation 
of gold particles with a phenolic laccase substrate (Jones et al. 1999). Similarly, immunogold labelling in culture and in degraded wood samples showed lignin peroxidase and manganese peroxidase (MnP) were detected in degraded wood and on the surface of the fungal hypha (Ruel et al. 1991; Srebotnik et al. 1998). Daniel (1994) has been successful in localization of several redox- and hydrolytic enzymes in the cell wall of a couple of basidiomycetes including T. versicolor by immuno-gold labelling (Daniel 1994). Additionally, several other oxidative and hydrolytic enzymes such as aryl alcohol oxidase, pyranose oxidase and cellulase have been localized by immuno-gold labelling within the cell wall or the extracellular polysaccharide sheath of Volvariella volvacea (Cai et al. 1999).

However, due to the absence of effective methods for preparation of cell wall samples suitable for such studies, direct proteomic approaches to identify cell wall linked enzymes in the higher basidiomyceteous fungi had not been performed so far. From the work by Taubert et al. (2000) it is known that the methods generally used for the disruption of cell walls in ascomycetes can not be directly applied to the rigid cell walls of higher basidiomycetes. Several mechanical disruption methods have been tried but each resulted in dissatisfactory results. Usage of a percussion grinder with glass beads resulted only in partially broken mycelium from Ganoderma applanatum and Pycnoporus cinnabarinus (Taubert et al. 2000). A homogenizer with glass beads was found to be effective for breaking the cells of Agaricus bisporus (Sassoon et al. 2001). However the resultant cell wall samples were not found suitable for proteomic studies. In my studies, I tested several different procedures to break the cells from a wood rotting basidiomyceteous fungus $T$. versicolor, with the aim to obtain high quality cell wall fractions suitable for further proteomic analysis. The optimal method should preserve all their cell wall components, especially the associated proteins in their native form. Most of the procedures mentioned in the literature lead to excessive amount of heat generation in the sample. Therefore, it was important to control the temperature during the grinding procedure so that the proteins associated with the cells walls do not get denatured during the course of sample preparation. 
The commonly used methods of manual grinding by mortar and pestle and the use of Ultra-Turrax was largely ineffective. Each of these methods resulted in very mild disruption of the mycelia and flocculation of the partially disrupted mycelial fragments. This could possibly be because the cell walls in the basidiomycetes are excessively tough for these relatively milder forms of disruption. The use of bead beater produced too much heat in the samples, which is not advisable if the proteins have to be studied in their native form. Grinding the mycelia with tungsten carbide balls in plastic micro tubes resulted in an only partially broken mycelia. This is possibly because the rubbing of tungsten carbide balls against the plastic surface does not provide enough shearing force to disrupt the mycelia completely and the scanning electron microscopic pictures showed presence of long undisrupted hyphae in the sample. The most effective method found during my studies was the use of a $20 \mathrm{~mm}$ diameter stainless steel ball for grinding the mycelia in a $25 \mathrm{ml}$ stainless steel container. Scanning electron microscopy analysis clearly showed the absence of any large hyphal strands confirming the fine disruption of the mycelia. This technique works well primarily due to better contact between the ball and the container or due to the high disruptive force generated by rubbing of stainless steel balls and against the stainless steel jar surface. The energy-dispersive X-ray microanalysis (EDAX) analysis of these cell wall samples showed trace amounts iron and other metals thereby ruling out the possibility of contamination due to abrasion from the apparatus. Additionally, the sample was immersed into liquid nitrogen at regular intervals to ensure low temperature during course of preparation.

When crude cell wall fractions are prepared from the mycelium, there are high chances of contaminating the material with intracellular components. For this reason, I purified the cell wall fraction further by sequential washes with the breaking buffer and sorbitol gradient. These treatments led to a high quality pure cell wall fractions, which were positively tested for the presence of native enzymatic activities. Thus, I was able to develop a highly efficient method for obtaining high quality cell wall samples from T. versicolor and this method was found equally effective for another basidiomycete, i.e. P. ostreatus. The developed method is supposed to be also applicable to other fungi. 
My further aim was to obtain the non-covalently and covalently bound proteins from the cell wall fractions of $T$. versicolor and analyze these proteins with classical proteomic tools. I started with the non-covalently bound proteins which were removed from the cell walls rather easily by treatment with detergents. This showed that the purified cell wall samples have the associated proteins and enzymes in their intact form and the proteins could be separated well on 1D- and 2D-gels.

In addition, wood degrading basidiomycetes secrete several extracellular proteins that may be located in the cell wall or associated with the substrate. In white-rot fungi, extracellular enzymes like laccase, lignin peroxidase, manganese peroxidase (MnP) are known to be involved in breakdown of growth substrate (Tuor et al. 1995; Leonowicz et al. 1999; 2001; Hofrichter 2002). In the past, studies have focussed largely on the individual extracellular proteins from $T$. versicolor. Therefore, it was very interesting for me to try to study the extracellular proteins of T. versicolor at the proteome level. The extracellular proteins comprise of the supernatant proteins, the hyphal sheath associated proteins and cell wall associated proteins (non-covalently and covalently bound). I aimed at studying both the supernatant proteins obtained from the culture medium and the cell wall associated proteins by solubilizing them from the cell wall fractions using detergent SDS and reducing agent $\beta$-mercaptoethanol followed by 1,3-glucanase digestion of remaining CWF's.

I found that, the samples of the supernatant proteins and cell wall associated proteins contained a high amount of polysaccharides. The cell wall has a high abundance of polysaccharides that form the major structural component. The fungi secrete also some polysaccharides into the supernatant of liquid culture. The presence of polysaccharides in the samples gives an intense background and interferes with the detection of proteins bands on 1D- and 2D-gels. Additionally, there was a need to standardize the procedure for the separation and detection of the proteins on the gels. $200 \mu \mathrm{g}$ of protein loaded on the 1D- and 2D-gels gave the best resolution and were optimally detected by Coomassie staining which is more compatible for mass spectrometry than the highly sensitive silver staining. 
The protein fractions obtained from the supernatant proteins, hyphal sheath associated proteins, and cell wall associated proteins (non-covalently and covalently bound) from cultures of T. versicolor were separated on 1D- and 2D-gels. Each of the fractions showed the presence of some unique proteins in addition to the common proteins. This difference in the protein profile is easy to understand. Some proteins are constitutively secreted into the surrounding by the fungi for functions like degradation of the substrates, while some proteins and enzymes have a specific localization either to the hyphal sheath or to the cell wall depending on the function of the proteins or enzymes. Further, there are many common proteins that form, for example, the structural components of the hyphal sheath and the cell wall and are therefore commonly detected in these fractions. Additionally, the secreted proteins have to traverse through the cell wall and the hyphal sheath to get to the outside of the cells. That way such proteins can be also detected in all the three fractions on the way of their delivery outside of the cells.

I further found that each fraction presents a unique part of the proteome of the secreted proteins. The proteins from the supernatant proteome of $T$. versicolor lie in a relatively acidic pI range of 3.0 to 6.0 . The proteins in the hyphal sheath tend to fall into two pI ranges, first set of proteins has $\mathrm{pI}$ values ranging from 3.0 to 5.0 with a molecular weight range of $75 \mathrm{kDa}$ to $150 \mathrm{kDa}$ and second group has a $\mathrm{pI}$ range of 4.0 to 6.5 with a molecular weight of $15 \mathrm{kDa}$ to $75 \mathrm{kDa}$. The maximum number of bands in $1 \mathrm{D}$ and proteins spots in 2D gels were seen in the non-covalently bound cell wall fraction. Proteins from this fraction showed nearly neutral pI values of 5.5 to 7.5 with a molecular weight range of $25 \mathrm{kDa}$ to $100 \mathrm{kDa}$. The covalently bound proteins had two groups, one with an acidic $\mathrm{pI}$ range 3.5-4.0 and a molecular weight range of $10 \mathrm{kDa}$ to $37 \mathrm{kDa}$, and one with a nearly neutral $\mathrm{pI}$ values of 7.5-8.0 having molecular weights between $75 \mathrm{kDa}$ to $100 \mathrm{kDa}$.

The extra-cellular proteins from the supernatant of T. versicolor were analysed by ESILC-MS. However, the genome of T. versicolor is not yet sequenced and identification of proteins was performed by searching the available databases such as NCBI (http://www.ncbi.nlm.nih.gov/), MSDB (http://www.matrixscience.com/), TrEMBL (http://www.expasy.org/sprot/). Proteins like laccases, lignin peroxidase isozyme 
precursor, manganese peroxidase, manganese-repressed peroxidase were successfully identified in the supernatant from $T$. versicolor. However, most of the spots could not be identified due to the absence of a complete database.

It must be noted that most of the membrane associated protein and hyphal proteins are difficult to extract. Additionally, there is a high possibility that the cell wall harbours a large number of cell wall associated redox enzymes which have still not been isolated and identified. Also, the fungi can inhabit a wide range of habitats and have to obtain nutrition from varied sources. Therefore, they have to produce and secrete a lot of digestive enzymes to the surrounding. This raises the possibility that more degradative enzymes could be present in the supernatant and some have still not been identified. It would be very interesting to discover more of such enzymes from the supernatant and cell walls of the wood decaying fungi like T. versicolor. However, the least requirement for investigation and identification of extracellular proteins would be a completely sequenced genome of the organism.

Some enzymes show a high specificity towards their substrate while others can act on a broad range of substrates. Additionally, there are several molecules that can act as specific synthetic substrates for certain enzymes. These synthetic substrates can be conveniently used to detect the presence of the specific enzyme in samples of interest. Often, such substrates yield a product that can be visualized and quantified, for example by colored product development. This direct approach is often used for in-gel detection of enzymes, whereby the protein samples are separated on native gels and probed with different substrates to look for the presence of substrate specific enzymes in the sample in gel.

Laccase is a phenoloxidase belonging to the family of blue multi-copper oxidases and is involved in fungal lignin degradation. Phenoloxidases can accomplish the reduction of oxygen to water by the oxidation of aromatic substrates such as monophenols, ortho- and para-diphenols, polyphenols, methoxyphenols, ABTS [2,2'-azino-bis(3ethylbenzothiazoline-6-sulfonic acid)], ascorbic-, coumaric-, sinapic-, gallic-, ferullic-, coniferylic-, caffeic acid, aromatic diamines and lignin (Smith et al. 1997). There are several known substrates for phenoloxidases that lead to a coloured product and can be 
used for in-gel detection of these enzymes. These substrates include ABTS [2,2'-Azinobis(3-ethylbenzothiazoline-6-sulfonic acid)], $\alpha$-naphthol, TMA (N,N,N',N'-tetramethyl1,4-phenylenediammonium dichloride), MBTH (3-methyl-2-benzothiazolinon-hydrazonhydrochlorid monohydrat), DHPPA (3,4-dihydroxyhydrocinnamic acid), DAN (1,8diaminonaphthalene) etc. A number of studies report the use of these substrates for detection of phenoloxidases. Compounds such as guaiacol (Dong et al. 2005), pyrogallol, DMP (2,6-dimethoxyphenol), ABTS (Xiao et al. 2003) and DAN (1,8diaminonaphthalene) (Hoopes et al. 2001) that form chromogenic products upon enzymatic oxidation have been used for localization of enzymes in gel after separation.

MBTH (3-methyl-2-benzothiazolinon-hydrazon hydrochloride) traps o-quinone products of enzymatic oxidation of phenolic compounds such as DHPPA (3,4dihydroxyhydrocinnamic acid) and 4HA (4-hydroxyanisole) and forms a red color adduct (Dicko et al. 2002). However, there is no comprehensive study that compares the specificities and sensitivities of the substrates for in gel detection. I aimed at performing a rather extended and comprehensive study to compare the substrates and their combinations and identify the substrates that give best detection of phenoloxidases.

Phenoloxidases were detected among the supernatant proteins of two basidiomycetes Coprinopsis cinerea and T. versicolor. The supernatant proteins from copper and 2,5xylidine-induced cultures of $C$. cinerea and $T$. versicolor, respectively, were electrophoretically separated on 1D-native gels. The gel strips were then incubated with different substrates, coreactants and the combinations and the combination of substrates and coreactants. In-gel detection of PO's depends on how well the enzyme can react with different substrates and combinations of substrates with co-reactants. C. cinerea showed the highest number of PO sensitive bands, at the maximum six when stained with the combination of the two substrates TMA and $\alpha$-naphthol. The combination of TMA with the coreactant MBTH showed upto six different bands. Additionally, the combination of DAN with MBTH also gave five bands, but these were only poorly stained.

Although the staining with $\alpha$-naphthol + TMA showed a high sensitivity, one drawback was that the blue color products that were formed as a result of the enzyme-substrate reaction were highly unstable and that, in consequence, the staining quickly diffused 
away. In contrast, in MBTH + DHPPA staining a red colored MBTH-quinone adduct is formed (Dicko et al. 2002), which remains stable over the time even after few days of storage. Therefore, the substrates should be chosen depending on the aim of the study. For example, experiments that involve longer storage or extended handling of the gels should be stained with MBTH + DHPPA while the experiments that need very high sensitivity can use TMA $+\alpha$-naphthol for detection of phenoloxidases. Application of MBTH + DHPPA staining in isoelectric focusing enabled the detection of single isoforms of laccase and determinantion of their isoelectric points. This was not possible using TMA $+\alpha$-naphthol because of quick diffusion of the stained bands.

Although the in gel staining is a good method for detection of the phenoloxidases, it seems to render the enzymes incompatible for identification by LC-MS. I made several attempts to pick the in-gel stained spots for phenoloxidases and identify the enzymes by ESI-LC-MS. However, none of the identification attempts was satisfactory. This could possibly be either because the colored products somehow interfere with the sample preparation for ESI-LC-MS detection or that the reaction between the enzyme and substrate bring about some intrinsic change in the enzyme that makes its mass spectrometric identification very difficult.

Coomassie staining is known to be compatible for mass spectrometric analysis (Candiano et al. 2004). Two lanes from the same gel were stained one with substrates and other with Coomassie. While the native staining enabled the visualization of the phenoloxidase bands, excision of the corresponding band from Coomassie stained gel lane resulted in a successful identification of the phenol oxidases. Therefore, it is important to choose the method of staining depending on the objective of study.

Several studies in the past have detected and characterized supernatant laccases in different strains of T. versicolor (Morohoshi et al. 1987; Bertrand et al. 2002; Xiao et al. 2003; 2004). Three isoenzymes namely, laccase I, II, and III, have been described from supernatants of $T$. versicolor where laccase III was found to be the most abundantly secreted isoform and to be involved in lignin degradation (Morohoshi et al. 1987). Besides its presence in the supernatant, laccase is also found to be associated with the hypha. In the wood degrading basidiomycete $P$. cinnabarinus, co-precipitation of gold 
particles with a phenolic laccase substrate showed a high concentration of enzyme at the apical tip region of hyphae and a lower concentration on the exterior sub-apical hyphal sheath (Jones et al. 1999).

However, the laccases present in the cell wall of $T$. versicolor had not been characterized either in bound or free form. Also the cell wall laccases were never compared to the well known supernatant laccase from $T$. versicolor. It was interesting to know if the laccase associated with the cell wall has the same characteristics and functions as the supernatant laccase or whether they are two different forms of the same enzyme.

I was able to isolate and identify the supernatant laccase from 2,5-xylidine-induced cultures of $T$. versicolor as laccase III by ESI-LC-MS. The cell wall laccase was characterized in its cell wall bound form. The comparison of the characteristics of the two laccases revealed that the cell wall associated laccase was more temperature resistant and lost only about $25 \%$ of its activity compared to $50 \%$ activity loss of the supernatant laccase after six hours of incubation at $50^{\circ} \mathrm{C}$. Additionally, the cell wall bound form of laccase was more resistant to enzyme inhibitors compared to the supernatant laccase whose activity was inhibited at low concentrations of all the tested enzyme inhibitors. This gives an indication that the cell wall bound laccase is more stable than the supernatant laccase. This could possibly be due to interaction of laccase with some other proteins in the cell wall or laccase could be present in a thermally stable, inhibitor resistant conformation in the cell wall.

However, the substrate specificity of the two laccases was similar for one out of four tested substrates. This raises a possibility whether the two forms of laccase are actually the same enzyme with slightly modified properties in the cell wall bound and in the supernatant form.

Since the cell wall laccase in the cell wall bound form showed some distinct features compared to the supernatant, it was very interesting for us to know what happens to the cell wall associated laccase when it is released from the cell wall. Using immuno-gold labelling and scanning electron microscopy, it was found that the laccases are entrapped within the exo-polysaccharide shields of Ceriporiopsis subvermispora, Rigidoporus lignosus hyphae and also within the cell walls of Phlebia radiata (Nicole et al. 1992; 
Ruel et al. 2003). In the past, few attempts were made to release cell wall associated laccase, for example Zhu and co-workers reported that they could not release much of the cell wall associated laccase in C. neoformans, even after sequential treatments with salt, urea and SDS. However, glucanase treatment could successfully release the laccase from the cell wall (Zhu et al. 2001). Cell wall samples from A. bisporus sporocarps, showed phenoloxidase (tyrosinase) activity in several extracted fractions as well as in leftover pellet (Sassoon et al. 2001).

In this work, I tried to find an efficient method for releasing the cell wall-associated laccase from the cell wall from 2,5-xylidine induced cultures of $T$. versicolor. Some studies report the use of lytic enzyme, for example, Farina and coworkers used lytic enzymes of $T$. harzianum in a ratio of 1:1 (w/w) enzyme to fungal biomass (mycelium) for efficient protoplasting of the filamentous ascomycete Sclerotium rolfsii (Farina et al. 2004). It has also been previously emphasized that an increase in biomass in relation to the lytic mixture does not automatically yield higher numbers of protoplasts since this depends on the fact that the enzyme does not necessarily become limiting, and on the organism, and on the lytic conditions in general. Thus, the optimal biomass:enzyme ratio needs to be investigated for each individual fungal strain (Curragh et al. 1992). I used a similar approach to release laccase from the cell wall of $T$. versicolor. Several lytic enzymes, Trichoderma lysate, cellulase, chitinase, laminarinase together with reducing agents such as dithiothreitol (DTT) and tributylphosphine (TBP) were used in different combinations to get the maximum release. Reducing agents are thought to increase the porosity of the cell wall and thus to help in removal of non-covalently bound proteins associated with the cell wall (Molloy et al. 1995). However, DTT destroyed laccase activities and addition of TBP caused only sometimes an increase in laccase activity within the buffer. In a number but not all experiments in this thesis addition of lytic enzyme increased laccase activity in the buffer. There was therefore no final conclusion whether addition of enzymes is indeed beneficial compared to no addition of enzymes. However, sequential extraction with three lytic enzymes, first with the cellulase for 24 hrs followed by similar treatment with the chitinase and finally with Trichoderma lysate was effective in releasing the maximum amount of laccase. Additionally, I found that the 
procedure of laccase release was successful when the extraction was carried out in a horizontal shaker, while trials on a rotatory shaker was completely ineffective in releasing any laccase form the cell walls. This is possibly because the horizontal shaker provides more rigorous shaking and allows maximum access of the enzymes to the cell wall. The sample obtained from this procedure was separated on 1D-gel and stained ingel with TMA $+\alpha$-naphtol. It was found that there was one additional phenoloxidase band in these samples compared to the single laccase band in the supernatant. ESI-LCMS analysis of the two phenoloxidase bands revealed one band of lower molecular weight corresponding to laccase III. Therefore, this method of sequential release of enzymes from the cell wall proved to be highly efficient and can possibly be applied to extract other cell wall bound proteins from $T$. versicolor.

In conclusion, several proteomic methods were successfully optimized and implemented in the course of the work for the isolation and purification of degradative enzymes from higher basidiomycetous fungi. The lack of efficient techniques was a hurdle in studies concerning basidiomycetes. With this work many technical problems to perform proteomics studies for higher basidiomycetes have been solved and studied. High quality cell wall sample preparation, in-gel detection of several phenoloxidases, characterization of supernatant and cell wall associated laccase, release of cell wall associated laccase, extracellular (supernatant, hyphal sheath, noncovalently and covalently bound proteins) proteome analysis of T. versicolor were performed. Further, this work gave insight on the extracellularly secreted laccases and other phenoloxidases in the higher basidiomycetous fungi T. versicolor and C. cinerea.

\subsection{References}

Bertrand T., Jolivalt C., Caminade E., Joly N., Mougin C., and Briozzo P. (2002). Purification and preliminary crystallographic study of Trametes versicolor laccase in its native form. Acta Crystallographica Section D-Biological Crystallography 58:319-321.

Cai Y.J., Chapman S.J., Buswell J.A., and Chang S.T. (1999). Production and distribution of endoglucanase, cellobiohydrolase, and $\beta$-glucosidase components of the cellulolytic system of Volvariella volvacea, the edible straw mushroom. Applied and Environmental Microbiology 65:553-559. 
Candiano G., Bruschi M., Musante L., Santucci L., Ghiggeri G.M., Carnemolla B., Orecchia P., Zardi L., and Righetti P.G. (2004). Blue silver: A very sensitive colloidal Coomassie G-250 staining for proteome analysis. Electrophoresis 25:1327-1333.

Curragh H.J., Mooibroek H., Wessels J.G.H., Marchant R., and Mullan E. (1992). Protoplast formation and DNA-mediated transformation of Fusarium culmorum to hygromycin B resistance. Mycological Research 97:313-317.

Daniel G. (1994). Use of electron microscopy for aiding our understanding of wood biodegradation. FEMS Microbiology Reviews 13:199-233.

Dicko M.H., Hilhorst R., Gruppen H., Laane C., van Berkel W.J.H., and Voragen A.G.J. (2002). Zymography of monophenolase and o-diphenolase activities of polyphenol oxidase. Analytical Biochemistry 306:336-339.

Dong J.L., Zhang Y.W., Zhang R.H., Huang W.Z., and Zhang Y.Z. (2005). Influence of culture conditions on laccase production and isozyme patterns in the white rot fungus Trametes gallica. Journal of Basic Microbiology 45 (3): 190-198 2005.

Dumonceaux T.J., Bartholomew K.A., Charles T.C., Moukha S.M., and Archibald F.S. (1998). Cloning and sequencing of a gene encoding cellobiose dehydrogenase from Trametes versicolor. Gene 210:211-219.

Eriksson K.E.L., Blanchette R.A., and Ander A. (1990a). Morphological aspects of wood degradation by fungi and bacteria. In: Microbial and Enzymatic Degradation of Wood and Wood Components (Eriksson, K.E.L., Blanchette, R.A., Ander, A. eds.). Springer-Verlag, Berlin, pp. 1-88.

Eriksson K.E.L., Blanchette R.A., and Ander P. (1990b). Biodegradation of lignin, In: Microbial and Enzymatic Degradation of Wood and Wood Components (Eriksson K.E.L., Blanchette R.A., Ander, P. eds.), Springer-Verlag, New York, pp. 225-399

Farina J.I., Molina O.E., and Figueroa L.I.C. (2004). Formation and regeneration of protoplasts in Sclerotium rolfsii ATCC 201126. Journal of Applied Microbiology 96:254-262.

Gold M.H., and Alic M. (1993). Molecular biology of the lignin degrading basidiomycete Phanerochaete chrysosporium. Microbiological Reviews 57:605-622.

Grönqvist S., Suurnäkki A., Niku-Paavola M.L., Kruus K., Buchert J., and Viikari L. (2003). Lignocellulose processing with oxidative enzymes. In: ACS Symposium Series 855: Applications of Enzymes to Lignocellulosics (Mansfield S.D., Saddler J.N. eds.), American Chemical Society, Washington D.C. pp. 46-65.

Hofrichter M. (2002). Review: lignin conversion by manganese peroxidase (MnP). Enzyme and Microbial Technology 30:454-466.

Hoopes J.T., and Dean J.F.D. (2001). Staining electrophoretic gels for laccase and peroxidase activity using 1,8-diaminonaphthalene. Analytical Biochemistry 293:96-101. 
Johannes C., and Majcherczyk A. (2000). Laccase activity tests and laccase inhibitors. Journal of Biotechnology 78:193-199.

Johansson T., and Nyman P.O. (1993). Isozymes of lignin peroxidase and mangenese (II) peroxidase from the white rot basidiomycete Trametes versicolor. Arcihves Biochemistry and Biophysics 300(1):49-56.

Jones C.L., and Lonergan G.T. (1999). Histochemical detection of laccase in Pycnoporus cinnabarinus using microwave-enhanced colloidal gold microcrystallization. Biotechnology Techniques 13:871-875.

Leonowicz A., Matuszewska A., Luterek J., Ziegenhagen D., Wojtas-Wasilewska M., Cho N.S., Hofrichter M., and Rogalski J. (1999). Biodegradation of lignin by white rot fungi. Fungal Genetics and Biology 27:175-185.

Leonowicz A., Cho N.S., Luterek J., Wilkolazka A., Wojtas-Wasilewska M., Matuszewska A., Hofrichter M., Wesenberg D., and Rogalski J. (2001). Fungal laccase: properties and activity on lignin. Journal of Basic Microbiology 41:185-227.

Molloy C., Shepherd M.G., and Sullivan P.A. (1995). Differential extraction of Nacetylglucosaminidase and trehalase from the cell envelope of Candida albicans. Experimental Mycology 3:178-85.

Morrell J.J., and Gartner B.L. (1998). Wood as a material. In: Forest Products Biotechnology (eds: Bruce, A. and Palfreyman, J.W.), Chapter 1, pp. 1-14, Taylor and Francis Ltd., London, 1998.

Morohoshi N., Wariishi H., Muraiso C., Nagai T., and Haraguchi T. (1987). Degradation of lignin by the extracellular enzymes of Coriolus versicolor IV. Properties of three laccase fractions fractionated from the extracellular enzymes. Mokuzai Gakkaishi 33:218-225.

Nicole M., Chamberland H., Geiger J.P., Lecours N., Valero J., Rio B., and Ouellette G.B. (1992). Immunocytochemical localization of laccase L1 in wood decayed by Rigidoporus lignosus. Applied and Environmental Microbiology 58:1727-1739.

Rast D.M., Baumgartner D., Mayer C., and Hollenstein G.O. (2003). Cell wall associated enzymes in fungi. Phytochemistry 64:339-366.

Ruel K., and Joseleau J.P. (1991). Involvement of an extracellular glucan sheath during degradation of populus wood by Phanerochaete chrysosporium. Applied and Environmental Microbiology 57:374-384.

Ruel K.C., and Joseleau J.P. (2003). Development of immunomicroscopic methods for bioremediation. In: The utilization of bioremediation to reduce soil contamination: Problems and solutions (Sasek et al. eds). Kluywer Academic Publishers, Dordrecht, pp. 187-197.

Sassoon J., and Mooibroek H. (2001). A system of categorizing enzyme-cell wall associations in Agaricus bisporus, using operational criteria. Applied Microbiology and Biotechnology 56:613-622. 
Smith M., Thurston C.F., and Wood D.A. (1997). Fungal laccases: Role in delignification and possible industrial application. In: Multi-copper oxidases (Messerschmidt A. ed.), World Scientific Publishing Co. Pte. Ltd., Singapore, pp. 201-224.

Srebotnik E., and Messner K. (1998). Determination of the accessibility of lignocellulosic substrates to enzymatic degradation by immunoelectron microscopy. In: Institute of Physics Conference Series No. 93/3 Dickinson H.G., Goodhew P.J. (eds) EUREM 88. Bristol, Philadelphia:, pp 107108

Tanaka H., Itakura S., and Enoki A. (1999). Hydroyl radical generation by an extracellular lowmolecular weight substance and phenol oxidase activity during wood degradation by the white rot basidiomycete Trametes versicolor. Journal of Biotechnology 75:57-70.

Taubert J., Krings U., and Berger R.G. (2000). A comparative study on the disintegration of filamentous fungi. Journal of Microbiological Methods 42:225-232.

Tuor U., Winterhalter K., and Fiechter A. (1995). Enzymes of white rot fungi involved in lignin degradation and ecological determinants for wood decay. Journal of Biotechnology 41:1-17

Viikari L. (2003). Lignocellulose modifying enzymes for sustainable technologies In: ACS Symposium Series 855: Applications of Enzymes to Lignocellulosics (Mansfield S.D., Saddler J.N. eds.), American Chemical Society, Washington D.C. pp. 30-44.

Xiao Y.Z., Tu X.M., Wang J., Zhang M., Cheng Q., Zeng W.Y., and Shi Y.Y. (2003). Purification, molecular characterization and reactivity with aromatic compounds of a laccase from basidiomycete Trametes sp strain AH28-2. Applied Microbiology and Biotechnology 60:700-707.

Xiao Y.Z., Chen Q., Hang J., Shi Y.Y., Xiao Y.Z., Wu J., Hong Y.Z., and Wang Y.P. (2004). Selective induction, purification and characterization of a laccase isozyme from the basidiomycete Trametes sp AH28-2. Mycologia 96:26-35.

Zhu X.D., Gibbons J., Garcia-Rivera J., Casadevall A., and Williamson P.R. (2001). Laccase of Cryptococcus neoformans is a cell wall-associated virulence factor. Infection and Immunity 69:5589-5596. 



\section{Publications}

2005 Dwivedi R.C., Zomorrodi M., Kües U. and Majcherczyk A. (2005). Cell wallassociated redox enzymes in white rot fungi. In: Proc. "Genetics and Cellular Biology of Basidiomycetes VI." Pamplona, 3-6 June 2005, Spain. In press

Kilaru S., Rühl M., Saathoff A., Dwivedi R.C., Zomorrodi M., Lange K., Majcherczyk A., Hoegger P.J. and Kües U. (2005). Overexpression of laccases in Coprinopsis cinerea. In: Proc. "Genetics and Cellular Biology of Basidiomycetes VI." Pamplona, 3-6 June 2005, Spain. In press

2003 Navarro-González, M., Hoegger, P.J., Hoffmann, M., Kilaru, S., Dwivedi, R.C., Zomorrodi, M., Majcherczyk, A., Kües, U. (2003) Laccases in the dung fungus Coprinus cinereus. Fungal Genetics Newsletter, 50-Supplement. Page 68.

2005 Dwivedi R.C., Zomorrodi M., Kües U. and Majcherczyk A., Cell wall- associated redox enzymes in white rot fungi. Genetics and Cellular Biology of Basidiomycetes VI. Pamplona, 3-6 June 2005, Spain.

Kilaru S., Rühl M., Saathoff A., Dwivedi R.C., Zomorrodi M., Lange K., Majcherczyk A., Hoegger P.J. and Kües U., Overexpression of laccases in Coprinopsis cinerea. Genetics and Cellular Biology of Basidiomycetes VI. Pamplona, 3-6 June 2005, Spain.

Kilaru S., Rühl M., Saathoff A., Dwivedi R.C., Zomorrodi M., Lange K., Majcherczyk A., Hoegger P.J., Kües U., Overexpression of basidiomycetous enzymes in Coprinopsis cinerea. $23^{\text {rd }}$ Fungal Genetics Conference, 15- 20 March 2005, Asilomar, USA.

2004 Velagapudi R., Kilaru S., Hoegger P.J., Dwivedi R.C., Srivilai P., Peddireddi S., Navarro-González M., Pemmasani L.K., Zomorrodi M., Lange K., Majcherczyk A. and Kües U., Multi-gene families in the basidiomycete Coprinopsis cinerea, Gordon Research Conferences, 20-25 June 2004, Plymouth, USA.

Kilaru S., Hoegger P.J., Dwivedi R.C., Majcherczyk A., and Kües U., Ustilago maydis and Coprinopsis cinerea differ in types of multi-copper oxidase genes, 2nd International Ustilago maydis Meeting, 25-29 August 2004, Rauischholzhausen, Germany. 
Kilaru S., Dwivedi R.C., Zomorrodi M., Hoegger P. J., Majcherczyk A. and Kües U., Overexpression and characterization of 17 different Coprinopsis cinerea laccases, VAAM 2004 March 28-31, 2004. Braunschweig, Germany, p. 153

2003 Zomorrodi, M., Dwivedi, R.C., Kües, U., Majcherczyk, A., 2D-electrophoresis of native laccases from basidiomycetes, In: Conference book: Molecular biology of fungi. 6th VAAM-Conference "Molekularbiologie der Pilze" 3.-5. September 2003 Göttingen, Germany (U. Kües, ed), Wissenchaftlicher Fachverlag Dr. Peter Fleck, Langgöns (Niederkleen), Germany, p. 68

Dwivedi, R.C., Navarro-González, M., Kües, U., Majcherczyk, A., Cell wall associated redox enzymes in white rot fungi. In: Conference book: Molecular biology of fungi 6th VAAM-Conference "Molekularbiologie der Pilze" 3.-5. September 2003 Göttingen, Germany (U. Kües, ed), Wissenchaftlicher Fachverlag Dr. Peter Fleck, Langgöns (Niederkleen), Germany, pp. 67 


\section{Curriculum Vitae}

\section{Personal data}

$\begin{array}{ll}\text { Name } & \text { Ravi Chandra Dwivedi } \\ \text { Born } & \text { 15 Jan 1976, Chakhundi, Uttar Pradesh (India) } \\ \text { Marital status } & \text { Single }\end{array}$

\section{Education - School}

1992 - $1994 \quad$ B.Sc. Christian Degree College, Lucknow, India

1995 - $1997 \quad$ M.Sc. Biotechnology, Himachal Pradesh University, India

1998 - 1999 M.Tech. Biomedical engineering, Indian Institute of Technology,

Bombay, India

\section{Education -University}

1992-1994

1995-1997
Bachelor of Science, Christian Degree College, Lucknow, India

Enrollment at : Himachal Pradesh University, India:

Field of study : Biotechnology

Degree awarded : : (M.Sc) Biotechnology

M.Sc. projects

'Application of psychrophilic B-galactosidase in the commercial utilization of whey and hydrolysis of lactose in milk'

Department for Biotechnology

H.P. University Shimla, India

(Major advisor: Prof. T. C. Bhalla)

"Cloning of Glycolytic Genes"

Tata Institute of Fundamental Research (TIFR) Bombay,

(Major advisor: Prof. Z. Lobo)

Bachelor of Science, Christian Degree College, Lucknow, India

Enrollment at

: Indian Institute of Technology (IIT) Bombay, India

Field of study $\quad$ : Biomedical engineering

Degree awarded : Master of Technology (M.Tech.)

M.Tech. project

'Computer aided anti-HIV drug designing using INSIGHT-II

molecular modeling software and chemical synthesis'

Department for Biomedical engineering 
Indian Institute of Technology, Bombay, India

(Major advisor: Prof. S. V. Bhatt)

2002-2005

Enrollment at

Purpose of study

\section{: Georg-August-Universität Germany \\ : Ph.D thesis}

\section{Göttingen,}

PhD project

'Extra-cellular proteins from lignocellulose degrading basidiomycetes: Redox enzymes from Trametes versicolor and Coprinosis cinerea' Institute of Forest Botany, Department for Molecular Wood Biotechnology

(Major advisor: Prof. U. Kües)

\section{Academic achievements}

- Awarded GATE fellowship during M.Tech studies at Indian Institute of Technology. (GATE: Graduate Aptitude Test in Engineering conducted on behalf of the National Coordinating Board Department of Education, Ministry of Human Resources Development (MHRD), Government of India)

- DBT (Department of Biotechnology) scholarship during Master's in Biotechnology from Government of India 